\title{
TWENTYYEARS
}
ㄴ,
(3)
$1 \mathrm{~N}$

4) $2(10.2012$

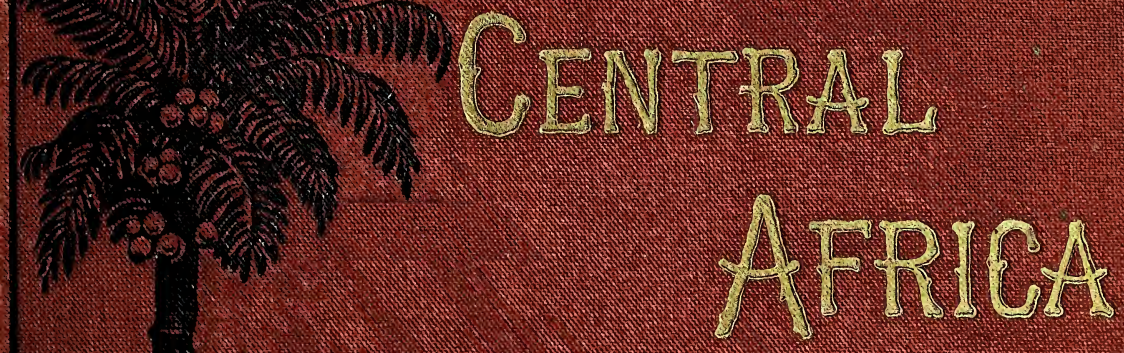

5

Af

(4)

How

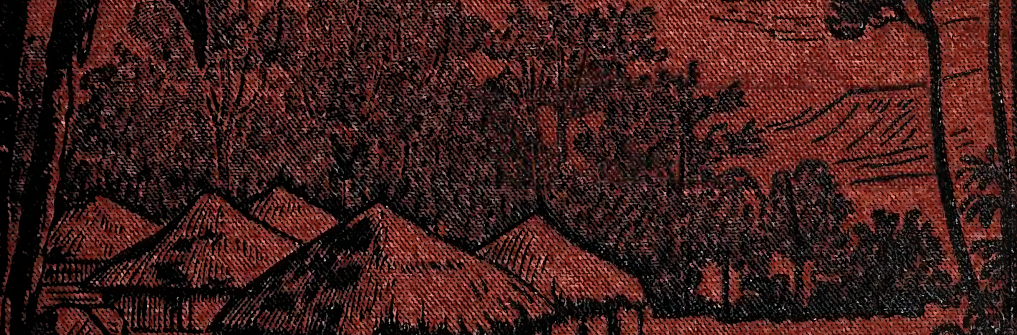

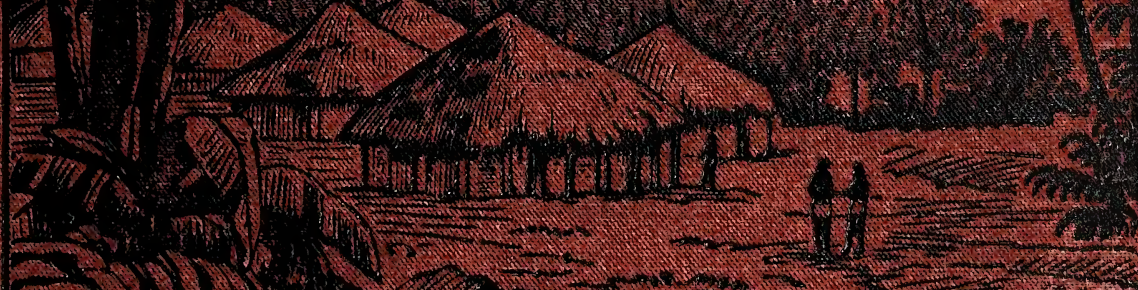

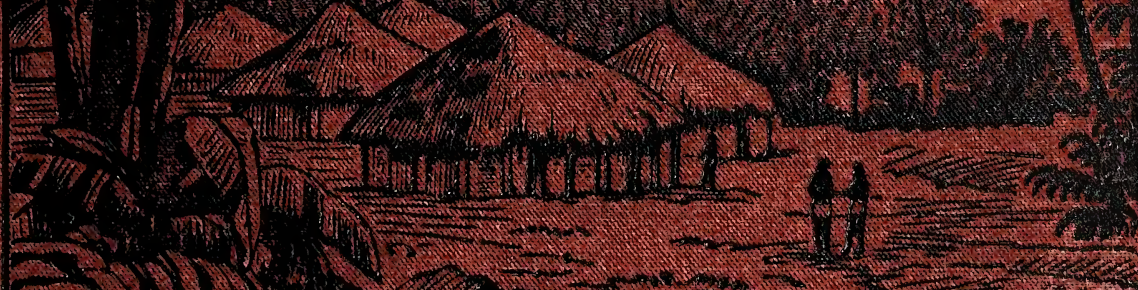

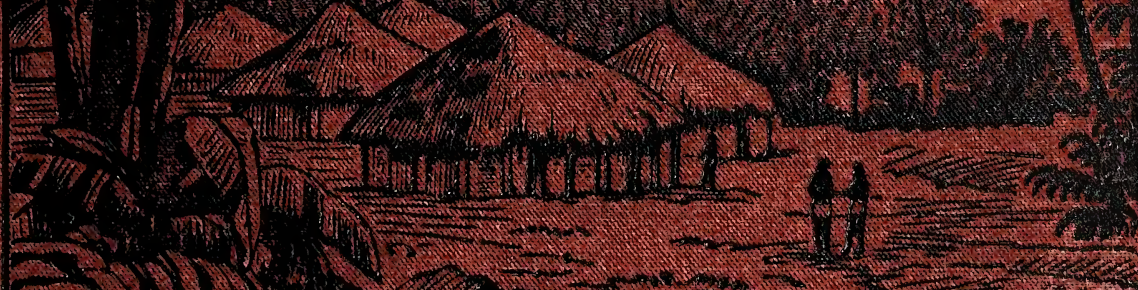

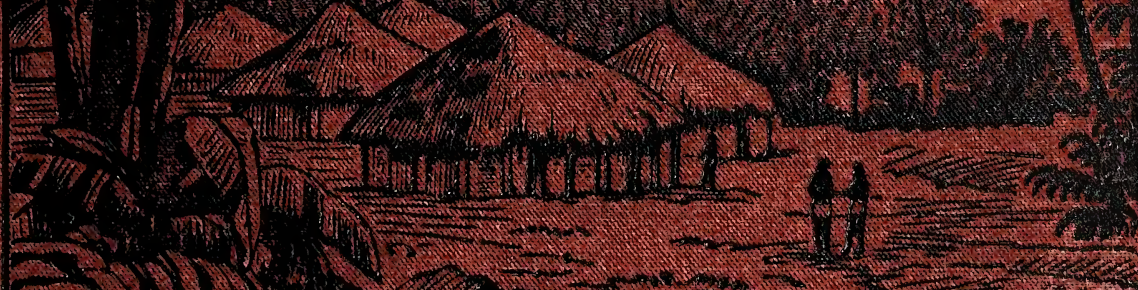

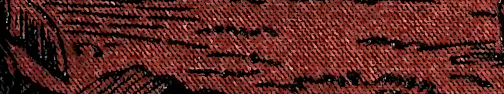

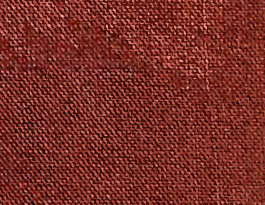

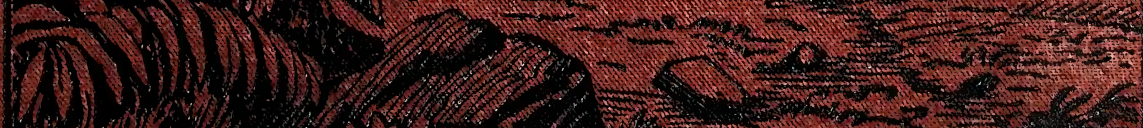


.

, 
$j$ 
4702

B 6 
$3 / 80$

Erse steven.

TWENTY YEARS IN CENTRAL AFRICA. 




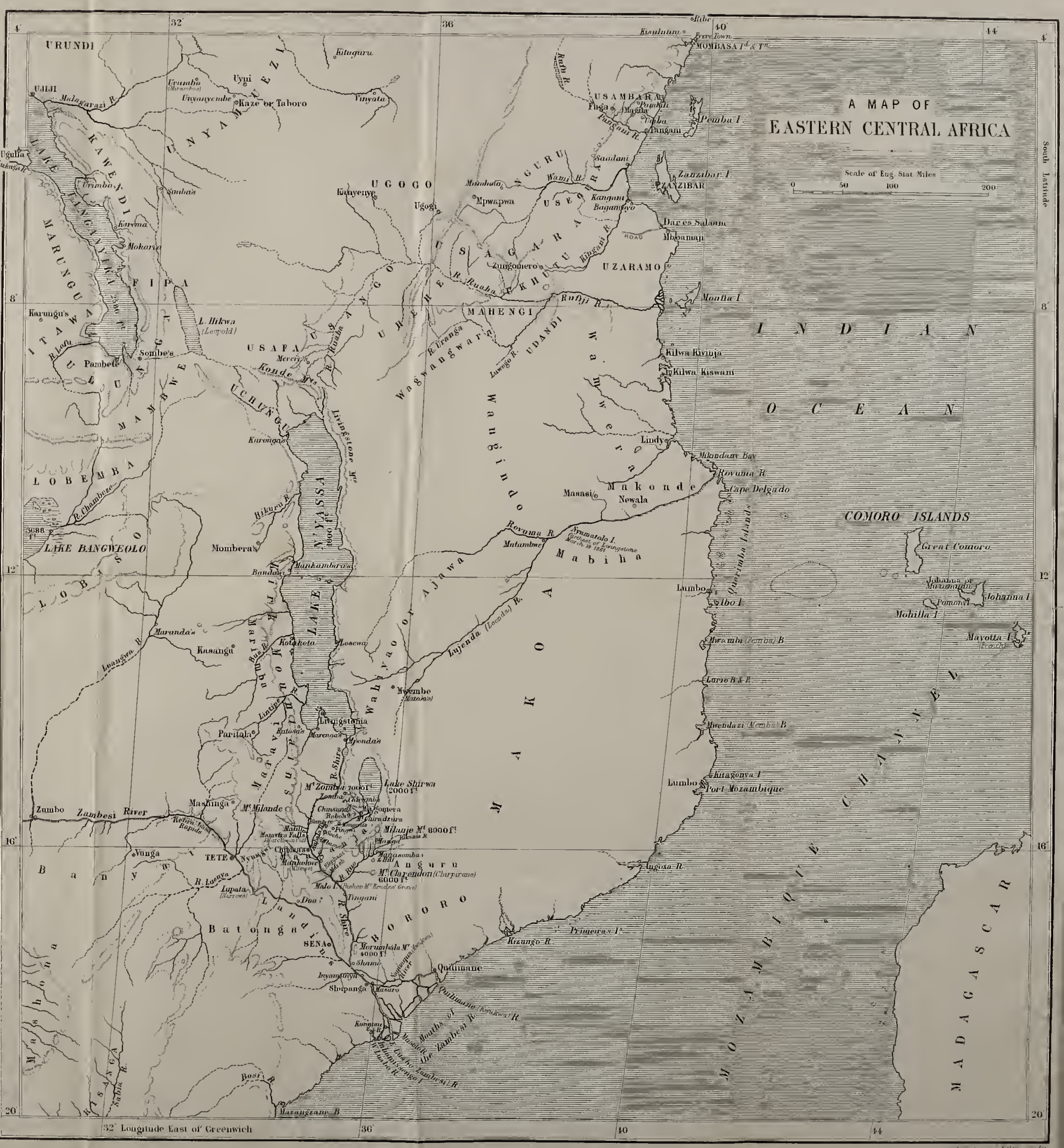

Loudou. Wells (arrduef, Darton \& Co., Patcruoster Buildings L.C. 



\section{CENTRAL AFRICA.}

BEING THE STORY OF THE UNIVERSITIES' MISSION

TO CENTRAL AFRICA,

from its Cammencement under Bistyap ftlackenţie to the

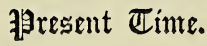

BY THE

\section{REV. HENRY ROWLEY,}

FORMERLY OF THE UNIVERSITIES' MISSION TO CENTRATAERICA ;

AUTHOR OF "AFRICA UNVEILED," "THE RELIGION OF THE AFRICAMS," ETC.

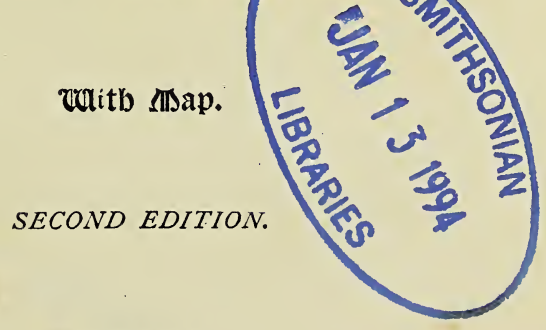

LONDON :

WELLS GARDNER, DARTON, \& CO. 2 PATERNOSTER BUILDINGS. 


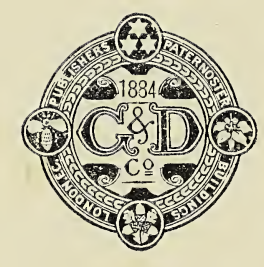




\section{PREFACE.}

"Twenty Years in Central Africa" is a revised abridgment of the "Story of the Universities' Mission to Central Africa," first published in 1866 , and a continuation of the history of the Mission up to the present year (I88I), on the basis of information mainly derived from the publications of the Mission, \&c.

The "Story of the Universities' Mission," which ended with the withdrawal of the Mission from the Zambesi, had a wide sale, and was soon out of print. I did not republish it, because as time went on, it seemed to me that, if ever it was made use of again, it should appear in an abridged form as part of a narrative comprising a much longer period in the history of the Mission than was included in it. Such a narrative appears to be needed now, and I have drawn up one here in the hope that it will prove acceptable to the numerous friends of the Mission, and to many others also.

And now, I am sorry to be obliged to call attention to a subject connected with the early history of the Mission in which I am in a special degree personally concerned.

Since the MS. of this volume was placed in the hands of the publishers, "The Personal Life of Livingstone," by Dr. Blaikie, has appeared, wherein I am accused of "unhandsome treatment" of Dr. Livingstone, of "reckless perilling of the character and interests of his expedition in order to shield others," of "blaming him for what he deprecated and for what was done in his absence," of throwing upon him "the odium of the proceedings" of the missionaries against the Ajawa, of acting indeed most unfairly, not to say dishonourably, against him (see p. 295 of "The Personal Life"). This is a grave accusation. 
Upon what is it based? Upon this : Some time after Bishop Mackenzie's death, we missionaries, to our great astonishment, received information which led us to conclude that Dr. Livingstone would condemn our proceedings against the Ajawa as being in their character different from his own, and I, with the concurrence of my brethren at the mission, wrote a letter to a friend at the Cape, in which I said: "Upon our first journey to the Highlands of this country, under Dr. Livingstone's guidance, we fell in with several slaving parties and released their captives, and in furtherance of the same object, viz., release of slaves, a somewhat desperate fight took place with a body of Ajawa who had invaded Manganja territory, and were destroying villages, and murdering and making captive the Manganja. The fear of the Ajawa was so great upon the Manganja that the districts south of Zomba were being denuded of people-the fugitives flying by hundreds. In order to give confidence to the people, Livingstone advised us to settle at Magomera. We did so, and were immediately beset by a multitude of applications from Manganja chiefs, great and small, to go against other bodies of Ajawa whose depredations were as great as those attacked under Livingstone's direction. I say ' attacked under Livingstone's direction' advisedly, because I believe he now blames us for our after-proceedings, which were but the fulfilment of his programme, the ineviable sequence of his advice and deeds.

"From the moment when he commenced the release of slaves his course was one of aggression. He hunted for slaving parties in every direction, and when he heard of the Ajawa making captives in order to sell to the slavers, he went designedly in search of them, intending to take their captives from them by force, if needful. It is true that when he came upon them he found them to be a more powerful body than he expected, and had they not fired first he might have withdrawn, but had he done so it would have been from prudence, not principle; for when searching for them his men entered into every place where they were supposed to be, firing their guns, and making every kind of warlike demonstration. 
His parting words to the chiefs assembled at Magomera just before he left, gave no evidence of the purely defensive policy he, I believe, now claims for himself. Speaking of himself and us, he said to this effect :- 'You have hitherto seen us only as fighting men, but it is not in such a character we wish you to know us. My brothers, who will remain at Magomera, wish to teach you about the great God, the Good Father of us all, and they will make Magomera a strong place to which those who are afraid may fly. I do not think the Ajawa will again trouble you; the lesson we have given them will keep them quiet, but should they do as they have done, I shall be up here again soon, and then they must be looked after once more." "

I here give the whole of the passages relating to Dr. Livingstone's proceedings on the occasions referred to, because my object in writing will thus more clearly appear than in the fragments from my letter which Dr. Blaikie produces.

Now this letter was not written to throw upon Livingstone "the odium" of our proceedings, nor to blame him "for what he deprecated," nor to make him responsible for what we missionaries had done, nor to screen ourselves by accusing him, nor to say that "all that the Bishop had done was done by his advice," as Dr. Blaikie affirms ; but to inform my friend and other friends at the Cape who were interested in the Mission, that between what Livingstone did and what we did there was really no difference ; that he took the offensive against the slave-dealers and the Ajawa in league with them as certainly as we, and that his proceedings were, in their character and object, identical with our own.

Dr. Blaikie's treatment of this subject is calculated to lead his readers to the conclusion that I wrote this letter in order to give public expression to the unworthy feelings with which he credits me, but he must have known that this was not the case, for he quotes a passage from another letter of mine which appears in " The Zambesi and its Tributaries," and which Livingstone prefaces by saying that the Cape Town letter was a private note, and not intended for publication. That letter would never have been published, had not a letter from Dr. I.iving- 
stone to Sir Thomas Maclear appeared in the Cape papers, in which he blamed us for our proceedings against the Ajawa, but said nothing of his own encounter with them. This so provoked my friend that he sent my letter also to the Cape papers, from which it was copied into the Times for Nov. 26, I 862.

Considering all the circumstances of the case, I was quite justified in writing as I did,-supposing what I said was true. I saw Dr. Livingstone in Africa after he had become acquainted with my letter, and he did not question its accuracy, nor did any of his companions who were associated with him in the transactions to which it refers. Dr. Blaikie himself does not venture to say in so many words that it is not true, but he writes about it as though it were a gross misrepresentation of the real facts of the case, and he supports himself in so doing by a statement that my letter was so far from expressing the mind of my brother missionaries that some of them endeavoured to persuade me to write to the Cape papers that it conveyed a wrong impression, a statement for which there is no foundation in fact; and he also produces a letter from Livingstone to Sir Thomas Maclear, which says :- "It is untrue that I ever in any occasion adopted an aggressive policy against the Ajawa, or took slaves from them. Slaves were taken from the Portuguese alone. I never hunted the Ajawa, or took the part of the Manganja against the Ajawa. In this, I believe, every member of the mission will support my assertion."

This letter seemingly contradicts what I had said; but it must be observed that I nowhere charge Dr. Livingstone with assuming an aggressive attitude against the Ajawa tribe as such, my letter is solely concerned with his action against the Portuguese slave-dealers and that section of the Ajawa who were in league with them, and who were to all intents and purposes slavers themselves. This action was directed solely against the slave-traders and their coadjutors, and against them he certainly did proceed in the manner $I$ have described in my letter, and in this volume (see page $4 \mathrm{I}$ and onwards). Witnesses to the truth of this are not wanting. Mr. Waller was engaged in these very transactions; he kept a record of 
them, and his Journal, which was published in the Report of the Mission for I 862, confirms all that I have said. I pass by his description of the encounters with the Portuguese slavedealers, for they are not questioned, and transcribe his account of the conflict with the Ajawa.

"Tuesday, July 23. Started at 9.30 from Maroongwi's for the Achawas, encamped, we heard, within an easy distance. We went along briskly till about $\mathrm{I} 2$, when the traces of the marauders became thicker and thicker. Village after village was passed, plundered and burned; the poor inhabitants were enabled to escape, being scattered about, crouching in the long grass by the pathway, with their baskets of corn hastily snatched up. ... O Of a sudden we came in sight of two large columns of smoke rising from the plain, and were told that they were two burning villages set on fire this very morning; nor did it take long to confirm this. The Bishop now offered up a short prayer for our guidance, and then we moved rapidly in that which seemed the last set fire to. We passed through it quite empty, a perfect picture of desolation. Immediately after we turned sharp to the right, and passed over some rocks and through the burning grass; the loud wailing of women away on our right ringing in our ears continually. Of a sudden we spied in the distance a long line of people walking at right angles to us, with heavily-laden baskets of corn and booty on their heads. We hardly knew whether to put them down as Achawas or fugitives, though there was not much doubt. As we neared them they evidently became uneasy, though we hid our arms from sight. The line came to a halt when we were within a quarter of a mile of it, and one of their chiefs stood upon a stone to hail us, taking us for slave-buyers, I think, by his manner. Unfortunately some of our men (they were Makololo armed with guns) made a rush at him before the Doctor could open a parley, and he bolted instantly, spreading the alarm, which sped along the hills from mouth to mouth towards their camp, which was situated some mile and a half to the left of the spot, they being in direct march for it when we came across them. 'Kondo, kondo,' and a horrid 'Loo- 
loo-loo,' repeated as fast as possible, is their cry-the first meaning 'There is war, there is war!' Numbers of poor refugees joined our train, and showed us where the camp was. We went down a very steep declivity, the ground strewn with immense quantities of all sorts of booty, which they had thrown away in their precipitate bolt. One thing I think is worthy of mention: a good half-mile before we came upon them I distinctly saw flocks of small birds and some crows hovering round those bearing the corn, \&c., as if they were used to the doings of the party, and accompanied them, as the jackals do the tiger.

"We now ascended another steep hill, and on its summit found the confines of a large, widely-spread camp. To describe the position is difficult ; suffice it to say, it was on the crown of a hill broken in places by large stone cairns, and surrounded on the three sides by gorges-in fact, unapproachable to native warfare; and, but for the surprise we took it with, well-nigh impregnable to us. A better-chosen place could not have been; it gave one the most complete notion of a mountain stronghold, and was, besides, in the pass that led to the Shire plain below. At a guess there were about seventy huts spread about upon it. The Doctor called out, as we ascended the hill, that we wanted to speak to them; but they insisted it was 'War, war!' As we went on to the hills, they set themselves in their battle order, which consists in concealing themselves at bow-shot in the long grass or behind stones. They fired on us, and the fight began. We advanced quietly to their main position, they retiring before our guns; but, all things considered, they fought bravely. After going to the extreme end, thinking we might find slaves, but not doing so, and not being able to drive them out of the place with our small numbers and badly-supplied ammunition-cases, we turned to come back by the way we came in. This they took for a retreat; so we faced about and drove every soul out of the village, and off the farther small hill, setting fire to the place and reducing it to ashes, with the exception of some outlying huts, in a few minutes. 
"After this we determined to go down into the Shire valley, skirt the foot of the range we were on, and ascend it again farther to the south. The enemy kept up a constant fire from their muskets, of which they had several, and in descending the hill one poor fellow got shot in the leg and was instantly murdered by the Achawas. (He was a Manganja man.) Several on their side were killed, I believe."

It is pitiful in the face of the above narrative to find Dr. Blaikie saying :- " Livingstone declined to write a contradiction (of Mr. Rowley's letter) to the public prints, because he knew the harm that would be done by a charge against a clergyman. In this he showed the same magnanimity and high Christian self-denial which he had shown when he left Mabotsa." ("Personal Life," page 296.) What was there to charge me with? To suit their own purposes, some friends, and some who were not friends of Livingstone, made an unfair use of my letter, but no one has ventured to deny its truthfulness.

There is, however, one phrase which, wrested from its context, might seem to support Dr. Blaikie's insinuation that I said that it was by Dr. Livingstone's advice that we attacked the Ajawa; for I do say that our proceedings against them were "the inevitable sequence of his advice and deeds." And so they were : for had he not gone against the Ajawa and advised us to settle at Magomera, within sight and sound, as it were, of their murderous proceedings, I doubt if we should have taken action against them; but being where we were, and also in antagonism with them in consequence of what he had done, we felt that we could not act otherwise than we did. This is what I meant, and I think my meaning was sufficiently apparent.

I really am very sorry to be obliged to make these explanations, and Dr. Blaikie was most ill-advised to force me to do so, for in justice to myself and others, he could scarcely expect me to keep silence under his accusations. His action also, in this matter, is quite unnecessary, for whatever misapprehension may have existed concerning the intention and truth of my letter, it had been disposed of by Dr. Livingstone himself when he published, without contradiction or explanation, a 
letter to himself in the "Zambesi and its Tributaries," page 475, wherein, after defending him against Mr. Lacerda, a gentleman who, in the interests of the Portuguese, accused him of causing the misfortunes of the Mission by his attack upon the Ajawa, I say:- "I always said and thought that you did well in releasing the slaves, and in going against the Ajawa under the idea that they were a mere slaving horde. My letter to Mr. Glover was not written to blame you for what you had done, nor to throw the responsibility of our acts upon you, but to make known to our friends at the Cape that you had done what we had done, and that you were the first to do it."

But Dr. Blaikie appears to think that in order to exalt Livingstone it is necessary to depreciate somebody else, so he ignores the above explanation altogether, though perfectly aware of its existence. He ought not to have done this. It is unworthy of himself, and most unworthy of his subject.

No one has a higher appreciation of Dr. Livingstone's life and work than I have; he did great things from highest motives; and by what he did he inspired, and still inspires, other men to attempt great things. His action against the slave-traders and the Ajawa marauders was one of the noblest things he ever did; and by it he dealt a deadly blow to the slave-trade on the Shire Highlands, and gave to Englishmen, whether missionaries or travellers, a higher position in the land than they wonld otherwise have held.

H. ROWLEY 


\section{TWENTY YEARS IN CENTRAL AFRICA.}

\section{CHAPTER I.}

I $\mathrm{N}$ I857 Dr. Livingstone, who had not long before returned 1 from Africa, appealed to the Church of England at Cambridge and at Oxford to enter upon the mission-field which his discoveries in Africa had opened up. And he did not appeal in vain ; for a mission now known as the Universities' Mission to Central Africa was founded, As originally constituted, the mission had a twofold object in view-(r.) To raise the natives into spiritual fellowship with ourselves by the preaching of the gospel. (2.) To raise them in the scale of civilisation by the encouragement of agriculture and a lawful commerce, and the ultimate extinction of the slave-trade.

Charles Frederick Mackenzie, then Archdeacon of Natal, was chosen to be the Bishop of the mission; several clergymen volunteered to go with him; the aid of several laymen was also secured; the support of the general public was gained; and no similar enterprise in modern times excited greater hopes of success.

For some time, however, much difficulty was felt with reference to the best locality for the mission. But in 1858 Dr. Livingstone, who had returned to Africa, in the course of his explorations discovered a portion of the highland region which was easily reached from the sea by the aid of the Zambesi and 
Shire rivers, and the descriptions which he and his companions gave of it influenced the promoters of the mission in its favour.

Hitherto so easy an access to the healthy highland regions of Central Africa had not been imagined, and so promising a mission-field had scarcely been hoped for. Of the Zambesi, as the future highway for religion and commerce, great expectations had already been raised; but the Shire, which takes its rise in Lake Nyassa, and enters the Zambesi at about I 50 miles from the coast, was said to be far superior to the Zambesi for steam-navigation, being deep and free from sandbanks, and consequently navigable throughout the year. The valley of the Shire was reported to be of boundless fertility, and characterised as the future rice and cotton field for the world. The Shire highlands were described as a magnificent and healthy country, from three to four thousand feet above the level of the sea, well watered, abundantly wooded, admirably adapted for cattle and sheep, with a rich soil, and already growing cotton largely. The natives were said to be brave, industrious, and friendly. Added to all this, the much-dreaded African fever was, it was asserted, fairly met and overcome by a happy combination of medicines, which rendered it not much more harmful than an ordinary cold in England.

It would have been strange indeed if great hopes had not been raised by such good news. Men of all habits of mind began to regard the mission as practicable, and the Times honoured it with its approval.

On October 2 nd, 1860 , a service of farewell to the missionaries was held in Canterbury Cathedral, and four days afterwards Archdeacon Mackenzie, the Rev. L. J. Procter, the Rev. H. C. Scudamore, Mr. Horace Waller, S. A. Gamble, carpenter, A. Adams, agriculturist, and Johnson, a man of colour, who had been a slave in the United States of America, left Plymouth for Cape Town, where the consecration of the Archdeacon was to take place. It was arranged that I should leave England by the November mail, but through a misunderstanding with the shipping agents I could not get away until December. Other members of the mission were to follow in the course of a few months; and so lightly were the difficulties that would have to 
be encountered estimated - and according to the information received from Dr. Livingstone this estimate was not unwarranted-it was further determined that the Archdeacon's sisters and other ladies should join the mission as soon as a settlement had been made.

Archdeacon Mackenzie was consecrated at Cape Town on January I, I86I. I arrived there a few days afterwards, and found that the mission party, which had been increased by the addition of some Christianised Africans, natives of the region to which the mission was going, had departed. The greater part had gone on a fortnight before in H.M.S. Sidon, which had in tow the Pioneer, the steamship sent out by the Government to Dr. Livingstone ; but the Bishop, the Rev. L. J. Procter, and two of our African allies, had left in H.M.S. Lyra only the night before I arrived, purposing to stay a few days at Natal, and there I was able to join them.

Upon leaving Natal, the Lyra made for the Zambesi, which she reached on February 7 th, and where she found the Sidon awaiting her arrival. Those of the mission party that had come up in the Sidon had gone into the river with the Pioneer several days before, and the weather having been unfavourable for the passage of the bar, which no boat can cross save under very favourable circumstances without danger of being capsized, there had been no communication with them since.

Captain Oldfield waited until the evening of the 9th, in the hope that the Pioneer would come out, but as she showed no disposition to move, he offered to take the Bishop into the river in his gig, knowing that he was anxious for news of Dr. Livingstone. We watched the departure of the little boat, and with some anxiety saw it approach the breakers, furl its tiny sail, and pass out of sight; but a few minutes afterwards a white flag fluttered from the flag-staff on shore, and we then knew that all danger had been safely passed.

Captain Oldfield and the Bishop returned on the evening of the I Ith, and reported that Dr. Livingstone, Mr. Charles Livingstone, Dr. Kirk, and sixteen Makololo, natives that had been brought from the interior, were on shore, and that the missionaries were with them in good health and spirits. 
Livingstone had been waiting at the Kongone, as this mouth of the Zambesi is called, since January ist. He had expected the Pioneer sooner, but the missionaries not so soon, for he put into the Bishop's hands a letter which he was about to send to England to him.

To his surprise, the Bishop discovered that Livingstone was unwilling to forward the mission to its destination by way of the Zambesi and Shire, as he now thought that a better route might be found by way of the Rovuma, a river $45^{\circ}$ miles north of the Zambesi, which was supposed to take its rise in the neighbourhood of the Lake Nyassa, but of which little was really known.

On the morning of the $\mathrm{I} 2 \mathrm{th}$ the Pioneer left the river, and Dr. Livingstone, who came on board the Lyra, gave his reasons for thinking that it would be better for the mission to go into the country by way of the Rovuma rather than by way of the Zambesi and Shire. Briefly they were these :-

I. The influence of the Portuguese, who claimed the coastline from Delagoa Bay to Cape Delgado, and had towns and villages far inland along the Zambesi, would be used against the mission, as they were largely engaged in the slave-trade; whereas the Rovuma was beyond their possessions, and would leave us free to carry out our plans without being opposed by them.

2. The difficulty of transporting stores from the Shire was great; a large amount of native labour would be needed, and could not be had, as Chibisa, the only friendly chief, had left the Shire, and the rest of the chiefs would do nothing.

3. The mission was without a medical man; the season was unhealthy; he, Dr. Livingstone, could not stay with the missionaries, and fatal consequences would probably ensue.

The Bishop was not convinced that it would be better for the mission to wait while an unknown river was explored, than to proceed without delay by way of rivers that were known; and he gave his reasons for thinking that the delay in commencing work might prove more injurious to the mission than anything the Doctor had mentioned. Dr. Livingstone, however, would not give way, and he proposed that with the 
exception of the Bishop and one other, who might accompany him, the missionaries should proceed to the island of Johanna, where they might be profitably employed, and there await the result of the exploration of the Rovuma. He promised that if the Rovuma did not answer to his expectations of it, he would take the mission to the Shire highlands by the way he originally proposed. The Bishop could do no other than accept Dr. Livingstone's proposals ; for as he was ignorant at that time of the assistance which the Portuguese could and would, as events showed, not unwillingly give, it seemed that the mission was entirely dependent on the Doctor for the means of getting to its destination.

The Pioneer then went on to the Rovuma, the Lyra and the Sidon to Johanna, from whence it was arranged that the Lyra should take the Bishop and myself to the Rovuma.

The Lyra arrived at Johanna on the 2 ist. Like all of the Comoros, this island is of volcanic formation, a mountain heaved up from the depths of the ocean. It is in the region of perpetual summer, and is covered from its base to its summit, 6000 feet high, with a never-failing beautiful verdure. Its area is about $25^{\circ}$ square miles, and it is governed by an Arab king, who belongs to the same race that has given to these parts most of its petty sovereigns. The population was then about Io, ০oo, of whom three-fourths were African slaves.

The Lyra made for Pomoney, the residence and plantation of Mr. Sunley, the British Consul for the Comoros, by whose aid it was hoped, and not in vain, that accommodation would be found for the missionaries who were to stay on the island.

It had been the intention of Captain Oldfield to remain but a few hours at Johanna, and then to make directly for the Rovuma; but news having arrived at Johanna that H.M.S Wasp had gone ashore on the coast just below Cape Delgado, and that the Enchantress, a ship laden with stores for the East Coast Squadron, had run on to the coral reef at Mayotte, another of the Comoros, he resolved to go to the assistance of these ships before taking us to the Rovuma ; and thus it came to pass that the Lyra did not arrive at the Rovuma until the afternoon of March 9 th. 
The Pioneer had arrived twelve days before, and was preparing to ascend the river without further delay.

The next day being Sunday, we remained at anchor, but on the morning of the IIth, the Bishop and I left the Lyra for the Pioneer-Captain Oldfield, Lieutenant De Wahl, and Mr. Paymaster Jones accompanying us. As soon as we were on board, the anchor of the Pioneer was lifted, and the ascent of the river began.

The mouth of the Rovuma forms a noble bay, and entrance to the river is unobstructed by a bar. For a few miles the river is both broad and deep, then it rapidly shallows. The Pioneer halted for the night at about ten miles from the sea. The mangrove swamps were left far behind, the valley was flanked with thickly wooded hills, and bold mountain-land was to be seen in the distance. We had passed on our way hippopotami and crocodiles, with great numbers of flamingoes and pelicans, herons and cranes, black and white ibises, and many other sorts of birds.

Our progress up the river on the I 2 th was slow, for sandbanks were numerous, and much difficulty was experienced in finding the channel. But the difficulties of this day were exceeded by those of the next; for though under steam for many hours, the Pioneer made no more than four or five miles.

Next morning Captain Oldfield and his officers bade us farewell. Before going, however, the Captain expressed his conviction that the Pioneer would not get twenty miles farther up the river, and said he hoped that it would not be found impossible to bring her down again before the next flood season.

The possibility of this naturally made the Bishop feel anxious. To Dr. Livingstone the delay of his ship in the river for a few months would not be a great inconvenience, as he would be doing his own proper work in making land journeys up to and about the Lake Nyassa; but to the mission such a delay was likely to prove most injurious.

We weighed anchor on the 15 th immediately after Captain Oldfield's departure; but we were soon in a very labyrinth of 
sandbanks, and the higher we got the more difficult the navigation became.

During the day an incident occurred, which, as an illustration of the character of the people on this part of the river, is worth recording. Firewood being needed, the Makololo went ashore to get it. They had not been long at work, before a number of men appeared, armed, for the most part, with guns, but carrying on their heads pumpkins, melons, and other kinds of vegetables for sale. Their leader, a half-caste Arab, began to talk insolently, saying the country was his and the trees his, and that wood should not be cut unless it was paid for. Mr. C. Livingstone, who was on shore, told him that for things to eat we would pay, but for wood to burn no pay would be given, such a thing being unheard of before. Whereupon the man began to threaten, and to lay hands on the wood that was cut; but Mr. C. Livingstone sent some of the Makololo for his revolver and their muskets. When they returned, without further parley, they made a dash at the malcontents, who ran off as fast as they could, leaving behind them in their fright the things that they had brought for sale. But they did not remain long absent; for finding that they were not pursued, they came back again, but no more attempted to dispute our right to cut wood for fuel. Their fruit and vegetables were bought, and they were informed that if any harm came to them from us, it would be their own fault, as we wished to be friends.

Before leaving, the chief man reassumed something of his old bearing before his followers, and assured them that had he chosen to fight, he could have done great things, for his gun would go off. The Makololo heard his boasting, and laughed at him so provokingly, that he was glad to get away from their ridicule.

From midday to sunset the weather was stormy. There was heavy rain and much thunder. The sunset was past description beautiful. Such a glorious manifestation of colour is rarely seen out of the tropics. When the rain ceased the temperature was delightful. The sweet influence of the hour seemed to be sufficient to satisfy all desires. But the Bishop, 
while watching the ever-changing glories around the setting sun, began to sing-

$$
\text { "Jerusalem the Golden." }
$$

Then the Makololo came up to him, and asked him to sing again, so we both sung Keble's "Evening Hymn," and

\section{"Father, by Thy love and power \\ Comes again the evening hour."}

Then Dr. Livingstone told Moloko, the principal man amongst the Makololo, to sing, and he sang a song composed by his great chief, Sebituane. The melody was like to that of an old Latin hymn-tune, and set to sacred words it might have passed as such. When Dr. Livingstone first heard this song, Sebituane was dying, and hundreds of his chosen warriors sang it, at his request, while seated around his hut.

Our progress next day was not great. The Pioneer was under steam early, but after five or six hours of heavy work, no more than five or six miles had been accomplished. On the day following the Pioneer remained at anchor, and it being reported that there was a native village not far off, the Doctor took us for a stroll in search of it. We had not proceeded far before we came up to a native, armed with a bow and arrows, who had evidently been watching us. Dr. Livingstone did not understand his dialect, but a man he had with him did; and upon being informed that we wished to go to his home, he without hesitation led the way. It was, he said, near. But the word "near" has a relative meaning in Africa. In England, if told that a place is near, in the same way as if you were informed that a house you wished to go to was only just round the corner, you would not expect to have to walk five miles before you came to your destination. In Africa, however, it is otherwise: a man pokes out his chin to intimate that the distance you have to go is really nothing, but it will frequently take you at least two hours to traverse it. It was so in this instance.

There were but seventeen huts in the village, and they were in a ruinous condition. We seated ourselves under the shade of a large tree, and our guide stood before us, evidently in an 
uneasy state of mind as to our motives. No other people were to be seen. We asked him for water, and he declared that there was none to be had; but upon the Doctor giving him a hearty slap on the back, and an assurance that we meant no harm, he ran off laughing, and presently returned with a jar of water, followed by several other men, who sat down in front of us, and finally some women and children came from their hiding-places. The children were of prepossessing appearance, but the women were simply hideous. Their heads were shaven as bald as the palm of the hand, and they wore in an aperture in their upper lip a circular block of wood fully two inches in diameter. A similar custom prevails amongst the women of almost all the tribes in the Nyassa lake regions, though in some places instead of the block they wear rings like a tablenapkin ring, made of the wood of the castor-oil plant. The effect of this custom is frightful, and it is a fashion as inconvenient as it is ugly. The women cannot pronounce properly many of the words of their own language; eating and drinking are not easy of accomplishment; and though the mothers have as much affection for their little ones as mothers have in more civilised parts of the world, they cannot manifest that affection as such mothers do, for with the pileli or lipring standing out at right angles to the teeth, kissing is impossible. It was a long time before I could without disgust look at the faces of women thus outraged.

There was no sign of food in the village, no bleating goat or cackling fowl. The people were evidently oppressed and in great poverty. And yet the land was fertile, and capable of growing food for twenty times the population it then sustained.

Nipa was the name of the head man of the village, but, with true African policy, Nipa kept away from us. We expressed our desire of seeing him, and the man who had acted as our guide went off to fetch him, but he returned saying that he was not to be found, and brought us a large melon instead. While refreshing ourselves with this, an Arab, accompanied by a tall emaciated African, his slave, came into the village. Upon seeing us he hesitated, but the Doctor bade him come forward and fear nothing; so pushing the natives on one side, and 
taking the mat they were using, he sat down before us. The way in which this was done, and the effect this man's presence had on the villagers, showed clearly enough their relative positions. These half-caste Arabs are the tyrants of the natives in these districts, and it is owing to their exactions and proceedings that the population is so thin and poor. This fellow did not stay long, and when he went away he wished that Allah might be with us, but from the expression of his face and the harshness of his voice, this wish seemed to partake more of the character of a curse than a blessing.

Dr. Livingstone's object in visiting this village was get information, and he learnt that the country was called Chiungura, that the name of the supreme chief was Doni, and that the Rovuma would soon be so shallow that the water would nowhere be deeper than a man's middle.

On the Igth it became evident to all that we had gone up the river as far as we could go without the risk of being stranded for months, The water was falling so rapidly that it decreased seven inches on that day; and the question was, should we go on or at once return?

It was considered also that the mission could make no suitable settlement where we were, for though the country was attractive, it was thought to be too near to the coast, and too much under the influence of the half-caste Arabs to answer our purpose. But Dr. Livingstone imagined that we might force our way much farther up the river, and suggested that when we had got as far as we could go, the Bishop and I might stay and do what we could amongst the people as missionaries, whilst he and his party proceeded overland to Lake Nyassa. Their return, it was thought, would be simultaneous with the next rise of the river in six months. If the overland route was found practicable, and the country and people favourable, we might then have the rest of our party and stores brought over from Johanna, and with our whole force go up to the lake region by way of the Rovuma.

This plan, from our point of view, was open to grave objec. tions, and we stated them.

Other plans were proposed, to which we could not object, but which did not satisfy us; and the Bishop was much 
troubled by the unfavourable position in which the mission was placed through Dr. Livingstone's departure from his original proposal.

Our presence undoubtedly embarrassed him. He had long been waiting for increased means to carry out his work, and now that he had them, he was naturally anxious to use them. $\mathrm{He}$ had also to consult the feelings of those who were associated with him, men whose interests were bound up with the success of the expedition, and who could not be supposed to be willing to risk that for the sake of the mission. Nevertheless, the Bishop could not help feeling that Dr. Livingstone was largely responsible for the welfare of the mission, since it was owing to his invitations, representations, and promises that we had come out, and that it was his duty, therefore, to do what was best for it, even though he had to defer his own plans. And when the subject was finally discussed, he himself took this view of the position, and said:- "I am anxious to do the best that can be done for Africa, and, taking all things into consideration, I think the best thing that can now be done is to get the mission established as quickly as possible, and to do that well we had better not divide our forces. We will go down the river to-morrow, and return to the Zambesi all together."

The going down to the sea was not easy. We were continually aground, and more than once it seemed as though we should be hopelessly stranded; but after four days of heavy labour the ship was once more anchored at the mouth of the river.

Thus ended this attempt upon the Rovuma. It was a great disappointment; but the novelty of the position, the glorious climate, the beauty of the scenery, and the strange conditions of life which we had seen, had made it to me a most enjoyable experience. There had not been a sign of sickness amongst us; the unhealthiness of African rivers seemed to be a fable; I never had better health or larger appetite.

But this happy state of things did not continue. We had not been more than a few hours at the river's mouth before a sailor sickened with fever. Then the Bishop was attacked, 
then Dr. Livingstone, and one after another fell ill from the same cause, until, of the Europeans on board, I alone escaped. The fever did not affect all alike. Some had it severely, others but slightly; some lingered in it for many days, while others recovered in a day or two. So many were down at one time that our departure from the river was delayed until the 2 th (Good Friday), and then not sufficient men had recovered to work the ship in case of severe weather; but it was thought to be more perilous to wait where we were than to put to sea; and the engineer being convalescent, we got up steam and stood towards Johanna.

Our progress was slow, for having but one engineer fit for work, we could not steam at night, and the Pioneer sailed badly. All who were able had to help in working the ship, to take the helm by turns, to keep watch, and do anything else that was necessary.

We sighted the island of Comoro early in the morning of April 2nd, but we made for Mohilla, the smallest and the most beautiful of the Comoros, and about midday cast anchor close to the island, just opposite to a pleasant-looking village. We were then reduced to our last sack of coals, and we had scarcely a gallon of fresh water left, for by an oversight the tanks had not been filled in the Rovuma. A man who wore a turban and a handsome robe came off to us, and in broken English wanted to know who we were, where we had come from, and where we were going to. We satisfied him on these points, and then made known our wants, water and wood, fresh meat and vegetables; and finding that our wants could be abundantly supplied, and that the island was a pleasant place to rest at, Livingstone resolved to stay several days at Mohilla, for the sake of the fever-smitten, and for the refreshment of those who were convalescent.

When we started again, a few hours' steaming brought us to Johanna. We went first of all to Pomoney, where we learnt that our brethren had gone to the other side of the island. The Bishop and Dr. Kirk resolved to walk across to them. I kept to the Pioneer. The news of our arrival preceded us, and when we anchored off Muzumudu, the capital, Captain Stirling, 
the commander of the Wasp, who had brought his ship to Johanna, and was awaiting orders, came off to us, bringing Mr. Waller with him, from whom we obtained more particular information concerning the mission party.

After we left Johanna for the Rovuma, the missionaries had stayed for a few days on board the storeship, then had gone round to Muzumudu, and occupied the disused consulate, which Mr. Sunley had kindly prepared for them, where they had been attacked with fever. But all were now fairly well, and were living in some cottages belonging to Mr. Sunley, on the top of a hill nearly a thousand feet above the sea. The Bishop and Dr. Kirk arrived there before we did, though the former was suffering from another attack of fever, which came on during his walk, so that he had some difficulty in reaching his destination.

At evening-prayer the whole mission staff met together for the first time.

Our stay at Johanna lasted longer than we expected, for several members of the expedition were far from well, and the crew of the Wasp was suffering so much from fever and other illnesses, brought on by exposure and hard work while the ship was ashore, that it was deemed advisable for Dr. Kirk to attend the sick for a few days.

The Wasp supplied the Pioneer with sufficient coal to steam across to the Zambesi and to carry her past the woodless districts. But after this coal was got on board, it was clear that little else could be taken; and Dr. Livingstone informed the Bishop that we must leave at least two-thirds of our stores and material at Johanna. This was a grave matter; for there was now no possibility of getting any other conveyance to the Zambesi, and what we had provided for ourselves we should doubtless want, as our stores had been selected at the Cape by those best informed on the subject of our probable necessities for the first year. Truly the expedition to the Rovuma was proving a most unfortunate venture for the mission. Had we gone up the Zambesi in February, we would have taken all our stores with us, for then there would have been no need of the coal which now encumbered the decks of the Pioneer and half 
filled her hold. Dr. Livingstone, however, assured us that he should have no difficulty in bringing up our second year's stores from the mouth of the Zambesi, and advised the Bishop to send for his sisters, and promised to bring them up the river to him. So we followed the good Bishop's example, and did not aggravate our difficulties by dwelling unduly upon them. It was in such emergencies as these that the grand features in his character shone out. His faith, and hope, and charity were inexhaustible. It was good to be with him, for he had the rare gift of making others rise superior to themselves.

We left Johanna for the Zambesi on Monday, April 22d. The Pioneer was then laden to within an inch or two of what she could safely carry in smooth water. The change of the monsoon was imminent. The officer who had hitherto commanded the Pioneer had resigned his charge, and Dr. Livingstone acted as captain. It was a bold thing for a man to do whose knowledge of navigation was so limited as his; and so the professional commanders seemed to think, for when we bade them farewell, they gave their shoulders a significant shrug as they wished us a safe voyage.

Our position was not a pleasant one certainly. Fever was not expelled from the ship, and that was not to be wondered at. There was healthy accommodation for twenty people on board the Pioneer, but she carried forty-eight. The deck was blocked up with boxes, bales, and sacks of coals. The saloon and after-cabin were offensive with the bad odours proceeding from the mass of stuff that was stored in them. For three days, when unwell and unable to remain on deck, I had a berth in the saloon, where my head was close to a large bundle of rotting sugar-cane tops, while piled about us were reams of paper, containing between their leaves botanical specimens, many of them imperfectly dried. Indeed, every available space in the ship was blocked up with stores, baggage, and natural history specimens, both animal and vegetable, which not only prevented a free current of air, but poisoned what we had.

Nevertheless, by the mercy of God, we arrived safely at the Kongone mouth of the Zambesi soon after midday on the 3 oth of April. 
For three hours we waited for the rise of the tide, and then attempted to get into the river. The huge unbroken rollers were setting in from the south. The crash and confusion when they burst upon the bar was deafening. Such a tumult of water is rarely seen. It looked dangerous; but a sense of danger gives to existence an intensity that is not by any means disagreeable. For a few moments all went well with us. I was looking forward to a night of rest undisturbed by the rolling and pitching of the ship, when the man who was taking the soundings called out, "A quarter two," and then after another throw of the lead, "A quarter less two," and in quick succession, "A half one," and "A quarter one." We were out of the channel, and in another minute might be aground. Huge rollers wcre rushing at us broadside on. The vehemence of the surf was tremendous. A hundred yards more and we might be out of danger. The risk of attempting it was great. Failure would have been destruction. A battered ship, and a dead body washed on shore from time to time, would have told the tale of our disaster. The risk was too great; and Dr. Livingstone gave the signal to put the ship right about. She answered to her helm beautifully, and skimmed like a duck over the angry waves, that a moment before were threatening to overwhelm her.

Next morning, May I, SS. Philip and James' Day, a happy day for a missionary Bishop to enter upon his field of labour, our attempt to get into the river was successful. The passage of the bar, though turbulent, was not terrible.

There can be no doubt that the bar of the Zambesi is a formidable obstacle to the making of that river a convenient highway for commercial intercourse with the interior of Africa. The east Luabo mouth is said to offer greater facilities for navigation, and was at one time used by Portuguese ships. Should the Kongone ever become blocked up-and that is thought by some not to be improbable-the increased rush of water might sweep away many of the obstructions at the Luabo ; but until that takes place the best port for the Zambesi is that of the Quilimane river. The entrance is comparatively easy at all seasons of the year for ships of moderate tonnage, 
and at Quilimane itself there is much more convenience for ships than could be found either at the Kongone or the east Luabo. The great objection to the Quilimane river is that it is not a branch of the Zambesi. At Quilimane vessels with cargo intended for the interior must be unladen; the cargo must be put into canoes and carried a few days' journey up the river, and then conveyed overland some distance to the Zambesi; for the Naquaqua river, the feeder of the Quilimane river, takes its rise amongst hills somewhere behind Mount Morumbala, and does not communicate with the Zambesi. 


\section{CHAPTER II.}

$\mathrm{A}^{\mathrm{S}}$ soon as Dr. Livingstone made the Zambesi famous, the Portuguese erected a custom-house at the Kongone, and kept a few soldiers there. We found that the military consisted of a corporal and three or four privates, who were dressed in blue cotton uniforms. The corporal was a European, the privates were natives. Dr. Livingstone found letters from the Governor of Quillimane, in one of which he stated that the Bishop and his party had been strongly recommended to his good offices by his Government, and he therefore offered us all the assistance in his power. But at this period Dr. Livingstone seemed determined that we should have nothing to do with the Portuguese, and we did not avail ourselves therefore of the Governor's offer.

Inhamissengo, the island formed by the Kongone and the west Luabo mouths of the Zambesi, consists more of sand than mud, though mud and mangrove swamps prevail for some miles up the river. The dwarf palm abounds in Inhamissengo, and the natives, who are mostly the slaves of the Portuguese settlers who live on the delta, extract the juice of this tree, which when unfermented is a pleasant drink, and when distilled yields a not unpleasant spirit, which is called nipa.

The Portuguese in these parts of Africa divide the natives into two classes, colono and slaves. The colono are the original owners of the land, and are nominally free men. The whole of the Portuguese possessions are divided into districts called pracos, which, with the exception of a few crown-lands, are assigned to individuals who hold them at a nominal rent for a certain number of lives. The colono have to pay tribute 
to the owners of the pracos on which they live, besides which they are compelled to give personal service without remuneration, not only to the possessor of the soil, but to the crown officials also, and to supply with food, free of charge, soldiers and others who are travelling in the service of the Government. Upon the whole their condition is a wretched one.

Slavery is now professedly abolished in these Portuguese colonies, but until 1878 it was in full force. The slaves were acquired by purchase or by violence from the tribes of the interior. As a rule, the Portuguese themselves did not attack villages and enslave the inhabitants, though now and then an enterprising man amongst them would make a slaving raid, but generally they employed native agents to purchase what they wanted. They were able to do this because throughout East Central Africa slavery is an institution which exists amongst the natives themselves. Amongst those tribes, however, with whom we became acquainted, slavery was far less degrading than amongst the Portuguese. It was difficult to distinguish between the bond and the free, for all lived together and followed the same occupations. The system was patriarchal in its character, and father and children were the common terms used to designate the men who owned and those that were owned. But this system, comparatively harmless though it seemed to be in its working when undisturbed by foreign influences, was nevertheless a great feeder of the slave-trade. For certain articles of European manufacture are known to the natives and eagerly desired by them; and for such things as beads, thick brass wire, unbleached calico, and, above all, guns and gunpowder, the chiefs and great men, as by their laws they had the right to do, frequently gave in exchange men, women, and children that were in bondage to them. When, however, the demand for slaves was great, and the chiefs would not sell their own people, the slave-dealers kindled and kept up war between neighbouring tribes, that they might buy for slaves the prisoners which each side made.

In $\mathrm{I} 86 \mathrm{I}$ the slave-trade was made illegal in the Portuguese possessions of Africa, but as slavery was still permitted, the slavetrade existed also. It was carried on in order to supply the 
colonists themselves with labourers and domestic servants, and for illicit export across the seas, or into the far interior where women and children could be exchanged for ivory.

To return to the Pioneer. As soon as we were anchored in the river, the crew commenced to clear the deck and rearrange the stores; and next morning the Bishop and others of our party set to work upon the after-cabin, because most of our property was stored there. By opening the portholes, which it was impossible to do at sea, we got rid of the offensive odours, and by a vigorous application of broom and brush, and a more judicious storage of stores, a like grievance became again impossible. The ship had a thorough cleansing, and great was the comfort therefrom.

There is no good wood for steaming purposes at the Kongone, so the Pioneer was taken round to the Luabo. Our course was along a narrow canal-like channel of the Zambesi, which was thickly bordered by mangrove trees. Monkeys were numerous amongst the mangroves, and scampered, and chattered, and barked at us as we went along. The only birds we saw were a few pelicans and hawks.

We halted for the night opposite the house of a Portuguese who was on the bank of the river, with his slaves, a sturdy set of men and women, round about him. He was a miserablelooking creature, weakened by climate and disease. Amongst the slaves were two or three men who looked sturdy enough to overthrow fifty such as he, and I could not help wondering at the mystery of their being held in bondage. He saluted us courteously, and invited us to his house. His first inquiry related to the Landeens, who are an offshoot of the Zulus, and who have made themselves masters of the coast country from Delagoa Bay to the Zambesi. He was dreading an invasion of these people, for they were continually harassing the Portuguese settlers, and made them pay tribute for some of their best estates on the south back of the river. If it were not for the Zambesi, which they do not care to cross, if they only had guns, the Landeens would have but little difficulty in driving the Portuguese from all their possessions ; for in most of their encounters with them the Portuguese have been beaten. 
The Luabo mouth of the Zambesi is more pleasing than that of the Kongone. Game of all kinds is abundant; and we had not been at anchor long before two of our party, who knew well how to use a gun in England, went after fresh meat. But the experiences of English sportsmen aid them but little in Africa; and Dr. Livingstone, anticipating the result of their efforts, called one of the Makololo to him and said, "Mobeta, take your gun, go ashore, and bring us back a buck; we have not had fresh meat for some days." Mobeta was delighted, and running down below, reappeared with his gun, a genuine "Brown Bess," and started on his venture. He returned before the others, and was the only one who brought back game. He shot a bush-buck.

While waiting at the Luabo I had my first attack of fever. I was not very well for two days, and felt that I might soon be worse. Then my ankles, my knees, my hips, my back, my eyes, and my head began to ache, and the pain increased until it was almost beyond quiet endurance. I was unable to stand, and yet found no relief from lying down. Dr. Livingstone's pills, the "Zambesi Rousers," as they were called, were administered, but the fever symptoms increased. Now I was burnt with heat, then I shivered with cold, then I became a little delirious, and had hard work to keep from talking nonsense. But on the third day I fell into a sound sleep of some hours' duration, and when I woke, I felt not much the worse for this my first attack of African fever. It was not a severe attack, but it was the severest I ever experienced.

On May 7 th we began the real ascent of the Zambesi, and Dr. Livingstone said that in less than three weeks we should be at Chibisa's village on the Shire, where we were to disembark for the highlands. We made a long run, and when we halted for the night, were fully sixty miles from the sea. Here the Zambesi was a magnificent stream to look at, being more than a mile broad. But for the greater part of the year it is a wilderness of sand islands, between which the water flows in small streams that are only deep enough for the ordinary canoes of the country. The valley hereabouts is a vast plain of giant grass, without a hill, and almost destitute of trees. 
During our day's progress we passed several native villages and some Portuguese residences, though none but natives came to look at us, and a wretched sort of people they seemed to be. We passed also numerous hippopotami, several crocodiles, and saw many kinds of birds, some of which are rarely seen in England save as stuffed curiosities.

Dr. Livingstone had been anxious to get to Mazaro before halting, but the sun went down before we could reach it. The last gleam of light, however, gladdened our eyes with a sight of the wood-covered hills about Shupanga, and with a glimpse of the summit of Mount Morumbala, which looked beautiful in the purple reflection that was shed by it.

As we approached Mazaro next morning the whole population of the place turned out to see us. We did not stop at the town, but dipped our bunting as we passed it, in compliment to the Portuguese flag flying there, and were saluted in turn. We halted, however, at the residence of the Senhor, who was the great man of the district, and who lived a short distance above Mazaro. -He was a miserable-looking old man, nearly blind, and very deaf. Terrible stories were told about this man, as indeed about almost all the Portuguese who had become conspicuous in this part of the world. They related for the most part to their doings as slave-traders or slave-holders; but as a better state of things now exists, it is scarcely worth while to reproduce them. We stayed but a short time here, and then made for Shupanga, which is on the other, the south side of the river.

The house at Shupanga is large, and so situated as to command a fine view of Mount Morumbala and the country intervening. It is surrounded by plantations of orange, lemon, mango, and cocoanut trees. But the house was uninhabited and falling into decay, for the Landeens had driven away the residents by their threats and exactions.

Dr. Livingstone kindly suggested that we should take from here cuttings of orange and other fruit trees, and the roots of pine-apples, as these things were little known in that part of the country to which we were going. His good-nature cost him dearly, for in consequence of taking the Pioneer as near as 
possible to the plantation where these things might be had best, the ship swung on to a sandbank, and there remained for three days. After we were out of this difficulty the engines refused to work, and another delay occurred while the engineer repaired them.

While waiting here we were visited by several of the muchdreaded Landeens. They were fine stalwart fellows, but looked like savages. They wore a kind of kilt made of monkey skins, and their loins were covered with strips of monkey and buck skin alternately arrayed. Their necklaces were made of the horns of a diminutive antelope, which were strung through the roots, and some of them wore bracelets and rings made of thick iron wire. Their snuff-boxes (and all the natives indulge in snuff) were made of a section of bamboo, and were elaborately carved. One man carried his snuff-box in a hole made in the lobe of one of his ears. Those who visited us were, with many others, living upon the villagers near to Shupanga. They comported themselves even when with us as lords and masters, and I have no doubt that the natives whom they subjugate have a hard time of it. They were well pleased with their visit to us, for Dr. Livingstone conversed freely with them, and dismissed them with suitable presents.

As yet no attempt has been made to Christianise these people, who would as Christians be as powerful for good as they are now powerful for evil. If all goes well, however, an effort will be made by some of our American brethren to bring them to Christ, for a mission to their country has been decided upon, and will be sent out as soon as arrangements can be made.

When we recommenced our voyage, our progress into the Shire was pleasant and urobstructed. The character of the country on the Zambesi improved the higher we went up it. Well wooded and picturesque hills and lofty mountain-land gratified the sight. It was, however, with feelings of sadness that we looked from the country to its inhabitants, the degraded men and women, gazing at us from the banks of the river. Beholding the fair landscape only, you felt inclined to exclaim, "All things are very good;" but beholding the dark crouching forms of the men and the women, we seemed to be in the 
visible presence of evil-of evil so long inherited and so deep seated, that it has all but deprived its victims of the power to appreciate that which is good.

We ascended the Shire a few miles and then halted. Our halt extended to several days, for Dr. Kirk went on business to Sena, and we awaited his return at a place called Shamo.

Dr. Kirk returned on the 17 th May, and we waited two days longer for the arrival of certain goods belonging to Dr. Livingstone, and for some slaves which he had borrowed of a Portuguese at Sena to help him up the river and on his land journeys.

Few things are so painful to behold as the debasement of your own kind, from whatever cause it arises, and I felt this strongly when these slaves came on board. The elder of them looked as though their lives had been encircled with evil, until its very essence had moulded itself into their natures. Degradation of body, soul, and spirit was stamped upon them. The younger of them presented a far more hopeful appearance, and under the better influences which prevailed on board the Pioneer they bore themselves almost as free men. The thought that they would be returned to the old brutalising state of things as soon as their services were no longer needed by the expedition was hard to bear.

We left Shamo on May 2 oth. There was nothing to obstruct our progress on this day, for though the river was narrow, it was deep, and we anchored for the night at the foot of Mount Morumbala.

As the sun set the clearness of the atmosphere brought into view the outlines of Morumbala and the adjacent hills witn great distinctness, whilst the colour on and about them was beautiful and greatly varied. We sat up late that night talking of the work before us and singing hymns of praise to the Giver of all good.

When morning broke a cloud was on the mountain-top, a not uncommon occurrence, as the condensation of vapour about its summit at all seasons is great. Being an isolated mountain, and of all the hills of that part of the land that which is nearest to the sea, it attracts to itself all the storms that there wander about, 
and is exposed to the war of the elements more frequently than any other part of the country, though on the night of our arrival it seemed to be the tabernacle of peace.

The view from Morumbala is extensive but not cheerful. The Shire valley thereabouts is filled with swamps from which poisonous vapours arise; so that if you ascend the river at the worst season of the year, as we did-that is, when the swamps are drying up-and if you are detained any great length of time in these pestiferous localities, as we were, you will probably suffer severely from fever. But if you go up the Shire between July and the end of October, during which time the swamps are generally dried up, and the flow of malaria to a great extent ceases, you may escape fever altogether; and if you do not, it will probably be of so mild a form that you will not suffer from it much more than from an ordinary influenza cold in England. And if you can get to the highland regions without fever in your veins, you may live there as free from physical inconvenience as Europeans do on the highlands of India.

We steamed for thirteen hours on the $22 \mathrm{~d}$, and did more than sixty miles. The valley widened some distance above Morumbala, and the country beyond was mountainous. Mount Clarendon (so called by Livingstone) rose high in the air, whilst others less lofty arrested the eye by their oftentimes grotesque formation. Towards evening we caught a glimpse of the Milanji mountains; it was but a glimpse, yet it enabled us to form some idea of the prominent features of the region to which we were going. Viewed from where we were, they looked almost as grand as the giants of the Alps when seen at a distance.

The population of that part of the valley through which we had passed was scant. That it could have been thickly peopled seemed to me impossible. Under the hills that shut out the Zambesi from the valley of the Shire, and also along the base of the hills which trended towards the Milanji, and amid the clumps of trees which here and there were seen in the valley itself, villages probably existed, but the inhabitants were not many, and such of them as we saw looked poverty-stricken and miserable. 
Towards the close of our day's journey the character of the valley improved, and the population seemed to be somewhat larger. We halted opposite to a village, the largest we had yet seen, called Kulubvi, where Dr. Livingstone hoped to make considerable purchases of corn and rice. When Dr. Livingstone first went up the Shire, the people of this place, as well as of most others, were distrustful of him, and came down to the banks armed and ready for war. This was very natural, for I doubt if they ever before had reason to regard with favour any man with a skin lighter than their own; but now, no sooner was the ship anchored than men, women, and children flocked to the river-side with every demonstration of pleasure, and a number of men whose delight made them boisterous came off to the ship.

Long before daylight we were awakened by the clamour of the people on shore, and when the fog cleared away (for morning fogs are very common on the Shire at certain seasons of the year), we saw that they had brought rice and other things for sale.

We missionaries were naturally anxious to make the acquaintance of these people, for they belonged to the Manganja, the tribe with whom we were going to live, so we went ashore to purchase what we could for the mission.

Bartering with them was merry work; for though for a certain length of cloth (unbleached calico) you could buy a certain quantity of rice, the quantity of rice brought for sale was often uncertain-less, that is, than that which commanded the standard payment, viz., two or four yards of cloth, or the equivalent in beads or brass wire. You had therefore to regulate your payments accordingly, and this led to a great deal of chaffering. They stipulated for a little more than you offered to give, and pretended to be highly indignant at your not complying with their request. The lookers-on roared with laughter or shouted encouragement to their friends at the various turns in these transactions. When the women were associated with the bargaining, if the affair did not take exactly the form which they wished for,-if they found they stood but little chance of getting what they wanted, they raised their arms as well as 
their voices, and strutted about in apparent ire, giving vent in the meantime to their feelings in language that was without doubt highly vituperative. But the end of all was utmost good-humour; indeed, while they scolded and expostulated they seemed barely able to keep from laughing, for they received with evident pleasure the very thing they had but a few moments before refused with so great a show of indignation.

I was much struck with the regard which the men had for the women, whose position seemed to be no way inferior to that of the men; and the men, not the women, carried the heavy burdens of rice that were brought for sale. Indeed, it was at times amusing to see the deference which the men sometimes paid the women by going to them and asking their opinion before concluding a bargain. There seemed to be but little of the savage in these people. Heathen and barbarous they were, but savage I did not think them. I could not regard them as "the vilest and most degraded of men, whose sins have blackened and defiled the earth;" for I felt in a purer atmosphere when amongst them than when standing by the side of Senhor — on the Zambesi. That some amongst them deserved what was thus said of the whole, I did not doubt ; for now and then there came into view a face so repulsive in its expression and formation, that you felt that the man to whom it belonged was one of a class common to all communities, who will unhesitatingly sacrifice your life, if they can, when they find it stands between them and the attainment of their desires. But as a set-off to this, there were others who, under more favourable circumstances, would have few superiors in character and intelligence. The majority, however, seemed to be what might be termed commonplace sort of people. Indeed, taken altogether, they were naturally very much like people anywhere else.

The women wore the hideous lip-ring, of which I have already spoken, and most had shaved off the hair from their heads. The men were not disfigured, save by a triangular notch in their front teeth, and they wore their hair dressed in fashions that were sometimes grotesque, but often becoming: 
Here the hair seemed to be the glory of the man but the shame of the woman.

Up to May $25^{\text {th }}$ we met with no obstructions to our voyage up the Shire. On the $25^{\text {th }}$ we did not come to any lengthened stoppage, but our progress was frequently checked, and the distance done during the day was trifing. We halted for the night not far from the village of Tingani, one of the two great chiefs of the Manganja, who are called Rundos; but as he was not lord paramount of that part of the country in which we hoped to settle, we did not attempt to make his acquaintance. The difficulties connected with the navigation of the Shire commence some distance below Tingani's village. A multitude of islets intercept and turn aside the stream. The passage in many places is so narrow and tortuous and the current so strong, that progress in such a vessel as the Pioneer was not possible without much patience, labour, and loss of time. Our experience in the Rovuma was severe, but it was nothing in comparison with that which we had in the Shire from the commencement of the Elephant Marsh, just above Tingani's, till within a short distance of Chibisa's village. Indeed, for some days it seemed that it would be quite impossible to force the Pioneer up to Chibisa's ; and it was not until the afternoon of July 8th that we arrived there.

It would be wearisome to give at length our day by day experiences; a few indications of them will be quite sufficient. For June $\mathrm{x}$ th I find written in my journal :- "Afloat once more! But if the experience of the last fifteen days may be looked upon as a criterion for the future, it will not be many hours before we shall be aground again. It is about three weeks since we entered the Elephant Marsh, and we have been twenty-four days in getting over half as many miles."

The ship was damaged somewhat by the rough usage to which she was subjected, and we were damaged also by the pestiferous exhalations of the marsh and the hardships of the way. None of the mission party escaped fever; some suffered severely.

On the $r 8$ th of June we lay at anchor all day. On the $r 9^{\text {th }}$ we got several miles up the river, and seemed to be getting 
out of difficulty, for the valley was narrowing, and the hills which flanked it had a cheerful appearance. At night I could not help congratulating Dr. Livingstone on the fact that from sunrise to sunset we had actually come six or seven miles. But we had not gone half-a-mile next morning before we came to a regular barrier of sand, and three and a half feet of water was the greatest depth we could find. This obstruction continued for more than a hundred yards. The current was not strong, and the bottom therefore was hard. Selecting the best spot he could find, the Doctor ran the ship well on to the bank, then anchors were taken out ahead, and she was drawn up to them by the use of the capstan. It was very slow and very hard work. One day we did not move a foot. Then we emptied the boilers and succeeded in getting over a hundred feet. Then we found it necessary to unlade the ship of everything that was weighty; and so after eight days of constant labour the ship slipped into deep water.

Of course there were compensations even to this wearying sort of life. The weather was pleasant, not very hot, though the temperature for some days had been steadily increasing. We were by this time fairly out of the rainy season, though now and then we caught a shower, but generally day succeeded day with an unclouded brightness. For several days we had before us an immense grove of palm trees, which lay right between us and the west. Some of these trees were of great height, and their graceful stems and beautiful foliage stood out in bold relief against the glowing evening sky. The effect of the sunset was most soothing. Day by day we had to labour hard and endure much anxiety, and to suffer much inconvenience from the pain and lassitude begotten of fever, yet it was with feelings of thankfulness and peace that we beheld the evening star shining like an atom of burnished silver through the fiery-looking atmosphere in which it appeared.

Besides this, it was almost impossible to feel dull where animal life was so abundant. In the Elephant Marsh we one day saw more than five hundred elephants. Elsewhere we frequently caught sight of zebra, deer, and buffalo. All along the course of the river there are many kinds of birds, and some- 
times they appeared in great numbers. In the river crocodiles were numerous; I one day counted seventy-nine basking at one time on a small sand island; and the hippopotami were more common than dogs in our streets.

The hippopotami, indeed, were a constant source of amusement to us. One of them, however, once provoked an amusement that was somewhat out of place. It was Sunday, and all hands were mustered for divine service. I had heard this creature-for I slept on the deck of the ship-feeding quite close to us during the night, and in the morning he dodged about us as though he knew that he was safe from the gun on that day. When service commenced, finding no one moving about the ship, he grew bolder, and came quite close to us, and repeatedly gave us the full benefit of his huge lungs. His utterances were distracting, for a tremendous " $\mathrm{Ha}$ ! ha!" at the end of a solemn supplication was no aid to devotion, and a running accompaniment of the same jovial ejaculations was quite sufficient to impair the effect of the Bishop's sermon. The sailors were ready to explode with suppressed laughter, and so was $I$. When the service was over all ran to look at the brute, who caught sight of our eager faces, and evidently expecting mischief, dived down and reappeared some distance below. Then he gave another look, as though measuring the distance between him and the ship, and not being quite satisfied that it was safe, dived down again, and rose still farther below, where he shouted defiance at us all day long.

The flesh of the hippopotami when young is in tenderness and flavour something like veal, but when old it is as tough as leather, and unlike any creature I have tasted. One day the carcase of a hippopotamus that had been killed by a trap floated by the ship. The Makololo went after it. Having secured it, they cut it up and distributed it. A hind quarter, a delicate joint which had to be hoisted on board with rope and pulley, was Dr. Livingstone's portion. I looked well at that joint; it had the appearance of beef, and I expected considerable satisfaction from the experimentum gustus next morning. But my anticipation of a pleasant meal of fresh 
meat received a shock when I heard the Doctor tell the steward to stew the steaks for breakfast for at least four hours. Had they been stewed for forty hours they would have remained tough. We did what we could with them, but to save our teeth we endangered our digestion.

Through our long delays in the river we made a more extensive acquaintance with the natives, and in a village not far from the place where we were aground for so many days we saw several groups of men crouching round their respective fires, smoking and being smoked, and enjoying the latter operation, it would seem, quite as much as the former; for they thrust their heads into the pungent fumes of the wood, and twisted themselves about as though it gave them a great physical gratification. One group consisted of travellers, who, from their tattoo-for each tribe has its distinct tattoo-the Doctor informed us were Ajawa, who he declared were above all other tribes engaged in the slave-trade and the disturbers of the peace of the country.

About this time we had much conversation with regard to the course we missionaries should adopt with respect to firearms. Two questions arose:-First, Should we take guns with us to the highlands? Secondly, If so, for what purpose should we take them? The Bishop was against taking guns for any purpose whatever, but Dr. Livingstone and others belonging to the expedition said, "By all means take them, and, if necessary, use them. But if you take them, depend upon it there will be no need to use them, for they are the greatest peacemakers in this part of the world, if you have peaceful intentions yourself. The Ajawa and all other tribes, if they know you to be well armed, will assist you, and they will never dream of attacking you unless you are defenceless." And ultimately it was agreed that we should take our guns with us.

When we were not far from the village of Mankokwe, the Rundo or supreme chief of that section of the Manganja amongst whom we were going to live, Dr. Livingstone, Dr. Kirk, the Bishop, and others, went to visit this great man. They arrived at a very sorrowful time. Some women and a child had just before been drowned when crossing the river, 
and this accident was regarded as a public calamity. Mankokwe, however, was inclined to be gracious.

A conference with such a man is a very ceremonious affair. It is not etiquette on such occasions to address yourself to the chief; he has a speaker, and you must have a speaker, and what you have to say you must say to your speaker, who tells what you have said to the chief's speaker, who thereupon informs his lord of what he knows already, seeing he has heard it twice before. Charlie, one of the Makololo, acted as Dr. Livingstone's spokesman, and an old man named Chimbeli officiated for the Rundo.

The Doctor began by introducing the Bishop and saying something of the object of his coming into the country. Mankokwe replied that he was glad to see the Bishop, but upon his purposes in coming he said nothing. Much more was said, and Mankokwe seemed to be so amiable that the Doctor proposed to leave the ship where she was while the necessary land journey to the highlands was undertaken; and to this Mankokwe did not seem to have any objection.

Next morning Chimbeli, accompanied by three young men, came down to the ship, bringing with them a goat as a present from Mankokwe, in return for the presents he had received the day before from the Doctor and the Bishop. The young men seemed fearless and behaved frankly, but poor old Chimbeli was greatly alarmed when the ship was put in motion; it was quite distressing to witness his agitation. After a time he recovered, but upon being shown over the ship, he lifted up his hands and exclaimed, "I have no more breath. My heart is taken away. It is wonderful!"

Around Mankokwe's there was a great luxuriance of vegetation. There were many banana-trees laden with fruit or putting forth their huge egg-shaped rich purple blossoms ; the fig-trees, highest of all trees hereabouts, spread their wide branches over the village; the wild vine threw its graceful tendrils from tree to tree, and huge clusters of bright yellow grapes, that were unfortunately not edible, gratified the sight. Nothing could be seen of the village from the river, the huts being hidden by the thick foliage of the trees. Here and there an arcade was made 
through the embowering branches, down which the people came to the river; and notwithstanding the village was still a house of mourning, a considerable number of the inhabitants came to the bank to meet us when we landed.

We took with us a pair of turkeys and a ewe merino sheep (the ram died in coming up the river), intending to leave them in Mankokwe's care, the creatures having suffered much by their long confinement on board ship. Chimbeli, who had quite recovered from his fright, preceded us into the village, having over his shoulder a bright-coloured scarf which Dr. Livingstone had given him; and the air of importance which he now assumed was very amusing.

The village was larger than any I had seen, and it was thronged with life. The number of dogs-a mongrel terrier breed-was a nuisance; and the crowing and the cackling of poultry, the vociferations of goats, and the bleating of sheepblack, short-haired, large-tailed creatures-showed that where the Rundo lived plenty abounded. Our white sheep excited much attention from the crowd of well-fed, good-looking natives that accompanied us, for a sheep with so small a tail and covered with white wool had never before been seen by them.

We soon came upon signs of the calamity of the day before, - the charred remains of a freshly burnt hut, and seated on the ground several women on whose heads was the emblem of woe, and who, while rocking themselves backwards and forwards, gave vent to their grief in an ear-piercing wail. They were weeping over the desolated hearth of one of those who had been drowned. Their sorrow seemed to be sincere, for their countenances expressed suffering. Strange as must have been the appearance of so many white men, the mourners noticed us not; they seemed to be quite absorbed by their grief. The village rang with their wail of woe. Theirs was not that

"Unimpassioned grief,

Which finds no natural outlet, no relief

In word, or sigh, or tear ;"

but a grief that found an abundant expression in one of the most painful utterances that ever conveyed tidings of sorrow 
to man. We halted under a large fig-tree growing in an open space in the centre of the village, from whence we were soon summoned to the presence of the Rundo. Mankokwe was a tall man with a well-formed head. Unlike most of his countrymen, he had both beard and moustache. There was an air of superiority about him, yet he looked like one that might do both mean and weak things. He was seated on the projecting roots of a fig-tree which grew close to his hut, and he had on a wrapper of blue calico. He wore brass bracelets, brass anklets, and he had a brass snuff-box in his hand. A little to the right of him and slightly behind sat ten shaggy-browed old men, who were the counsellors of state. Dr. Livingstone sat down by the side of the chief, Dr. Kirk sat by the side of him, two mats were spread for the Bishop and the rest of the party, and then Chimbeli with a profound reverence to the Rundo sat himself down just in front of us. A number of men and boys ranged themselves round about us, and looked on with eager curiosity.

Before the conference commenced, an intelligent-looking woman with a large tumour at the back of her neck came up, and falling on her knees bowed her head to the ground before the Rundo, and begged in a humble voice permission to be present. She was his sister, and her request was granted by a simple inclination of the head. The favour accorded to her was taken advantage of by other women, all of whom wore the abominable lip-ring, and were also elaborately tatooed.

Dr. Livingstone commenced proceedings by saying that he wished to leave the sheep and turkeys in the village. The animals were brought forward. Mankokwe looked interested, but asked no questions concerning them, yet he examined with attention a piece of wool which had been plucked from the sheep's side. Then the sister plucked a bit and twisted it into thread; then all the women plucked, until there seemed some danger of the poor creature being shorn in a way that she had not been used to. So the sheep and turkeys, consent being given, were let loose and allowed to wander at will.

After this, we, who then visited him for the first time, were introduced to the Rundo, and he was informed that $I$ was to 
be left with him while the Bishop and the rest of our party went up to the hills. To this the great man said nothing; he honoured me, however, with a look and a smile, and gaped immediately afterwards. But when Dr. Livingstone again spoke about his ship, it appeared that the old wise-heads then present had been talking the matter over, and had come to the conclusion that the ship had better move on. There was, the chief said, plenty of water between his place and Chibisa's; it would be better, therefore, to go there. Of course we might wait where we liked, yet he should prefer our not waiting at his village. He was quite willing that we should go to the hills, and that some of his people should accompany us; yet, all things considered, he would rather not let any of his men act as porters for us-that was, just then. He professed to be willing to grant us everything that we asked for, and yet he refused us everything that we needed.

Here the sister again interposed, and after apologising for not having any food to place before us, excused herself on the ground of the great calamity that had befallen them, and then begged for permission to retire and mourn. 'This being granted, she left, and all the women followed her.

The mention of food tempted Mankokwe away for a short time. While he was absent Chimbeli found his supply of snuff exhausted, and looked about for a pinch. Procter, who carried a snuff-box, extended it to him, and the look of Chimbeli when he had fairly taken a pinch of rappee was suggestive of deepest satisfaction. One pinch gone, he took another, and another, and another, and his long-drawn gasps of satisfaction told how fully he appreciated its excellence. Then the noses and the fingers of all around became excited, and all the old fellows had pinches; and so great was their pleasure thereat, that when Mankokwe returned, he to his evident surprise found them all in a state of hilarity; but a pinch from Procter's box made him almost as forgetful of his dignity as they had been of theirs.

Food, consisting of curried fowl, nsima (thick porridge made of Indian-corn meal), and pombi (the native beer), was given to us; but before we had finished our repast news came that the 
body of one of the drowned women had been recovered, and was even then being brought to the village. Upon this all the people, with the exception of the chief and his counsellors, hurried away. We also made haste to depart. As we left, we found the people everywhere in the full excitement of grief. The women were crying, and wailing, and beating their breasts ; and their lamentations increased to an exceeding bitter cry when the corpse, rolled up in a sleeping-mat, was carried into the village. The character of their grief was suggestive of something more than sorrow for those who had been taken from them; it seemed to partake of fear of some imminent danger to themselves. "An enemy hath done this" was the evident thought of all, and each seemed to think that he or she might be the next victim. I afterwards discovered that almost all kinds of sickness, accident, and death are ascribed by the natives to the effects of witchcraft, and this doubtless accounted for the fear that was upon Mankokwe's people.

Dr. Livingstone and the Bishop again visited Mankokwe, taking with them a variety of presents, such as shawls, lookingglasses, knives, and beads, and when the Doctor said he doubted if we should be able to get the ship up as far as Chibisa's, Mankokwe had no doubt about it, but added, "Stay where you like above me. You came as friends, you act as friends; you are not to be driven away like dogs. Stay where you think proper, only I should like you to get up above me as far as you can." He afterwards said, that though Rundo, he had very little power over the other chiefs, and if they saw the English with him, they might not like it, but would probably be angry with him for allowing strangers to settle in the land.

The dislike which African chiefs have of introducing strangers into the country is not surprising, for those who introduce them are held to be responsible for any evil that may happen, or may be supposed to happen, through their presence, and strangers are frequently thought to bring a lot of evils in their train.

The presents put a stop to all further talk on grave subjects, but in the end they produced an effect quite contrary to that intended. They were too valuable, and the old wise-heads 
came to the conclusion that we intended them as payment for the land we might live on; so it was resolved to return everything that had been received from us, and this was done with an intimation from the chief that his land was not to be bought.

Dr. Livingstone resolved to trouble himself no more with this man, but to act without his concurrence. So the Pioneer was pushed ahead, and arrived at Chibisa's village on the afternoon of July 8th, having been sixty-nine days in coming up from the Kongone. 


\section{CHAPTER III.}

CHIBISA'S village was built on the south side of the river, on a bank of stratified sand about sixty feet high, the view from which was really beautiful. A group of thickly wooded islands, the largest of which was called Dakanamoio, made the river look like the ornamental water of a park, the valley was free from swamps and richly adorned with trees, and mountain beyond mountain rose up to the view as far as the sight could penetrate. But Dr. Livingstone promised even better things when he got us into the highlands.

We found in the village a party of travellers from the neighbourhood of Mount Zomba, who were on their way to Chibisa, who was living at Doa, a place on the Zambesi lying between Sena and Tete. They were Manganja, and from them we learnt that the Ajawa had invaded their country, were destroying their villages, and killing and enslaving their people. They were going to Chibisa to solicit his aid against their enemies, for he alone, they thought, was able to overcome them, as he alone, it was said, had the true medicine to make guns harmless.

Chibisa was evidently the great man of this part of Africa; Mankokwe might be the Rundo, but Chibisa was the hero. Of his origin little was certainly known. He said he was a chief and the son of a chief, but the Portuguese declared that he was a slave and the son of a slave at Tete. It is probable that he was an adventurer, who had made himself powerful by his cunning and daring, and had obtained a reputation for successful warlike achievement greater than that of any of the Manganja chiefs. 
Dr. Livingstone was confident that the Ajawa were aided by the Portuguese, who it is certain were profiting by the strife, for, as I afterwards heard from one of themselves, they were at this time taking at least two hundred people, mostly women and children, out of the hill country every week. They were getting slaves there in order to dispose of them to the Banyai, who live far in the interior, in exchange for ivory. It seems that the Banyai had been defeated in war by the Matabele, had lost most of their own women and children, and were replacing them in the way described.

On the morning of the 9 th July we made a formal visit to the head man of the village. It was not so ceremonious an affair as that at Mankokwe's, but it was more satisfactory. The people wished us to stay with them; but as we proposed to build houses, the head man thought that Chibisa's permission should be first obtained, and he promised that he himself would at once proceed to Doa in order to get it.

After the conference the Bishop and I went in search of a site for a house, and we found one at about a quarter of a mile from the village, which commanded an excellent view of the river and valley and mountains beyond.

Dr. Livingstone decided upon commencing the journey to the highlands on the morning of Monday, July $\mathrm{r}_{5}$ th. The Bishop gave to me Chibisa's village as my parish, and it was expected that I should be some months in the valley.

Our stores had been removed on to Dakanamoio, and when I took account of them, I found that our stock had been reduced to less than the half of what it was when we left Johanna, and that we were in preserved meats and such-like things still greatly in debt to the expedition. But food seemed to be plentiful in the country, and as we had barter goods in abundance, we were not alarmed.

We made all the preparations we could for the journey, but were not successful at first in persuading the natives to enter our service as porters. On the Sunday evening, however, several men offered to go with the Bishop, and Dr. Livingstone placed six of his men at the disposal of the mission, but many more were needed. 
By daybreak on the $\mathbf{5} 5$ th all were ready for the journey. It had been raining during the night, and it was a dismal-looking morning; nevertheless there was no one that did not seem cheerful. Dear Scudamore made us all merry with the quaintness of his personal arrangements. He was always quaint, always happy, always one of the most lovable, gentle, and brave-spirited of Christian men.

I made a last survey of the forty days' supplies that I had put up for the mission party, and could not help feeling anxious when I fully realised how scanty such a provision was. The Chibisians who had engaged to assist in carrying burdens did not appear at the appointed time, so we sent William (one of the coloured men we brought from the Cape) to hunt them up, and to our great satisfaction he came back with them and some others, so that the mission party had twenty-one porters at its command. I immediately packed up the camp-beds of my brethren, and a little more clothing and a few more comforts for each person, and another burden of barter goods was added to their stock.

Then came the allotment of burdens to the bearers, and this was by no means an easy matter to settle. Some of the burdens were larger than others, some heavier ; and the contention amongst the Chibisians and between them and myself, before each man was fitted with his particular load, was a trial of patience. With the expedition party there was no such contention, the Makololo and the Sena men did just as they were bidden, and were out of the ship and on the march before we were ready to follow them. But when all seemed ready, and we were about to start, then our fellows discovered that they had not got their bows and arrows. This was a vexatious discovery, for they would not go without them. I laughed at them, I coaxed them, I did everything but thrash them, in order to get them off, but in vain; they would not go without their bows and arrows, for none but slaves went abroad unarmed, and so they went back to the village for them, I and William going with them to ensure their return. When they were in the village they were in no hurry to get out of it; more words had to be said to their wives, a little more smoking and 
snuff-taking had to be done with their friends, and they even sat down and looked as though they did not intend to move for a week. At length I persuaded one man to put down his pipe and come with me, hoping that the rest would follow his lead. This they did, and with them came nine others also, for whom burdens were provided.

The Bishop and the men previously engaged had gone on ahead, so I and Waller followed with those who volunteered last, it having been arranged that I should go some distance on the day's journey and return. The country we passed through was as wild as the most enthusiastic lover of uncultivated nature could desire. After walking nearly four hours we overtook the Bishop and Dr. Meller, surgeon and botanist of the expedition, who being left in charge of the ship, was to return with me. They were waiting for us at the entrance of a rugged mountain-pass which led up to the higher land.

The Bishop carried his pastoral staff in one hand and a gun in the other. The staff was given to him by some of the clergy at Cape Town. He thought that it had better be connected with his first real missionary effort in the land where he was to act as Bishop, and that no person was so fitted by office to carry it as himself. After we had started on our different ways, we turned to have a last look at the Bishop, and saw him marching on with huge strides after the bearers, the gun depressed, but the pastoral staff elevated and well in view.

It was arranged that I should sleep on board the Pioneer until my house was erected. Gamble, the carpenter, who had suffered much from fever in coming up the river, and was then unable to undertake the land journey, and Job, another of the men from the Cape, who acted as my interpreter, slept in tents on the island.

It was my intention to build two houses, one on the island for the stores, the other on the bank for a residence. The spot I chose for a storehouse required a great deal of clearing, so I set to work upon it, Gamble and Job aiding me. It struck me, however, that I might get some of the natives who were looking on to help us; so Job put me in communication with one of them, a man named Chechoma. This man was held 
in some reputation among the Chibisians. He was a thin little fellow with a big head, and an inveterate talker. I explained to him what I wanted. The thing was novel; it had never before been heard of in the Chibisian community. But Chechoma's mind grasped it; he saw the advantage of work followed by pay, and he harangued his friends upon the advantage they would derive from accepting my proposal. Four men, influenced by his eloquence, agreed for a certain length of calico to fetch enough of sand from a hillock close by to raise the site of the storehouse to the required altitude. They worked merrily enough for about an hour, and then it occurred to them that such an occupation was "woman's work," and they declared that they would do no more of it. I laughed at them, and told them that in England men always did that kind of work, upon which they began again; but had I not worked with them, they certainly would have gone off. When I paid them, however, they were delighted, and seemed to think that working for the English was not such a bad thing after all; and from that time I could always command the assistance of as many men as I needed to do whatever I wanted done.

Dr. Livingstone's belief that the Portuguese were directly implicated in the war between the Ajawa and the Manganja received an ample confirmation on the $\mathrm{I} 7 \mathrm{th}$; for on the afternoon of that day nearly a hundred men, most of them armed with guns, passed over the river not far from where the ship was moored. All these men were Africans except the commander, and he was a Portuguese. We learnt from the Chibisians, whose canoes were used for this occasion, that these people had come from Tete, and were going up to fight the hill Manganja.

As we watched them, some of the men who had accompanied the Bishop returned. They were in a state of great excitement, and informed us that they went up as far as Mbame's village, about twenty miles off; that when there a party of slave-dealers from Tete had come into the village with a number of slaves; that the English, after taking their guns from them, had driven them away and had set the slaves free. Presently several more men came in, bringing with them 
a gun, a number of hoes, earthenware pots, brass bracelets, \&c., which had been taken from the slave-dealers. One of these men brought a letter from Dr. Livingstone to the officer in charge of the ship, which, after stating that he had the day before released eighty-four slaves and dispersed the slavers, instructed him to man the boats and go in pursuit of another party of slavers that had escaped him and would be down by the river with their slaves almost immediately, to disperse the slavers, retain the slaves, and to enlist the Chibisians on our side by promising them all the booty they could take.

Dr. Livingstone had evidently made a declaration of war against the slave-dealers, and the campaign promised to be a serious one. The Chibisians were not inclined to enter upon active hostilities with the Portuguese and their allies, but they promised to keep a good look-out, and to let us know if any slavers attempted to cross the river. Upon that promise it was thought expedient to rest for the time being.

The next day, July I8th, was eventless until about 5 P.M., when Dr. Kirk arrived. He had left the whole party and the released slaves that morning at Soche's, about thirty miles away, and had with four men been unsuccessfully in pursuit of a slaving party all day. We told him of the Portuguese and his men who had gone up to the hills the day before, and he gave me a letter from the Bishop, which said:- "Yesterday six or eight men passed through the village we were in with eighty-four slaves. They ran away, and all the slaves were freed. I was bathing at the time, and came up only in time to find them all sitting clothed, and cooking as composedly as if nothing had happened. To-day eight more were rescued. Kirk will tell you what he comes for. I am clear that in such cases it is right to use force, and even fire, if necessary, to rescue captives. I should do so myself if necessary, but I think it more becoming our office to see guns in the hands of others. Do as you think best. If you like, volunteer to Kirk to go in a boat with a gun; you have my approval of your doing so. I would say, if you are not required, 
be glad that you are not called upon. Receive any captives you can get; give them bits of cloth for decency; feed them if you can buy food for them. It is very likely that you may all be called up, that we may concentrate our force, sooner than we expected, and that the shed may not be required; but go on as you are doing till you hear again. There seems to have been great barbarity in the march down. All well. Procter little upset. Marching before breakfast is severe work. Scudamore says, 'Tell him I'm much obliged to him for packing up my bed. I've got it all right. I've only lost my note-book as yet.' - 'Any more?' - 'No, no more.' Addendum : 'I hope he won't beat his ploughshare into a spear altogether, or whatever it ought to be." "

'The Bishop in his letter says he found the released slaves "clothed and cooking;" when in the custody of the slavers they were literally naked, women as well as men and children, and from the spoil taken from their oppressors Dr. Livingstone gave each of them a length of cloth. All were very hungry, some were emaciated from want of sufficient food, but when food was given to them they seemed quite bewildered at the change in their condition. One little boy came up to the Doctor and said, "Where do you come from? The Chakundas (slave-dealers) starved us, but you say, 'Cook food and eat!' Where do you come from?"

The "barbarity" to which the Bishop alludes had indeed been great, and where the slave-trade is, men are most cruel. Some have thought that Livingstone and others have somewhat exaggerated the horrors of the slave-trade as carried on in Africa itself. I do not think you can do that. During my comparatively short sojourn in the land I became acquainted with so many deeds of cruelty connected with the slave-trade that I could fill a volume with the details of them. The particular instance of barbarity to which the Bishop no doubt here alludes was this :-Amongst the women that were released at Mbame's was one who was not, like the rest, made joyful by the regaining of her freedom. She was in a state of sorrow that seemed to overwhelm her. Upon making inquiries as to the cause of this, the Bishop learnt that only the day 
before, she, though a weakly woman, and the mother of a babe but a month old, which she was carrying at her back, had been given by the slavers a heavy burden of iron hoes to carry. She could scarcely stagger along with only the burden of her babe, and she could not carry the hoes and her babe also. To the slavers the babe was worth no more than a yard of calico, the hoes were of much greater value; so they took the babe from the mother, dashed its head against the rocks, and threw the little body aside as though it had been that of a dog. The men who did this, and other things like this, were from Tete: they were black men, it is true, but they were in the service of white men, Portuguese living at Tete.

After they had satisfied their hunger, Dr. Livingstone told the released slaves that they were as free as himself, and he advised those who had homes and friends to return to them. It was then found that their houses had been destroyed, their friends killed or dispersed - that they were, in fact, utterly destitute. Upon which, after consulting with the Bishop, the Doctor said, "My brothers here have left their own land to come and live with you, in order to make you a happier and a better people than you are, and to teach you about God. If you like to go with them, go; build where they build; they will protect you and feed you until you can feed yourselves."

They joyfully accepted this offer. Strange to say, we did not find that they had in their language a phrase equivalent to "Thank you;" but they are not altogether thankless, for their looks and their actions on this occasion expressed unmistakable gratitude.

From information gained from Mbame and others, it seemed that the neighbourhood of Mount Zomba was the theatre of the war ; and as it was probable that the emissaries of the Portuguese were up there with a view to reap the iniquitous harvest of slaves, Dr. Livingstone determined to go up there also.

Procter, and Scudamore, and William were left in charge of the released slaves at Soche's village, which was more favourably situated for their support and safety than that of Mbame, 
and the Bishop and all the rest went with the Doctor to Mount Zomba.

It was evident that the armed party who crossed the river the day before knew nothing of these proceedings, and as they had taken the route to Soche's, we were anxious for the safety of Procter and Scudamore.

Anxiety gave me fever. I was ill for several days. Chechoma was much concerned, and came frequently to inquire after my health. I was impatient to get my house built-fever always makes you impatient-and he seemed to understand this ; for when I spoke to him on the subject, he replied as to a child who was fretting because he could not immediately have the thing that he wanted.

"Wait," said he, "wait but a little-three days-two daysone day-who can say? But suppose you wait three days; what are three days in the building of a house?"

The men returned on July 28 th, and Chibisa's answer was, "The white man is a good man; he is my brother. If he wants to build, let him build. If he wants to stay, let him stay. If he wants to leave his ship and his goods behind him while he goes about the country, let him leave them, and let my people see that no one touches them."

These men also told us that the armed band which had made us anxious had recrossed the river, and that they had brought us a message from the Portuguese man to the effect that he had done no harm, he had committed no violence, he had made no slaves, he was going back to Tete, and there was, therefore, no cause of offence between him and the English.

From information which we afterwards obtained we learned that this man had gone to within a short distance of Soche's village, and having heard what Livingstone had done, and that there were English in the village, he had taken fright and retreated. Had he not been checked in his career, he would probably have caused widespread misery, and have returned with hundreds of slaves.

The 28 th was Sunday, and early next morning $I$ went to the village to make arrangements for the building of my house; for, despite the Bishop's hint that I might be wanted on the hills, 
I hoped that I might remain at Chibisa's. I found the Chibisians either drunk or getting drunk. I was half prepared for this, for the uproar during the night had been great. The return of the messengers was the excuse for this dissipation. My reception was most hearty. I was their brother; Chibisa had said it. They would do anything for the English, and we might do what we liked in the land; had not Chibisa said so ? Much pombi had been drunk, and there was much more to drink, so I declined any assistance from them for that day.

No further news came from the hills for two or three days. and I and Gamble, who had recovered strength, worked hard at our house, the timber and other materials for which were supplied by the Chibisians. But about midday on August ist I heard the firing of guns on the other side of the river, and was informed that Dr. Livingstone had returned. The Chibisians were in a state of great excitement; for amongst others who got into the boats were two men with the slave-forks on their necks. I said that they were Chakundas (and so they were), and my friends clapped their sides in amazement, if not with satisfaction. Verily strange things were coming to pass in their days.

I went over to the Doctor, and found that, with the exception of a sailor named Hutchins, who was left with the Bishop, all the people belonging to the expedition had returned. From the Doctor at that time, and from others afterwards, I learnt what had been done after July $\mathrm{r} 8$ th, when they started from Soche's village for Zomba.

On that day they marched about twenty miles to Mongazi's village, where they surprised two Chakundas, made them prisoners, took from them their guns and baggage, and freed five women and two boys. The Chakundas managed to escape during the night, and the old chief, Mongazi, undoubtedly contributed to their escape; for he was indignant that they, his guests, had been so unceremoniously treated, but was afraid to offer any resistance to the Doctor's proceedings.

On the Igth an excursion was made into some neighbouring villages, and eight women and children were rescued, but the Chakundas succeeded in escaping. 
The whole party then left Mongazi's and went on to Magomera without meeting with any more slave-dealers. The people were fleeing in terror from the neighbourhood of Magomera, and Chigunda, the chief, said that the Ajawa were close at hand, and were burning, and killing, and making captives.

On the 2oth, Chigunda, in order to prove that his words were true, offered to show the English the Ajawa camp, but Dr. Livingstone was not well that day, and so all remained at Magomera. The object of the Bishop and his party in coming into the country was made known to Chigunda, who said that most of the villages about him where deserted, but if the Bishop would live with him he would not run away.

The 2 Ist, being Sunday, was also spent at Magomera. During the day continual reports were brought to Chigunda of the near approach of the Ajawa.

On the $22 \mathrm{~d}$ the whole party left for Chinsunzi's, where the Ajawa were said to be in strength. On their way they heard that some Tete slavers were in the neighbouring villages, and having started in pursuit of them, they succeeded in releasing over fifty slaves. With the exception of two, the slavers escaped, and because these were insolent their necks were put into the slave-forks that had just been removed from the necks of their captives, and were kept in them until, as I have mentioned, they were brought down to the Shire.

The slave-fork is a terrible tamer. As an experiment I put my own neck into one, and found the helplessness of my condition complete.

The $23^{\text {rd }}$ was an eventful day. Dr. Livingstone, the Bishop, and the rest of the English party, with the exception of two, who were left in charge of the freed people, made for the Ajawa encampment. A considerable number of the Manganja went with them. Everywhere on their journey they saw sad signs of the war,- -burnt villages, deserted gardens, and a land bereft of its inhabitants. About midday they came upon a large party of the Ajawa, who were returning from a successful raid. The smoke of burning villages was seen in the distance. A iong train of captives carried the plunder, and their lamen- 
tations were heard above the triumphant cries of the Ajawa women, who came out, like the Israelitish women of old, to welcome back the victors. The Ajawa camp, which consisted of a great number of hastily constructed huts, was on the slope of a hill, and so flanked by other hills as to make it almost safe from the assaults of native enemies. Dr. Livingstone and his party went on cautiously, and succeeded in getting quite close to the camp before they were discovered; then the Ajawa came forward, and concluding that they had to deal with enemies, shouted out words of defiance, and behaved like men intoxicated with previous success and confident of victory. The Doctor called out that he came to talk with them, and that it was peace, not war; but they gave no heed to his words, and replied that it was war, not peace, and prepared for the battle. At this juncture, Johnson seeing a man aiming apparently at the Doctor, raised his gun and fired. Then the fight began. The Ajawa, after delivering a few volleys of arrows, during which their shouts of derision rent the air, charged down upon the English as though they were confident of being able to sweep them away. But being met by a few rifle-shots, they halted, and then sought the cover of trees and rocks. Finally, they were forced to retreat, and their camp was destroyed. No Englishman was hurt; one Manganja man was killed, and another was wounded in the wrist by an arrow. The Bishop was in the midst of the fight, but took no part in it.

On the 24th, the English party returned to Magomera, where Dr. Livingstone had arranged to meet Chinsunzi, one of the principal chiefs of the neighbourhood.

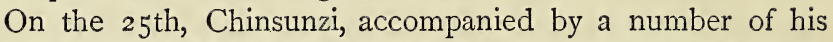
people, came to Magomera, and the Doctor explained to them that though they had seen the English as fighting men, yet it was not as fighting men they wished to be known. They were men of peace, and did not come to fight, but to teach them about God, and to promote good-will between man and man, and tribe and tribe. But finding the Ajawa were burning the villages, and killing and making captives of the inhabitants, he and his friends had gone to stop them. If they profited by 
the lesson they had received and would live at peace, he and his friends would rejoice and become their friends. He then told them that he was going away himself, but the Bishop and others would stay at Magomera, and make it a strong place, to which women and children might flee when in danger.

Chinsunzi was not satisfied that we should stay at Magomera; he wished to have us at his own village. The Bishop was strongly in favour of making Soche's village our headquarters, but Dr. Livingstone urged that Magomera would be the best place for us, as it was near enough to the Ajawa to afford protection to those who needed it, and yet was removed from the possible scene of conflict ; by staying at Magomera, he said, we should save the whole country between it and the Shire; and so it was decided at length that we should make our first station at Magomera, which was about seventy miles from Chibisa's.

Dr. Livingstone brought me a letter from the Bishop which ordered me to come up to Magomera as soon as possible. Johnson came down with the Doctor in order to act as my guide.

I left Chibisa's on the morning of August 5th. The engineer and the quartermaster of the ship accompanied me for their health's sake. I had secured the assistance of over seventy bearers, for by this time I had gained the confidence of the Chibisians. I took down all their names, and made their engagement with me quite a formal business. There was no confusion or wishing to return to the village this time; every man was ready with his load when I called out "Atiendi" (come on), and by half-past ten we were well on our way to the hills. The path did not admit of two abreast-none of the paths in this part of the world do-so we formed a long line walking in Indian file.

After we had gone over the ground I had previously traversed, we entered a mountain pass. For three or four miles the walking was easy, and the hills on both sides were well wooded and pleasant to look at. Then the path became rugged, huge masses of rock strewed the ground, and we began to ascend rapidly. The Kubala was here no longer a peaceful stream, as 
in the valley, but a dashing mountain torrent, which we had to cross many times as we best could.

We continued our journey for about four hours, and then halted. Of my rear I could see nothing, for the path was circuitous, and the hills were thickly wooded. It was nearly an hour before the last man came up. The view from where we rested was magnificent. We looked over hills whose summits and slopes were covered with trees and bamboos, which exhibited a verdure everywhere beautiful and everywhere varied, and beyond them we saw the valley of the Shire in its actual breadth from the foot of the hills whereon we stood to the mountains that shut in the Zambesi. It was a sight to dream about.

The sun was nearing the horizon when, to our great relief, for we were all very tired, we caught sight of our resting-place for the night-a village which lay at the bottom of a deep basin-like valley. We were courteously received by the head man, who placed two of the best huts at our disposal, and who also desired his people to supply us with what we needed.

As the bearers came up, I made them bring their burdens to me, and had them put into the hut which I intended to occupy. Then I divided the men into parties of twelve, and gave to each party a fathom of cloth with which to buy food for supper and breakfast. By the time this was done Johnson had our dinner ready; it consisted of the hind quarter of a goat, a yam, and green peas; and before we had finished eating, the Chibisians had a dozen fires lighted around us, and as many pots on them.

The sun was lost to us sooner than it would have been in the Shire valley, but for some time its rays illuminated with a ruddy glow the cloudlets above us, and gave to the mountains that surrounded us a touch of beauty that abides in the memory. As the darkness increased the fires of our black friends were multiplied, and lighted up their faces, as, eating and drinking, they made the hills reverberate with their laughter. I had. no heart to check their merriment, though it lasted far into the night; after their hard day's work it was pleasant to find them so cheerful. 
The inhabitants of this village looked well fed, but they were miserably clad, most of them having nothing around their loins but a wrapper made of the inner bark of a fig-tree, which they soak and otherwise prepare, and beat out with mallets until it is as thin as coarse calico. It is the badge of poverty, and it makes the wearers look poor indeed.

We were off early on the morning of the 6 th, and made our first halt at Mbame's, which was situated on the edge of the first plateau or terrace, which is about ten or twelve miles broad, and is well wooded, well watered, and fertile, and with an atmosphere that, after the hot air of the Shire valley, seemed very refreshing.

Mbame was a stout old man, grey-headed and hearty. His village was well built, and the inhabitants looked as though they had never known what hunger was. We rested for a couple of hours, and then went on to Soche's, which we reached about 4 P.M. This village was situated at the foot of a hill about 3000 feet high. It was surrounded by banana trees, and the country round about it seemed capable of producing an abundance of all good things. Provisions were plentiful, and a better fed but a more dirty people I had not seen.

Soche himself was not a pleasant man to look at; he put one in mind of a man who had committed some great crime and lived in the fear of being found out. Nevertheless he gave us a cordial welcome, and told me that I might have whichever hut I liked; the one I had was dirty and full of vermin.

When the goods were stored, I paid the bearers and gave them cloth for food; and I never paid anything with greater satisfaction, for they earned their wage well and truly. They left for home early in the morning.

Soche behaved admirably, and gave orders to his head man to collect as many bearers as we needed. This functionary did his work so well that I procured a man for every burden.

The distance from Soche's to Mongazi's is about twenty miles. The country was not rugged and the paths were good. For the first two hours our road lay through the Pingwi and Bangwi pass, which was a valley of flowers. The mountain 
scenery beyond was grand. Huge basaltic hills from rooo to 5000 feet high rose from a vast plain, not in ranges, but apart from one another; but the plain was flanked on the south-east by the Milanji, a range of mountains whose highest summit was probably I 5,000 feet above the sea.

We halted for a rest when we were fairly through the pass; but we had not been resting more than five minutes when the roll of distant thunder warned us of an approaching storm. In a few minutes more we saw the rain-cloud on the crest of the mountains fill the gorge behind, and then roll on toward us. We hoped that the storm would exhaust itself before it reached us, but it did not. The rain overtook us, the lightning nearly blinded us, the thunder leaped from hill to hill, and in the course of a short time the country about us was trembling under the strife of the elements.

It did not cease raining until we arrived at Mongazi's, about 4 P.M. Mongazi was an old man, tall, lean, and ill-looking. His arms were laden with brass rings, and he wore a scarlet cloth. He professed to be greatly pleased to see us, and he certainly was astonished at my long train of bearers, and the wealth which they were supposed to carry.

I paid Soche's men as they deposited their burdens, saw that they were supplied with food, and then began to think of myself; and it was time, for I was shaking with fever. So I took a doze of quinine and hoped that I should be all right in the morning; but I was not; the fever was strong upon me, and I could not walk without staggering. Nevertheless, I determined to get on to Magomera; and having procured bearers, we proceeded on our way. It was about two o'clock when we reached Magomera, the sight of which stimulated me, and for a time freed me from the sense of fever and fatigue.

Magomera, however, was not a large village, nor was it so pleasantly situated as Soche's or Mongazi s. Approach it from what quarter you might, you had to descend to it. The principal part of the village was on a peninsular-shaped bit of land, about eighty yards broad by about three hundred long, which was formed by the course of a small river that took its rise I knew not where, and flowed I knew not whither. It was here 
that Chigunda lived, and it was here that the Bishop had established himself and his now numerous family. A stockade had been erected under Waller's superintendence right across the entrance to the peninsula, so that by stockade, river, and trees the place was quite enclosed. Dr. Livingstone thought it a place that might be easily defended; it certainly would have been difficult for the Ajawa to get into it, but it would have been equally difficult for us to get out to them. An attack from the Ajawa was expected; no one had left the enclosure without being armed, and a watch had been kept every night. The mission party being short of guns, Dr. Livingstone sent up four muskets with the necessary ammunition, and also a couple of rockets.

When I entered the gate the village seemed to be swarming with life; children were running about everywhere, and there was quite a crowd of men and women. On the right a large house was in course of erection, from which the Bishop came and gave me a loving welcome. Scudamore then appeared, axe in hand; he had been felling trees. Procter was at work in the house, and Waller I saw lower down surrounded by a number of people. From all I received so hearty a welcome that I felt I was indeed amongst brethren. Then Chigunda came up and shook hands. He was a mild, intelligent-looking man, about thirty years of age, of middle height and spare habit.

After I had paid my men I was obliged to lie down in the Bishop's hut, for the fever again made itself felt ; but the satisfaction of having successfully accomplished the journey far outweighed the inconvenience which the fever caused me, and I was very happy. 


\section{CHAPTER IV.}

$\mathrm{N}$ the day when I arrived at Magomera most of the chiefs of the country had arrived there also; they came to solicit our aid against the Ajawa. Ever since Dr. Livingstone had left, chief after chief had come to the Bishop for the same purpose; now they came altogether. Dr. Livingstone thought that what he had done would be sufficient, but he knew not that there were other bodies of Ajawa in the land, who were doing just what those did whose camp he destroyed, and that unless something was done to check them, they would soon overrun the whole country. It was natural that the Manganja should come to us for aid, considering the action which the English had already taken against their enemies.

The formal conference on this subject began soon after I arrived. The chiefs assembled close to the Bishop's hut. Chinsunzi and Kankomba, the two greatest men in the neighbourhood, sat alone. Chigunda, who was to act as speaker, sat between them. Behind these three sat about one hundred and fifty others, most of them being men in authority; they were the governing body of the country, in fact. The Bishop, and the rest of the mission party who were associated with him on this occasion, sat on a mat facing the assemblage, and William acted as our interpreter and speaker.

Chinsunzi and Kankomba said but little, but the others said much. One after another stood up, and after bowing lowly to one or the other of the two great chiefs, commenced to speak by saying, "I follow my lord Chinsunzi," or "I follow my lord Kankomba." They were encouraged while speaking by a regular chorus of approving ejaculations from the rest. When 
each had done, Chigunda repeated what had been said, commencing his recapitulation with "Ati" (he says); and his accuracy was rewarded by expressions of approval. All the speeches were uttered in a high-pitched voice-they were intoned, in fact ; indeed the natives of this part of Africa always intone their speeches, and their prayers also. The speakers described the happy state of the country before the Ajawa came into it, and its misery and desolation afterwards. They told of villages burnt, of brethren slain, and of wives and children carried away. And they concluded by describing the happy state of things that would again exist if the English would only help them against their cruel enemies. The oratorical power of the speakers was great. I could not understand what they said, but I felt it, for their voices and gestures were in perfect harmony with their subject. After hearing all that they had to say, the Bishop told them that in three days he would give them an answer. We all felt the gravity of the position in which we were placed, and did not approach the consideration of the question upon which we had to decide with a light heart.

Dr. Livingstone had informed us, and the Manganja people supported his view, that the Ajawa that had invaded the Manganja country were a mere slaving horde in league with the Portuguese slave-traders; consequently we did not, we could not, look upon the conflict between them and the Manganja as a mere tribal war that had been provoked by ordinary tribal differences. In such a war we should have no right to interfere save as ministers of peace. But regarding the Ajawa from the only point of view that was then possible to us, we felt that, though pre-eminently ministers of peace, we should do no wrong, and might do much good, if we acted towards them as ministers of justice. Without our aid the Manganja were certain to be destroyed, for there was no real bond of union amongst them. This arose from the fact that they were a purely agricultural people, and were broken up into inconsiderable sections. Small villages were scattered over the country; each village had its head man, and each district its head chief; but the tendency of each little community was to care for itself 
only; there was no great principle, no real feeling of patriotism to unite them in defence of their country, and so when the enemy came, they were destroyed in detail, for rarely did they combine in sufficient numbers to repel the invaders. Each seemed to care but little for what befell his neighbour, so long as he himself remained unmolested. But they were willing to unite for the common good under our leadership, and the question was, should we lead them or leave them to perish ?

On Sunday, August IIth, having received the Holy Communion, we consulted together upon the answer we should give the chiefs on the morrow. We took into consideration the extraordinary position in which we should place ourselves with the Church at home, and every other circumstance that seemed to bear upon the subject we had to decide upon; and we were unanimous in thinking that we should be warranted in giving the Manganja the aid they solicited, if they agreed to certain conditions that we intended to propose to them. In coming to this resolution we had but one object in view-the promotion of God's honour and glory in that land.

About two o'clock on the I 2 th, Chinsunzi, Kankomba, and many others assembled to hear our decision. Before we went to them, the conditions we intended to propose for their acceptance were reconsidered, and then the Bishop prayed that God would prevent all that was not in accordance with His will, would guide us aright in this and in all that we did, and that $\mathrm{He}$ would promote the knowledge of Himself and of His Christ amongst the people to whom His providence had guided us.

When we appeared, all the chiefs arose and saluted us, bowing their bodies and clapping their hands. This time it was we who had to talk, and so the conference did not last so long as on the former occasion. William, who seemed to be quite a master of the Manganja language, acted as interpreter.

The Bishop commenced the proceedings by telling the chiefs that all their sorrow of heart and misery were caused by the slave-trade, in which they had themselves engaged, and 
said we would help them if they agreed to the conditions we were about to propose.

Kankomba, on behalf of the rest, replied that they would listen to the Bishop's words, and if they were good they would agree to them.

The Bishop then proposed :-

I. That all the chiefs then present should solemnly promise, on behalf of themselves and people, that they would not buy or sell men, women, and children again.

After some moments of silence, a deep "Aye" came from the assembly, and Kankomba said the words were good and they all agreed to them.

Then the Bishop proposed:-

2. That all captives found with the Ajawa should be perfectly free; that no chief or person should claim any one of them, but that they should have the liberty to go to whom they liked and where they liked.

These words were also pronounced to be good, and as such were accepted.

Before putting the third condition, the Bishop told them that one of the objects of our presence in the land was to put an end to the slave-trade, and that we could not look upon those who engaged in it as our friends ; therefore he proposed-

3. That all the chiefs present promise that they will unite to punish any chief who sells his own people or the people of any other chief, and that each chief will punish any of his own people found guilty of buying or selling men, women, and children for slaves.

To this they all bound themselves; and then it was proposed-

4. That if any Portuguese or other foreign slave-dealers came into the land, they would drive them away, or at once let us know of their presence.

And all said "Aye" to this.

After which the whole assembly stood up, and again solemnly bound themselves by the conditions we had proposed.

Then the Bishop told them that we would help them 
against the Ajawa, because after their promises to us we felt that we should be doing right.

It was arranged that we should all meet at Chinsunzi's the next day, the headquarters of the Ajawa being, it was declared, not far from there, and that we should go against the enemy the day after.

We were deeply sensible that we had bound ourselves to do a very unusual thing; but we all felt that the circumstances in which we were placed justified the doing of it, whatever might be thought of our conduct at home, where law and order were maintained by a regularly constituted and efficient executive. We concluded that it was more Christian to punish the aggressor and succour the oppressed than merely to defend ourselves, and more prudent to make an attack upon our station impossible than to wait quietly until we were attacked and those we had taken under our care were placed in peril. At no one moment did we forget that we were Christian missionaries, and we did not under all the circumstances see that what we proposed to do was inconsistent with that fact.

It was settled that Procter, Gamble, and William should stay at the station in order to take care of the freed people and look after the "stuff."

On August I $3^{\text {th }}$ we accordingly set off for Chinsunzi's. For a few miles Chigunda marched at our head with the gait of a man who intended to do great things, and then he was nowhere to be found. Zachuracami, his head man, said he would come on in the morning, but he did not. Our path lay over a fertile, well-wooded plain, thickly studded with villages, and leading directly towards Mount Zomba.

$\mathrm{We}$, of all the confederates, were the first to arrive at Chinsunzi's. The village was larger than Mongazi's and well built. It was, however, deserted of its inhabitants and looked desolate. Soon after our arrival Chinsunzi came from his hiding-place in the bush. He explained that all the women and children were in hiding and that his men were scattered about, but would be in before nightfall. He then went away, after showing us to his own hut, which was fully twenty-five feet in diameter.

A party of Kankomba's men soon afterwards arrived, but the 
chief himself came not. Other bands quickly followed, and by sunset at least five hundred men were encamped in the village. About fifteen of them had guns, but none had ammunition. Some of the guns had the elephant, the East India Company's mark upon them, while the G.R. and the crown showed the British origin of others. These guns had been brought into the country by slave-traders.

It was a strange sight to see these men looking outwardly very like warriors, with their guns, and spears, and bows and arrows; and had they felt like warriors they would have been more than able to protect themselves against any number of men the Ajawa could bring against them; but they belonged to a timid race, and kept their fears of the Ajawa lively by telling each other unfounded stories of their prowess.

As Kankomba did not appear, we sent for Chinsunzi, who was all activity amongst his own men, to inquire the reason; when, to our surprise, we learnt that it was not the custom of the Manganja chiefs to go to the battle themselves; that he, Chinsunzi, would not accompany us on the morrow, but, like Kankomba, would send his son as his representative. $\mathrm{He}$ fetched his son, and also his head man, who looked brave and resolute, and pleased us.

Before I lay down for the night I went out into the village. More men had come in, more were coming. Every precaution had been taken to keep the expedition secret; and though there were nearly a thousand men in the village, they made no noise, but sat round their fires in silence; or only spoke in whispers.

On the morning of the I 4 th we were up by four o'clock, and after prayers and breakfast went forth to our allies. Chinsunzi had been amongst them all night, and they were all ready for the march ; not crouching round their fires, as their manner is on ordinary occasions, but standing round them, forty or fifty in a circle, with their weapons in their hands. I went amongst them to see what spirit they were of: they seemed cheerful and confident, but their confidence was evidently in us rather than in themselves.

We English were eight in number, viz., the Bishop, the Rev. H. C. Scudamore, myself, Waller, and Adams-these 
belonged to the mission; Hardisty, the engineer; Gwillim, the quartermaster; and Hutchins, a sailor-these belonged to the expedition. Johnson, our black cook, and Charles, one of the Cape men, completed our party.

When we gave the order to march, for a few moments great disorder prevailed. The exit from the village admitted but of one abreast, and all rushed forward and blocked up the way. Kapanji, Chinsunzi's son, and the head man exerted themselves vigorously, however, and order was re-established. We then went out first, and the rest followed in single file under the command of their respective leaders.

As daylight increased we saw that we were marching directly towards Mount Zomba, for the Ajawa camp was at Chirumba, immediately under the southern side of the mountain. After we had been on the road about an hour we had a view of Lake Shirwa, and a beautiful view it was.

As we went along other parties of Manganja who were waiting on the roadside joined us, so that we were more than a thousand strong.

About eight o'clock we halted at the foot of a hill, from whence Kapanji told us we could see the Ajawa camp, and here the Bishop resolved to ascertain what the position and strength of the Ajawa were. But before ascending this hill he called us Christians around him, and we knelt down, and he prayed that God would be with us in what we were about to do; that He would incline the Ajawa to go away peaceably; if not, that $\mathrm{He}$ would give us the victory ; and that He would for Christ's sake forgive the sins of those who might fall that day, whether white or black, friend or foe.

I should mention here that the Bishop had resolved to seek a conference with the Ajawa chiefs, in order to induce them to leave the country peaceably.

I did not go up this hill, as it was better for one of us to remain with the Manganja to keep them in the order in which they arrived. It was nearly an hour before the Bishop returned. He had had a good view of the camp, which he reported to be very large, but easily got at.

We resumed our march, and in another hour we were on 
rising ground close to the encampment. Right in front of us was Mount Zomba, and between us and it were the Ajawa. Their strongest position was a hill about two hundred feet high, the possession of which would enable us without much difficulty to drive them from the field.

It was not long before the Ajawa perceived us, and as soon as they saw us they set up their war-cry. Such a horrid discord of human voices I hope I may never hear again. Crowds of people of both sexes ran towards our left, where we supposed the chiefs were, and a considerable number of men took up a position on the hill I have just mentioned, or dispersed themselves in the bush that lay between us and it.

Notwithstanding this warlike demonstration, the Bishop and Waller, accompanied by Charles to act as interpreter, went down to the camp unarmed, and made for what they supposed to be the headquarters of the camp. They were met by four men, two of whom were armed with guns. The Bishop told them that he had come to have a peaceable talk with their chiefs, and desired that they might be fetched to him. This they refused to do, and asked what sort of white man he was; and upon being told English, they said that they would have nothing to do with the English, for they were enemies, and had helped the Manganja against them only a few days before. They then came forward as though intending to attack, but the Bishop held up his hand and bade them stay where they were; and this they did, waiting to hear what else he had to say. $\mathrm{He}$ repeated that he came with a message of peace, but if they would not listen, it would be war, and he again desired them to call their chiefs. The chiefs answered, it would seem, for themselves, for a cry came from their quarter, "Shoot them! don't listen to them!" So finding further efforts at peace useless, the Bishop and Waller and Charles returned, closely followed by the men with whom they had been talking, and expecting every moment to be shot at.

They were away from us about a quarter of an hour, and it was a great relief to all when they returned unharmed. Their first words, uttered by Waller, were, "It is war! They will not have peace ; they will have nothing but war with us." 
And they had it. In a very short time they were driven away and their camp was destroyed.

So far as we could learn, no one on our side was killed or hurt, and very few on the other; for the Ajawa fled in superstitious fear when they found how far our rifles would carry; and when they retreated, we allowed them to go away unmolested. We English got separated during the conflict, but we all met together again at Chinsunzi's. The Bishop came in carrying a baby that had been thrown into the bush, and followed by a crowd of women and children whom he and his party had picked up.

After prayer and thanksgiving, we sat down to dinner, having been without food for sixteen hours, and having marched at least thirty-five miles.

After dinner the Bishop went out to see if the people he had received were properly taken care of, and when he returned he brought a little child with him, a boy about six years of age. This little fellow was found at the door of a hut, and was so ill that the natives shook their heads, and said it was no use to remove him, for he was dying. He was a Manganja child, a cartive probably, who, because he was ill, had been left to starve and die. He was fearfully emaciated, and life was evidently fast ebbing away. We tried to rouse him, but our remedies produced only a momentary effect, and the Bishop decided upon baptizing him. So this poor child, under the name of Charles Henry, was numbered amongst the children of God, and in two hours afterwards his spirit was in Paradise.

When I awoke in the morning the first thing I heard was the voice of a male child. It had by accident been shut out of a hut. Waller heard its plaintive cry, fetched it in, and made it happy for the night under his rug. And there it was, a mere babe, chatting away to him by the side of the fire, and not at all afraid. .

After breakfast all the people that had been taken by the Bishop or others were assembled in front of our hut ; Chinsunzi and a great many Manganja were also present.

The Bishop reminded the Manganja that we had agreed that all captives found with the Ajawa should be at liberty to go 
where they pleased, and he told them that he was now going to give them that liberty. We were then informed, to our surprise, that some of those that had been brought in from the field were Ajawa people. We had not dreamt of making captives, so we had made no stipulation respecting those who were in the position of captives. But the Bishop soon decided what to do.

First of all he inquired if there were any Manganja present who had been made captive by the Ajawa, and about a dozen women and as many children stood up. Most of these had relatives or friends then present, and they were told that they might go to them there and then. It was a happy sight to see what we then saw-the reunion of husbands and wives, of brothers and sisters, and of fathers and children.

Then we divided the remainder into two parties,- those that were Ajawa, and those who, though not Manganja, had nevertheless been made captive by the Ajawa. It then appeared that there were about forty Ajawa women and children present, and that the rest, about twenty-five, belonged to the Anguru, a tribe whose territory was in the neighbourhood of Lake Shirwa; these people, however, had been living with the Manganja, and had shared their fate. To them we gave the same liberty of choice that we had given to the Manganja, and they all found friends present to whom they elected to go.

We gave no choice, however, to the Ajawa women and children. They had no homes to which they could at that moment return, and we did not think it right to leave them with the Manganja, who might have ill-used them; so we resolved to take them to Magomera, keep them until they could understand our true feeling towards them, and then send them as ambassadors of friendship back to their own people.

Our march home was an anxious and a slow proceeding. We hired men to carry the small children, but some of the women were lame. For a little girl named Dauma no carrier could be found, so, after she had trudged along some distance, the Bishop shouldered her and carried her into Magomera.

Next morning the Bishop told the Ajawa people that we had brought in from Chirumba his reasons for not leaving them at 
Chinsunzi's. They said that they would sooner be with us than with the Manganja.

They were very badly off for clothing; indeed some of the women were not decently clad, even according to the native notion of decency; so we gave to each woman a length of cloth and made all the children presentable. They were evidently astonished by this liberality; but their astonishment was greater when Waller, who happily knew a little of surgery, and who then acted as our doctor, called to him those who were ill-for many of them were suffering from grievous ulcers -and washed and dressed their poor diseased bodies.

The Bishop appointed me to take care of the stores, and to buy food, and to distribute it to all who were dependent upon us. I had a large family to provide for and satisfy, for there were more than two hundred of them. Provisions, however, were plentiful; and when the Manganja found that we wished to buy, they were very willing to sell. That part of the highlands in which we were was a lean land as far as animal food was concerned, for the population was great and the wild animals had been driven into the less peopled districts, and the only domestic animals fit for food which the Manganja had were sheep, and goats, and fowls : the last were found in every village, but sheep and goats were scarce.

The natives themselves lived almost entirely on vegetables. They grew several kinds of corn, the principal of which was the maize or Indian-corn, and peas, beans, pumpkins, melons, sweet-potatoes, cucumbers, cassava, yams, ground-nuts, and bananas.

To all the people who came to us with food for sale-and soon very many came-we told our object in coming to them. For a time they distrusted us ; the women would keep outside the stockade and send their male friends with the barter; and they invariably came without their children. Then two or three women would come in together; then they brought their babies; and at length, when they found that we never deceived them, never harmed them, but always sought to do them good, they gave us their entire confidence, and their children came to us without hesitation or fear. Indeed, we soon found that the 
land was open to us, for go where we would into the country about Magomera we were cordially welcomed and hospitably entertained.

But beyond food there was scarcely anything else to be purchased. We had thought to find cotton in abundance in the highlands, but though we inquired for it wherever we went, we could not get five pounds weight of it. It was grown to a larger extent in the Shire valley, but though Livingstone offered more for it than it was worth in the Manchester market, he failed to get as much as a bale. That it could be grown extensively in the Upper Shire valley I do not doubt, but I doubt very much indeed if the Shire highlands were suited for its growth. The natives said it would not grow there, and that when they wanted cotton to make themselves a cloth-for they have a weaving apparatus like that of the ancient Egyptians-they procured it from the valley in exchange for iron.

There seemed to me to be no opportunity of carrying out one part of our programme-the encouragement of a lawful commerce-for the raw produce of the country, from a commercial point of view, was, as far as we could discover, quite insignificant. I have no doubt that these highlands could be made more productive, that tobacco might be largely cultivated, that many things which grow elsewhere might be grown there, and that many things which grow there might be improved and more largely grown; yet with regard to agriculture we soon discovered that the natives could teach us more than we could teach them, and that we could offer them but little inducement to grow more of anything than they needed for themselves. So another part of our programme, the encouragement of agriculture, was virtually a dead letter.

Some other surprises were in store for us; for soon after we were settled at Magomera we discovered that three-fourths of the people that were living under our protection were Ajawa; that most of those that had been released from the slavers were Ajawa, some of whom had been sold by their own friends, but the greater part by the Manganja. The Bishop told them that if any of them wished to go away from us they might do so, 
but that he should not like them to go away by stealth, as if they had been treated unkindly or were not free. None, however, expressed a desire to leave, and one woman was quite eloquent in the expression of her desire to remain. "Where shall we go ?" replied she. "Our homes are gone, our friends are gone, we have no safe place anywhere. You (the Bishop) are our father; you give us all we need, you treat us kindly, we are not slaves, and we will not go from you unless you send us away. We see that it is good to be with you."

The evil of crowding so many people together on so small a plot of ground as that which we occupied was soon apparent in more ways than one. While they were herded together like pigs it was useless to think of improving their moral-condition; and as soon as we had got rid of the fear of an attack from the Ajawa, the Bishop resolved to have huts built for our people outside the stockade, and to make an effort at the same time to raise their standard of life. He called them all together, therefore, and having pointed out the ground that was to be built upon, told them that if they lived with us they would have to obey our laws.

"That is good," was the reply. "You are our father now, and we are your children. It is for the father to make laws, and for the children to obey them."

"I am glad to hear that," said the Bishop. "So bear in mind that henceforth you men must live by yourselves, and you women by yourselves."

"Is that so?" rejoined they in great astonishment. "And is that the custom of your country?"

"No," said the Bishop, "it is not; and if any one man wishes to have any one woman for his wife, and she is willing to take him for her husband, we shall not object to that."

"What! and only one wife?" asked the men. And upon the Bishop replying, "Only one," they naturally asked if that was the custom of his country, and wherefore. The Bishop then told them that it was, and because we had God's Word; that our custom was more in accordance with God's Word than theirs, and that we obeyed God's Word because men who did not were not so happy as those who did. He begged them to 
listen to us, and assured them that if they did, it would be for both their present good and their future welfare.

They discussed this question amongst themselves for some time, and then one answered for all. Said he-

"It is very certain that you are not enemies. No enemy would do as you have done. When the Chakundas (slavers) were taking us away you set us free; when we were naked you clothed us; when we are hungry you give us food; if we are sick you give us medicine. No enemy would do that. You must be friends. And as you know more about God than we do, let it be as you say."

And so it was arranged.

A day or two after this conference a young man came to us while we were at dinner, and sat himself down in front of us without speaking. Said the Bishop, "What do you want?"

Said he, "I have come to have a little talk with you."

But though he came to talk, it was the very thing he did not do, and that surprised us. Our friends were eloquent talkers; there seemed to be established between their brains and the tips of their tongues a perfect bond of sympathy, so that with them thought and speech were twin-born. But we could not get a word from this man; there was evidently something on his mind which disturbed his spirit and made speech difficult to him. At length the Bishop said-

"Tell us what you want or go away."

Then he evidently with a great effort replied-

"I want-I want So-and-so for my wife."

When asked if she wished to have him for a husband, he held down his head and said, "She says so."

And when he brought her to us she did say so. Then the Bishop, William acting as interpreter, spoke to them very gravely upon the duty of husbands towards their wives and the duty of wives towards their husbands, and made the man promise that he would have no other wife while this one lived, and the woman promise that she would have no other husband; and made them both promise that they would be kind and faithful to each other; and ended by making him solemnly promise that he would never sell her. After this they were 
told that we regarded them as man and wife, and were shown where the village of the married people was to be, and bidden to build a hut for themselves.

Next day we had several candidates for matrimony. One man, however, brought up a woman about whom he had made a very great mistake indeed; for when she was asked if she was willing to have that man for her husband, she broke out into a torrent of abuse against him, and declared that she was not. He went away greatly angered, but in the course of the day, in order to prove to us, I believe, that he was not such an undesirable fellow after all, he came back with two women, both of whom were anxious to be wedded to him.

After this marriages became popular, until all the men were provided for. Unfortunately we had more women than men, and quarrels as a consequence occasionally took place. The wives began to value their prerogative, and would not quietly permit any other woman to share in their husband's affections, although up to this time they had been accustomed to the arrangements of polygamy. In the end, however, these people lived happily in their new conciition, and as a rule they were kind and faithful to one another.

It was thus we sought to lay the first foundation of a Christian community. We commenced with the first principles of morality, and hoped in course of time to lead them to that knowledge of the true God which is eternal life. But our position as missionaries was complicated by our action against the slavers and the Ajawa. We said again and again we came to teach and not to fight, but it was as men of war that the natives persisted in regarding us. As such, our reputation was great, even to absurdity. We were looked upon as the possessors of supernatural power, and it was not long before we learnt that the natives believed that we had a war-medicine (fetish) that made us irresistible. I once had a remarkable confirmation of this. Some time after we had settled in the land I went to the village of Mankokwe, the Rundo, who at that time was anxious to be friends with us. Our doctor, Mr. Dickinson, whose arrival in the country I shall presently have to speak of, was with me. While talking to the chief he suddenly became very affectionate, and 
pui his arms around my neck, and I felt sure he was going to ask me for something, for human nature in its broad features is very much the same amongst all races of men. Said he at last-

"Is that your medicine-man?" pointing to Dickinson. I assented.

"Ask him to give me your war-medicine."

I laughed and told him that we had no such thing.

"That is not true," said he ; "you have, you must have, and you do not like to give it me ; but do ask him for it."

"I speak the truth," said I. "We English have no other medicine than a brave heart."

He did not believe me, and replied-

"No, that is not true ; it cannot be true. I have a brave heart; all my people have brave hearts. But brave hearts alone are no good. For when we go to fight the Ajawa, directly we see them we all run away. Why is that? Not because we have not brave hearts, but because the Ajawa have stronger war-medicine than we have. Now you have stronger warmedicine than the Ajawa, so strong, that if only one English. man went against them they would all run away. Do not be an ungenerous man. Ask him to give me your war-medicine."

Such a feeling as this, I have no doubt, spread at once through the land. If men or women met us in the paths, they would kneel while we passed and say, "Ah, my master!" or "Ah, my lord!" Things that we had with us, of whose nature they were ignorant, were looked upon as possessing a supernatural power. For instance, Waller and I were once halting on a journey in a village, and we had with us some of the men who were living under our protection, when we were highly amused by hearing one of them telling the chief of the village of all the wonderful things we had, and of all the wonderful things we could do. Said he at last-

"Do! there is nothing that they cannot do. Look here, chief. Suppose a man wished to get away from them, and they were not willing that he should go, well, do what he would, he could not get away." 
"What would they do to prevent him? Tie him up to a tree?" asked the chief.

"Tie him up to a tree!" was the reply. "No, not they; they would not take that trouble. For suppose he got away, and was so far off that he looked no bigger than a little fly, they would just put a thing up to their eye like this" (meaning a telescope, and imitating the action of raising it to the eye), " and it would bring him back again quite close to their feet."

But we were exposed by this superstitious feeling, which we did our best to correct, to many difficulties. It led the Manganja to think that we had but to show ourselves and the Ajawa would go away, and to look upon us as not friendly if we did not show ourselves to their enemy. We hoped that what had been done would cause the Ajawa to go back to their own country; we did not know at that time that it was impossible for them to do so, and we were greatly concerned to find that they were still in force all round about us. We did not think that they would attack us, but we were told almost daily that they were attacking the Manganja.

First a chief named Katanga begged us to come and drive away a number of these people who had settled in his land and had burnt his village. Then another chief, named Barwi, came and said there was a large encampment of Ajawa close to his village, and that he would soon be destroyed. And so on day by day. Scudamore and others went to see if there was any truth in these statements, and they reported on their return that the Ajawa were certainly where they had been said to be, but that they saw no signs of war, and no proof could be given of any recent act of hostility on their part. They had come into the land, and had settled down in the country, with or without the consent of Barwi and others, but they had lived peaceably, and so we declined to interfere with them.

But the persistence of the Manganja was great, and Chinsunzi and a considerable number of other chiefs, great and small, came to back up Barwi's appeal, and in order to induce us to grant their request they brought us a goat and an Ajawa woman as a present. We had heard of the Manganja making 
prisoners of the Ajawa, and before the Bishop allowed Chinsunzi and the rest to speak upon the subject that had brought them to him, he told them that he had some cause to be angry with them, because they had taken people from the Ajawa and kept them against their will, and he would not listen to anything they had to say unless they brought these people forth, and gave them liberty to go where they pleased.

Most of them looked very crestfallen upon hearing this, but one of them, a man named Kankomba, thus appealed to the Bishop :- " Forget all that is wrong, and come and help us once more, and we shall be happy. My village is not in danger now ; Chinsunzi's village is not in danger now ; but the Ajawa are in Barwi's country, and Barwi sent to all the chiefs and said, 'The English helped you ; do you, therefore, join together in asking them to come and help me. My position now is worse than it was before they helped you, for many who fled from Chirumba have come to me. They have angry hearts, and they will destroy me.' So we come to you, and we say, 'Help Barwi against his enemies.' If you say, 'No, I will not; I am angry. I will not listen to what you say ;' then the Ajawa will burn our villages and carry away our wives and children. You are our master. You are our father. You say that you come to do us good; but if you do not help us we shall all be dead. We cannot stand against the Ajawa. They will take first one village and then another, until all the land is dead to us and there is no life anywhere. You cannot do us good then, for we shall all be gone. Do not wait. Do not refuse to listen. Drive away our enemies, and we will settle our differences afterwards."

This was a good specimen of Manganja special pleading; but it failed, for until he felt sure that all the women and children that had been taken from the Ajawa had been set at liberty, the Bishop would not listen to Kankomba.

After this we were left in peace for a week ; then Barwi came again, and declared that since he had last been to see us the Ajawa had burnt eight of his villages. He was followed by Chinsunzi and others, who brought with them fifteen women and children that had been taken from the Ajawa. Chinsunzi 
asserted that he had brought them, and that none were now kept back; but it turned out that they had been brought by a fine-looking old chief named Nampeko, and that Chinsunzi still kept those he had. Whereupon the Bishop was angry, and told Chinsunzi that he was a bad man who loved a lie; that it was wrong in any man to tell a lie, but far worse in a chief, who ought to set a good example to his people. $\mathrm{He}$ reminded them that they had agreed to set all captives free; and until that was done he would talk to them no more-he would not hold up a hand to save the land.

The Manganja in these transactions did not appear to advantage, yet upon the whole we found them to be better than we expected. They were heathens, and had the faults of heathens, but compared with some Christians they were not exceedingly faulty. They were a timid people, and had the vices of timid people, and lying was one of them. A common expression amongst them was "Ku nama iwe" (you are lying). This was not said as though they thought lying wrong, for they did not; and it appeared to them very droll when we said, "The English do not lie." In the end, however, our truthfulness told beneficially upon them; they believed us implicitly, and rarely lied to us.

On September 5 th, Chinsunzi and others came again with a number of women and children, and from inquiries which had been made amongst the Ajawa living with us, and others well informed on the subject, it seemed likely that all the people that had lately been made captive had now been produced. Some of them were Manganja, who had been made prisoners by the Ajawa, and then captured from them by their own people, and who, but for our interference, would have been kept as slaves. These were at once returned to their friends. The Ajawa amongst them were in a miserable condition; some of the women were literally naked, and the Bishop told them that they should stay with us for a few days and then go where they liked.

Chinsunzi had done all that he promised to do, and the others having done the same, the Bishop said he was willing to hear what they had to say. Nampeko, who lived forty miles 
off, had a tale of woe to tell, and from his story and the statements of others, it seemed that the Ajawa must be in great force all along the southern, western, and eastern faces of Zomba, and that they were cruelly aggressive.

The Bishop in dismissing them said, "I wish I could take all that you say as true, but I cannot. You are constantly saying that which is not true, and we hate a lie. I came here not to fight for you, but to teach you to be better men than you are; to teach you God's laws, to teach you to say and to do that which is pleasing to God; for you say and do many things now which He does not like, because you have never been taught His laws. You are very anxious for us to be kind to you, but you do not seem at all anxious to be kind to others; that is wrong, for we should do to others as we would like to be done unto. We will see where the Ajawa are, and what they are doing. If they are doing all the harm you say, I will try and stop them, but you must keep to your promises, or I can have nothing more to do with you. I have no hatred of the Ajawa; I love them as much as I love you ; but I hate their bad deeds."

Nampeko said all that the Bishop had spoken was good. He was glad the English were going to see for themselves, for they would then know that he had spoken the truth. The Bishop wished Nampeko to accompany him, but the chief said the journey was long and he was sore-footed; and this was really the case; but he promised to send his best man to represent him.

Several days intervened before the Bishop could start on his tour of inspection, but on September 9th, he and Scudamore and William, and three of the Makololo who had been left at Chibisa's by Livingstone, and had come up to us for a time, with Chigunda and some other Manganja, left for this purpose.

By this time, be it said, we had learnt many things about the Ajawa, through the people that were living with us, which showed that they were not so much to blame as Livingstone had thought. They had not left their own country willingly, but had been driven away by the Avisa and other Makoa tribes, who had defeated them and carried very many of them away 
as slaves. Instead of being pre-eminently an enslaving tribe, they were pre-eminently a slave-producing tribe, for they are the Waiou or Yao, of whom many thousands were annually carried down to Zanzibar as slaves. When those that fled came into the Manganja country they were poor and hungry. Like all such, they wanted land whereon to live and food for their immediate needs. They settled where they could, and they took food to save themselves from dying. This brought them into conflict with the Manganja, who at first took many of them prisoners and sold them to the Portuguese slave-dealers. Ultimately, however, the Ajawa found that they were able to beat the Manganja, and then the slave-dealers came to them, gave them guns and gunpowder in exchange for men, women, and children, and urged them to fight against the Manganja and take the whole country. Some of the chiefs, we were told, were tired of fighting, but others were never tired of war, and would not let their people plant, so they had to plunder in order to live.

The Bishop and his party returned in the evening of the I 4 th of September. Their journey had not been eventful, but they had discovered that some of Nampeko's villages had been destroyed, and that Barwi's charges against them were not true, for the villages which he said had been burnt were still in existence.

Nevertheless the fear of the Ajawa was wide spread; the gardens were left uncultivated, and the people were deserting the land or suffering from want of food. But except under necessity we resolved not to assume the offensive against the Ajawa again; and we decided that we would endeavour to open up communications with them, and let them know that if they refrained from further aggressions, they might remain where they were ; but if they continued to plunder, and destroy, and enslave, we should drive them out of the land. The difficulty was to get trustworthy messengers to them. We took counsel with the Ajawa men who were living with us, and they praised our plan, but when they were asked to act as messengers, they instinctively put their hands to their throats, and said that they had no wish to die, and if they went their throats would 
certainly be cut. In the end, it was resolved that Scudamore, Dr. Meller (who had come up to us from the Pioneer), and Mobeta, one of the Makololo, should endeavour to get a conference with the Ajawa. Their endeavours, however, failed, and the Ajawa having become more aggressive, the Bishop resolved to go to them himself, and to adopt measures according to circumstances. He had with him Scudamore, Meller, Adams, Gamble, and the steward of the Pioneer, who was staying at the mission for a time. No conference was had with the Ajawa, but no fighting took place, for as soon as the Manganja who accompanied the Bishop called out, "The English are here," the Ajawa retreated without a gun being fired. The camp was filled with plunder ; this the Manganja reclaimed, and then the camp was destroyed.

During the day many women and children were captured by the Manganja, who behaved very well to them, and brought them all to the Bishop. They were in a state of starvation, and said that they could have got away with the main body of the Ajawa if they had liked, but they preferred falling into the hands of the English. They described the Ajawa chief, Nunkajowa, as a selfish brute, and said he used them when he went on a raid to carry home the spoil, of which, however, he would not permit them to partake, so that they had to subsist on wild roots, or what little corn they could get by stealth. The great majority of these people were Manganja, and were returned to their friends. Some of the Ajawa wished to live amongst the Manganja, and were permitted to do so. Neariy fifty of them, however, desired to come to us, and the Bishop could not refuse them, though as chief of the commissariat I had warned him before he went that we had not sufficient means to enable us to increase the number of our family. But when he returned with these hungry people, and saw how disconcerted I was, he said, "Look at them, you old grumbler, and tell me if you could refuse them?"

Refuse them? certainly not. But I could not help calculating how much food it would take to get these people into condition, and wondering where it would come from. For our stores were running short, and unless Livingstone could let us 
have a bale of cloth, we had not enough barter goods to last until the time for our fresh supplies arrived, and food was getting scarce, for the quantity brought to us for sale daily decreased.

This Ajawa difficulty was a very harassing and time-absorbing business. It was our one great cross. Nevertheless we took things as we found them, and determined by God's help to do the best we could with them.

We were not, as it might seem from this consecutive account of them, altogether absorbed by our troubles with the Ajawa. We did not neglect other work, as the next chapter, traversing the same period of time, will show. 


\section{CHAPTER V.}

$\mathrm{A} \mathrm{S}$ soon as we were settled at Magomera the Bishop planned a regular system of work for all. Houses had to be built, ground had to be cleared for cultivation, the language had to be acquired, and the people had to be taught. There was occupation for all, and every man's capacity was tried to the uttermost. We were up at sunrise. At seven we had morning prayers. At eight breakfast. Immediately after this the whole of cur people were assembled, the roll of their names called over, and to all who could work was assigned a day's employment. Some went to the gardens, and others to cut wood, bamboos, and grass for building. The boys were drilled by Scudamore, and then broken up into classes for instruction. For some time I was too busy with bartering to be able to take my class, so the Bishop took it for me, and for an hour or more every day he would sit under a tree with a lot of little ones around him, trying to make them understand the difference between the form and the sound of A, B, C, \&c. Waller acted as surgeon, besides being superintendent generally of all secular work; and his hands were full, for the number of patients suffering from ulcers, generally in the legs, was great. At one we dined. Between two and three we had classes for adults. At three we went to other occupations, getting up the language, visiting the people, or working at our houses. At six, the time for relaxation, we had tea, and evening prayers at eight. After evening prayers we generally made a tour of our little territory to see that all was well, and then we retired to our respective huts. The Holy Com- 
munion was celebrated on every Sunday morning and on all - festivals.

A few incidents will tend to illustrate the circumstances of our life at this period.

On August 28th, while we were at dinner, there suddenly commenced a great uproar behind our hut, and on going out, we found a young man struggling in the hands of four of our men, and a crowd of women appeared from their gestures ready to tear him to pieces. When we had freed the man from personal danger and had restored order, we learnt the cause of this disturbance. Sonanagana, one of the most intelligent and well-behaved women we had, and the mother of the prettiest little child on the station, stood forth as the accuser. This man, she said, was an Ajawa, and had married her husband's sister. Her husband was an Ajawa also, but they all lived with the Manganja. This man had persuaded her husband to sell her and her child to the Portuguese slave-dealers a few days before we released her, and the fellow was then wearing part of the cloth that was paid for her. He did not deny the truth of the accusation, but pleaded that he had only done what others did before we came into the country. This plea we were compelled to admit, but it did not satisfy Sonanagana; her blood was up, and had we left him to be dealt with by her and her female friends, it would have gone very hard with him. We told them, however, that we could not punish him for what he had done before the Manganja had made buying and selling of people a crime, and saw him safe out of the village.

On the morning of September Ist we discovered that during the night a number of the Ajawa women and children had left us. They were free to go when they pleased, and had they told us that they wished to leave us, we should have given them an escort back to their own people; but we were grieved that they should go off by stealth. During the next day, however, one woman returned and begged to be received back, and said others were a short distance off who were wishing to return also, but were afraid that we were angry with them. We sent kind messages to them and they came in. Of the rest nothing could then be learnt ; but a few days afterwards they also came 
back, and we had some difficulty in restraining the jeers of those who had remained with us. On asking these people why they left us in that way, a woman to whom we had shown much kindness said she wished to leave, and had persuaded the rest to accompany her. They went in the night, not because they were afraid of us, but because they were afraid of the Manganja about us. We told them that they might leave when they pleased, and if they went openly they could go safely, for we would protect them on the road. I asked Akwinani, a fine, bright-natured lad, who had accompanied his mother and sisters, if they had had enough to eat while they "had been away; he shook his head dolefully, so we gave them food, and they went back to their old quarters.

On the morning of Sunday, September 8th, we found most of our people shelling peas. I had given them none, and they had stolen them from the gardens of the Manganja close to us. We went round to every hut, collected all the peas, and assembled all the people, and then sent for Chigunda and the owners of the gardens that had been pillaged. The thieves had really nothing to say for themselves; one or two of them pretended that they had permission to gather peas, but the owners of the gardens shook their heads. Some tried to laugh it off as a thing of no consequence, but the majority looked ashamed. The Bishop was inclined to punish them, but Chigunda and his people behaved generously. Said they, "This is the first offence; do not punish now. We are sorry that the gardens have been plundered, but the thing is done ; let the people keep the peas now they have got them, but don't let them take again."

The Bishop thanked them for their generosity, and gave them compensation in cloth for the loss they had sustained. That done, he made it a law there and then that, for the future, any one living under our protection found guilty of thieving should be severely punished or sent right away from us. And as the rightful owners of them declined to receive their peas back again, they were given to our goats, to the great disgust of the thieves.

We did what we could for these people, but we could not 
do much at that time in making them acquainted with the great truths of the Christian religion. As circumstances gave us the opportunity we endeavoured to correct their faults, and in doing this we always told them that their offence was a sin against God as well as against man, a fact of which they were entirely ignorant; for though they had a vague idea of the existence of a Supreme Being, they had no knowledge of sin as an offence against God; indeed, they did not seem to think that God took any notice of what they said or did. We all felt that it would probably be some time before we could do much more than this ; for the Bishop resolved, and I am sure he was right, not to trust to our interpreters in religious matters. We had then no fault to find with our Cape men, yet we soon discovered that their religious knowledge was scanty, their spiritual sensibilities dull; and that of two evils, delay would be the least.

Amongst our children were two little girls, mere babes in age, who were related to none of our people. They were said to be the children of women who had been captured by the Ajawa, and who had been sold without their offspring. At their age they should have derived their nourishment, according to Manganja custom, from their mothers' breasts, but they must have been deprived of that sustenance for a long time. They showed not the slightest pleasure at anything. I tried my hardest to bring a gleam of pleasure into their eyes, but never succeeded. They would watch for me, follow me with their looks, but their looks were always sad. Johnson, who was a kind-hearted fellow, used to nurse these children, and wash them as tenderly as a woman, and "Bless the Lord, we'll make something of these younkers yet," was one day his expression of self-satisfaction as he placed them after their bath side by side in the sunshine to dry. We did make something of them, but not what we expected; for one night the least hopeless, as it seemed, of these two babes rolled itself into the fire and burnt itself frightfully. The woman in charge of them was fast asleep at the time. In the morning when I went to see it, I found it had groped its way to the door, and was holding up its poor disfigured face to the sky. It was quite 
blind, but knew my voice, and clasped my finger with its uninjured hand. We tried hard to keep life in this little one, but failed. She was the second that we baptized. Her companion seemed to be in no immediate danger, but I baptized her also, and she died a few hours afterwards.

The death of these children made a Christian burial ground necessary, and led me to ask the Bishop what course he was going to pursue with regard to the baptism of our other children, of whom there were seventy under the age of twelve. He said that if he could be reasonably sure of remaining in the land and keeping these children, he would baptize them; but, in the uncertain state of the country, he thought it better for the present only to baptize those who were in danger of death.

September the 17 th was an eventful day.

I. Sesaho, the most amiable of all the Makololo, accidentally killed a child. The Makololo would go nowhere without their guns, which they invariably carried loaded, and on full cock. Sesaho was in search of guinea-fowl, the only kind of game in the neighbourhood of Magomera, and whilst resting in a village, he lodged his gun against a tree. Some children playing about him knocked it down ; it went off, and its contents went into the body of one poor child, and killed it. Sesaho was most miserable. He cried like a child. It was more than we could do to soothe his sorrow, as well as that of the child's relations, to convince the latter that the death had been caused by accident, not malice, and to satisfy both that witchcraft had nothing to do with it.

2. A complaint was made that three of our men had met a Manganja man not far from the station, and had robbed him of a handsome brass armlet. The Bishop assembled all our men, satisfied himself as to the guilty parties, and then gave them the choice of leaving us for ever, or submitting to a flogging. Two submitted to the flogging at once, the other went away for two days, but then came back and asked to be whipped, and whipped he was.

3. This circumstance led Chigunda, who was present and admired our justice, to say that our boys had been guilty of 
plundering also. And after inquiry we found that on Sundays they were in the habit of lying in wait for the pecple who, in ignorance of our custom not to buy on that day, happened to bring things for sale, and of claiming as forfeit what they had brought. We punished several boys who were found guilty of this offence, and made arrangements to prevent anything similar taking place again.

Out of fifty-seven boys we found that thirty-five were Ajawa. Their contempt for the Manganja was supreme. The strongernatured race was manifest in all their actions; and by this time I had begun to like the stronger-natured race, notwithstanding their actions.

3. We heard that small-pox had broken out amongst our people, and found it to be true; and also learnt that it was not an unusual disease in that part of the world. It was called Mtondo, and the Ajawa inoculated their children with it, under the idea that it was milder when produced in this way. We had to take precautions to prevent the disease spreading, but six children died of it before it could be stopped.

4. Damanji, the man who wished for two wives, having furnished his hut, had taken to it the woman he had chosen; but the woman he had rejected, not having met with a husband, was inconsolable. When she saw her rival established in her new home, she rushed about like a mad woman, and talked frantically about killing herself. Before we could quiet her she met the wife and rushed at her, and had we not parted them she would have been severely handled, for she was excited, whilst the wife was cool and also much the stronger.

It will be seen from this catalogue of the principal events of a day, that our poor people were very human indeed; and that the work we had at this time to do amongst them was a little different from that which was once thought by many to be the only proper work for the missionary to the heathen to undertake.

October Ist, being the anniversary of the Farewell Service at Canterbury, was regarded by us as the anniversary of the mission itself. We made, therefore, arrangements to keep the day as suitably as we could, and part of the day's proceedings 
was to erect the first post of a church. The site was chosen, the plan made, and Scudamore, who was a capital woodcutter, felled a good-sized tree for the occasion. After the celebration of the Holy Communion, the Bishop erected the post, having previously buried a bottle close to it, containing a sheet of paper on which was written :-

" This first and corner post of the Church of St. Paul was erected by Bishop Mackenzie, and the Revs. H. C. Scudamore and $\mathrm{H}$. Rowley, on the first day of October, in the year of our Lord one thousand eight hundred and sixty-one, being the first anniversary of the departure of the mission from England."

We talked much over this church. The Bishop was delighted, and spoke sanguinely of having a native congregation of our own people by the time it was finished. Our religious services were exciting great attention amongst them. At first they thought that we assembled together morning and evening for the purposes of magic ; but when they really understood that we met for prayer and thanksgiving to God, they appeared to have less fear, and a more exalted idea of us.

Notwithstanding the distraction caused by the Ajawa we worked on steadily during October. My storehouse was finished, the ground for the boys' dormitory was cleared, and wood was being felled for it. Adams completed a night-house for the goats, and began to build a place for our poultry. Johnson finished his kitchen, and the married people were all well housed. Scudamore felled some more timber for the church. The classes were taken regularly by the Bishop, Procter, and Scudamore, when they were not absent from the station, and irregularly by me.

After October 3 oth, the supply of food rapidly diminished. We did not at first think that food was really scarce, but that the people were too busy in their gardens to be able to come to us. The rainy season was near at hand, and everywhere the ground was being prepared for it. But after a while we found that the people had parted with all they could sell until the first harvest was gathered. We had, however, a good store of corn, and hoped for the best. 
For a time also we had no further complaints of the misdoings of the Ajawa. The Manganja appeared to be relieved of a great fear, and went about with a cheerful alacrity, that was pleasant to witness. Peace and confidence seemed to be restored.

On November 8th we moved into the Bishop's palace. It looked like a large shed, but he was as proud of it as though it were a magnificent erection of brick or stone. Hitherto we had spread our beds on the ground, now we indulged in bedsteads. We also sat at a table at meal-time. True, the table was a rickety affair, the one bit of carpentering our carpenter, a useless creature, had completed, but it was a table, and in that was our satisfaction. Wekotani, the boy who waited upon us, no longer pattered about our plates with naked feet. The Bishop was highly elated, and Scudamore was so much Scuda.. more when we first sat down to dinner at this table, that serious consequences to it were looked for. But the table did not give way, and having set our merriment at naught, we had no further care about it. The Bishop proclaimed his palace to be an end to all our discomfort. But alas for his anticipations! It rained heavily during the night, and on waking I found Scudamore placidly sitting up in his bed under an umbrella. The rain had found out the weak places in the thatch, and the Bishop looked comically aghast.

On November $\mathrm{I} 2$ th we were surprised by messengers from Dr. Livingstone, who had returned to the ship after visiting Lake Nyassa. They brought a letter from him, in which he informed the Bishop that he was going down the river immediately, and that in consequence of the difficulties attending the navigation of the Shire above the Ruo, a stream which flowed into the Shire about seventy miles below Chibisa's, he would not be able to bring up our stores beyond Malo, the island which is formed by the confluence of the Ruo with the Shire. He proposed to be there by January Ist, and said that some of our party must be there to meet him and any other members of the mission that might have come out from England. $\mathrm{He}$ also strongly urged on us the necessity for having a small steamer of our own, as it was impossible for him to help us again. 
The Bishop started for the ship with our mail-bag at four o'clock next morning, not knowing from the wording of the Doctor's letter whether he should find the Pioneer at Chibisa's.

About seven o'clock on the morning of the I8th a number of Chibisians came into Magomera with burdens, and one of them brought a letter from the Bishop. It was written at Pingwi, a village half-way between Soche's and Mongazi's, and said to our astonishment and joy :-

"Three men from England to join our mission have come up from Quilimane. One Burrup, a clergyman, is with me now. The other two, a doctor and a shoemaker, are coming. The letters were in time. The Pioneer started on Friday at ıо A.M. We shall rest here to-day, Sunday, and hope to be home tomorrow night, but we are both knocked up. I got down on Thursday, at IO A. M." (By this he did the seventy miles in thirty hours.) "Burrup has been helping to paddle his own canoe, and has had bad nights. There are letters of date about June in the hands of the doctor. God the Holy Spirit be with you this day. I should like to be among you."

The Bishop and the Rev. Henry De Wint Burrup arrived on the I 9 th, both looking very weary. The journey of Burrup and his companions up the river was a remarkable feat, and must have tried nerve and endurance to the utmost. Burrup had left Dickinson and Clark, who were in a larger canoe, nine days before his arrival at Chibisa's, and intended to have returned to them as soon as he had found the Pioneer, but as the ship was going down the river immediately, there was no need for him to do that. Charles, who went down with the Bishop, was left at Chibisa's in order to guide Dickinson and Clark to Magomera.

Our new coadjutors left England on April 6th, and after staying a few days at the Cape, were taken on to Johanna in a man-of-war. There they learnt that we had returned to the Zambesi, and resolved to follow us. H.M.S. Gorgon agreeing to take them to Mozambique, they preferred to find their way from that place to us, wherever we might be. Before leaving Johanna our stores were removed from the Government store-ship. Nine-tenths of them were spoiled, and were thrown 
into the sea, the remainder was sold to the various ships then at Pomoney.

At Mozambique our friends were received most cordially, and were forwarded in a coasting vessel to Quilimane, from whence, with the aid of Portuguese canoes, they were able to get up to us.

Hard things have been said, and rightly said by myself and others, of the conduct of the Portuguese in Africa towards the natives, but their kindness to us whenever we needed their aid was great. No men could have acted more generously.

Both the Bishop and Burrup were far from well for several days after their arrival. Indeed, the Bishop never really recovered his former elasticity of spirit. I think he was much troubled by the position in which we were placed by Dr. Livingstone's inability to give us further aid. The Portuguese had helped Burrup and Dickinson, but it did not then occur to us that they would be able and willing to help the mission regularly. Livingstone said that a steam-launch was necessary to our existence, but though such a vessel might help us to get up and down the river, it would not supply all our needs, for a regular communication with Capetown was as necessary to us as a regular communication with the coast, and we could not suppose that Her Majesty's ships would be always permitted to aid us. The Bishop's great care, however, was an immediate one, for if he wrote home for a steam-launch it would be three years before we could get her, and he was troubled to know what could be done in the meantime, and what arrangements could then be made for getting up our stores from Malo; and under this trouble he for several days seemed to lose a great deal of that bright hopefulness which was so remarkable a feature of his character.

Dickinson and Clark arrived at Magomera on the morning of November 29 th, and they brought our letters with them, the first some of us had received since leaving England. We first of all had a thanksgiving service for their safe arrival, and then the day was given up to news from home.

By this time the people had ceased to bring food for sale, so we went out daily to buy what could be had in the villages. 
It was a great satisfaction to find that for miles around Magomera the cry of "Kondo!" (war) had ceased, and that the Manganja were hard at work in their gardens, and cultivating more ground than they had ever done before, in the hope of procuring cloth by their surplus crops.

We did all we could to prepare for the inconveniences of the rainy season, which we feared would prove a hard time to us, for though Magomera had not then proved absolutely unhealthy, Dickinson soon condemned it as the most unhealthy place in the whole country.

We did also what we could to prepare for the reception of the Bishop's sisters and Mrs. Burrup, who, with others, were expected to arrive at the Zambesi with our second year's supplies. Clark began a large house for them, and under the direction of Dickinson something was done to improve the sanitary condition of the station.

It was necessary to send some one overland to the Ruo to make friends with the various chiefs along the road, and arrangements for the carriage of the stores which Livingstone had promised to bring up so far; and the Bishop decided that Procter and Scudamore, accompanied by Charles, should undertake this work. They left us, therefore, on the morning of December and.

Five days afterwards Charles returned to Magomera alone, the very picture of a man who had been hunted for his life.

"All are gone! I alone am left! Not one besides myself has escaped!" said he. And then he sank down to the ground and burst into tears. He then told us that at first all went well with the party; there was a good road and friendly people. But when they came to a village belonging to a chief named Manasomba, the inhabitants attacked them.

"Twice," said he, "was I surrounded. I hardly know how I broke away. When I was about a hundred yards off I heard two shots fired. I fear this was all Mr. Procter and Mr. Scudamore could do before they were overpowered. The natives were all around them firing at them with their bows and arrows."

This horrible news soon spread, and the natives crowded 
about the station, as sorrowful as we were. We had to consider what was the best thing to be done; and the Bishop had just come to the conclusion that we should go down with all the force we could muster to Manasomba, and rescue our brethren if they were alive, when Winapi, one of our women, rushed up to my hut where I, ill with dysentery, was talking with Johnson, and clapping her hands exclaimed, "Johnson! Johnson! Anglesi! Anglesi!"

Johnson ran out, and I followed, for the effect of this woman's words was electrical; and there, sure enough, were our dear brothers coming towards us, unhurt, though worn and wearied. We received them as those who had been given back to us from the dead.

Our people were as delighted as we. They came forward to welcome our friends with a heartiness of feeling that we had not looked for. They felt with us in our sorrow, and sympathised with us in our joy.

From the narrative of our brethren it seemed that until they got to Manasomba's, which was on the Ruo, but probably fifty miles from the Shire, they passed through a country everywhere well cultivated, and on which the rain had wrought wonders, as the ground was clothed with the richest verdure, and adorned with flowers of every hue. One chief after another gave them welcome, and when they were told that the object of the journey was to open a path from the mouth of the Ruo to Magomera for the carriage of our goods, they said that would be a good thing, as the people could then earn cloth as carriers. At Manasomba's, however, the conduct of the people was so insolent and suspicious, that it was thought advisable not to rest there for the night. But when they attempted to leave, the men of the place followed them, and assumed such a hostile position that our brothers, thinking that they had infringed some piece of African etiquette, sat down under a tree and invited the men to come and talk the matter over. This was done, and then it seemed that the chief was waiting to receive them; so they returned. Manasomba was an old man, once a very powerful man physically. He pretended great friendship, produced food, and would not hear of our brethren leaving 
him until the morning. But the people clustered about in a very suspicious manner, and seemed as though they were bent on mischief. Nothing could be done, however, but watch and wait. But when it was nearly sundown, Charles appeared in a state of great excitement, and said that a woman had told one of the bearers that Manasomba and his people intended to attack the English as soon as it was dark, and kill them. In confirmation of this, the women were seen to be busy in removing their household utensils, and hurrying out of the village, as they always do when a fight is expected. The men were sitting round the huts with their bows and arrows beside them. For fear of exciting attention the bearers were collected quietly, and while the burdens were being packed, Scudamore went to Manasomba to keep him in conversation. But he was not to be hoodwinked, for Scudamore heard him whisper to a man to tell all to be on the look-out, as the English were preparing to leave. Scudamore then assumed a bold bearing, and told him that they would not stay any longer with him; upon which the old rogue gave a great shout, and all his people were at once on the alert, and ready to prevent our friends leaving-when they attempted to do so.

It was nearly sunset; and as Scudamore and Procter went towards the exit from the village, Manasomba's men crowded before them, but gave way whenever they brought the muzzles of their guns to bear upon them. At this juncture a man called out, "Stop the gate!" Here Charles did good service, for before this could be done, he made a dash at the men at the gate, and knocked away the obstacles they were placing there. Scudamore and Procter then hurried on the bearers, and followed them. But as soon as the bearers were outside the gate they were immediately attacked, their burdens knocked off their heads, and most of them made prisoners.

Fortunately the plunder drew off the attention of many of the assailants, and this enabled Procter and Scudamore to get quite clear of the village, though a number of men rar. round about them shouting "War!" At last three men sprang upon Procter, and endeavoured to wrest his gun from him, and in the struggle he fell, still holding his gun, which he managed to 
discharge. No one was hit, but all were frightened; and when Scudamore, who was slightly in advance, also discharged his gun, Procter's assailants left him, and fled. Arrows were discharged at them from a distance, one of which struck and stuck fast in the stock of Procter's gun. Had he not been holding his gun in a most unusual position he certainly would have been wounded in the thigh.

Procter and Scudamore then struck off into the bush, and when darkness set in, they stopped, deliberated, and prayed for guidance. Feeling that they could not trust the people of the country after what had happened, they resolved to avoid the villages. They had lost everything, and had a march of eighty miles before them. They suffered much from hunger and the hardships of the way; and when they arrived near to the station a doleful reception awaited them, for the wives and the children of the bearers who had been made prisoners were wailing for them as though they were dead.

It was necessary that the men who had trusted themselves to our protection should be released, and that Manasomba should be punished for his treachery. So the Bishop arranged to take a strong party with him as far as Manasomba's, and then go on to the mouth of the Ruo where he expected to find not only our stores, but his sisters, Mrs. Burrup, and others.

It was not till December 23 rd that the necessary preparations were completed. The party consisted of the Bishop, Burrup, Scudamore, and Waller, with William, some of Chigunda's men, and ten of the Makololo, who came up to us as soon as they heard that we were in need of help. I could not go with them, for I was too.weak from the effects of dysentery to walk a mile.

At this time our people were suffering much from want of food. For some weeks there had been a difficulty in getting provisions for them. Owing to the unsettled state of the country a great deal of land had been left unsown in the previous season, and the pumpkins and corn which had been lately planted could not be gathered until the end of January. Instead of the natives flocking in e rery day with food for sale, 
they sometimes came to ask for a little food from us, and it was no uncommon occurrence in many parts of the surrounding country to find by the wayside the bodies of natives that had died of hunger. Our reserve stock of food was exhausted, and we sent far and wide into the country to buy anything that the people could eat; but with all our efforts we could give them but one meal a day, and that a small one. Disease accompanied this insufficient supply of food, and a stomach sickness, which Dickinson could not arrest, carried off a considerable number of our children. There was one little one that the Bishop tried to save. It was but a babe, whose mother was too weak to sustain it. Finding that the mother could not feed it, and that there was no other woman ready to do so, he rigged up a bottle in such a way that the little one could suck milk from it. I came upon him just as he was making his first attempt to feed this child. It was a pleasant sight to see him with the dusky, naked little creature, carefully holding it with one arm, while with the disengaged hand he held the bottle to the tiny lips, anxiously watching the result of his experiment, and brightening with satisfaction when he found it succeed. The youngster sucked away right heartily, and when he was satisfied he looked about a little, gaped a little, played a little with the Bishop's big beard, and finally thrust its little wizened face against the Bishop's chest, and went to sleep. Before the Bishop started for the Ruo he gave this babe to a woman to nurse, but under her care the child seemed to suffer; so I then superintended its feeding. The little fellow sucked hard for life, but it was all of no use, he gradually withered and died.

On the 24th I distributed all the corn we had, it was not half a ration for each; and on Christmas Day I laid hands upon the remainder of our biscuits, for it was impossible to see the children die of hunger while there was any food left. How the following week was got through I scarcely know ; but on New Year's Day (I862) I was able to dispense a bountiful meal to all, for Charles, who had been out foraging, came in with a considerable supply of corn, and some men from Lake Shirwa brought a large quantity of dried fish for 
sale. Hitherto we had been unable to get these fish-sellers to come to us. It was said that they came into the country only in times of scarcity, and then in order to get women and children in exchange for their fish; but as our presence made such exchanges then impossible, they were glad to have our cloth, and we bought their entire stock.

January 2nd was an eventful day. About eleven o'clock two of the Makololo, Moloko and Maseka, who did not accompany the Bishop to the Ruo, came to us and said, "When we left you a few days ago we went towards the Shire, not by the way that you go, but by another way which took us to the waterfalls. When we were near the river we entered a village in which were Portuguese slave-dealers. As soon as we showed ourselves there was a cry, "The English are here!" and the slave-dealers ran away, leaving all they had behind. We took the men, the women, the children, the cloth, the beads, and the brass, and have brought all to you. Do what you like with them all."

They then fetched "all" to us. These were five men in slave forks, six women, and ten boys; and a considerable quantity of barter goods. We freed the men from their cruel yoke, and told them all that they might return to their friends at once, or go where they pleased. They were Ajawa, and had been sold by their own people. They found many acquaintances amongst our protégés, and said that they did not wish to return to their camp, as they might be sold again, and did not care to trust themselves to the Manganja, who were their enemies, but would be very glad if we would let them live with us, for all the Ajawa now knew that the English were friends, and that they had good hearts.

We gave the men and women permission to live under our protection, though we could not undertake the responsibility of finding food for them, but the children we adopted, for we looked upon them as intrusted to us by God; and believed that $\mathrm{He}$ would enable us to feed them.

We did not wish to take any of the spoil for ourselves, but when the Makololo heard that we were short of barter goods, Moloko said, "Take the cloth to buy food for the people we have. brought you." And we borrowed fifty fathoms for their support. 
About two o'clock in the afternoon of the same day, the Bishop and party returned. They were all suffering more or less from the effects of their journey. Scudamore seemed to be almost at the point of death. When he came in he fell down on my bed, utterly exhausted with fever and fatigue. They had been exposed to an almost incessant rain. Every streamlet on the journey had become a torrent, and almost every path a streamlet. They had been scarcely an hour out of wet clothes since they left us.

On Christmas Day they arrived at a village belonging to a chief named Saopa, where the people were starving, and where the loud wailing for the dead told its own sad tale. Here, however, they decided to halt, and here under the precipices of the Milanji mountains, amidst scenery as grand as any in the world, and yet within sight and sound of the most hopeless forms of human misery, they celebrated the Holy Communion.

On December 26 th they resumed their journey, Saopa going with them as guide. They went in a pouring rain, through a country that had become almost a bog, until about 6 P.M., when they came to a river which ran furiously, and which they had much trouble and danger in crossing.

On the 27 th they arrived at Manga, the village of Chipoka, who had entertained Procter and Scudamore, but whose conduct afterwards made them think that he was in some measure an accomplice of Manasomba. $\mathrm{He}$ it was who had sent them on to this chief, and though he admitted that Manasomba was known to him as a bad man who lived by plunder. ing others, he defended himself by saying that he had never injured any of his friends, and to show that he was sincere he was ready to accompany the Bishop against him. It was thought prudent to give him credit for good intentions, though his explanations were not altogether satisfactory. From further information derived from Chipoka, it appeared that Manasomba, expecting the English to come upon him, had, a few days after Procter and Scudamore escaped from him, collected all his men, and encamped on the banks of the Rikania, a river that flows near to his village, intending to defend himself there But the rain brought sickness upon his people, and they were 
obliged to disperse. Then he tried to get the neighbouring chiefs to make common cause with him, but this they refused to do, and he was then living in a state of fearful apprehension.

On December 28 th the Bishop and his party were up at dawn and went on towards Manasomba's. On their way they saw the deserted camp by the Rikania, and when they came near to their destination they halted, and prayed that God would aid them, and enable them to establish justice and judgment as His will amongst the heathen. Shortly after this they saw a large body of men advancing towards them. On seeing the English they halted, and after an ineffectual attempt at a parley, they retreated.

The Bishop and his party now advanced, and unopposed they entered the village, which was deserted. In a hut belonging to the chief they found Procter's valise, and other things belonging to him and Scudamore. The Bishop ordered everything in the place to be collected, including a large number of slave forks, and then destroyed it by fire. This was a fitting punishment for Manasomba's offence. No life had been taken, but the destruction of his village was a sign of defeat, a degradation that would cling to him through life. The people round about, who knew of his offence, would hear also of his punishment, and that he was powerless to prevent it, and evil-doers would fear.

The possibility of the Ruo route to the Shire was anxiously debated at Manga, where the party rested a day or two. Scudamore was much too ill to proceed, the Makololo refused to go any farther, the exact distance was unknown, the chiefs would not provide guides, and the provisions were nearly exhausted. It was a great trial to the Bishop and Burrup to turn their backs upon the route which they believed would have brought them in the course of a day or two to Malo, and to recommence their weary march back to Magomera, only to start immediately on another journey of nearly two hundred miles. But there seemed to be no alternative, and accordingly the march homewards was "esumed, and Magomera was reached on January 2 nd.

After one night's rest, the Bishop and Burrup started again 
soon after midday, the Makololo carrying their baggage. It rained heavily before they went, and recommenced soon after they left. The Bishop was very sad when he departed, the condition of Scudamore, for whom he had much love, greatly tried him. Before he went he assembled the whole mission party and gave them his blessing.

For several days Scudamore appeared to be fluctuating between life and death, but on the 8th he rallied a little, and afterwards recovered strength daily.

Amongst our people, however, sickness was on the increase, and my journal at this time is simply an obituary. Dickinson was unremitting in his attentions to the sick, and did everything that could be done to better their condition, but a sickly season, a pestilential locality, and semi-starvation proved too much for him. One after another the young and the weakly died ; for though the pumpkin crop was reaped earlier than we expected and saved many from death by starvation, the effects of previous privations were fatal. Our little band of hope was gradually wasting away, and, under God, it was owing to Dickinson that we missionaries did not die also, for any thing more truly wretched than our condition for several weeks after the Bishop left us cannot well be imagined. Yet our life was not without its consolations.

On the 27 th, for instance, we were surprised, when we turned out in the morning, to find a number of strange men, unarmed, sitting in front of the Bishop's palace, desiring to speak with us. They were Ajawa, and they had come into Magomera during the night for fear of the Manganja; but they did not fear to put their lives into our hands. Said they :-

"Our chiefs have sent us to ask you to let them and their people come and live near you. We know that you are not enemies, for we see that Ajawa live with you as friends. They tell us that when the slave-dealers were taking them out of the country you freed them, when they are hungry you feed them, when they are sick you give them medicine, and when they die you bury them. An enemy never does that. We wish to live at peace with the Manganja. We are tired of war, and want to sow and to reap. But the Manganja will not let us live at 
peace; they will not let us make gardens, they will have war ; so we should like to come and live near you, then we should have peace, for all would know that you were our friends."

We had no power to grant the request of these men, for Chigunda would not consent to their coming to live near him; had he done so his brother chiefs would have regarded him as a traitor ; but we assured them of our goodwill towards them, and told them that when our chief (the Bishop) returned, we would do all we could to make them and the Manganja friends.

The woman who acted as guide had been at the station before, and she begged hard that she and her husband, a fine, stalwart, honest-looking fellow, named Chimlolo, and their child, might be permitted to stay with us, on the ground that the Bishop had promised that if she came back with her husband she might remain. We granted her request, and never regretted it, for Chimlolo proved to be a trustworthy and excellent man. She was a handsome woman, despite the lip-ring, and modest and well-behaved at all times.

The others went away at night, being afraid to pass through Manganja country during the day. The implicit trust that these men had in us was very gratifying. We hoped that their interview with us would lead to happy issues, would enable us to get a position amongst the great bodies of the Ajawa. No event, since our arrival in the country, gave us so much satisfaction, it was a cause of real thanksgiving. It was a proof that our proceedings against the Ajawa had not made them irreconcilably our enemies. It would have been strange if it had been so, for against them we had no animosity.

Another event served to show that our labour amongst the Manganja was not in vain. Ndoka, a man whom we released from the slave-dealers, married a woman some years his senior, whom we also released. She was a widow when he married her. Her first husband was killed, and when she was sold, she was parted from her child, a girl about two years old. Accidentally she discovered that a man named Kankadi who lived not far from the station had got her child. She begged him 
to let her have it, but he would not. Then Ndoka complained to us. We knew Kankadi. He was a big-boned, knotty. browed, rugged-looking fellow, and was said to be given to deeds of violence. We sent for him, and bade him bring the child with him. He came, and we told him that our object in sending for him was to bid him give the child back to its mother, whereupon he assumed an insolent attitude, and said-

"The child is mine. I saw a man who wished to sell her for food. I have no wife. I have no child. I want a girl to grow up in my hut to grind my corn, and to fetch my water; so I gave the man three baskets of corn for the child. If the English want her, they must buy her as I bought her; but I don't want to sell the child."

Kankadi was one of those who were present when the buying and selling of human beings was made a crime. This Chigunda admitted, and said that he had done wrong; but though he was his chief he was evidently afraid of him, and declined to take the child from him.

We told Kankadi that the child was not his, that he must give it up to its mother, and pay a fine for having broken the covenant he had made with us. Upon which his face assumed an expression which was not pleasant to behold, and he replied in hot anger-

"It is a lie! I never promised not to buy slaves; all I promised was not to sell to the Chakundas. I have not done that, and I have done no wrong. I bought the child for myself with my own corn. I will not give her up. The English are strong; let them take her. But"

What the "but" exactly meant he did not say, but it meant mischief, for he twanged his bowstring fiercely.

We were strong, and could have taken the child from him, and driven him from our presence, but before doing that, Waller tried to influence him for good in another way. $\mathrm{He}$ told him of the sorrow of the poor mother when she lost her child, and who was then trembling with anxiety to have it returned to her. . He told him of the sorrow that was troubling the hearts of many poor mothers in that land, whose children 
had been taken away from them and sold. And while he thus spoke a better kind of feeling came over the man. His face assumed a milder expression. And when Waller said-

"Suppose you had a child, and it was stolen from you and sold; would you not think those who did that very wicked? Would you not feel as sorry as this poor mother here?"

An expression as of pain passed over his face, and after a few moments he said in a subdued voice-

"It is true. I should feel it here," laying his hand over his heart. "My heart tells me that it is wrong to take the child from the mother. I will keep this child no longer. I want nothing for her. I give her back for nothing."

And the child was returned to its mother.

With the month of February the new corn came in. Sickness and death were still prevalent, but hunger ceased. In their joy of heart those that were in health began to dance during the moonlight nights, and the noise of the dancers, after the long period of silent sadness broken only by the cry of jala (hunger) and the wail of death, was as music to our ears.

These moonlight dances were simply for amusement, and were in no degree objectionable; it is only those dances that are connected with the superstitions of the natives that have an evil tendency. 


\section{CHAPTER VI.}

THE protracted absence of the Bishop and Burrup was the 1 cause of much anxiety at Magomera. It was known that their supplies, unless they had met with Dr. Livingstone, could not last more than a month or five weeks, and that a long sojourn at Malo would be dangerous, as it was in one of the most pestiferous parts of the Shire valley. At Magomera the store of barter goods was almost exhausted, and there was scarcely any food but green corn and pumpkins. But it was felt to be impossible to remain much longer without making an effort to gain information of our absent brethren, and it was resolved that, in the event of their not returning within a week, some of the mission party should go down the river to them. But before the week had passed all was known.

On February I 4th, Zomba, one of the Makololo, came to the station. His manner was constrained, and he looked like the bearer of evil tidings. When we asked after the Bishop, he hid his face in his hands. It needed no words to tell us what had happened, but after a brief silence he said, "Wafa!" (He is dead.)

He then told us that Burrup was alive, but very ill, and, carried on men's shoulders, was near at hand. When he was brought in, it was seen by all how much he had suffered. He did not seem to realise how ill he was, for he was one of those men who feel nothing but the blow that prostrates them. $\mathrm{He}$ was not able to give any connected account of what had taken place since he and the Bishop left, but from his statements made at various times, and the Bishop's journal and letters, sufficient information was obtained. 
Their journey to Chibisa's was delayed by the incessant rain, in consequence of which the streams on the road were greatly swollen, and not easily forded. Two days after they left, the Bishop, when writing to his sister, says-

"We are sitting still to-day. We have had morning and evening prayer and litany; no communion, as we are only two Christians, Burrup and myself. Yesterday we trudged through heavy rain with rather unwilling followers, and at one stream, which I suppose we commonly step across, we were obliged to wait till the stream went down. I think we could have got across ourselves, but the burdens were the difficulty. While we waited some two or three hours in a low hut, with a fire in the middle, I was for some time absorbed in a reverie, imagining our meeting-now, I trust, within a week. God grant it may be a happy meeting, and be the beginning of such time as He may give us to work for Him ; and there is plenty of work for you all. I have with me, besides Bible and Prayer-Book. my copy of Keble, and my little Greek Testament. We read this morning the hymn for the day and the morning hymn, and we have taken the plan of learning, each day, a verse or two of the Greek Testament-some important passage-and talking it over together. These were Burrup's suggestions, and I think they are good. We are neither of us quite well, our tempers are a little tried, and this makes a bond."

It was not until January 8th, that they arrived at Chibisa's, where they borrowed a canse, and secured the aid of three of the Makololo as canoe-men. Their progress down the river was rapid. On the first night they slept at Chikwaba, where they were cordially received by the chief and his people. Next evening, they halted as the sun was going down at a village in the Elephant Marsh belonging to a man named Magala. Here, however, the flies and mosquitoes were so troublesome, that Burrup urged the Bishop to seek another resting-place, and he consented. This was a fatal movement; for darkness came on before they could reach the place they sought, and missing the main stream they turned into a creek, where the canoe touched a bank and was upset. The water was not more than four feet deep, but the accident was productive of serious consequences. 
Guns were made useless by the loss of ammunition; the tea and coffee were so damaged as to be worthless; and, worst of all, the medicines which had been carefully selected and plentifully supplied by Dickinson, were utterly destroyed. Burrup lost his valise containing clothing, and the Makololo lost their little all. They were for an hour in the water endeavouring to recover their things, and putting the canoe to rights. Then they wrapped their wet rugs around them and slept in the canoe.

Return for fresh supplies they could not, for it was then the roth, and Livingstone had made it imperative that he should be met at Malo on the ist. So next day they went down to Malo, and learnt from the natives there that the Pioneer had passed by a few days before, having been detained, as we learnt afterwards, nearly seven weeks between Chibisa's and the Ruo by sandbanks. Had Livingstone left a letter for the Bishop at Malo, he would have known that the ship had passed only five days before his arrival there, and rather than make a long and uncertain sojourn at this most unhealthy place, he would probably have followed him down to the Kongone, or have returned to Magomera. But in consequence of the indistinctness with which Africans compute time, the Bishop could not tell how long the few days really meant, and so he resolved to wait at Malo for Livingstone's arrival, hoping that during his stay there he might do something towards facilitating a plan which he contemplated for periodical visits being made to all the villages on the banks of the river.

Malo is about three-quarters of a mile in length, and a quarter of a mile in breadth, and it then contained about 500 inhabitants. Chikanza, the chief, was friendly, and placed one of his own huts at the Bishop's disposal. Fowls, eggs, meal, and beans were to be had in abundance, so no inconvenience was felt from want of food. But writing a few days after their arrival the Bishop says: "Burrup has not been quite well since the upsetting of the canoe. I am myself, thank God, in almost perfect health, and only regret on my own account the loss of the little packet of drugs, inasmuch as I shall probably have a touch of fever soon for want of quinine." This anticipa- 
tion was too sadly realised. From this time his strength seemed to fail. He took no exercise, would sit in the hut all day, and was occasionally much distressed by the difficulties in which he was placed. He several times spoke as though the want of means to keep up a regular communication with Capetown would prove fatal to the mission. There seemed to him no possibility of getting the ladies and the stores from Malo when they arrived, unless Dr. Livingstone could help him, and of that he had but little hope. Nevertheless, he longed for the arrival of his sisters, and once said to Burrup he thought his heart would break if they did not now come. $\mathrm{He}$ used to rejoice in the thought of the pleasure they would experience when they saw how many children God had committed to the mission to be trained in His fear and love; but in wishing for them at Malo he was evidently hoping against hope that all would be well, and that they would get up to Magomera without great discomfort. $\mathrm{He}$ was one of the most hopeful of men. This feature of his character often led him to overlook many things in which a less hopeful man would have discerned the germ of much future discomfort; but it was very pleasant to be associated with him, for if his hopefulness brought upon you a little inconvenience now and then, it carried you safely over many difficulties that a more cautious man would have stumbled at. But had he been less hopeful, his position at Malo could not have been avoided. It was due to his dependence upon Livingstone, and to Livingstone's inability to do for the mission what he had promised. That we were kept in ignorance of the aid which the Portuguese could give us was a grave mistake. Had we entered into relations with them from the first, the history of the mission would probably have been very different.

A short time before his strength failed, and when he was more anxious for his friend than for himself, the Bishop wrote : "I read to Burrup this morning the Keble for the twenty-fifth Sunday after Trinity. I do so admire the verses." The last words of this letter were, "Burrup is very low; we have no medicine; of quinine, which we ought to be taking every day, there is none; but $\mathrm{He}$ who brought us here can take care 
of us without human means. If we should both be down at once, Charlie (the Makololo) will take care of us. The texts in Greek which we have learned, day by day, have been Romans xi. 28,29 , iii. 2 I, vi. $\mathrm{I} 3$, vii. 24,25 , viii. 38,39 : I am persuaded that ' neither death nor life, nor angels, nor principalities, nor powers, nor things present, nor things to come, nor height, nor depth, nor any other creature, shall be able to separate us from the love of God which is in Christ Jesus.' Good-bye for the present."

Such were his last written words, for soon after the final break-down began. On the 24 th he was incapable of collected conversation. His mind wandered, yet he spoke of the mission repeatedly. At one time his difficulties appeared to overwhelm him, at another he had seemingly surmounted them, and he and his sisters were at Magomera, to him a haven of safety. But on the $25^{\text {th }}$ he became quite insensible, and from that day to the 3 Ist (January 1862), the day of his death, he was unable to utter a word.

The natives have a superstitious dread of any one, especially of a stranger, dying in their huts, and setting aside the superstition, the doing so is a great inconvenience to them, as the hut after a death is closed for three years; so when Chikanza knew that the Bishop was dying, he begged that he might be removed to another hut, to one less needful to Chikanza himself. This was done, and he died at five o'clock in the afternoon of the same day.

As soon as his death was known, Chikanza was anxious for the immediate interment of the body. This was, without doubt, from superstitious fear, not from unkindness. The Makololo also wished it, and certainly from no lack of affection. So Burrup consented, and he and they went over the river to the north bank of the Shire, and clearing away the bush from a secluded place, dug a grave. It was dark before the body could be laid in the ground, too dark for Burrup to read the Burial Service, and so he said all that he could remember of it.

A wasted life! say some. A wasted life? No! a thousand times, no! Like Abel, "he being dead yet speaketh." Bishop 
Mackenzie is to this generation what Henry Martin was to a past. Both were men of exalted character and great ability; and both achieved highest distinction at their university. Henry Martin resolved to "hazard his life for the name of the Lord Jesus" in India, and of him it has been said with a sneer, "he never made a convert!" That may or may not be true, but though he may have made no converts himself, his example led forth others to carry on the work which he began, and through their instrumentality thousands have been won to Christ in India. Now what Martin is to India, Mackenzie is to Central Africa, and by and by it will be surely seen that by his death he, like Samson of old, accomplished far more than by his life,-far more, it may be, than if his life had been prolonged to threescore years and ten.

After the Bishop's death Burrup resolved, without further delay, to return to Magomera. The river was full of water, the current very strong, and the Makololo were anxious to return by land. But this he was not willing to do, as he was under an engagement to restore the canoe to its owners; so on February $2 \mathrm{~d}$ they began the ascent of the river. For three days they laboured, but made such little progress that the Makololo declared it was useless trying any longer, and the canoe was left in the care of some natives, and the journey continued along the bank of the river. Burrup was so ill that he fell down repeatedly during the three days they were in getting to Chibisa's. Nothing but his indomitable will kept him going. But at Chibisa's his break-down was complete. During the two days that he stayed there the Makololo were most attentive to him ; indeed he met with nothing but kindness all along the road. Mankokwe, the Rundo, through whose village he passed, himself conducted him to the next halting-place. Finding that he could walk no farther, the Makololo and the Chibisians made a palanquin of wood and bamboo, and carried him up to Magomera. This was done without promise of reward, and without hope of reward. As he was leaving Chibisa's, Moloko, finding that he was without cloth, held out some and said with much true feeling- "Here, Burrup, take this cloth to buy food on the road home." 
Burrup said but little of his own sufferings; but he was only not dead when he arrived at Magomera.

After evening prayer on the $\mathrm{I} 4 \mathrm{th}$, Procter informed us that before the Bishop went away he intrusted a paper to him, which he desired him to read to the members of the mission in the event of his death. It was his will. That part of the will which related to the mission expressed the wish that the members should "act under the temporary headship of the senior priest acting with the advice of the other priests; or if there be no priests, the senior deacon; or if there be no deacon, the senior layman, acting with the advice of their own degree respectively." Procter therefore became, pro tem., the chief. It was a trying position for him, but all did their best to strengthen his hands, and to maintain "the unity of the spirit in the bond of peace."

The first thing that claimed the attention of the missionaries was the condition of the people who were living under their protection. It was never intended that they should remain dependent on the mission. At first they had not the means of supporting themselves, and they were fed by the mission, and gave work in return; but at this time most of them had gardens, and the first crops were ready to be gathered. They were told, consequently, that the time had arrived when all but the sick and the children must feed themselves, and that for their work they would receive payment in cloth or its equivalent. None were cast down at this announcement, none wished to leave. Damanji and Lonkola, two of the best behaved of our men, made speeches in which, in behalf of themselves and all the rest, they professed eternal friendship for the English, declaring somewhat in the language of Ruth that where we went they would go, and that our people should be their people. More than that they could not say, but there seemed to be good reason for hoping that very soon some of them at least would be able to add, "and your God shall be our God." They declared that they owed all they had to the English, that when they were dead the English had given them life (by which they meant that when they were captives the English had given them liberty), and that they desired nothing better than to live and 
die with those who had been such good friends to them. Of the Bishop they said that, when he died, there went from them the chief with the sweetest heart on earth.

At that time the condition of the country was most hopeful. The crops were yielding more than a hundred-fold. The English wheat, it is true, did not look well-in ignorance of the seasons it was sown too early-but the barley and the oats flourished.

Everything was done to improve the sanitary condition of the Mission Station. The sick were removed to separate huts outside the village. The dormitory was fitted up and kept exclusively for the healthy children. Each child had a bamboo bedstead, instead of lying on the ground, and Clark, whose usefulness was great and varied, fitted up a berth for himself, and had the general superintendence. But day after day passed and there was no improvement in Burrup's health. He was evidently a dying man, yet he was unconscious of his condition. Only once did he say anything that tended to show that he knew how ill he was, and that was the day before he died. Finding himself for the moment unable to rise from his chair in order to get something that he wanted, he said"If I don't soon get rid of this diarrhœa, I think it will go hard with me." But shortly afterwards he expressed his conviction that he would come safely through it all. He might have recovered, if from the first we could have given him wine, and brandy, and nourishing food. But he never complained: he had the fortitude of a hero and the faith of a martyr.

On the morning of February 2 2nd, he was up by six o'clock, walked across the village to the kitchen, returned, drank two cups of coffee, and almost immediately fell back in his bed insensible. He never recovered consciousness, and died at a quarter to II A.M.

Next day, Sunday, after the celebration of the Holy Communion, we buried him at the bottom of the village, within the enclosure marked out for the church. Our sorrow was intensified by the thought that his young widow, with the Bishop's sisters, might be close at hand.

The probable arrival of these ladies caused us much anxiety. 
Even under happier circumstances their coming to us at so early a period in the history of the mission would have involved both them and us in trouble. Only men capable of doing much and enduring much are equal to the trials and hardships incidental to the pioneer work of such a mission as ours was. Of course we had to discover all this for ourselves. Bishop Mackenzie did not write for his sisters until Dr. Livingstone told him that he might safely do so.

The expectation of the early arrival of the ladies was fulfilled. On the morning of March 8th, Maseka, one of the Makololo, brought letters to the mission from England, and also a note from Dr. Kirk, stating that Miss Mackenzie and Mrs. Burrup were at Chibisa's, to which place they had been brought in a boat by Captain Wilson of H.M.S. Gorgon, and that he (Dr. Kirk) and Captain Wilson had intended to come up to Magomera, but were lying at Soche's ill of fever, and without medicines. Scudamore, Waller, and myself immediately started to their relief, Scudamore intending to push on without delay to Chibisa's to see Miss Mackenzie, and to make Mrs. Burrup acquainted with the death of her husband. We reached Soche's soon after mid-day on the roth, and found Dr. Kirk and Captain Wilson, who had part of the boat's crew with them, making preparations to return to the Shire. We sent off a messenger to Magomera to bring down to Chibisa's our letters and the Bishop's papers.

Captain Wilson had good reason for wishing to return without further delay, as he had been away from his ship more than six weeks.

While cruising on the east coast he put into Mozambique for supplies, and there found the Hetty Helen, a brig which had on board the sections of a new steamer, the Lady Nyassa, for Dr. Livingstone ; stores for the mission; Mrs. Livingstone, Miss Mackenzie, Mrs. Burrup, and two female attendants ; the Rev. J. Stewart, who had been sent out at Livingstone's invitation by the Free Kirk of Scotland with the view of spying out the land for missionary purposes ; and the Rev. E. Hawkins, son of the Provost of Oriel College, and J. A. Blair, a printer, who were joining the mission. The Hetty Helen had picked up the 
mission party at Natal, had arrived safely at the mouth of the Zambesi, but could not get into the river; had waited about for several days, and being at length blown away by a storm, had made for Mozambique. Captain Wilson took the ladies on board the Gorgon, and towed the brig back to the mouth of the Zambesi, where the Pioneer had arrived.

When the Pioneer was laden with the sections of the Lady Nyassa, she could only take on board a small portion of the mission stores. The rest was left at the Kongone under the care of the Rev. E. Hawkins. When the Pioneer arrived at Shupanga, Captain Wilson, who had waited to give Livingstone the aid of his crew in unlading the Lady Nyassa, \&c., came to the conclusion that she would not be able to get up any farther, and resolved to bring Miss Mackenzie and Mrs. Burrup up to Chibisa's in his gig.

There were rumours amongst the Portuguese that the missionaries had been severely repulsed in an engagement with the natives, and that at that very time the station was besieged by a hostile force; so Captain Wilson resolved to send into the Shire three boats filled with armed men, in order to show the various chiefs that they were within reach of other English if they behaved badly to the missionaries. These boats, however, returned to the sea long before reaching Chibisa's.

Dr. Livingstone informed Captain Vilson that the journey to Chibisa's and back would occupy no more than ten days, but it took him fifteen to get to Chibisa's. The position of the ladies in an open boat for so long a time was most trying. But for the untiring attention of Captain Wilson, Dr. Kirk, and Dr. Ramsay of the Gorgon, Miss Mackenzie would have died.

Burrup left a letter at Malo to be given to any English that might come up the river, but fearing to be held responsible for the Bishop's death, Chikanza did not deliver it to Captain Wilson while he was there, nor did he say anything of what had happened. It was not until they arrived at Chibisa's that they heard that the Bishop wa dead. Of Mr. Burrup's death, nothing was then known by the Makololo.

A slight cessation of fever enabled Captain Wilson to reach Mbame's village, but he could not resume his journey until the 
afternoon of the following day. Waller went on to Chibisa's, hoping to secure a canoe to take him down to the Kongone. Dr. Kirk and Captain Wilson suggested that arrangements should be made with the Portuguese for the bringing up of our stores, as it seemed to them certain that the Pioneer would not be able to do so.

On the night of the Irth Captain Wilson was very ill, and next day his men made a rough palanquin in which he was carried down the hills. He rallied, however, before the day was over, and gave orders to start within an hour of his arrival at Chibisa's, having resolved to take the ladies back with him. By so doing he undoubtedly saved their lives. Miss Mackenzie was too feeble to stand, and was carried down to the boat. Mrs. Burrup was greatly troubled, but bore up bravely against her sorrow. It was indeed a painful providence that had taken from them those to whom they came, the only two of our party who had died ; and one felt that it was only $\mathrm{He}$ who had permitted their affliction who could console them, and reconcile them to their loss.

After an unexampled journey from Magomera, in which he did the seventy miles in twenty-eight hours, Charles arrived with the Bishop's papers and our letters just before Captain Wilson started.

Waller having secured a canoe went down the river also, taking Job with him.

We found the Makololo at Chibisa's revelling in plenty. They had goats by the score, fowls by the hundred, and corn and pombi without stint. They had numerous wives, many slaves, and much cloth. They had passed from poverty to affluence, from a position but little removed from that of bondage to the condition of chiefs. And how had this come to pass? They angered Dr. Livingstone during the journey from Lake Nyassa, and he left them at Chibisa's with guns and ammunition and nothing else. For a short time they were in great straits. But with guns they soon discovered their power. They hunted the Chakundas, took from them their slaves, and appropriated their goods. The women they released they made their wives, the men and boys they kept for their own service. They had 
no sheep, or goats, or corn, but the Manganja had; and as in their own country the possession of cattle by a neighbouring tribe is a good casus belli, they were prepared to make war upon the Manganja for their flocks and corn if they did not yield them without resistance. The Manganja yielded, and thus it came to pass that sheep and goats and fowls, and houses well stocked with corn, and men-servants and maidservants, were found in the habitations of the Makololo.

The English name, consequently, was in bad repute in the neighbourhood of Chibisa's. It was no use to say to the people of the villages near to the Shire, "The English are here, there is no need to fear;" they did fear, and with good reason; for the Makololo were identified with the English. They came into the country first of all with them, they went with them in their journeys, they lived with them, and they took their name in their raids, and it was only when the missionaries were individually recognised that the English were not looked upon as enemies rather than friends. We were greatly pained by the state of things which we thus discovered. The Makololo had always behaved well when with us, or when employed by us; they had many good qualities for which we liked them; but we publicly repudiated their ill-deeds, and took every opportunity of making the Manganja know that they were no longer to be identified with us.

Scudamore and I left Chibisa's on March I 2 th, and arrived at Magomera on the morning of the $I_{5}$ th. Not many days afterwards the old war panic broke out amongst the Manganja; chief after chief came to the station and declared that the Ajawa had assumed offensive operations; but we gave but little heed to their declarations. But if some came to speak of war, others came to tell of peace and plenty. First of all came Bango, the chief of Misaji, a place lying a few miles to the north of Magomera, and with him came a long train of men laden with corn, which he begged the English would accept as a small token of his friendship and gratitude. For had not the English given him all? They gave peace to him and his, so that they had been able to plant their gardens and reap their corn, and he had brought them an offering of the first- 
fruits of his fields. Then another body of men, also laden with corn, entered Magomera. Their leader was Mantongo, the head man of Numyama, chief of Kunumbo, who also said that his lord was grateful, and had sent us a proof of his gratitude. If Bango and Numyama were grateful, so were the missionaries, and with much thankfulness to the Giver of all good things accepted these much-needed presents. But Bango and Numyama were not the only chiefs that were grateful, for Chinsunzi was grateful also, and came to Magomera attended by his son, and upwards of a hundred men, most of whom were burdened with corn. The old chief was arrayed in his grandest apparel, and made a very pretty speech, in which he declared his great and never-ending regard for the English, who had done such great things for him, and his regret that he had not been able to come and see them for so long a time. But he had been busy in the field, and now, having time to do so, he had come and brought a little present with him. The little present was a large heap of corn.

We were glad to see a better side to Chinsunzi's character, for up to this time he had exhibited very little but meanness and mendacity. He may have been grateful, for it was certain that the Ajawa had made his country a desolation, and his people fugitives, whereas his land was then a fruitful field, and his people were content and happy in their security and abundance.

Chinsunzi said that there were no Ajawa in his neighbourhood, and that he was under no apprehension of their returning.

Plenty now abounded in Magomera, but sickness did not greatly decrease. Dickinson condemned the place as quite unfit for our purposes, and he was right, for it was a pest-hole. Consequently it was decided to give it up, as soon as the second year's stores had been obtained. In thinking over the various localities suitable for a station, no place more suitable than Mongazi's appeared to present itself, and Dickinson and Procter went to make the necessary inspection of the country. They returned on March 22nd, and reported that they found Mongazi was much inclined to talk about war with the Ajawa, 
but not unwilling to let us live on his land if we could find a place to suit us. Such a place was found, and as soon as it was possible to do so, it was resolved to move to it.

Furthermore they reported that Kempama, the Ajawa chief, was undoubtedly making war in a mild way, in revenge for an attack which the Manganja under Barwe had made on some of his people. He had burnt a small village, and by so doing had scared the Manganja in its neighbourhood out of their wits. Further inquiries about this outbreak were made, which convinced us that the Manganja had provoked it, and that Barwe, a persistent and splenetic fellow, who wanted to get rid of Kempama, who had been three years in the country, and wished to live peaceably, had been the prime provoker.

On April rst, Mbame, who lived not more than twenty miles from the Shire, came to invoke our aid against the Ajawa. He could not say that any place belonging to him, or near to him, had been molested by them, but he and all who lived round about him were in great fear, because the Ajawa were advancing into the Kujireka district, which lay between hins and the Shire cataracts, and would certainly "eat them all up," if we did not check them. He admitted that Barwe and Mongazi had asked him to come to us, but his statement that the Ajawa were advancing towards his neighbourhood was in harmony with Dr. Livingstone's information that he had seen a large body of that tribe on his return from Lake Nyassa, and was confirmed by Chimlolo, who came to us from some Ajawa that had already penetrated the Kujireka region. This was information which required serious consideration on the part of the missionaries. With reference to Kempama they were quite resolved not to go against him, but this other body of Ajawa might get between them and their communication with Chibisa's. The question, therefore, was, should they attempt to hold them at bay, resist, in fact, the irruption of these people who had been driven by a stronger force from their own country into the Manganja territory, or leave the highlands for a time until the two tribes had come to an agreement in their own way. Our greater knowledge of the Manganja convinced us that even if it were right to help them against the Ajawa, it 
would be useless to do so. The more you helped them the more they would look for help, the less self-reliant they would be. As Christian missionaries we did not think it inconsistent with our duty to succour the distressed, to defend the oppressed, or to rid the land, if we could, of a mere band of robbers and murderers; but we could not see that it was our duty to fight for the Manganja, under existing circumstances. And so we resolved that we would, rather than do so, retire from the highlands and await at Chibisa's the result of the contest between the Manganja and the Ajawa.

Our stock of barter goods being exhausted, we, on April the I4th, sent Charles down to Chibisa's to see if he could get any information of the Pioneer.

On the $x 7$ th the dispute between Barwe and Kempama assumed serious proportions. Day by day we had been pestered by the Manganja concerning Ajawa misdeeds, which, upon inquiry, proved to have no foundation; but on this day we knew for certain that Barwe, having persuaded Mongazi and some other chiefs to join him in an attack upon Kempama, had been beaten, and that his chief village was at the mercy of his enemy.

We could do no other than pity the poor trembling creatures who came to us, and declared that they would never make war again if we only once more drove their enemy away from them ; but we felt compelled to turn a deaf ear to their appeals. They did not attempt to deny that on this occasion they had been the aggressors, and we knew that during the previous five months the Manganja had killed and made captive many Ajawa whom they had caught wandering away from the large camps. At one time we thought of going to the head-quarters of the Ajawa, with the view of getting up a conference between their chiefs and the chiefs of the Manganja, but experience convinced us that the animosity of the Manganja was too great to warrant us in believing that any good result would come from such action. What, therefore, should we do? Remain at Magomera, and see the country about us devastated without holding out aid to the Manganja, or go away at once? The former we could not do, and so we decided to go down to 
Chibisa's, unless we could find a good position near to Soche's or Mbame's. It required a great deal more courage to do this than to shoulder our rifles and go against Kempama, or any other body of Ajawa that might come into our neighbourhood, for such was the superstitious feeling about us, the doing so would have exposed us to very little danger.

We determined upon taking our children with us, and such of the men and women as cared to accompany us. Our numbers were greatly reduced, for since December we had lost more than fifty women and children by death. The Bishop's class of little ones had dwindled down to one, a little boy named Katolatola (drop me down and pick me up), but of the survivors of the other classes some were improving greatly in habits and manners.

On April 2oth, Easter Day, for the first time since the news of the Bishop's death reached us, we sang the Psalms and a hymn; and despite the care and troubles which beset us we were far from unhappy.

On Easter Monday, a man whom we had sent down to Chibisa's with Charles, returned, bringing with him a bundle of cloth, a bag of newspapers, and a letter from Waller. Blair had come up the river with Job, and had brought us some supplies in two Portuguese canoes. Waller's letter was written at Shupanga on March $\mathbf{r}$ th, and said that the Pioneer, unable to ascend the river, had landed the sections of the Lady Nyassa at Shupanga, and had gone down to the Kongone with Captain Wilson and the ladies; and that, "out of the very large stock of stores brought out for us to the Kongone, scarce any of the essentials are left.".

This proved to be literally true. For out of fifty boxes of flour we received no more than eight; biscuits and salt meat were all gone; our cloth had been freely used; out of four casks of wine we received less than one; our brandy had been appropriated, so that there was scarcely any left; and other things were in a like proportion lost to us. What was the explanation of this? Our stores were landed at the Kongone intact, and when the Pioneer and Captain Wilson went up the river, the Rev. E. Hawkins was left in charge of 
them. He was taken ill with fever and was removed to the Gorgon. A storm blew the ship away from the Zambesi, and she did not return for some weeks; the stores, consequently, were left unprotected. The natives at the Kongone may have stolen some. The expedition was not abundantly supplied. It is certain that when the boats of the Gorgon returned from their trip up the Shire, there were ninety sick and hungry sailors left for nearly three weeks without any stores to draw from but those belonging to the mission. Because Bishop Mackenzie, thinking the supply of goats and fowls would not fail, instructed Dr. Meller to sell to the ships any preserved meats that might be sent to us, it seems to have been thought by those at the Kongone that we were revelling in abundance, and that it mattered but little if others than ourselves had the good things which the Cape Town Committee, with so much care and feeling, had provided for us. A little considerate reflection would have convinced those who thought so, that in consequence of our having been obliged to leave so large a portion of our first year's stores at Johanna, there must be a deficiency of food at the station necessary for Europeans not yet accustomed to the food of the country. It is true we were never really without food, but we suffered considerably from the character of that which we were compelled to eat. Pumpkins, cucumbers, and green corn are delicious things as accessories, but they do not constitute the best form of diet for men worn by exposure and hard work, and suffering from fever and dysenteric complaints. Our breaking-in to native diet was too severe. I suffered less than most from this, but it was painful to behold your brethren enduring and sinking under illnesses which would have been avoided altogether, or from which they could have quickly recovered, had they had proper food; had we not, in fact, by want of thought and proper consideration, been deprived of nearly five-sixths of our stores.

We were not inclined, however, to grow morbid in thinking over a trouble that could not be remedied. We received with gladness the bundle of cloth which Charles sent up to us, and were thankful that things were no worse.

April 24th was an exciting day. We were hard at work 
preparing for our departure, when the cry of "Ajawa!" was raised in such a way as led us to think that a horde of these people were advancing upon us, so we snatched up our guns and sallied forth to meet them; but there was nothing visible but smoke, and that was a long way off. We went to a hill from the top of which we saw that it was Barwe's villages that were being burnt, and that a number of people were fleeing from them towards Magomera. As these fugitives arrived it was impossible not to feel deeply for them, they looked so helpless and hopeless; yet we also felt that it was equally impossible for us to take their part in this strife which they themselves had provoked.

Charles returned towards evening with about seventy Chibisians to act as porters, and we resolved to leave Magomera next day.

Chigunda was not surprised when he heard this. At first he expressed a wish to go with us, but after a consultation with a brother chief he said he would stay at Magomera until he was driven away, when he would come down to us.

Early in the morning of the 25 th, we had finished all our preparations, and having visited Burrup's grave, and distributed food to all our people, we gave each man his burden, and commenced our march.

One of our protégés, a girl named Chazika, who was suffering from a malignant ulcer in one of her feet, and was consequently unable to walk, was immoderate in the expression of her grief, until we found a man to carry her, and then she was quite as immoderate in the expression of her joy.

We resolved to go by way of Mount Chiradzuru instead of by Mongazi's, that route being the nearer, and affording two halting-places before we got to Soche's. Scudamore took the van, I the rear. It was not more than ten miles to Bobo's village, where we intended to halt for the night, but the day was hot, and the women and children were very tired before they reached their destination. Bobo and his people were in hiding, but our presence banished their fears, and for that night at least they felt themselves safe. All the huts, with the exception of two, were placed at our disposal, and then there was accommoda- 
tion for the women and children only, so we and our men slept in the open air.

The huge mountains hanging, as it were, over us, and lighted up here and there by the fires that had been kindled, the wild appearance of our people as they ate their evening meal, the discordant din of many voices, and the circumstances connected with our journey, combined to create an experience that could be realised only in a country like Africa.

Next day we moved on to Pingwi, which we found deserted. Adams was the last to arrive; he had developed fever on the way, from which he and Dickinson were seldom free. Constitutionally, however, they were very unlike, Adams being robust, and Dickinson delicate.

The incidents along the road were numerous, and some were pleasing. Our own men behaved admirably, and manifested the greatest concern for the safety and comfort of their wives. The man Chimlolo proved himself an excellent fellow, helping those that were weak, and encouraging all by his hearty word and laugh. When we counted heads at Pingwi it was discovered that two of our lads who had ulcered legs had not come in, so two of our men, Akumtonda and Ntula, went in search of them, and brought them in on their backs.

Katolatola, the sole survivor of our very small boys, marched along famously for about five miles, and then his strength failed him. I found him sitting by the wayside yelling with the fear of being left behind. Having discovered a fellow skulking in the bush, I promised to pay him if he would carry the child to Pingwi, and he agreed to do so ; but three or four miles further on I saw Katolatola deserted and disconsolate. Clark coming up just then, gave his gun to a boy, and shouldering the little urchin carried him into Pingwi.

The next day being Sunday, we wished to make it a day of rest for all, but the Chibisians were anxious to get on to Soche's, so we sent them on with Charles and Gamble.

After seeing Dickinson and all others off on Monday, Procter, Scudamore, and myself, accompanied by William and six of our men, went back towards Magomera, in order to 
bring on some luggage that had been left behind, so we did not reach Soche's until the next day.

A thunderstorm met us on the way, and we were never more wet than when we entered the village. Soche's might have been made charming, but then it was repulsive. Rotting vegetable refuse lay about in all directions. The puddles were expansive and knee-deep, and the village stank. The Socheians seemed to be in good condition; the children were fat ; and no one seemed to be careworn or anxious. But had we stayed here we should not have been free from the Ajawa difficulty, and that was a burden we felt we could no longer bear.

Next day Job came up from Chibisa's with thirty additional men; and as it was raining hard when he arrived, these Chibisians seemed a more miserable set than one had ever witnessed. The natives love neither rain nor wind; but give them sunshine and they expand to the full extent of their capacity. We were all very damp, and all more or less unwell; but Job brought us a bottle of brandy, and so for the first time for six months we were able to comfort ourselves with a little spirit and water. The effects were beneficial. It threw off an attack of fever with which I was threatened, and the rest suffered less than they would have done. Johnson had no more than a table spoonful, but it made him so joyous that he produced his fiddle and drove the Socheians nearly wild with delight.

We moved on to Mbame's next day, Master Katolatola marching immediately in front of me for the whole distance, and talking about the affairs of the country more like an old man than a child of five.

Mbame was sad at the prospect of failing crops, for at his elevation the country was suffering from drought. The first terrace had had none of the rain that had been so plentiful higher up. Our people declared that if we stayed here we should soon be in want of food, so we finally determined to rest for a time on the south bank of the Shire, just below Chibisa's. I started off at once, in order to make preparations for the rest, and arrived about nine next morning. Blair was sitting at the door of his hut eating ground-rice porridge, swimming in milk, and sweetened with sugar. I had never coveted food 
before, but I did covet this, it looked so tempting. I had walked twelve miles without being able to get a breakfast, and I was hungry. So I said to him-

"Are you hungry!"

"No," said he.

"Then turn your breakfast over to me, for I am," replied I ; and he did. What a meal that was! There was not múch of it, but it was so nice!

Blair was not well, he had had fever in coming up the river, and was not recovered from its effects.

I found an excellent position for our station before our party arrived. When Scudamore saw it he said, "This is a glorious place. All we want. High enough above the river, and water easy of access." The bank here was about eighty feet high, and the view from it was beautiful. The soil was good, a light supersoil upon stratified sand. We did not think that this place would prove as healthy as the better parts of the highlands; but we felt sure that it would prove healthier than Magomera. We moved to this place under no delusion, but with our eyes open to the probable consequences of what we were doing. It was the only place to which we could retire until peace was given to the highlands, and we could return to them.

All of our party were down by May 6th. It seemed almost incredible, so thickly had events crowded one upon another, that only a year had passed since we entered the Zambesi. If time were measured by experiences, we should have been ten years older since then. 


\section{CHAPTER VII.}

FOR a few days, until we could get huts built for ourselves, we stayed in Chibisa's village; and the ill-deeds of the Makololo were again brought prominently before us. They had plundered the country around us, and so great was the dread of them that the Manganja were afraid to come to us with food. So we summoned these fellows to our presence, and gave them to understand that unless they altered their conduct we would hold no intercourse with them, we would not allow any of our people to go near them, and that we should let the Manganja know that they were our enemies. Moloko and Ramakukan denied that they individually had plundered or ill-used any one, but they were forced to own that they had a number of men in their service who did both. Moloko said in defence of their conduct, "Well, it is true that we have taken food, and what else could we do? We were left without food, without gardens, without sheep or goats, without anything but our guns. We cannot go to the Portuguese. We cannot go to Lianyanti (the chief town of their tribe). We must stay here. What shall we do then? Die of hunger? No, not while there is food to be taken. All men would take food rather than die."

Nevertheless, before we had done with them, they promised us that they would make gardens and go elephant-hunting, and we promised to sell their ivory for them, and to help them all we could, if they conducted themselves like honest, good men. It soon became known to the Manganja that we were displeased with the Makololo, and that they might come to us without fear, and then food was brought to us in abundance. 
The change from the hills to the valley did our people good. $U_{p}$ to the time of our leaving Magomera death clung to them, a boy named Kasarima died the day before our departure; but now the sickly recovered health, and death seemed to have taken farewell of them. But though beneficial to them, the change distressed some of my English brethren. The heat of the valley was great, and while house-building we were much exposed to the sun. Dickinson, Adams, and Clark suffered most severely, indeed they were scarcely ever free from fever. My health, however, was greatly improved by the change, and so was Gamble's, and after he had shaken off the attack from which he was suffering when I first saw him, Blair was as free from fever as a native.

To our great delight, Waller returned on May 27 th. He brought the remnant of our stores, and some necessaries that he had purchased from the Portuguese. We had less than we needed, but the question of ways and means no longer harassed us. He informed us of the death of Mrs. Livingstone at Shupanga, of the safe departure of Miss Mackenzie and Mrs. Burrup, and of the return of Mr. Hawkins, broken in health, to Cape Town.

The position which we assumed towards the Makololo made them very uncomfortable, and we were not surprised to learn on June Ist, that they had gone away. It was said that they had gone to Doa, to Chibisa. We went to the village and found it nearly empty; with the exception of Chechoma and a few others, they had driven the original inhabitants away.

The day after their departure, eight Ajawa men and their wives, who had been the slaves of the Makololo, but refused to go away with them, came to us and begged that they might be placed on the same footing with us as our other native friends. We were not anxious to have these people associated with us, as they had been connected with the Makololo in their robberies and deeds of violence, and advised them to return to their own people. This they said they could not do, for war had passed over their country, and their friends had been killed or dispersed; and if they went up to the hills they would be enslaved, and probably sold again. They acknowledged 
that while with the Makololo they had robbed the Manganja, but that in doing that they declared they only had done their master's bidding; and they promised to keep the laws that we might make for them, and to do nothing contrary to our will.

We took time to consider their application, and in the interval, Damanji, Akumtonda, Chimlolo, and others of our old friends, begged very hard that we would return a favourable answer to their countrymen, and promised to be surety for their good behaviour. We did not put them on the same footing as the others, but we gave them permission to build near to us, and promised to protect them so long as they were honest, industrious, and refrained from violence.

Our people were improving daily under our teaching and example. Of course what they did different from what they used to do, and what they left undone, was probably owing to no higher motive than the wish to please us; but as we always directed them to a Higher than ourselves, they were, I think, beginning to understand that God's will should be their rule of life.

As soon as we were able we recommenced, and more systematically than before, the study of the language most in use ; and in this part of our work Scudamore acted as our preceptor; for he acquired it more quickly than any of us, and was looking forward to having a religious service for the natives, or rather for our own people.

While we were in the valley we determined to confine our work as much as possible to our people, so that when we returned to the hills they might be in some measure qualified to act as missionaries amongst their own tribe ; for every week it became more and more evident that the Ajawa would soon be masters of the highlands.

We were not to be long in the valley, however, without hearing that hideous word "Kondo!" (war) again; for on the I Ith of June Chechoma came to us attended by a long train of sorrowful-looking Chibisians, and informed us that there had been fighting at Doa, and that the fortune of war had gone against Chibisa, who was close at hand with all his people.

"All his people" proved to be about six hundred souls. 
They arrived a few hours after Chechoma came to us, and encamped in the bush outside the village. The Makololo returned with them, having met Chibisa on the road.

On the $13^{\text {th }}$ Chibisa visited us in state. Having heard so much of the warlike deeds of this man, and not having had his person described to us, we had imagined him to be a man of large stature and commanding appearance; and were surprised to find him a little man, about forty years of age, with a large, long head, and features that in their formation were European rather than African. He shook hands with us as a European would do, and following us into a hut he sat down on a chair as though he had never known what it was to squat. Then he looked at us individually, not rudely, but as one well skilled in physiognomy, nor did he lose his selfpossession for a moment.

We opened the conversation by expressing our sorrow that he had found it necessary to leave Doa, and our hope that now he was here he would stay, as we should be glad to have him for our neighbour as well as our friend. He replied quietly, remarking as he filled his pipe with tobacco-

"I know the English are my friends, and that they feel sorry for my trouble, but I am not going to stay here. This is a poor land. There are no elephants, and no buffalo here. I have brought the women and children here for safety, but I shall return to Doa soon. If Makururu " (the man with whom he was at variance) "comes against me again, I shall go out to meet him. If I die, I die."

We then explained to him our object in coming into the country, to which he listened attentively, and replied-

"My people told me that you came to speak about God, not to fight, and that you left the hills because you wished to be quiet; I know that some white men teach, and some fight."

We then spoke of the state of the highlands, and told him of the want of courage and union amongst the Manganja. Upon which he smiled, and answered-

"They will not fight alone, nor together; and they want me to be their leader! But I have enough of my own troubles. 
I must take care of myself, and they must take care of themselves."

He did not allude to the cause of the quarrel between him and Makururu, but said that he was taken by surprise, and being short of ammunition he was obliged to retreat. We saw that Chibisa's determination and pugnacity had not been over-rated. He spoke and acted like a man who was not easily overcome, and who when he had set his mind to do a thing would not be satisfied until he had done it.

Before he took his departure, as he had always behaved well to us, we gave him a considerable present, and a fathom of cloth also to each of his head men.

In the afternoon we visited his camp. The majority of the women and children looked weary and dispirited; the men seemed to be more fatigued than dispirited; they did not look as though they had been thoroughly beaten. The retreat from Doa had been no rout, for the goats and sheep had been brought off, also a considerable quantity of corn, and a great deal of household furniture; amongst which we saw a cane-seated couch, a chair, a child's cot, and other articles of European manufacture. As Chibisa was said not to deal in slaves, we concluded that these things came from the Portugese in exchange for ivory.

He repeated his visit the next day. On this occasion he wore a scarlet cloth cap ornamented with gold lace, and a richly coloured wrapper. He was, however, less formal in his manner, and was much interested in the various things which we had to show him. Chechoma, no longer the talkative man he was, and shorn of all his gay apparel, for he wore only a goat-skin, attended him. I remarked upon Chechoma's altered appearance and manner; upon which Chibisa gave a little chuckle, and said very quietly-

"Chechoma has been acting the great man; but I looked at him last night, and now you see what he is."

That look must have been highly significant. In the afternoon Waller and I again visited the camp, and found Chibisa lying prone on the earth, with his head a little raised, and surrounded by his principal men. They discontinued their 
conference significantly as we approached, and Chibisa rose and led the way to his own quarters, a secluded place fenced in by trees and shrubs, and there we found his wives and children. Their name was legion, for there were very many. Upon our remarking this he laughed, and said the number of his wives was "Kumi! kumi! kumi !" which means ten thrice told, and as many more as you liked. The children were of all ages, from the young man of twenty to the babe just born : I counted eight infants at the breast, and Chibisa was the father of them all.

When he next visited us he made an urgent request for gunpowder. Said he-

"Without gunpowder I cannot go back to Doa, for if I have no gunpowder I cannot defend myself, and I cannot live. You are my friends; friends always help one another; you have gunpowder, give it to me in exchange for ivory, I have plenty of ivory with me."

That we had gunpowder was true, and that Chibisa should ask us to let him have some was natural, but we had made it a rule not to give gunpowder to any native, and we determined not to make an exception in his favour. When he understood this he looked disappointed and displeased, but said-

"If the other man (Dr. Livingstone) were here, he would let me have gunpowder. He is down the river; will you send a letter to him, and tell him I will give him ivory for gunpowder?"

This we promised to do if we could find messengers to take the letter.

Several days passed, and we heard that Chibisa was in trouble with the people on the Shire. Some of his followers had been stealing food, and one at least of them was killed. His position was a critical one; for he was at variance with Mankokwe, none of the river chiefs liked him, and when they discovered that he had no ammunition they would probably unite against him. He saw that as clearly as we did, and accused us of being the cause of this difficulty; for had we let him have gunpowder he would have returned at once to Doa. 
He did not say this to us, but he did to Johnson and William, and explained to them that he could not send any of his people down the river to the ship, for it would be sending them to death, as all the river chiefs were his enemies.

We felt for the man, and asked him to come and eat with us. He came, and after we had eaten together, we told him that as his people could not go down the river alone, one of us would go down to the ship with them.

"Jekoma!" (that is good!) was the exclamation of himself and followers; who then talked and laughed as though a heavy weight of care had been removed from their minds.

As I proposed this plan, I was anxious to carry it out myself; but Scudamore thought that it would be better for him to go, and the others thinking with him, he went. Job accompanied him, and Chibisa sent three men with three tusks of irory.

Chibisa did not await the return of his messengers, for news was brought by his scouts that his enemy had left the neighbourhood of Doa, and that some of his crops were still standing; whereupon he and his men went off at once. Many of the women, however, remained behind.

Before he left we told him that we had not chosen the valley as a permanent residence, and should return to the hills, as they were more healthy for us. He expressed a wish that some of us would continue to live on his land, and said-

"I know that you come to teach us about God, and to make us a better people than we are. That is very good. When I am over my trouble, I shall come back again if you stay here, and listen to what you have to say, for I want to know about God."

Pending the return of Scudamore, who was instructed to come to some understanding with Livingstone about them, we resumed friendly intercourse with the Makololo, some of whom went elephant-hunting, a drove of these creatures having been reported about twenty-five miles below us.

Having been for some time closely occupied with work at the station, Dickinson and I made an excursion to the Shire cataracts. Our object was thieefold-relaxation, to become 
acquainted with the country, and to see if it were true, as we had heard, that a large number of Manganja fugitives, from the Kujireka district, were encamped on our side of the river above Matiti, the first of the Murchison Cataracts.

We started on July 8th. The morning was favourable for walking, the fierce heat of the sun being modified by clouds. The characteristics of the valley up to Matiti differed in nothing from those in our immediate neighbourhood. Here and there was a large baobab-tree, the grotesque feature of every landscape in that part of Africa; the sterculia, a tree with a stem as smooth and as bright as that of a silver ash, and which, without knob or branch, rises from the ground to the height of sixty or seventy feet, and then develops an umbrellashaped crown of graceful foliage, was more numerous; but the acacia, which, next to the Palmyra palm, is the most graceful tree in Africa, was most abundant. Everywhere there was a profuse undergrowth, consisting of shrubs, prickly mimosa, burnt-up grass, flowerless creepers, with an occasional mass of jessamine, which gladdened the eye with its pure white delicate petals, and gratified the olfactory nerve with its sweet odour. Here and there also we came upon fields of corn that would never come to maturity, being sunburnt and withered, and upon some wild cotton, the precious wool bursting from the pod and looking like frosted silver.

These fields of withered corn filled us with a sad foreboding, for though the supply of food at the station had been good, we felt sure that sooner or later the people about us would suffer hunger, for the principal crop of the valley had failed from want of the latter rain. Chimanga (Indian corn or maize) was not grown largely in the valley nor on the lower altitudes of the highlands, the soil and the climate being better suited to the Mapira (Holcus Sorghum, or Guinea corn), and this was the crop that had come to nought.

After passing through the country which was nominally Chibisa's, we entered upon the land of a man named Somo, and were immediately reminded of the ill-deeds of the Makololo; for the paths were blocked up, and when any of the people met us they ran away. We came to a ruined village, 
and this also was said to be the work of the Makololo. It may have been, but in Africa when once a people have acquired a bad name, every bad deed committed in the land is laid to their account. We were glad, however, to get out of Somo's country, for from some cause or another we were not regarded as friends there.

Machikalonga, the village where we stayed for the night, was on the bank of the river, just below the Matiti Falls. Here we found some fugitives from Kujireka, and very woe-begone the poor creatures looked.

The waterfall was not grand; but some rocks in the bed of the river interfered with the course of the stream, and made a turbulence. That was all.

Next day our road lay over a very rugged country. In one place huge masses of black basaltic rock were scattered about, as though some mountain had exploded and flung its fragments over the land. We did not leave the immediate neighbourhood of the river, and at Sengaro, the second cataract, the Shire assumed the features of a mountain torrent. From this place for several miles the force of the stream was considerable, and as it everywhere met with obstructions, there was a perpetual roar of water. For ten miles above Matiti the country was but thinly peopled; then we came to a large village, near to which was an encampment of Manganja fugitives, of whom there were at least a thousand. When they saw us the men seized their bows and arrows, and the women and children ran off in great alarm. We called to them not to fear, and then one of the men recognised us. He had been to Magomera while we were there, and the revulsion of feeling from extreme fear to perfect confidence made the poor fellow almost mad. He seized our hands, he danced about us, and actually screamed with pleasurable excitement. Of course his friends were no longer afraid of us.

From here, until we reached the place where we halted for the night, the line of fugitives was unbroken. They were encamped along the south bank of the river for miles. On the other side the hills sloped down to the water, and here and there rose abruptly to the height of a thousand feet. Behind 
these hills was the fertile plain of Kujireka from whence these people had fled.

We slept at one of the encampments where a man named Gomi was chief. Food was plentiful there, large quantities of corn being stacked about the camp. The Mapira crop in the Kujireka district was most abundant, and the fugitives daily stole across the river and brought corn back from their gardens. The Ajawa, however, were masters of the country, and so they did this at the risk of the loss of life or liberty.

It was a beautiful night, the air was soft, the moon resplendent. Fires were lighted, and we sat by that of the chief. Dickinson, in the enjoyment of the hour, forgot the sciatica from which he had suffered during the day, and astonished us by his proficiency in the Manganja tongue, and delighted Gomi, his wives and people, with details of English manners and customs. While listening to him they also forgot their troubles ; and light-hearted laughter rewarded his efforts to please them. We did not, however, leave them in ignorance of our object in coming to Africa, but did our best also to make them understand something of God and His love for man.

The men we took with us from the station were excellent fellows to travel with. Their care for us was incessant. Chimlolo's ready wit led him to anticipate our wants, and his good feeling inclined him to provide for them. We knew by experience what he was; and so were not surprised next morning at daylight to find hot coffee, fowl, and porridge ready for us, though to produce such a breakfast at that time of the morning, he must have been at work half the night.

We went on to the Patamanga Falls, and then returned. In coming back we took a more inland route, that by which Dr. Livingstone proposed to carry his steamship. We were but ordinary men, and consequently were amazed at the boldness of the idea. From Matiti we came down the river in a canoe. We were glad to see our own home again. Poor Chazika was hobbling about on her crutches on the cliff, and shouted a welcome to us as the canoe passed by; and a troup of merry children, with affection in their eyes, and "Jekoma!" on their 
tongues, met us at the landing-place, and preceded us to our huts in a state of joyful excitement.

Dickinson had a very severe attack of fever soon after our return, and he suffered so much and so constantly from it that it was evident to all of us that, to save his life, he should return to England without delay. Thinking it possible that we might be able to return to the hills before the rainy season, Waller and I went in search of information, and a suitable locality within easy reach of the river. Our expedition lasted several days, during which we visited several districts likely to suit us; but we were forced to conclude that a move to any one of them was at that time impossible. The Ajawa were prevailing everywhere ; and the only place free from the distractions of war was Mbame's; but rain had not fallen there since January, and famine had already begun.

Dickinson's condition however determined us not to leave any effort to secure a return to the highlands untried, and Procter and Clark explored lower down than we had been. They returned on August ist, and reported that on Mount Choro they had found a site which they thought would be suitable for a station. Mount Choro was consecrated to the spirit Bona, who was supposed to reside on its summit, and the people who lived on and about the mountain were determined that we should not occupy any portion of it. Mankokwe was professedly willing that we should go there; but when Waller went to make arrangements, he found the people in a state of consternation at the very thought of our coming. Nothing that he could say or promise was sufficient to do away with their objection. They dreaded Bona's displeasure more than Mankokwe's, and they were resolved to dare and do anything rather than permit us to come on to the mountain. They were almost mad with superstitious fear; they believed themselves to be living in the actual though invisible presence of a mighty spirit, to whom we were antagonistic, and whose wrath would be visited on them if they consented to our coming.

We were never before so openly opposed by the superstitions of the Manganja. This superstition concerning Bona was connected with the government of the Manganja. The Rundo 
was the supreme chief, but not the supreme authority. Bona was that ; and in times of difficulty and danger, in order to avoid the responsibility of himself deciding what should be done, the chief referred the question to the decision of Bona. This was done through the agency of a woman who was consecrated to Bona's service, and who lived alone on the summit of the mountain. When the Rundo needed Bona's decision, he went himself, or sent his deputy, to the top of the mountain, and declared to this woman the difficulty that brought him there. She retired to the seclusion of her hut, and sought Bona in her sleep, in which condition she received from him the answer he would have her declare, which, when she awoke, she made known to those who were waiting to hear what she had been commissioned to deliver. That was the superstition; and though it opposed us in one direction, we made use of it in another. We pointed out the folly of asking counsels of Bona, seeing he was non-existent, and declared the existence of God, who was everywhere present, whose will we should consult in all things, and whose word we had come to make known.

But though Choro was denied to us, we tried yet again to find a home amongst the hills, and failed. So at last the alternative was presented to us of staying where we were during the approaching rainy season or leaving the country. Of course we resolved to stay, and committed ourselves to Him who was able to defend us from "the pestilence that walketh in darkness," and from "the sickness that destroyeth in the noonday."

Had there been no prospect of our returning to the hills, we should have left that part of the country altogether; but we saw clearly that in a few months we should be able to go back to them; not to the Manganja, it is true, but to the Ajawa, who would be occupying their places; and we had been sent to them as much as to the Manganja, Bishop Mackenzie being consecrated Bishop to the "tribes dwelling in the neighbourhood of Lake Nyassa and the river Shire," and the Ajawa formed one of these tribes.

Scudamore returned on August 4th, in good health, having successfully accomplished the objects of his journey. The 
Chibisians got their gunpowder, not from Dr. Livingstone, but from the Portuguese, who took their ivory in exchange, and the Doctor sent a letter to the Makololo which had the effect of putting them on their good behaviour for a time. With Scudamore came Mr. Stewart, the gentleman that had been sent out by the Free Kirk of Scotland, and he was our guest for several weeks.

Mr. Stewart naturally wished to see as much of the country as he could; so having planned an excursion to the highlands, he and I set out together.

We left the station on August Igth. The country was not looking its best, for a great bush-fire had covered the valley and the lower range of hills with a black ash. For several days before our departure this fire was raging. At first it appeared like a long line of light on the crest of the hills; then in zigzag, angry-looking streams it descended to their base, where it set fire to the luxuriant and sun-dried grass and shrubs of the valley, and a mighty conflagration was the result. The fire extended at one time more than ten miles, and in many places the flames rose higher than the tallest trees. Up to that time I had seen nothing equal to the descriptions I had read of bush-burnings, but this surpassed them.

We did not find Mbame at home; but his wife told us that since they had destroyed Mongazi's place the Ajawa had been less active, though bands of them were constantly prowling about the country. Magomera was said to be untouched, and we resolved to push on as far as it.

Soche did not give us a hearty welcome, and did not want us to stay overnight in his village; but we had made up our minds to do so, and did. Chimlolo told us that Soche was trying to ensure his own safety by aiding the Ajawa against his own countrymen, and that the reason why he did not wish us to remain was, that he expected some of his men to return that night from the Ajawa camp. Want of food was beginning to make itself felt even at Soche's.

From Soche's to Bobo's the land was seemingly deserted of its inhabitants. We found Bobo's village in a dismal condition. In one of the dismantled huts some men and boys 
were crouching round a fire. As soon as they heard our footsteps they ran. Fortunately I recognised one of them as Bobo's son, and called to him ; he recollected me and reassured the rest. Bobo came to us soon afterwards, and did all he could to make us comfortable for the night. He said that no one thought of making gardens, for now that Mongazi was gone, Soche would go, and all would go. They were as already dead.

It was with very sad feelings that I approached Magomera next morning. When about to cross the river we were seen by some women, and they set up a very shrill cry indeed. At first I thought they were afraid, but Chimlolo said, "Fear! it is not fear. Do you not hear? they are calling Atate-(father)." And it was from joy, not from fear, that these women cried out when they recognised me. Then Zachuracami came rushing down the bank to meet us, and seemed overjoyed to see me again. The stockade had been rebuilt, and the boys' dormitory and my house had been pulled down to supply the timber. On entering the gate the women and children again uttered their cries of joy, and danced round me with delight. Poor creatures! they looked famine-stricken, and the whole place seemed to be suggestive of misery and desolation. The Bishop's "palace" was standing, but the cotton gin which the Bishop bought of Livingstone, the most useless of all the things taken up to Magomera, was the only thing in it. Burrup's grave had not been touched since we left it.

Chigunda was fetched from his garden. His outward appearance was much changed; for he had on a frock-coat which Gamble had given him, and he wore the skirt of my Inverness cape, which had been spoiled for my use by the rats, as a petticoat. He confirmed all that Bobo had said, but did not think that he himself was in danger.

"For," said he, "this is the home of the English, and the Ajawa will not touch it. They will burn all others, but they will leave this standing."

My men were anxious to remain at Magomera for the night, but the place was so suggestive of sorrow, I could not stay. IVe slept instead at Nsamba's. 
Had not our food been nearly exhausted, we should have extended our journey in the direction of Mount Zomba, but our supplies were so short that we were compelled to return. We saw no actual signs of war until we got to Mongazi's, and there the evidences of it were plentiful. The crows were hovering about the burnt villages, and we found on the path the remains of a man. There were probably many such lying about.

We were glad to be at Soche's again, after walking at least thirty miles without breaking our fast; for there was no food to be had at Nsamba's, and we were not able to get any on the road.

We slept at Soche's, and made a Sabbath day's journey to Mbame's next morning. We left Mbame's soon after sunrise, and arrived at the station about 2 P. M., having been away just a week.

The result of this journey convinced us that the Ajawa were virtually masters of the highlands, though they were not as yet in actual occupation of them, and that the poverty and misery of the surviving Manganja made it impossible for us to go back to them at that time.

On September 3rd, Procter and Mr. Stewart left the station for the Upper Shire. They returned on the IIth, and had a sad tale to tell of the effects of war and famine. The fugitives above Matiti had greatly increased, but their food had greatly decreased, and deaths from starvation were already numerous amongst them. They all seemed to be in a state of utter dejection, and were lying about on the ground helpless and hopeless.

On September I 2 th old Mbame came down to us looking very haggard. He was on the old errand. The Ajawa were close to him, and he wanted us to go and drive them away. Soche, he said, had the Ajawa living with him, and joined them in their attacks upon the Manganja.

By this time it became very difficult to get food at the station. There had been no rain in the valley for nine months. On the line of the Shire itself the effects of this drought were not apparent; for on the islands and along the banks, at those places which were moistened by the river, Indian corn was continually grown; but on either side of this thin belt of fruitfulness the soil was hard and arid, and the fields were fruitless. 
That a great famine was imminent we saw, and we saw also that unless we could get supplies from the Portuguese we must leave the country, and our people must starve. So it was arranged that I should go down to Shupanga with Mr. Stewart, and thence to Quilimane, if necessary, for stores. But on the I 4 th, the day before we had arranged to leave, a canoe arrived from Shupanga with letters from England and the Cape. The Ariel (Captain Oldfield) brought them to the Kongone, and Dr. Livingstone sent them up. From the Cape we learnt that the Bishop of Cape Town had gone to England to get a successor to Bishop Mackenzie, and that fresh stores were about to be sent to Mozambique for us. It was therefore necessary that arrangements should be made with the Portuguese at Quilimane for a regular transit of stores from Mozambique, and Waller, thinking that was a duty which the committee of the Mission expected him to undertake, resolved to go down the river instead of me.

We urged Dickinson to go home at once, but that he would not do. He wrote a letter, however, resigning his office, and resolved to await the arrival of his successor.

"I cannot leave you men without medical assistance. If God spare me I shall be thankful; if it be His will to take me to Himself, let me die in the performance of my duty!" was his reply to my earnestly expressed desire that he would leave us.

It having been reported that chimanga was to be bought down the river, Dickinson and I went to Mankokwe's. Corn was growing on some of the islands and in some few places on the banks, but the quantity was not sufficient for more than five per cent. of the population. Where the corn was ripening Argus-eyes were watching it; every ear was carefully guarded against the ravages of birds, and the potent kono was there to protect it from the cupidity of man.

The kono is an invention of the medicine-man to punish pilferers. An ear of corn is here and there smeared with a fatty substance, these ears are artfully connected with a band of bark which is then made to pass all round the garden. Should any thief approach, and in any way touch this bari 
band, according to Manganja belief, he will die; he may not die there and then, but he will waste away of an incurabie disease.

Nevertheless the kono did not prevent the owner from watching his crop day and night, and woe to the thief if taken, -a knife was drawn across his throat, and his body was thrown into the river.

Mankokwe professed himself glad to see us, but he could help us to no corn; he, the supreme chief of the whole land, was barely able to give us enough meal for our dinner.

Before we left he said that he was now sure that the English were his friends, and not his enemies. When they first came into the country he thought they wished to take his land from him, but now he knew that they only came to do good. He, therefore, and all his people, were at their service, and the land was before us to go where we liked. Seeing the Ajawa were daily despoiling him of his territory, this expression of generosity was not worth much.

Old Chimbeli accompanied us to the canoe, and on the way said, all the trouble in the land was owing to the Rundo not doing as Rundos did in days gone by. Then they went from village to village all over the land every year, and at each place they prayed to Mpambi (Manganja name for God) to send rain, and to keep away enemies. Then the people were happy; there was no war, no hunger; but now all things were against them, for the Rundo cared for nothing but his pombi and his wives; and shut himself up with them, got drunk every day, and would go nowhere.

As we returned we landed at the various islands and places where corn was growing, but only at one place were we able to buy any. Here we saw a pretty woman on an island smoling a pipe. I had some glittering brass chain and held it up before her, and showed her what a nice necklace it would make, and expressed a desire for corn in exchange for it.

"There is no corn, there is no giving in exchange," said she; but she looked wistfully at the necklace, and at length her desire for it became so great that she said she would ask 
her husband if she might give corn for it. The result was the same as it would have been at home,- - the woman had the necklace and we had the corn. I felt rather ashamed of having ministered to the vanity of this woman, but the little ones at home were hungry, and though the corn I received was not a meal for half of them, it was something.

The children looked rather woe-begone when they found that we brought so little corn back, for all that we could give them was one cob each. Next day, however, Charles was more successful in another direction; and so day by day we went on struggling for the life of those committed to our care.

We tried to hunt for them, but the heat had become intense, and we could not stand the exertion of hunting. We shot birds, and looked out for crocodiles and hippopotami, but all the people were doing that, and the beasts became so cunning we could rarely get a sight of them.

But despite the great heat, the health of the mission party in October was better than it had been before. Dickinson seemed to be getting quite well, and though some others had fever, the attacks were feeble in character and of brief duration.

On October I 5 th, having heard that Mikaronko, the capital of the Nungwi, of which tribe Kapichi, an old ally of Chibisa, was chief, was a place to which people went for corn in times of scarcity, as the men of old went to Egypt, I and William and twelve of our men started for this abode of plenty. It lay, as far as we could calculate, fully fifty miles to the north-west of us, and was on the high-road to Tete.

We were late in getting off, the sun was high in the heavens, and the heat already very great. When about twelve miles from home the ground was strewn with masses of dark basaltic rock, near to which the atmosphere showed $140^{\circ}$ of heat. We had to pass over several miles of this distressing country, and my men complained dismally of the "Jira chæipa" (very bad road), which tried their feet severely. Then we entered upon a more fertile district and an easier road, and at length came to a large but dirty village, where we rested.

Beyond this place the country was again rugged and rocky, 
and then we began the ascent of a low range of hills, on the other side of which was the plain of Mikaronko. These hills were not high, but they were extensive and barren, and only once between our resting-place and where we intended to halt for the night did we find the means of assuaging thirst. We dug a hole in the sand of a dried-up watercourse, some water collected in it, and with greedy lips and parched throats we drank and drank, until our thirst was assuaged. Here I first really understood what water is to a thirsty man in a dry land. Had we known of the scarcity of water on this road we should have carried some with us.

We halted for the night at Michirinji, where food was not plentiful, but where the chief nevertheless sold us a goat, in the enjoyment of which my men forgot the discomforts of the day.

For more than three hours next day our way lay over the hills, and then we came to a very fine view of the plain of Mikaronko, which, compared with the country through which we had passed, like that of the Jordan, looked "well watered everywhere." To the Mwanza and another river is owing its superior fertility. A range of thickly wooded hills bounded it on the other side, and beyond these, many miles away, we saw the crests of mountains that must have been at least ro,000 feet high. Altogether this was as fair a scene as any I had beheld in Africa. We passed through several villages, in one of which we saw two young men who formerly lived at Chibisa's, and who had been driven away from there by the violence of the Makololo. In none of these places were the people friendly, and though they had plenty of corn they would not sell us any. But nothing of importance occurred until we came to a village of which Chinkoka was the chief. Here to my surprise I found many old acquaintances who had disappeared from the neighbourhood of our station. I rejoiced at this, thinking that my journey was ended, and that my corn-bags would be filled here, for of corn these people had plenty. But my rejoicings were very short lived, for these people were even more unamiable than the others we had met with. I was annoyed at their behaviour, but did my best not to show it, 
hoping to bring about a better state of things. But it was all in vain; they did not want me there; nor would they give me corn in exchange for my cloth. I became angry at last, and was about to give Chinkoka a scolding, when Kongo my guide came to me in a state of great excitement, so great that he could scarcely speak, and said, "I can go no farther with you, I am sick here," laying his hand on his stomach; "I have no more heart, I am dead. They tell me that I have done wrong in bringing you here, and they say that they will "-here he drew his hand significantly across his throat. "If you go to Mikaronko, you will not be allowed to enter the village; as soon as they see you, the drum will beat, and it will be war." Here the poor fellow, overcome by his fear, shed tears.

"But why is this? What have we done to be treated in this way?"

"You have done nothing, but the Makololo have. The people you see here were driven from their homes on the Shire by the Makololo, who took away their corn and their goats, and threatened to shoot them; and they think that now you have come here, the Makololo will come also, and they are angry with me for bringing you, That is why they will sell you nothing."

"Save us from our friends!" we missionaries had indeed good reason to say. I could no longer feel angry with these people, for, according to their point of view, they had good reason for being angry with me. So I endeavoured to make them understand the true position in which we stood to the Makololo; and they admitted that the ill-usage which they had received was when we were in the highlands, and that since we had come down to the valley the Makololo had not behaved so badly. I told them that was because, when we found out what they had been doing, we were angry with them, and when they came to us and said they had no food we gave them cloth to buy with, rather than let them steal from the Manganja. They said that was good. Whereupon I replied, "Can you tell me of any one act of the English that has not been good towards the Manganja? If Chibisa is in trouble, to whom does he come? to the English. At this very moment his sons 
are at our place asking us to help him against his enemies. (That was so.) And yet when our children are hungry, and we come to you to buy a little corn, you treat us like enemies. That is very bad."

Chinkoka, the chief, a stolid-looking individual, here moved about as though on an uncomfortable seat, took a pinch of snuff, and then became as impassive as before; but the rest. of the people showed more excitement, for this news about Chibisa was fresh to them. At this juncture an old man, who was in authority when we first arrived at Chibisa's, made his appearance. I knew him well, and had shown him kindness before I went up to Magomera; he had not forgotten it, and he now made a speech in my favour. Then turning to me, and laying his hand on my shoulder, he said, "The Makololo have done us much harm. Do not let them come here. It is a bad thing to be driven from our homes, and to have all we possess taken from us." Then turning to Kongo, he said-

"Do not fear. Go to Mikaronko with the English; no harm will come to you." After which he took my hand and invited me to his hut to drink pombi, for, said he, "I want my wife to see my good brother, the Kasisi." (Literally the without hair.)

Good old heathen! I felt very grateful to him. Just as we were leaving, a man brought two small baskets of corn as a present from Chinkoka, which I felt inclined to refuse, but my old friend, Nchuru Bango, divined my thoughts, and said, "Take it, take it, we can talk of buying when you come back." So I took it, and sent back a present exceeding its value.

Kongo recovered confidence, and we resumed our journey, arriving at Mikaronko about 5 P.M.

This village occupied a larger space of ground than any I had seen in Africa, and was surrounded by large trees and impenetrable bush. It consisted of circles of huts, family residences, which were situated at some distance from each other. Each circle was surrounded by a high wall of grass. The huts were well built, and the village was free from vegetable and other refuse. The chief's circle was in the centre of the village, and his hut was higher than all the others. 
As we entered, the people came out of their enclosures to look at us, and "Anglesi" passed from mouth to mouth, not exactly in welcome, but certainly not in anger. They looked well fed, they were well clothed, and they wore necklaces of beads, and bracelets and anklets of ivory and brass.

We went to the kotla-tree, a magnificent acacia, with branches that had, as I found, an outspread of $15^{\circ}$ feet. Men and boys crowded about us in a semi-friendly sort of way, as willing to give us welcome, and yet uncertain whether they might without offence do so. Seeing a knot of elderly men a little way off, I sent William, who was skilled in African diplomacy, to make known to them the reason for my coming, and to use our intercourse with Chibisa as a means of securing Kapichi's favour. He succeeded; for, though the chief was not to be seen till the morning, a hut was placed at our disposal. As soon as it was known that the chief had welcomed us, every one became unmistakably friendly, and vied with each other in showing us attention.

Early in the morning Kapichi sent for me. He was a tall, burly, low-natured fellow, just the sort of man to bully you unless you made him afraid. When he came out of his hut, a chair was brought for him to sit upon, and he in a very rude way kicked a mat towards me for my accommodation. So I set my teeth together, looked him hard in the eyes, and kicked the mat away from me. He lowered his eyes in confusion, and I then sent Chimlolo for my rug, upon which I seated myself. Then we sat facing one another in silence for some time, until, indeed, he became restless and uncomfortable. At length he said,

"What brings you here? Speak, and tell me what you want."

"You have corn; we need corn; for until our boats return from Quilimane our children are hungry. Chibisa is your brother, Chibisa is our friend, so I come to you for corn, for which I will give you cloth," said I.

"Who told you we had corn? We have none to sell. You came for something else," replied he in a dogged tone. And he looked so unamiable, that William remarked- 
"I no like that man. He look as though he got something black in his heart."

I knew that he had corn in his gokwas (store-huts), and so replied-

"I want corn, nothing more. You need not sell it unless you like, but if you do not, we shall know what to think of you; and we shall know what message to send to Chibisa when he sends again to ask our aid."

"Did you come for nothing else?"

"We English say what we mean, and mean what we say; we do not lie!"

He looked hard at me for a few seconds, and then became less aggressive in his bearing; and I was glad to hear him say,

"How much corn do you want?"

"My bags filled."

Upon which he jumped up, and shouted rather than said-

"Ah! I want to see what you have got in your bags-something to show me-something to give me-come along!"

And he ran off towards my hut. He had evidently heard of things that we had at the station, for some of Chibisa's people were at Mikaronko, and thought I had brought something wonderful with me.

"Bring out your bags," said he, as I entered the hut"bring out your bags, quick-let me see what you have. I want a bottle. I want a cup like Chibisa's. I told Tambala (a Chibisan) to tell you to send me a knife and a spoon like you gave Chibisa. Give to me! Give to me!"

And he looked inclined to bully again, so I replied-

"We give to whom we like, and to no one else. You want to see something? Behold!"

And I showed him my revolver.

"A little gun!" said he contemptuously.

I put him aside, and fired-once, twice, thrice ; and his eyes were opened in astonishment. Three balls from one barrel, and without reloading. It was astounding. I fired again, and he collapsed. He put his hand on my arm, and said in an awe-struck voice,

"Wina?"-(Again?) 
"Aye !" said I, "Again !"

And be evidently thought that I could go on firing to any extent, and came to the conclusion that he had better be friendly. So he sat down, and informed me that corn was not really plentiful with him, for the crops had been bad, and all people were coming to him for food; but if I would send my men to the villages where the corn was, he would send his head man with them to tell the people to sell. Then I gave him a piece of red calico, and a brass necklace for his wife; and he had breakfast with me, and drank cup after cup of coffee until we were obliged to have another brewing. When he left we were seemingly the best of friends.

The result was, we got as much corn as we could possibly carry home ; and when I said farewell to Kapichi, he gave me a leopard skin, and invited me to come to him again.

We were greatly tired by the heat and the hardships of the way on our return. All who went that journey were foot-sore, and hobbled about for several days, afterwards.

While we had been away our little ones had fared better than I expected, for Scudamore had killed and secured a crocodile ; and as, upon investigation, no beads, or bracelets, or anything else indicating that the beast had fattened on human beings were found in it, they did not object to eat it ; and so things were looking cheery.

On the afternoon of October $25^{\text {th }}$ we heard the Shupanga boat-song, and presently there appeared a large canoe laden with corn and rice, which Waller had sent up under the care of Maseka, the Makololo, who went with him to sell the ivory which he and his companions had got by hunting. This timely supply relieved us from all immediate apprehension of want.

Waller had gone to Quilimane.

These distractions greatly interfered with our mission work, properly so called. We could do little more than keep things together. Yet we were getting more influence in the land, and our people were improving; so there was good hope of more satisfactory results in time. 


\section{CHAPTER VIII.}

FOR many weeks we had been looking forward to the November moon, for then, said the weather-wise amongst the natives, rain will surely come : but the November moon came and the drought still continued in the valley. Clouds did occasionally collect, and storms seemed imminent, but the attractions of the hills proved irresistible; the clouds rolled away, and spent themselves on the mountains, leaving us a clear sky, from which descended an "unclouded blaze of living light." And the November moon waxed and waned, and still there was no rain.

On November 5 th Waller returned, having been away seven weeks. His exertions had been great, incessant, and successful ; and he returned with three canoes laden with corn and rice, cloth, and other things necessary to our welfare. We had also purchased a large canoe, which, whether we were on the hills or in the valley, would be of great use to us. We went into our chapel to return thanks for his safe return, and for God's mercy towards us as manifested in the bountiful supply of food which we had received.

We were now compelled to supply our people with food, for it was useless to give them cloth ; they would go many miles to buy a little food for themselves and families, but it was rarely that they got it. Before Waller's arrival they endured hunger with much fortitude upon the whole, and with patient honesty.

Towards the end of November the famine became sore in the land. There was not a village about us where people had not died and were not dying of starvation. At first those who died were buried; then the survivors being too weak for the 
exertion of grave-digging, carried the bodies outside the village and laid them decently under a tree; if a man, his bow with the string cut was placed beside him; if a woman, the fragments of a broken water-jar ; but as time went on, even this attention to the dead became impossible, and where the people died, there they remained. The putrefying remains of human beings were lying about the paths and in the villages.

The Shire was literally a river of death. Poor hungry men and women would come from the hills, and from the faminestricken parts of the valley, and attempt to steal the corn that was growing by the river, but the owners, with wolf-like vigilance, caught them, and with wolf-like ferocity killed them and then threw their bodies into the water. Mothers having no food to give their children threw them into the river, and jumped in after them ; and men also jumped in, having thrown their wives before them. The crocodiles were gorged with human food.

The distress was so terrible that we resolved to get up more corn from Shupanga, and distribute a portion of what we had to the people in our immediate neighbourhood. Two men were found willing to take a letter down to Senhor Vianna, with whom we dealt, and we dispatched them on their errand. Relying on this supply, we began to distribute small rations of corn amongst the survivors in some of the most necessitous villages close to us. The hopeless, half-idiotic condition to which many of the people in these places were reduced made us realise to the full that "they that be slain by the sword are better than they that be slain with hunger." So extreme was their need that we almost wondered that that most hideous of all hideous expedients, cannibalism, was not resorted to in order to prolong life. For if in olden times the "tender and delicate woman," who "would not adventure to set her foot upon the ground for delicateness and tenderness,"-if this woman who knew of the God of heaven and earth, had an evil eye turned towards the husband of her bosom, and towards her son, and towards her daughter, and did in the extremity of her hunger "devour the fruit of her womb for the sustenance of her body," it would not have been surprising if the poor famishing heathen creatures about us had followed her example. But they did not. Canni- 
balism seemed utterly foreign to their nature. That cannibals exist in Africa we know, but in that part of Africa where we were, they were unknown.

On December 3 rd the clouds gathered, the lightning flashed far away incessantly, the distant thunder kept the air in a continual agitation, but no rain fell until the afternoon, when the tempest rushed upon us, and after a period of eleven months the rain came, such rain as I had never before seen. The lightning almost blinded us, the thunder seemed to make every nerve in our bodies vibrate, a hurricane of wind lashed the river into wave and foam, tore up trees by their roots, and dismantled villages; yet above all this turmoil we heard the shrill cries of women, who rushed out of their huts and ran about like maniacs for very delight that the rain had come at last. But their joyful exclamations mingled with the cries of the dying, for at the very time the storm came down upon us, four of our lads were crossing the river, the canoe was upset, and one of them was drowned.

The storm passed almost as suddenly as it came; the clouds rolled away in gloomy grandeur, and the sun was again paramount. But the rain had done a good work; it had fitted the earth for seed, and those who had seed rushed off at once to their gardens and commenced sowing. But many had no seed; in their hunger they had eaten their seed-corn, and before the day was over, and during the following days, poor famished men and women dragged themselves to our doors, and cried, "Give us seed, fathers!" Some-marvellous in. stances of self-denial and hope-sowed what we gave, all meant to do so; but the cravings of. hunger overpowered others, and they ate, they did not sow. Those who sowed and those who ate, however, both died. Had the rain come at the usual period, the pumpkin crop would have been harvested in November, but the seed was not sown till December, and then it came to nothing; for though on the $5^{\text {th }}$ we had rain again for several hours, and occasionally all through December and January, it was not sufficient to bring the early crops to perfection.

On December 6th, to our great vexation, the men we had sent to Shupanga with an order for more corn, returned, having 
gone no farther than the Ruo. A Portuguese rebel, named Mariano, was said to be plundering down the river, and the courage of these men failed; so they left the canoe at Malo, and returned by land. This made it necessary for one of us to go down to Shupanga, for it was plain that we should need more corn before we could reap a harvest. Johnson offered to go, but Dickinson forbade him, as he had been suffering from a slight congestion of the brain; I volunteered to go, but Procter would not let me; he decided to go himself. He left on the 9th, taking Chimlolo and his own little attendant, Sambani, with him.

A great change came over the face of nature after the rains of the 3 rd and 5 th. The earth was covered with verdure; the trees became beautiful in their prolific foliage; vegetation of all kinds sprang forth with a vigour and abundance unknown to more temperate climes. The fertility of the earth after its long season of barrenness seemed marvellous. We could almost see the grass grow; and seed germinated, and the blade was a few inches above the ground, in the course of a few days.

The Makololo worked hard in their gardens; but the misfortune of their position was this, - to get gardens they had to dispossess the original owners. It is useless entering into particulars, but they did undoubtedly aggravate the misery of the surviving Manganja in our neighbourhood by their proceedings; yet I could not help liking these men, notwithstanding the trouble they gave us, for they were a brave set of fellows, and had we needed their assistance at any time when we were in the Shire, they would have given it willingly. Among such a people as the Manganja, they would never be less than masters ; before we left the country they had raised themselves into the position of chiefs; and the survivors of them, I hear, are now the lords of the whole country between Mankokwe's and Matiti.

Another cause of fear came upon the poor Manganja in our neighbourhood. Chibisa had got into trouble with a half-caste Portuguese, who kept him a prisoner in his own village, and many of his people left him, in consequence, and came to the 
Shire. They wanted food and garden-ground, and they managed to get it, and lived while others died.

The sufferers frequently appealed to us to right them, and we did what we could for them; but hunger and the prospect of death had made men reckless. Right was nowhere regarded. The strong hand and the strong will prevailed. Those who had, kept if they could; those who had not, took if they had the power.

Our own people, however, were a great consolation to us; they were far from perfect, poor things, yet they afforded a marked contrast to others. We managed to purchase good gardens for them, and they went to work upon them with a right good will, and steadily pursued the path of honest industry which we had marked out for them. It is true they were not exposed to the same temptations as many others, for day by day we gave them just sufficient corn to keep them in life; but their steady course of conduct in times of excitement and lawlessness proved that we had not cared for them in vain. Once, however, we had to proceed with severity against one of them, a young man, named Kandalira, who had as good a garden as the rest, but who coveted another piece of ground, and, in order to get it, had, we were told, thrown its owner, a boy, the sole survivor of his family, into the river. We put Kandalira on his trial before a jury of his own countrymen; he was an Ajawa, and he was convicted by them on evidence that there was no gainsaying. We told them what was the punishment for murder in our own land, but that we did not propose to punish Kandalira in that way, as he was ignorant of our laws : but we burnt down his hut, and would not allow another to be built on the site of it; we sent him across the river, made him an outcast like Cain, and threatened to flog him severely if he dared to come near us again. His companions begged for mercy for him, but we were inexorable; and the report of our proceedings in this case spread through the land, and told greatly in our favour.

The great change caused by the rain in the condition of the atmosphere made Scudamore very ill. For some time he had been suffering from diarrhœa and a disordered liver, and now 
fever of a very severe kind supervened, and his condition alarmed us greatly; for his stomach rejected the medicines which were calculated to give him relief. On December 23 rd Dickinson feared that he might at any moment lose consciousness, and advised me to acquaint him with the danger of his position. He was fully alive to it, and with a serene mind dictated his last wishes.

It was difficult to be happy on Christmas day, for we were wearied with watching and anxiety, and dear Scudamore was not better. On St. Stephen's day he seemed to improve a little, but on the night of the 28 th a great change for the worse took place, and his condition seemed hopeless. Delirium set in, and, with brief intervals, continued until his death. But his spirit did not cease to commune with heavenly things. On the afternoon of the 3 rst, when he could scarcely breathe, and his strength seemed to be quite exhausted, the cloud upon his mind cleared away for a few minutes, a gleam of divine satisfaction shone from his eyes, and he murmured several times, "There remaineth a rest."

Having been up the previous night, and Dickinson and Waller being both much worn, we deputed Clark to be with Scudamore from 9 o'clock P.M. till midnight. When Waller relieved Clark he saw that a great change had taken place, and he called up Dickinson, who did what could be done, as a last effort, to stimulate his failing powers; but without avail. Waller then summoned me from my sleepless rest to behold the last moments of one who had been to me more than a brother,-an example of what is desirable in a man, and lovely and of good report in a Christian. The Southern Cross was shining brightly over the hut in which he lay, and, though my heart was sorrowful, when I looked at that cross I thought of the Cross of Calvary, and was comforted.

He died at ten minutes past four on the morning of January Ist, 1863 .

Dickinson chose his burial-place, a lovely spot close to the station, which commanded a beautiful view of the river, the valley, and the ascent to the highlands; just such a place as he for whom it was chosen would have selected for himself. 
We lost much when we lost Scudamore. As a companion he was charming. His amiability was invariable, and his quiet, genial wit was a cheering element in our life. His influence for good on every subject we discussed, and in all the work we had to do, was very great. He knew more of the Manganja language than any of us, and had he been spared he would soon have commenced a regular religious service for the natives. Had he been a less reverent man, he might have done it months before he died; but the fear of doing harm when speaking of divine things, led him to defer doing so until he was more certain that he could speak of the truth without ministering to error.

The natives showed much sorrow at his death; our own people, and the Manganja and the Makololo, made his funeral an occasion of mourning, that seemed to us very real.

The rains were abundant in January, but the heat, when the sun had play, was distressing, more so indeed than during the fine days of the dry season. Famine still prevailed. Wild-looking men, worn almost to skeletons, and with cords tied round their waists to lessen the pangs of hunger, roamed about, grubbing up roots, searching for anything that could be eaten, until unable to go on any longer, they sank down and died. Before January had passed, more than half the inhabitants of the Shire valley and the first range of hills had died of starvation.

Such a famine as that was most rare. Not one of the natives could recollect such a visitation, though some had heard of a "Magumanya," a time when people perish "heap upon heap" for want of food; but it was a long time ago, so long that it had come down to them as a tradition. There is, however, rarely a season in savage Africa when people do not die of hunger; but such deaths are the result of war, imprudence, or some other preventible cause. With Christianity would come law and order, security for person and property, and stores of food to fall back upon in times of scarcity, and deaths from starvation would be then as rare there as in England.

On the evening of January 2 Ist, Chimlolo, with three canoes laden with corn, was reported to be between the station and 
Mankokwe's, and in due time he made his appearance, having performed his duty faithfully and well. He brought a letter from Procter, which amongst other things informed us that stores for I 863 were at Quilimane whither he was going, and that the Pioncer, after making another trip to the Rovuma, had returned to Shupanga. Chimlolo said that there was nothing but hunger all the way down the river.

This fresh supply of corn enabled us to re-distribute rations three times a week to some of the surviving but starving natives who were living close by us. There was one village, Maduga, about a mile from our station, from whence we used to get many of the men that we employed as porters, to which Waller and I went as snon as we received the corn; and our experience here will serve to show what the condition of the country was at this time. We had not gone more than three hundred yards from the station, before we came upon the corpse of a boy who had fallen down and died of hunger but a very few hours before; a little farther on was the body of a man that was nearly reduced to a skeleton by the ants; and when we arrived at the village we saw the body of another man who had died that morning from starvation.

As soon as our object in coming was known, the wretched inhabitants came out of their huts to welcome us. Men who had carried heavy burdens for us up the hills with ease, tottered towards us attenuated beyond recognition; others, too weak to stand, dragged themselves along on their hands and knees; women in the prime of life crawled to the doors of their huts, and could get no farther; and the little children were in such a horrible condition from long famishing, that the sight of them was more than we could bear.

We were not able to save more than five or six of the people of Maduga ; the long privation they endured, and the disgusting things they had devoured to allay the pangs of hunger, brought on dysentery, and the village was depopulated.

With such a state of things around us it might be supposed that we should have been exposed to constant depredations from the starving. It was not so. Now and then a poor 
creature would try to steal food from us, but such instances, considering the present necessity, were very rare. With a few the propensity to steal became a monomania. The most remarkable instance that came under our notice was that of a boy belonging to Maduga, who was about eleven years of age. $\mathrm{He}$ kept us for a few days on the look-out. There was not a hut at our station from which he did not manage to steal something. When we took him out of our village he was back before we were, and was again trying to steal. He seemed more like an autornaton, a thing that could not resist the impelling power, than a human being; and when detected he manifested no shame, and showed no fear. At last we decided to keep him tied up in our village, and hoped, by plentiful food and physic, to cure him. But he managed to free himself; and though he had eaten until he could eat no more, he forced his way into our store hut. Of course this was the result of disease, and the poor child died. But only such as he attempted to rob us.

It might also be supposed that, being the slaves of superstition, the people might have attributed the famine to our presence in the land. They did not. They had received nothing but good from us, and it did not seem to occur to them to connect us in any way with the evil from which they were suffering.

Early in February the people were eating the corn that was grown in the gardens by the river. Of course these gardens were productive of much contention. The Manganja who owned any of them had great difficulty in holding them against the Chibisians and others, and at last to secure them from depredation we took all those Manganja gardens under our protection, - who touched them touched us, and so they were left to their proper owners.

On February I 5 th, Mr. Richard Thornton, the geologist, who had lately returned to the Zambesi, after a successful expedition in conjunction with Baron von der Decken, to Kilimanjaro, the snow-clad mountains, arrived at the station. $\mathrm{He}$ informed us that the Pioneer and the Lady Nyassa were hard aground in the neighbou:hosd of the Ruo, and that Procter, 
when the ships left Shupanga, had not returned from Quilimane.

Mr. Thornton was a great acquisition to our party. His frank, genial, and generous character soon engaged our sympathies in his behalf; and we were glad to know that he purposed to make our station his headquarters while he made theodolite observations of the country about us.

On February 24 th Procter returned, having been away eleven weeks. He brought up stores and medical comforts of all kinds.

The news from home informed us of the condemnation of our proceedings against the Ajawa by many of our friends in England. The committee of the mission, however, expressed confidence in us individually and collectively. None of us were surprised that our action with reference to the Ajawa had been denounced, knowing, as we did, that those who denounced it were quite unable to understand the state of things which made it appear necessary to us, and the motives which actuated us; but we were very thankful that the Bishop and Scudamore were removed from the pain which the words used by some in condemning us would have caused them.

We sent Charles, William, and Job down to the coast with the canoes that came up with Procter, and in due time they found their way to Cape Town. These men had worked well for us in many ways; they had been of great assistance to us, but we could no longer trust them. The temptations of their position with us were too powerful for them, and for their own sakes, for we had excellent characters with them as good Christian men, as well as our own, we resolved to dispense with their services.

By the end of February war and famine had done their work, and probably ninety per cent. of the Manganja in our district were dead.

Procter brought no meat with him, preserved or salt; our stock of goats was exhausted, and no more could be had nearer than Tete. Dr. Livingstone was as badly off for fresh meat as we were, and Mr. Thornton, who was known to the Portuguese at Tete, and who wished to complete his observations of the 
country thereabouts, offered to go to Tete with either of us, and to do what he could to get sheep and goats for the Mission and expedition. We thankfully accepted his offer, and I agreed to go with him.

We had some difficulty in getting off. We wanted a guide and men to carry our food and baggage ; but besides our own men there was scarcely a man round about in a physical condition fit for the journey. At last we found a guide amongst the remnant of Chibisa's people, a gentleman in reduced circumstances, who would carry no burden himself, but had no objection to see his own son, a lad about fourteen, laden like a donkey. Of our own men seven were sick, the rest were watching their fast-ripening corn, and we had no wish to take them to Tete, for with two exceptions they had been rescued from Tete slave-dealers. But we were compelled to have their aid on this occasion. So I called them together and informed them that Mr. Thornton and I were going to Tete for sheep and goats, and that I wanted some of them to go with us. When the terrible word Tete was mentioned, they seemed thunderstruck, and a doubt of our professed object crossed their minds-Were we, after all, going to sell them for slaves? But the doubt passed quickly; Chimlolo volunteered to go, then Damanji, then others, until we had, not as many as we needed, but as many as we could conscientiously take, for the rest were really wanted at home to look after their own gardens and the gardens of those who went with us. Thornton took his own two men and a boy that he had brought from Zanzibar.

According to geographical measurement Tete was a hundred miles from our station, but by the road we had to travel, certainly not less than a hundred and fifty. We therefore calculated upon being away a month.

We started on February 27 th. We left those at the station far from well. Clark was suffering so severely from fever that I feared he would not be alive on our return. Dickinson was very feeble. As we were leaving he ran after us with a small bottle of spirits in which he wished me to preserve any entomological curiosity I might meet with, for he was an ardent naturalist; 
indeed his ardour in the pursuit of insects and birds frequently led him into localities that he should have avoided, considering how subject he was to fever. He followed us some distance, giving us kindly and useful hints about caring for our health, and uttering affectionate last words.

We took Blair with us as far as Mikaronko, where Kapichi received me as an old friend, hoping to be able to buy a few goats there, but there were none to be had; indeed a skinny fowl and a few ears of corn were all the food that we could purchase ; and Kapichi said that hunger was so prevalent amongst some of his people that he had been losing by death from this cause as many as ten a day. Chimlolo, however, explained that those who died were not Kapichi's own people, but destitute Ajawa and Manganji who had come to Mikaronko, hoping to find food.

The hardships of the way had so distressed Thornton and his men, who had of late been more used to travel by water than by land, that we resolved to rest a day at Mikaronko. Beyond Mikaronko the road was less rugged, and the remainder of our journey to Tete presented no great difficulty to us. The country was thinly inhabited, and most of the people were suffering from want of sufficient food. In some districts through which we passed game was plentiful. We saw deer of various kinds; a huge wild boar plunged across our path; a leopard sprang up almost at my very feet, and bounded away in a great fright; in a village where we halted for an hour or two the people brought in while we were there the remains of a buffalo which a lion had killed the night before just outside the huts; and we fell in with a party of natives from Tete who were engaged in elephant-hunting.

The appearance of Tete from the north bank of the Zambesi, which is here fully a mile broad, is not striking. The houses are large, well built, and of stone. The streets run parallel to each other and to the river. Behind the town, parallel with it, but extending on either side far beyond it, is Mount Caroera, a hill of sandstone between 2000 and 3000 feet high. As is the mountain, so is the soil upon which the town is built, and so are the houses, brown and bare. In consequence of this 
uniformity of colour, at a short distance from it Tete can scarcely be distinguished from the soil upon which it stands.

Many cattle were feeding upon the stunted herbage by the brink of the river. Some of these beasts were fine animals, and would have been no discredit to an English farm. These lusty brutes were a pleasant sight to a man just arrived from a country of leanness and famine, and their bellowing was equally pleasant to the ears.

We were received most hospitably by Senhor Clementina, a man whom Thornton knew, and we had not been more than an hour in Tete before the governor sent a soldier to inquire after our welfare. The governor was a gentlemanly, wellinformed man, who entertained us most kindly when we called upon him, and offered us all the assistance that it was in his power to give us. Tete was suffering from drought also, so much so indeed that all trade had been suspended, and the masters, not having sufficient food for all their slaves, had allowed many of them to go where they pleased. Sheep and goats were not to be had at Tete, but the governor informed us that a Senhor Manoel, who had a farm about twenty miles below the town, would probably be able to supply our needs, and he gave us a letter of introduction to him.

Senhor Manoel did his best to meet our wants. We got from him sixty goats and fifty sheep, for which we gave him a bill for $f, 60$.

While with Senhor Manoel we heard that Chibisa had been shot by the man with whom he was at variance.

We returned to Tete on March I 2 th, our flock having been sent on the night before. Before we left, the governor made us a handsome present of goats, and offered to be responsible for sending to us at any future time any cattle we might need, if we would send over a messenger with a letter. Furthermore, he also offered to place at the disposal of the Mission any extent of territory, should our necessities compel us to leave the Shire, and our inclinations lead us to settle near Tete. I believe he made this offer in all kindness, but, rather than settle near to Tete, I felt we should prefer to leave the land; for Tete was the centre of the slave-trade, and both there and 
at Senhor Manoel's we had seen that slavery amongst the Portuguese in Africa was in its effects more horrible than I had thought possible.

Our return journey was wearisome in the extreme. Our. sheep and goats were a never-ending cause of anxiety to us, for we had to keep them from straying during the day, and sometimes to protect them from wild beasts during the night. I had not heard the roar of a lion in Africa until this journey. The first time I heard it we were safely sheltered in a village; the next time we were encamped in the bush, and then two lions prowled round and round our camp and made sleep impossible. They came quite close to us, for next morning we saw their footprints within thirty yards of where we had been lying. They did not leave us for several days, for the scent of our flock lured them on. I think that they must have followed us to the Shire, for soon after our return to the station we heard the roar of a lion for the first time in our neighbourhood.

In the homeward journey we all had fever. Thornton suffered severely; we had to carry Damanji in a litter, and two or three times, though I did not succumb to it, it made me stagger along the road like a drunken man. It was a most - painful journey, but, by God's help and dogged perseverance, we reached Mikaronko on the 27 th of March.

I had sent our guide on to the station two days before, with a letter apprising our brethren of our intention to wait at Mikaronko until they sent us medical comforts and more men, for of both we were sorely in need. I also sent on from Mikaronko an instalment of our flock, consisting of twelve of our sturdiest sheep and goats, for I was most anxious on Dickinson's account, feeling sure that the want of fresh meat for any length of time would probably be fatal to him.

About midday on the 28th, Blair arrived at Mikaronko with the requisite assistance. But he brought also a letter from Procter, the first sentence of which wrung from me an expression of grief that I could not repress. "Your letter," said he, "which I received last night, gave us the greatest possible pleasure, and I would I could offer in return as good news as that which it brought to us; but alas! I have to tell you, in 
the deepest grief, that our dear Dickinson, after a severe illness of eight days, has left us for the better home, where his will be the rest, we believe, which is granted to the faithful and devoted like himself."

Dickinson was dead! Dear, good, gentle-minded, lovinghearted, truly Christian man! While life lasts I shall never lose sense of the last affectionate pressure of his hand, never fail to see his last loving look as he said "Good-bye."

The remainder of Procter's letter, and another from Dr. Kirk, with the information Blair gave us, put us in possession of the state of things at the station since we had been away.

A few days after we left, Clark became worse, and Dickinson was so ill that a letter was sent down to the Pioneer asking for help. Dr. Livingstone and Dr. Kirk at once came off to their assistance, but Dickinson died half an hour before their arrival. Their aid however saved Clark's life, for though Dr. Livingstone was compelled to return to the ship, Dr. Kirk stayed for several days, and his letter spoke hopefully of his condition. Waller was much exhausted by fever, and sorely tried by constant watching and anxiety; and I resolved to get to the station as quickly as possible, for now that Blair had arrived with additional help, it seemed to me, and to Thornton also, that my presence at the station would be of more use than with the flock. So next day, after walking to Chinkokwe's, where the flock rested for the night, I took a man and a lad with me, and went ahead, and was at the station in less than twenty-four hours (March 3 oth), having been away just over the month. Thornton arrived two days later, having left the flock under the care of Blair, who came in with it on April 3 rd.

I was very glad to be back at the station again; but the sight of Dickinson's empty hut and the loss of his affectionate welcome made me sad. I visited his grave; it was close to that of Scudamore. Side by side, until the great awakening, lie the two friends. They were indeed "lovely and pleasant in their lives, and in their deaths they were not divided."

Clark seemed very broken in body, but he was bright in mind and spirit.

I found the station in a state of great excitement, for just 
before I came in, the Pioneer and the Lady Nyassa had arrived. Dr. Livingstone was looking careworn and aged, Dr. Kirk and Mr. C. Livingstone were suffering from dysentery.

The ships went to Matiti on April Ist, and Waller, who needed change, went up with them. But before the ships left we consulted upon future plans, and decided, when Waller returned, to move back to the hills. Mbame was dead, and we resolved to occupy his place. Our means were abundant, the country was quiet, for the Manganja had disappeared, and the only difference we should find in the highlands would be peace instead of war, and the Ajawa in occupation of the land instead of the Manganja. We had no fear of the Ajawa, and our people were joyful when they heard that we intended to live with them.

Thornton, after staying a day or two with us to rest, went up to the ships. He seemed to have recovered from fatigue and fever, and was very cheerful and happy. We expected to see him back again shortly, as he did not intend to stay with the ships ; but when Waller returned to us on April I4th, he said that dysentery and fever still prevailed on board the Pioneer, and that Thornton was ill. I did not think that his illness was more serious than usual, and so did not go up to see him; but on the evening of the 2 Ist, messengers came down to us from Dr. Livingstone with such a sad account of Thornton's health, that I resolved to go to Matiti next morning. Death, however, was beforehand with me. Indeed, before the messengers reached our station, Thornton, who I had learnt to love as a younger brother, had breathed his last. He was but twentyfive years of age, having come out to Africa with the expedition when he was only nineteen.

Our removal to the hills was deferred again and again. Dysentery attacked Procter; then I fell ill. That journey to Tete had tried me more than I at first knew; but when the reaction came, I was, so I was afterwards told, for some days in danger of a paralytic seizure.

The news that we received from the expedition was not cheering. The attempt to get the Lady Nyassa on to the Lake Nyassa was given up; and on the 19 th of May, Dr. Kirk, Mr. 
C. Livingstone, and four of the European sailors left for home. Clark went with them, for Dr. Kirk said that he could not stay longer with us without great danger to life or reason.

On the 27 th, Procter, thinking himself better, went with Waller, Adams, and a party of our men to choose the site for our station on the hills, but he overrated his strength; he broke down thoroughly exhausted before he could get to Mbame's, and the whole party returned next day.

I was still unable to make any exertion. I think we must both have died but for the care of Dr. Meller, who came down to us repeatedly from the ships.

Our people, however, were better off than they had been since they had been with us. They had corn in abundance in their houses, corn in their fields, and another crop or two in prospect ; quite enough to carry them on until the first fruits of the next year's harvest. It had been a hard struggle to get them into that position, but we thanked God that at last they were wealthy, as well as free, men. And they were proud of their position, and thankful to us for having made them what they were. A happier set of people could not be found in the land. No one who had seen them at that time working heartily, eating heartily, laughing heartily, and getting lusty and strong with good living, could have imagined what they had gone through. Now and then that period was brought painfully before us, in the person of some poor starving man or woman who came to us for help. We took charge of several such, and our people took to others, treating them kindly, and paying them liberally for any help that they were able to give them.

Procter still continued ill; and his only chance of life and future usefulness was to get to England as soon as he could; so it was agreed that he should go away with Dr. Meller, who was leaving the expedition on August Ist.

There was no help for it; though when he was gone, I alone of the clergy of the Mission would remain.

Towards the end of June we were daily expecting reinforcements from home; and our expectations were soon realised, for on June 26 th, Bishop Tozer and the Rev. Charles Alingtcin arrived at the station. 
Having heard from the Portuguese at Quilimane of the deaths of Scudamore and Dickinson, and knowing also that the expedition had been recalled, Bishop Tozer thought it inadvisable to bring up to the station all those that had come with him from England, and so had left Dr. Steere, Mr. Drayton (who was engaged to the Mission by Bishop Mackenzie), with three artisans, at Mazara, till he and Mr. Alington should make themselves acquainted with our position and circumstances.

In the consultations which followed, the older members of the Mission were unanimous in thinking that the Shire highlands were the best, and, under all the circumstances, the only position the Mission could occupy in that part of Africa. We did not think the attempt to hold them at all hopeless. Our influence amongst the surviving Manganja in the valley was great, the Ajawa would be friendly, we had stores of all kinds for eighteen months, war had ceased, and peace was not likely to be quickly disturbed; and with the aid of the people about us, a successful return, we thought, might be made to the hills.

On the other hand, there was a long and dangerous river journey, a land desolated by war and famine, sheep and goats not to be had nearer than Tete, Dr. Livingstone going out of the country, the original staff of the Mission reduced, by death and departures for home to save life, to Procter (who was only waiting for an opportunity to return), myself (for whom Dr. Meller said that a return home was necessary to arrest the effects which the climate was producing on my constitution), Waller, Adams, Blair, and Johnson.

No conclusion was really come to, but Bishop Tozer informed us that he had instructed Dr. Steere to go to Quilimane to obtain permission of the Governor to occupy Morumbala, if it were found suited for the purposes of the Mission, and it was deemed advisable not to return to the highlands.

Bishop Tozer left us on July 6th, taking with him Procter and Blair, the former to go home at once, the latter to return to us with final instructions. Before the Bishop left he visited Dr. Livingstone, who urged the Bishop not to remove the 
Mission. Mr. Alington remained at the station to supply Procter's place.

On July $\mathbf{i} 7$ th Dr. Meller left the expedition. We were greatly indebted to him, and for our own sakes deeply regretted his departure ; but for his sake we could not be sorry that he was leaving a land where he suffered almost constantly from fever.

On August 6th, a boat arrived from Mazara with a letter from Bishop Tozer to myself and Waller, informing us that he had decided to make the experiment of reorganising the Mission on Mount Morumbala, and giving instructions for the removal from Chibisa's. In another letter to myself he informed me that, considering the strongly expressed opinion of Dr. Meller upon my state of health, it was clearly my duty to return immediately to England. Johnson, at his own request, was to leave with me.

The removal to Morumbala involved, in the Bishop's opinion, the giving up of all our people, with the exception of the orphan boys. Had we desired to take them with us, these people would have refused to go, for with the exception of a few poor women and girls who were entirely dependent upon us, they had decided upon remaining where they were; for at Morumbala they would have been an isolated body in the midst of strangers and possible enemies. They were very sad when we told them that we were really going away; but prolonged depression of spirit is not natural to the Africans. They do not forget kindness, nor the people from whom they have received it, but they act literally upon the injunction : "Let us eat, drink, and be merry ;" and as they had both to eat and to drink in abundance, they soon, with a few exceptions, recovered from the depression of spirit which the news of our departure caused them. After I had said farewell words to them, and had returned to my hut, Jessiwiranga, "the excellent Jessiwiranga," as Bishop Mackenzie in one of his letters called her, and who used to work for and look after our little ones at Magomera, came to me with her babe-for she had married Sesimanja, one of our men-and, sitting down on the floor, began to cry, not loudly after the usual fashion of the natives, but quietly and sadly. Said she: "I do not like our English fathers going 
away from us. They said they would never forsake us. It is bad, very bad, to lose them. When they are gone, what will happen? The Chakundas will make slaves of us again, and then what will become of my babe?" And she hugged her little one as though to shield it. I comforted her as well as I could, but my heart was as sad as her own.

I left the station on August 7 th. The people assembled to bid us farewell, sorrowful enough for the moment. During the first hour or so of our journey the remnant of the Manganja that was left in the villages by the river, hearing the songs of the boatmen, came to the bank and shouted and waved their farewells. I knew most of them personally, for all, more or less, had in one way or another been brought under our influence, and it was owing to our protecting presence that they had been able to cultivate their gardens in security, and to eat the fruits thereof.

After we passed Mankokwe's, until we reached Malo, we did not see a single human being in the valley, all seemed to have perished. I visited the hut in which Bishop Mackenzie died. It had not been occupied since his death. I visited his grave. The place was so overgrown with rushes, grass, and bind-weed, that it was with great difficulty I could find the precise spot where he lay. As I stood by this holy ground his spirit seemed to be about me, and a glow of hope, the first I had felt for many days, relieved my sorrow. I was cast down still, but I no longer despaired. I felt then, and know it now, that the going forth of Bishop Mackenzie was not only not fruitless, but that it was the first step towards the conversion of the people to whom he was sent ; the first right movement towards the extermination of that iniquitous traffic, the slave-trade, which, for so long a time, kept these people in a state of terror and strife, and degraded them nearly to the condition of the brutes that perish.

We arrived at Morumbala on the afternoon of August irth, where we found that a good house had been built at the base of the mountain, and another much higher up, which were then occupied by Dr. Steere, Mr. Drayton, Blair, and two of the artisans that accompanied Bishop Tozer from England. We 
left Morumbala next morning, and went on till midnight, when we anchored ourselves to a sand island in the middle of the Zambesi.

On the 13 th, we fell in with Bishop Tozer, who was going up to Morumbala in a canoe.

On the I 6 th, I was at the Kongone, where I found Procter and Meller awaiting a ship which was daily expected. But after waiting in vain until October 23 rd, we started for Quilimane. Procter, who was much better in health, went by land; I and Meller, who was very ill, by the rivers in a canoe. From Quilimane we went to Mozambique in a trading yacht. Two days after our arrival at Mozambique the Ariel made hes appearance, and her commander, Captain Chapman, received us on board, and took us down to the Cape, where we arrived on December i 5 th.

While we were waiting at the coast we received much kindness from the Portuguese generally, and especially from Senhor Mesquita, the officer stationed at the Kongone, and Senhor José Nunes, of Quilimane; the generous hospitality of these two gentlemen saved us from much inconvenience and privation.

After I left the station Waller made final preparations for the removal to Morumbala. But it seemed to him a terrible thing to leave our people, for whom we had done and suffered so much, and who had proved themselves worthy of all that had been done for them, to the mercy of the first gang of merstealers that might come to Chibisa's; so after a consultation with Chimlolo, Damanji, and others, he resolved to send them up to the Ajawa chief Kepana, who was then in possession ot most of the highland districts with which we were acquainted, to invite him to the Mission station; for he thought that if Kepana would take our people under his protection their position would be more secure.

They were away several days, at the end of which they returned accompanied by Kepana and fifty of his principal men, most of whom were armed with guns.

Waller explained to them the motives which led us to interfere with the slave-dealers and the people of his own tribe at 
Chirumba and Chikala, and dweit upon the misery which came upon the Ajawa as well as the Manganja through the slavetrade.

Kepana, in reply, said he knew that the English were not his enemies, or the enemies of his people, that the results of the slave-trade were evil, and he would be glad to give it up, if we could show him what else to do.

Then Waller made him acquainted with the principal object he had in view in sending for him; upon which Kepana promised that he would look upon our people as the children of the English, that he would treat them as his own offspring, and that he would defend them as long as he could defend himself. He was, he said, master of the hill country, they might, therefore, come and go whenever they liked, and no harm should come to them; and when we came back, as he hoped we should do soon, we should see that he had kept his word.

Kepana stayed several days at the station, and visited the ships at Matiti before he returned to the hills.

Waller also managed to bring about a reconciliation between him and the Makololo; for they had been at variance, he having received some injury from them.

The conduct of this man proved beyond question that, had other things been favourable, we might have returned to the hills without fear of molestation from the Ajawa, that they were indeed quite willing to receive us as friends.

There was another subject which gave Waller much anxiety. Amongst our people were some women and girls who were, as I have said, entirely dependent on us, and he could not find it in his heart to forsake them; so he gave up the position he held in the Mission, and on his own responsibility took them with him to Morumbala, where he supported them until he was able to carry them down to Cape Town, where he found homes for them. 


\section{CHAPTER IX.}

A FTER a few months' residence on Mount Morumbala, A. Bishop Tozer, not considering it expedient to make any further attempt to re-occupy the Shire highlands, determined to leave that part of the country altogether, and to seek some other base of operations for the Mission. Early in 1864, therefore, he and the other members of the Mission left the Zambesi for Cape Town. After staying there some weeks, and discussing with friends the merits and claims of the different mission-fields that were open to him in Central Africa, the Bishop resolved to make Zanzibar his head-quarters for ultimately reaching the tribes of the interior; and an opportunity occurring of obtaining a passage in a man-of-war, he started for that place accompanied by Dr. Steere. As there was no immediate need for their services, the rest of the Mission party returned to England.

It may be as well to state here that when he left Morumbala, Bishop Tozer was not able to take the orphan boys that had been brought down from Chibisa's with him, so he wrote to Dr. Livingstone and asked him to take them down to the sea in the Pioneer, leaving them in the meantime in the care of Mr. Waller. The latter remained in Morumbala until the Pioneer arrived, and succeeded in getting them, with the exception of Wekotani and Juma, whom Livingstone took into his service, down to Cape Town, where he found suitable homes for them.

The reasons which induced Bishop Tozer to make Zanzibar the head-quarters of the Mission were:-

I. Because it is the capital of Eastern Africa, and the great centre of trade for the whole coast and the vast territory which lies behind it. 
2. Because of its political importance, its ruler having authority along the coast from Cape Guardafui to Cape Delgado, and his power extending far into the interior.

3. Because the language of Zanzibar-the Swahili-being the official and the trade language, is evierywhere more or less understood; so that if you have mastered it you will find in every tribe within reach of Zanzibar some who can act as interpreters, and who can therefore make you acquainted with their own languages.

The island of Zanzibar lies 500 miles to the north of the Zambesi, and is about twenty miles from the mainland. Its length is 48.25 geographical miles from the northern to the southern extremity, and its breadth is eighteen miles. Its greatest elevations are about 500 feet above the level of the sea.

The appearance of the island from the sea is that of coralline islands generally; a graceful, wavy outline of softly rounded ground, and a surface of ochre-coloured soil, thickly clothed with foliage alternating between the liveliest leek-green and the most sombre laurel, the only variation that vegetation seems subject to in this land of perpetual verdure.

The town of Zanzibar is built on a sandy peninsula, triangular in shape, which is connected with the island by an isthmus some 300 yards wide. Seaward the town shows a long front of white square houses built of stone, and presents an attractive appearance. In the town itself there are no streets practicable for wheeled carriages, very few being more than ten or twelve feet wide, and in many parts of the town there are no proper streets at all. The greater number of houses are built only of "mud and stud" thatched with the cocoa-nut leaf. These houses are divided by internal partitions into a number of small rooms, but have no light except from the door. There are some chief thoroughfares, and some streets of shops, which are merely small stone houses with the front of the bottom storey taken out, and are therefore quite open to the street.

There are very few open spaces in Zanzibar; the largest is a square walled enclosure with a few round, tub-shaped towers, 
called the great market. Fiere, between nine and twelve in the forenoon, oranges, cocoa-nuts, sugar-cane, bananas, sweet potatoes, pine-apples, cassava root, and mangoes are brought in on men's heads in great quantities. The next largest open space was, when Bishop Tozer first arrived at Zanzibar, the slave market.

The harbour of Zanzibar frequently contains more than a hundred large native vessels lying packed together like ships in a dock, five or six men-of-war belonging to the Sultan, and often eight or ten European ships taking in their cargoes of cloves (the principal production of the island), gum copal, ivory, hides, red pepper, cocoa-nut oil, orchilla weed, and so forth.

The climate of Zanzibar throughout the year is scarcely marked by any difference of heat, the thermometer seldom standing fa: from $80^{\circ}$ in the house; and there is but a trifling difference between the length of the longest and the shortest day, the sun always rising and setting within twenty minutes of six o'clock. Storms are rare, and a high wind seldom prevails for more than half an hour at a time. There are two rainy seasons - the greater, which usually lasts from March to June; and the less, in November. After the greater rains comes the cold season of June and July, when the thermometer sometimes goes down to $75^{\circ}$, and everybody shivers.

The population of the island of Zanzibar has been variously estimated at from I 50,000 to 200,000 souls, of whom the greater number live in the capital. The basis of the population consists of the Swahili, a mixed race of Arabs and Africans.

The history of Zanzibar, and of the whole of the coast north of it, is merely that of a succession of Arab conquests. One tribe comes down and conquers the natives, and then sinks into an effete state by mixing with them and adopting their customs. Then another tribe comes, conquers, intermarries, loses its energy, and makes way for a fresh race of conquerors. The effect of all this is a race and language in which the Arabic and African elements are thoroughly mingled.

The father of the present Sultan partly inherited, partly conquered the coast, he being also ruler of Muscat, which lies 
near to the mouth of the Persian Gulf. The great men are now chiefly Arabs from Muscat and Oman. The merchants and traders, even to the smallest shopkeepers, are Indians from Cutch and Bombay; they are either Mohammedans who settle in Zanzibar, or heathens, known as Banyans, who never bring their wives with them, and only come for a time to trade and make money. The lowest class are the natives from the interior, who are either slaves or free men. It is difficult to tell who are slaves and who are not, as it is very common for slaves to pay their masters two dollars a month, and shift for themselves. The lowest pay for work which does not require much thought is eight pice, or threepence, a day; this is about equal to two dollars a month, which will just feed and clothe a man, if he eat nothing but cassava root and a relish of salt shark, and makes two yards of unbleached calico supply him with raiment for half a year.

Skilled workmen get about a shilling a day, which, considering the relative cost of food and clothing, is very good wages.

Besides the people already named, there are the representatives of many other races. Arabs of other tribes than the Muscat, particularly the people of Sheher, who do all the work that requires energy and strength; people from the Comoro Islands, and Madagascar; Indians of many races; Turks, Persians, Belochees, and Abyssinians; a few Europeans, and some Americans. Amongst the women-slaves are Georgians, Circassians, and Greeks.

The better class of the Zanzibar people lead very idle lives. The usual course of a day for a man is something like this : Soon after daylight he will wake, and if he be at all devout, will go through his morning devotions; he then lies or sits on his bed (which is a light wooden frame laced with thin cocoanut cord, and covered with a mat) until about ten or eleven o'clock, when he dresses and goes out. Every house is furnished with a seat, called a baraza, outside the door; here the master spreads a mat, and awaits callers. When any such appear, the health is mutually inquired after, then the news, and this goes on until noon has arrived, when food is ready, consisting generally of rice and fish cooked with curry, or for 
the richest classes, fowl, sweetmeats, and fruit. After these are discussed and some water drunk, they wash their hands, and then lie down and have a doze. Between three and four the man dresses himself with care, and if he be at all a dandy, scents himself, and taking his stick or his rosary in his hand, goes out to make the round of his friends. Those who do not go out sit on their own barazas, and generally have a supply of coffee ready for all comers. About sunset the man goes home again, performs his sunset prayers, and has another meal of the same kind as before, he and those with him dipping with their hands out of the common dish.

The lives of the women are as idle as those of the men; a little cooking and sweetmeat-making is their only recognised employment; needlework is man's work, and only a few women know how to do it. To lie on a bed and be fanned by a couple of slave girls is the usual way of passing the time by the richer women. Of course the lower classes of women work for their living, as do the lower classes of men. Some plait the various coloured mats which serve for bedding, and others carry stones and lime, and, chief of all their employments, water.

In the town of Zanzibar the water is brackish, and women go out into the country two, three, or more miles to fetch in water that is sweeter.

The ways that lead out of the town are generally full of women going and coming with water jars on their heads and Katas, which are cocoa-nut shells at the end of a long stick to scoop up the water out of the pits which serve as wells, in their hands.

Such is Zanzibar, and such are its inhabitants.

Bishop Tozer and Dr. Steere arrived at Zanzibar in August I864, and were most kindly welcomed by Colonel Playfair, the English Consul, who took them into his own house. In the course of a few days, however, through the instrumentality of Colonel Playfair, the Bishop was able to make an arrangement with the Sultan for the occupation of a large house facing the sea, to be devoted permanently to the purposes of the Mission.

Zanzibar, at this time, was the seat of a vast unblushing trade in human beings. For many years there had been a treaty 
between the British Government and the Sultan of Zanzibar forbidding the export of slaves to foreign countries, and English men-of-war cruised on the coast to intercept slaving vessels ; but the slave-trade flourished, nevertheless. Writing of this period, Dr. Steere said :-

"I hope one may never see again such sights as one used to see almost daily when we first landed in Zanzibar-the miserable remains of the great slave caravans from the interior, brought by sea to Zanzibar, packed so closely that they could scarcely move, and allowed nothing of food on the voyage but a few handfuls of raw rice passed round to be nibbled at. It is said, sometimes, that our efforts to stop the slave traffic have increased the sufferings of the slaves during their transit, but it was simply impossible to increase the misery of this open and unrestrained traffic between Kilwa and Zanzibar. Even as it was, the least delay caused a large proportion of deaths, and the parties of slaves that were led from the customhouse to their owners' houses presented every form of emaciation and disease, till it seemed impossible that they could support themselves, if only for a few minutes longer. There were evers some who were left lying at the custom-house, because it was doubted whether they could recover at all, and the traders would not pay the duties till they knew. Beyond even this, we have found some yet alive, left upon the beach by the sea, into which they had been thrown as the dhow neared the harbour, because they were already past all hope of recovery.

"The Arab is almost always an indifferent, though rarely a cruel master, and the waste of and recklessness about human life, in every part of the transit of slaves from their homes in the interior to their Arab masters' houses, would have seemed wholly incredible, had we not seen with our own eyes so much, and found the testimony of all who have seen anything, agreeing so completely."

The usual course of the trader when he wished to get his human commodity beyond the Zanzibar territory, was to take a pass to some place within the Sultan's own dominions, pay the customs duties (and this tax on slaves formed a considerable portion of the Sultan's income), make presents to the Sultan's 
favourites to prevent awkward inquiries; and then using the pass as long as it was of any use, make his way to Arabia. But sometimes the trader endeavoured to evade the customs, and sometimes instead of buying slaves he stole them, and then it not unfrequently happened that the Sultan would seize and burn his vessel, take the slaves and distribute them as presents amongst his friends. An incident of this kind happened just as Bishop Tozer and Dr. Steere arrived at Zanzibar, when the Consul suggested to the Sultan that it would be a graceful act to give some of the boys into the charge of the Bishop, who had just been to pay him a complimentary visit, and the Sultan gave him five. With these boys Bishop 'Tozer commenced afresh the attempt to bring the Gospel to the regions of Central Africa. Realising keenly the difficulties in the way of a conversion of the natives through the agency of European missionaries only, he resolved from the native materials he had in hand, and from others that might come to him, to raise up a native ministry, and to entrust to it, in the main, the work of extending Christ's kingdom amongst the tribes of the interior. Until additional aid came to him from England the Bishop devoted himself to the education of these boys with that object in view; and Dr. Steere, being more than most men qualified for that branch of the work, gave especial attention to the study of the Swahili and other languages.

In a speech delivered at Oxford some years afterwards, the latter, in speaking of this period of the history of the Mission, says :-

"Now if you can imagine yourself standing opposite to five little black boys, with no clothing save the narrowest possible strip of calico round their middles, with their hands clasped round their necks, looking up into your face with an expression of utter apprehension that something more dreadful than ever they had experienced would surely come upon them, now that they had fallen into the hands of the dreaded white men, you will feel our work somewhat as we felt it. And then, how are you to speak, or they to answer? You have not one word in common. Yet these are the missionaries of the future. When any one tells his friends in England, that our plan is to educate native mission- 
aries, people say, it is a very good plan, and no doubt in a few years we shall see great results. But when you come to begin with the actual pupils, you will see that it is not a work of a few years, but rather, as life is in Africa, of several lifetimes. So having no other way at hand, we began to teach them the English alphabet, and to read our common school reading-cards. We found them sharp enough, and soon began to make way towards a mutual understanding. Then we added others from vessels taken by the English men-of-war, and a few brought to us by their friends. Our plan was not to bring in such numbers as that we might be overwhelmed by a mass of heathenism, but to try and give a Christian tone to our first scholars, and then to bring in a few, time after time, so that they might catch the rising spirit. Thus our school grew on, and soon we were joined by some lady helpers, and a girls' school was formed after the same manner.

"It was not long before even the natives perceived that our boys had an air and a bearing such as their old companions never had. It was their Christianity beginning even so soon to show itself, as sound religion must, in their ordinary speech and bearing. We had taught our children that white men might sometimes be trusted. They have told us since that their impression was, the first night they slept in the house, that they were meant to be eaten."

In the extract from Dr. Steere's speech, the results of a long time of work are given in a few words; but the details of the way in which the school grew in numbers, and of the work done in it, are very interesting,

On the evening of May 14 th, 1865 , information was received that a dhow was about to sail with a large number of slaves on board. A British man-of-war was in the harbour, and two boats were despatched from her to look after this dhow. One boat made for the open sea, the other for the place on the shore where the dhow had been seen at anchor not long before. The dhow had left her anchorage, but she was sighted at no great distance off; and both boats drew up to her at the same time, and their crews boarded her. A desperate hand-to-hand fight ensued for about ten minutes, 
and then the Arabs gave way. The victory, however, was not gained without loss; the coxswain of one of the boats was killed, and three officers and eight men were seriously wounded.

Besides about fifty Arabs, there were nearly three hundred slaves on board the dhow; the latter were found packed close together like logs of wood, in a place not three feet high.

Next day, Captain Bowden, the commander of the man-ofwar, called on the Bishop, and told him that if he would go with him to the Seychelles, where the slaves were to be liberated, he should have some of the children to train up in his school. The Bishop gladly consented, and, to his great surprise, when he reached Seychelles he found that his sister had just arrived there with a friend, Miss A. Jones, and Mr. Harry Goodwin, a layman, on their way to join the mission at Zanzibar.

Writing upon what followed, Miss Tozer says :-

"The slaves were to come on shore at once, and Captain Bowden asked us to walk down to another pier a little farther on, to see the first 'cargo' landed. I went with him and the Bishop, and saw the boat come ashore with its dusky load. How can I describe that landing! Tenderly lifting the tiny baby children out with rough kindly words, the sailors set them down, and they squatted patiently on the ground. Some of them were no more than three years old, but the most about six. Then there came a poor little girl that had been wounded in the battle, who was lifted out so carefully in a carpet by the sailors. Then I saw the Bishop handing out a mother and babe, the great tearful eyes of the mother looking wildly round as she clutched her child close. The sight of those fifty little creatures squatting round so patiently was quite touching, and I think you would have done as I did, sat down and cried. It was the first realisation of slavery, the first coming face to face with it.

"The next day, Ascension Day, after church, the Bishop took me to choose my own children, as we were to have the first selection. It was a difficult thing to do, for one longed to have them all; but I was only to have five boys and nine 
girls. So we divided them as well as we could into tribes, and chose the boys first and then the girls. They are all very happy, and have plenty to eat, and the Bishop and I go down and see them every day, and he talks to them. They will live where they are (in the prison) till we go home, and then my fourteen little ones will go with us.

"On Wednesday morning, June 2oth, I came in sight of my new home (at Zanzibar). We had hardly anchored before the Consul and Dr. Steere came on board to welcome us. There were such kind partings, and the children were fondled and loaded with presents.

"When we arrived at the Mission house, little black faces peered anxiously from a room, and as soon as the Bishop called, 'Joni watoti wangu' (come, my children), down the nine little fellows came, and seizing the Bishop's hands, kissed them ; and then said to me, 'Good morning, ma'am.' They call me the Bibi, which, I believe, really means grandmother, and I accept the name gladly. The sun was low, and we had but little time to see our palace, as it is called here, but we all went round and admired the clever arrangements that had been made by Dr. Steere, and Harry Goodwin (who left the Seychelles before the Bishop and Miss Tozer). They had built walls, pulled down walls, opened doors, shut windows, and so made room for us all.

"One side of the corridor is allotted to the girls and me and Miss Jones ; the boys and Harry Goodwin have their rooms on the other side; in the room where we sit to work and write we have our classes. At this moment seven girls are seated hemming some handkerchiefs. The boys, having finished their lessons, are gone to bathe with Dr. Steere.

"The nine boys are perfect little gentlemen, having nice manners and being full of intelligence. They speak a little English and understand all you say. Yesterday I gave them a singing lesson in the chapel (a large room in the house which had been fitted up for worship); they sang the Glorias and two hymns in English very nicely, and their conduct is bevond all praise.

"They are delighted with the fourteen new friends we brought 
them; and ever since we came I have watched in vain for the smallest quarrel,- they never disagree, and share everything that is given them. I suppose they will be naughty sometimes, like others, but so far we have seen nothing of temper, though they are full of spirits."

[The new-comers suffered for some time from the effects of their previous hardships and privations.]

"August 23rd.- The Bishop is at his pleasant work, the making of a font for to-morrow's delightful service. Our nine little lads of the first set are to be baptized at 6.30 A.M., St. Bartholomew's Feast. The font is a large new metal basin, set in a box draped in white and covered with flowers. This stands on a pedestal covered with a scarlet cloth gold-bordered. The children are taking a most intelligent part in all that is being done, and I have been for days reading and then explaining to them the Baptismal Service.

"August 24th.-This day, Feast of St. Bartholomew, so long looked forward to, dawned at last. At five o'clock it was a perfect calm, the beginning of one of those tropical still days that portend a change of the monsoon ; but the sunrise colouring was lovely. At half-past five the house was up; and I heard the Bishop in every part in turn.

"I must describe the chapel a little. There were four bouquets of flowers over the altar, and boughs of mango in all the recesses. The west end was cleared of chairs, and the white dais took up nearly a third of the width. On either side, in their little low chairs, sat at the beginning of the service the nine boys that were to be baptized; the five others were in their places at the east end."

The Bishop, writing on the same subject, says :- "It is a day much to be remembered by all Central African Mission sympathisers. We know well, from past experience, how to sympathise in sorrow, and now we have, through God's great and undeserved mercy, to share in the great joy which yesterday's early service has brought us.

"The dear little band of native Christians are all that I could wish, and their conduct and behaviour at the font was strikingly devout." 
The arrival of the Seychelles party (eighteen in all) made the need of further accommodation felt; and to supply more house-room the Bishop resolved to build an industrial school for the boys, on a small estate called Kiungani, two miles from the town, which he had purchased with the first remittances from the Wells Tozer Fund - a fund that was started by the then present and former students of Wells Theological College, where the Bishop studied for some time after leaving Oxford.

On August 5th, the Bishop reports that he had been able to increase the property of the Mission still more, by the purchase of a large and valuable plot of land, enclosed by stone walls at the back, and open to the sea.

"It is," says he, "the property next to this, and possesses a long sea frontage, which is becoming every year of more and more value. So soon as we can obtain two or three other little pieces of land which intervene between our new purchase and the small stone house which I told you in my last we had bought, we shall have a fine open site, in the extreme end of the promontory on which the town stands, capable of being used for almost any number of buildings which may be required hereafter for the purposes of the Mission.

"The house which we bought was no sooner delivered over to us by its former proprietor, than we had to occupy it as an hospital-one of our little girls having caught smallpox, which is very prevalent in the place. By sending her at once away from the others, we have kept free from further sickness, and I cannot say how thankful I am that we are able to avail ourselves so seasonably of the separate treatment."

Of the girls that were especially entrusted to her care, Miss Jones wrote the following description:-

"Faiida is about twelve or thirteen, unfortunately too old to improve much in manners. She has too much of the lazy slave already ingrained in her composition. She is not at all bad-looking for a negress, and belongs to a tribe settled nearly half-way across the continent of Africa. She has a very affectionate disposition, and I can thoroughly depend upon her to do any nursing for her sick companions. I wish she were two 
years younger, as she certainly is not over wise, and we have all the difficulties of language to contend with.

"Anana is, I imagine, rather younger than Faiida, and a troublesome girl, but her faults are more easily dealt with than those of her neighbours. She is not a pleasant-looking girl, and was away two months with smallpox; so, possibly, that is the reason why she remains so long untamed. She has been a slave at Zanzibar, is impertinent and noisy ; but being tolerably willing, and very strong, I hope she will some day make a good useful woman.

"Kadumhili is my maid, and being the best tempered and most with me, it is sometimes difficult not to show favouritism. She has rather a fat little short-nosed terrier sort of face, that would be called Pincher about an English farmhouse. Always ready to laugh, quicker at speaking English than most of them, and understands me well enough to act as my interpreter to others. She writes nicely, and really is the pleasantestmannered of all the children; but forgets her household duties too frequently, - to prevent my spoiling her, I suppose.

"Sukajua is Miss Tozer's maid. She is not a stupid child over many things, but she either cannot or will not learn her letters, and understands very little English. She is a great mimic. The manners of myself and the whole household are taken off by her. She gives me very little trouble now. At first she used to talk much and loudly; now she only tears her clothes, and is quite unable to repair them. Miss Tozer speaks of her as becoming a very handy little waiting-maid.

"Kisa, - this child is so unfortunately fat, I really don't know whether it makes her stupid or sad. "She is a good-tempered girl, of about ten or eleven, and does all I tell her to do very well ; is fond of needlework, and works much faster than the others; does not yet know her letters, but learns anything viva voce as well as any of them. She is stolid in manner and appearance, her voice is seldom heard in the rabble; and although she can understand me, she is very shy of speaking English, and especially dislikes notice. She is not at all a selfish child.

"Alliango is a bright little thing of eight or nine, much dis- 
figured by having her nose and ears pierced. She can always make me understand, either by word or action, all that is going on either out of doors or in. She is a pleasant little child, but becomes sulky if punished. Her manners are much more like those of an agricultural labourer's child in England than any of the others. She has a sort of motherly eldest-daughter's way of cleaning up the table after dinner that is quite refreshing to see with her dark skin, and she has the bump of order, and also of keeping her companions in order.

"Chidoge is one of that lively sort of children whom one sees in any school; she is always skipping about, and breaking something or knocking something over, and without being wilfully wicked, is always falling under the ban of the law. When punished, she goes off to weep in the most out-of-the-way places, and being very thin, with a small head, can creep about like a monkey. I found her the other day seated on the outer ledge of a window, some thirty feet above the ground; the ledge was some eight or nine inches wide, and she had crept through some iron bars, certainly not more than seven inches apart, to get upon it. She enlivens her duties by a perpetual but not melodious song.

"Satia is often quarrelling with her playfellows, and speaks in a loud voice to get commiseration from her governess, which she frequently fails to do. However, she is but a wee thing, and has not shed her baby teeth yet. Her needlework is charming, her writing will be fair some day. She does not speak Swahili plainly, and her English of course is very small and incorrect. $F$ at the beginning of a word she regularly converts into $P$, and vice versâ.

"Gehinja, this is my poor little invalid. Always ailing, poor little thing. One cannot help liking her for her patience, as she never complains when ill; but as she recovers a little, she shows evidence of a troublesome temper. I think that she tries to get on with everything that others do; but she is so weakly, she can seldom sit still for two hours in the morning, and again, for the same time in the afternoon-so I often have to send her away to lie down; but though the poor child is so sickly and full of misfortunes, I have the satisfaction of feeling, 
that if she live she will, perchance, in school, be the longest under instruction.

"This is a very good house-the best, I think, in the town; it is a pity the navy have the lower part and the courtyard reserved for a coal store. It would be pleasant to have more sitting-rooms, instead of sitting so much in the corridors; in fact, we are always there excepting for meals-keep school, receive visitors, do needlework, and wash the children."

Mr. Harry Goodwin, writing in January I866, says :- "It did not seem a bit like Christmas this year to me. The weather has been getting warmer all through December until now ; so I think we may consider this to be the summer. It affects us all, more or less. Miss Tozer perhaps suffers from it most. The Bishop is well. Dr. Steere has gone to a place called Kokatoni, a part of Zanzibar about twenty-five miles from the town, with Captain —, who has a large sugar plantation there.

"January 3 Ist. Dr. Livingstone arrived here a day or two ago in a small steamer from Bombay. He has not called at the house yet.

"I have seen scarcely any lightning nor heard much thunder since I came here, but last night for the first time we had a fearful storm ; it seemed to be one blaze of lightning all night, and one continual growling thunder; and the rain was just like standing under a waterfall; but it rains so very seldom that I have only once used my waterproof coat.

"The Bishop is very hospitable, and often has the dignitaries of Zanzibar to dinner, such as the French and German Consuls ; and we are great friends with all the captains and officers of the ships on this station, who come to tea in small parties of ten, upsetting all Miss Tozer's housekeeping arrangements."

Other visitors were not infrequent. Arabs of high degree were continually calling to make the acquaintance of the Bishop, and to hear what he had to say. On one occasion, at this period, a Sheik, who lived in one of the mosques day and night, a man of great reputation as a teacher of the Koran, accompanied by twelve other men, called, and on being asked why he left the seclusion of the mosque, replied, "To see the 
Uskoff (Bishop), and to hear the good words all say he lets fall."

Mr. Goodwin's attempt to teach the boys the game of cricket was a failure-they were afraid of the ball; but the game of rounders suited them better, and they soon played it capitally. Speaking of them, he says :- "They are very intelligent and quick at learning, and some have made great progress in drawing, in which I give them a lesson three times a week. One is almost as tall as I am, and very good-looking, quite different from the general race of Africans. The boys make the beds, sweep the house up, and wash everything in the crockery line; so we are not troubled with any dark maids, except those that bring water in from the country."

These narratives by the various members of the Mission describe its position and work during the first eighteen months at Zanzibar. The difficulties and trials, it will be seen, at Zanzibar, were different from those that the Mission had to encounter on the Shire highlands and in the Shire valley; but the climate was not found to be better, and its effects were not less serious. The first to feel this severely was the Bishop himself, whose state of health eventually gave so much cause for anxiety, that Dr. Seward, the medical officer attached to the Consulate, ordered his return to England, for the benefit both of the voyage and of complete rest and change: and in order to give the Bishop the opportunity of visiting England, the Rev. C. A. Alington, who accompanied him to Chibisa's, had arranged to go out to Zanzibar for a time.

The Bishop left Zanzibar on September 2oth, I866, and for the benefit of a long sea voyage made the passage home by way of the Cape. Soon after his departure, Miss Tozer, who suffered scarcely less than her brother from the climate, sailed for the Seychelles in H.M.S. Lyra, and came to England by the overland route. 


\section{C.HAPTER X.}

$\mathrm{O}^{\mathrm{N}}$

September 6th, 1866, Bishop Tozer wrote:-“"The present establishment at Zanzibar is but a stepping-stone to the central tribes, and can never be considered as the 'Ultima Thule' of our hopes and plans, unless we forego the very object for which the Mission was inaugurated. For my part, I shall never rest satisfied, should God spare my life, until I find myself, in some sense, the Bishop of the 'tribes around Nyassa, and the adjoining country in Africa,' according to the terms of the Royal Licence, under which I was consecrated. How best to carry out this work is the problem which we have to solve."

Upon the arrival of the Rev. C. A. Alington, and Mr. and Mrs. Drayton, who had been expected before the departure of the Bishop, the ordinary work of the Mission was carried on as usual, and after a time an effort was made towards solving the problem to which the Bishop alludes.

The districts of the mainland most accessible from Zanzibar, and recommended as suitable for the establishment of mission stations, are the Usambara country, about fifty miles from the coast, the Jagga country, about 150 miles inland, and the Lake Nyassa country.

In the natural order of events it seemed that, other things being favourable, the Usambara country should be first occupied, and Mr. Alington determined to make an expedition to it with that object in view.

The Rev. J. P. Farler, whose work in Usambara will be spoken of hereafter, in a paper read before the Royal Geographical Society, thus describes this country:- "Usambara has been called the Switzerland of Africa. It forms a link 
in the east-coast range which extends from Abyssinia to Natal. Speaking roughly, it lies between $4^{\circ} 20^{\prime}$ and $5^{\circ} 25^{\prime}$ lat. S., and $38^{\circ} 20^{\prime}$ and $39^{\circ}$ ro' long. E. The mountains form four detached lines running due north and south, rising in the higher peaks to about 6000 feet above the sea-level. They are separated from each other by elevated valleys, table-lands, and terraces. The whole range was evidently thrown up by volcanic action, and consists of granite mixed with spar, with sandstone in the lower spurs containing plumbago. As a rule, the mountains are covered with jungle to their summits, but in some of the higher peaks the granite is exposed in the shape of massive blocks which take the most fantastic forms. Some of the hill-tops are without trees, and then they are covered with a soft elastic turf. The scenery is beautiful and varied; now soft valleys and hill-sides with hanging woods, then wild ravines with precipitous cliffs of bare granite. The country is well watered; every mountain has its spring, and every valley its streamlet. It is divided into four districts, inhabited by people who call themselves by different names. First, the Wakalindi, living upon the fourth line of mountains, and on the northern spurs of the second and third ranges; next the Wasambara, inhabiting the first three lines of mountains; then the Wabondeis, which means 'people of the valley,' or lowlanders, living upon the lower spurs of the eastern side of the first range, and in the plain to the north of the Mkaramu Mountains. On the banks of the Luvu, and in the valleys between the ranges, the people are mostly Wazegua settlers."

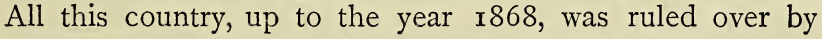
Kimweri, who was fifth in descent from Mkande, who founded the dynasty. Mkande was said to be a great hunter who lived in a country north of Chaga. In one of his hunting expeditions he came down to Usambara, and there killed a huge buffalo. The Wasambara were so struck by his prowess in the chase, that they invited him to be their king. He consented, and at once commenced to organise his new kingdom, and then brought into subjection the Wazegua, who inhabited the plains and valleys north of the Luvu, the Wabondeis, and the Wambugu. The Wakalindi claimed descent from him, and 
continued to be the ruling caste until old Kimweri's death. They constantly increased their numbers by adopting favourite slaves, who thus became Wakalindi; and it is not difficult to understand how they became a numerous tribe in five generations, when we are told that Kimweri had a hundred sons and an unknown number of daughters.

Usambara is drained by four rivers : the Zigi, the Mkulumuzi, the Ukumbini, and the Luari. None of these rivers are navigable, and the Zigi has rapids about fifteen miles from its mouth.

The port most commonly used by travellers from Zanzibar is Morongo, a town on Tangata Bay, and about sixty-five miles north-west of Zanzibar town.

For two or three miles the path to the highlands lies through well-cultivated farms, and then cultivation ceases and the wilderness begins. This is a rolling plain of coarse grass and thick bush, with here and there a thicket or a fine clump of trees. In some parts the soil is sandy, but in others it is a rich vegetable loam. In the bottom there are beds of whitish clay, and quartz is found in the dry water-courses. In this wilderness there is a great variety of trees; euphorbias, fan palms, and mimosa thorns are seen everywhere, and occasionally baobabs, tamarind-trees, and clusters of the borassus palm. There are various kinds of animals,-antelopes, from the kurunga, the size of a cow, to the funu, the size of a small goat ; lions, leopards, hyænas, big apes, and small monkeys. As the ascent is made the country changes its character, and is in its principal features not unlike that leading up to the Shire highlands.

The soil throughout Usambara is a red disintegrated clay upon a granite and sandstone foundation, and covered with a rich vegetable loam. The bottoms of the valleys contain beds of alluvial clay. A more fertile soil it would probably be difficult to find.

The flora of Usambara is extensive. In the forests are ebony, copal, teak, acacia, india-rubber tree, the orchilla weed, the betel-pepper climber, prickly smilax, several varieties of the strychnos, and many other trees producing valuable wood.

'The Wasambara are Semitic rather than negro in their type, 
having high foreheads, while the prognathous jaw and spur heel are both wanting. In form and figure they are perfect. They average $5 \mathrm{ft}$. 7 in. in height, and are strong though not robust. They vary in colour from a light brown to a deep black, that is soft and shining like satin. They have good perceptive faculties, and are not long in discovering the character of the person with whom they have to deal. They are shrewd in the common affairs of daily life, and hospitable. They are brave under a good leader, and they show love for their parents, and respect for old age.

For this country Mr. Alington left Zanzibar on August I $3^{\text {th, }}$ I867, accompanied by Vincent M'Kono, one of the mission boys, and a man named Khatibu, a Swahili from the coast. He was much delayed at Tangata, and did not succeed in getting away until September I8th, when he crossed the bay in a canoe, and struck inland at once, plodding away for some time in the dark. "When the morning broke," says he, "I found myself in a very uninteresting swampy part. About 8 A.M. we reached a village of the Wazegua. We had to wait here a while for Khatibu, who had stayed behind to look after a missing bearer. When he arrived it was decided that we should rest here for the night; so that our first day's march was a short one. Our quarters were bad enough. I lay down in the hut, but as for getting any sleep, that was out of the question: so I read through the night, and glad enough I was to turn out about 4.30 and make my coffee. We were advised not to start very early on account of the lions-the old story. In the after part of the day we began to ascend, and from that time all our work was very hard. The burdens soon told heavily upon the coast men. We passed a town called Umba, where was an officer of a chief named Mjata, who claims to be independent. Khatibu thought that a doti (a present) should be given to him, which we did accordingly. Soon after leaving Umba we took what proved to be a wrong road, the Shambara men having gone on before, and their head man sending us by a way that led through Mjata's villages; Khatibu was in a great state about this. However, we reached M'zungu's without any mishaps before sun-down. M'zungu is 
an uncle of Kimweri, and we found him a civil old gentleman, quite superior to the usual run of (native) Sultans. He made us a present of some rice and chickens, and had of course a return present.

"On the 2 oth, we had a very heavy day's toil, over a country not made for European travel. The bamboo brakes in the valleys were very trying to the bearers, and the steep mountainsides were too much for us all. It was not till 8 P.M. that we tottered into M'sasa's village. We had started before sunrise, and I had taken no food but some bites of biscuits and a few bananas. I was thoroughly tired out, as indeed all my party were. One of the bearers was so ill that I had to replace him. I believe the Shambara people led us this rough road because of the abundance of bananas in the deserted Shambas. It was astonishing to see the quantities they brought in and managed to eat. The Wazegua harried this part of the country some years ago, and it has not been repeopled The air on the hills was delicious, and now and then I got a fine view. We stayed all next day at this place. The rain came on, and the roads were said to be too slippery for the men to travel. So there was nothing for it but to wait again. Rest I could have, to be sure, but no refreshment in a hut full of smoke, and crowded with not the most pleasant of companions.

"On Monday the $23 \mathrm{~d}$, we were off by sunrise, and crept down the opposite side of the hill. It was hard labour crossing the different spurs of the mountains, and we made but little way. I was much provoked at being led by this path, which was so rough and impracticable for the porters that it could never do for a regular route; I do not think even a donkey could be got over it. About 3 P.M. we reached the edge of the ridge, and had a noble view over a broad valley. It is a fine fertile country, and would support a large population. We descended into the valley and reached Chruruwi in the evening.

"Next morning the Shambara men brought back their cloth, and declared they would proceed no further. I said nothing, but left the matter in Khatibu's hands. Away they went; but Khatibu must have used his tongue effectually, for in a short time the rebels returned. It was nothing but a ruse. After a 
great dispute it had been agreed that we should halt at this place. A goat was sent me as a present, though at the first they would not sell one. I slept in the open. Khatibu said, if I was bent upon doing so, he must likewise; but he was so cold in the morning that he had to be warmed by a novel process before he could walk. He was well trodden upon, literally kneaded by a friendly native." And so on, until the 27 th, when Mr. Alington says :-

"Hitherto we had passed through a very wild country, reminding us strongly of our old neighbourhood, Morumbala. It was covered with magnificent trees, and here and there we came upon a mountain torrent. Altogether it was a great contrast to Zanzibar. Now the appearance of the country began to change, getting a more Scotch look-ferns on the hills, and not so many trees.

"About Ir.3o we came in sight of Vuga, the capital of Usambara. At this point my men begged for powder, and spent some time in firing off their guns. We passed the night in a banana grove.

"September 28th.. Our ambassador went off early to announce my arrival to Kimweri, and returned about noon with a very civil welcome. I was to advance to a little village outside the town, and wait there. So we set out in triumph, horns blowing, and guns firing. Shortly after I had reached my quarters, down came the chief men of the town, bringing a fat cow as a present, and a message also from Kimweri. He would come and visit me on the morrow, and after that I should go to Vuga. The cow was slaughtered at once, and there was feasting and gorging enough to last a long time. I conclude that such solid fare is not common at Vuga, for the elders hinted that it was usual for some of the meat to be given to the bearers of the present. There was plenty and to spare, so of course they were welcome to a portion. I gave them also some coffee, which, however, they did not seem particularly to relish, for they swallowed it off as if it had been some horrible nauseous medicine."

On September 2 th, Mr. Alington went to see the king, or rather Sekalavu, Kimweri's eldest son, who represented his 
father, and who assumed the name of Kimweri; and he thus describes his visit :-

"At the top of the hill, outside Vuga, I found him sur rounded by a number of his soldiers, who made a passage for me to pass through. He is a fat, good-humoured-looking young fellow. I was seated beside him while Khatibu told them of our journey. Then the present was brought, and opened out before all the Court. It consisted of dress and cloth of different kinds. After this Kimweri took me aside, with only three or four of his men, and I set to work to explain the object of my visit.

"I said that we had been long hoping to visit him; that we had come to Zanzibar for one purpose alone, to teach God's truth; that we had left our homes because God had commanded us to go and teach all people; that we desired his permission to build in his country and to teach his people ; and, finally, that if he would be instructed in God's truth, and learn to follow His commands, he would get rathi, satisfaction, now, and when he died he would find a blessing in heaven.

"After he had thought for a little time, he said that he was willing to receive us, but before I built in his country he should wish to know the mind of the Sultan (of Zanzibar) as to the matter of my settling here. He would send men to conduct us to Zanzibar, and a letter to Sultan Majid and the English Consul. If the Sultan was not opposed to my plan, I might return and build where I liked.

"This did not quite suit me. It was disappointing thus to be put off, so I pressed the matter upon him. I represented that as the rainy season was coming on, I should be glad to build at once, and to leave my things here whilst I returned to Zanzibar. But I spoke in vain. Kimweri would hear of no plan but his own. Seeing that nothing would be gained by prolonging our talk, I brought it to a close, thanked him, and said that I must follow his wishes."

Of the climate and productions of Vuga, Mr. Alington, who was there at the hottest period of the year, says: "The early part of the day is very pleasant; the air is cool and bracing, really invigorating; so my time of loitering is spent at least in a healthy place, which is a great blessing. If my eye were but 
well I should quite enjoy myself. I think I never saw so many bananas as are growing all about Vuga. The people dry them and pound them into a sort of cake. They almost live upon them. Honey and ghee are the other products of the country, besides sheep, goats, and oxen. Yams, too, are grown; I have some for my vegetables every day. If I had bread, I should really have all that man can want in the way of food."

On October 4th, Mr. Alington had a long visit from Kimweri : "I told him," he says, "that, as I was to return to Zanzibar, the sooner I started the better. He asked me to stay yet five days, and on the sixth I should depart. $\mathrm{He}$ brought two boys with him and said I was to teach them. I told him I was only a traveller and so could not begin teaching; that he must wait till I had a house built and was settled. I suggested that the boys should go to Zanzibar and be taught there, but to this he seemed in nowise inclined to assent. He then asked me to give him one of my foldingchairs. I had but one, but I was not unprepared for such a request, and had thought indeed of sending it to him when I left Vuga. He brought a native doctor to prescribe for my bad eye. This was the treatment: A quantity of herbs was put in a jar of fresh water; then a double circle of twisted grass was made and dipped in the mixture; this the doctor held close to my eyes like a pair of spectacles. $\mathrm{He}$ then put the grass round my neck, and directed me to bathe my eyes with the herb-water, which I did. I am afraid I encouraged belief in fetish, as the old gentleman muttered a good deal of something or other during the ceremony."

Day by day, however, Mr. Alington's departure was delayed, until he grew weary of Kimweri's to-morrows, and it was not until the 4 th of November that he was able to commence his return journey. Kimweri, it was found, was at first suspicious and afraid that Mir. Alington's request for permission to build harboured some deep design upon his country; and when he finally gave him permission to erect a mission-house at Magila, it was on the condition that it should not be built of stone, so as to serve as a fort. Nevertheless, his kindness and generosity did not fail, and when Mr. Alington left him he desired him 
to return soon, and he would send bearers to the coast to meet him.

The journey down to Zanzibar was very tedious and trying. It took fifteen days. And the day after his arrival Mr. Alington was laid up with fever. The attack was not a severe one, lasting only three days. When he descended from the hills into the flat country the heat became most overpowering; it was like entering an oven. Day and night the thermometer in a dark room stood at $88^{\circ}$.

Very sad tidings met Mr. Alington on his arrival at Zanzibar. Mrs. Drayton had died on November i 7 th after a very short illness. Mr. Drayton was very ill, and on the 28 th he too was called to his rest. Happily the Mission party had been reinforced, before this loss was suffered, by the Rev. W. Lea, Mrs. Lea, and Miss Pakeman, who had been enlisted in the service of the Mission by Bishop Tozer in England, and arrived at Zanzibar on November $2 \mathrm{~d}$.

When Mr. Goodwin left the Mission the boys became Mr. Drayton's particular charge, and they were of the greatest possible service during his illness.

Writing of these boys some time before his death, Mr. Drayton said: "I keep school for four or four and a half hours every day, and of course the boys take up a good deal of my time besides. I was very much pleased with them when I came, and I see already some improvement in most of them. Taking them altogether, I should say they are quicker than most village boys in England. Most of them are far quicker than the Kafir boys we got together at St. Mark's.* Kongu I like very much indeed; he has got on rapidly, and I think we should do well to keep him, if possible, and train him as a teacher for the smaller boys, beginning to pay him for his work before very long.

"M'wamba is very well now. Three or four bottles of shark oil that we gave him some months ago made quite a man of him, although he does not look as if he would ever be strong.

* While waiting for an opportunity of joining the Central African Mission, after Bishop Mackenzie's death, Mr. Drayton attached himself to St. Mark's Mission in Kaffraria. 
"Makanyassa is one of the printing apprentices (Dr. Steere had set up a printing press some time before), and so is not more than half his time in school. He is backward in his reading, and in this he does not seem to advance; but he is careful, and very far from being stupid in most things."

In a similar way he describes Mkono, Zafarani, M'lankulu, Songolo, Kongu, M'wamba, Baruti, M'gendua, and Baraka; and then goes on to speak of four new boys that had been received from the Lyra and the Highflyer, concluding his letter thus :- "Occasionally we sing a great deal. At Christmas we learnt two carols - 'Earthly Friends,' and 'Good Christian men ;' and we sang them on Christmas Eve on the beach before the English Consulate and before Mr. Witt's house. Both he and Dr. Seward were very much pleased, and gave the boys cakes and fruit. We sang the carols again in chapel in the afternoons of Christmas Day and of the Epiphany. Some of the boys read Steere's translations very readily now, and I constantly make them write English and Kiswahili words and sentences. I shall be very glad when we get some maps for them. We shall soon want fittings for the chapel at the Shamba" - as the Wells Tozer Fund estate came to be called. This place was intended to be the training ground for native missionaries, from whence it was hoped that a succession of ambassadors for Christ should go forth and proclaim to their brethren of every tribe the good news of the Gospel.

It. was not long before Mr. Alington obtained from the Sultan of Zanzibar the letters recommending Kimweri to permit him to build in Usambara, and on Monday, January 2oth, 1868, he left Zanzibar for Tangata. The following narrative shows how he was able to lay the foundations of mission work on the mainland. He thus describes his experience :-

"I went to Vuga by the old road over the mountains, but our men were so knocked up that we determined to leave the hills and go through the Wazegua country. The last day we came in for a Wazegua war party, who came to attack the village in which I had a few minutes before taken up my quarters. They were much put out by seeing a white man. After a great deal of violent talking they left. They shot a 
man at the next village lower down. The reason of all this was:- The people on the plains had had no rain; those on the hills had plenty; therefore the highlanders had used medicine against the lowlanders, and must be punished.

"The next day I went to the village from which the war party came, and they were all very civil to me. I am no stranger to African curiosity, but I must say I never was so mobbed as by these Wazegua. Hundreds and hundreds flocked out of the town to meet me, and when I sat down even a tree over my head was filled with gazers. The town was a large one, built on an island, the only entrance being a narrow plank bridge. It was very hot in the plains, but one could manage to plod on somehow; whereas on the hills the exertion was too great, it was simply heartbreaking.

"I went along for two days, and then turned up to the hills again, and sent to Kimweri. I found he had the smallpox, and was not to be seen. I re-occupied my old hut, or rather the roof of it, for the sides had been taken away. After a few days came a message to visit young Kimweri. He promised to send men to build for me at once; but I soon found out that this was not to be the case, for after many interviews he told me plainly that old Kimweri had said it was not good that white men should live in his country. He told me, however, that I might go to a place at a distance from Vuga, and build there. Of course I could do nothing but follow his orders. $\mathrm{He}$ gave me three oxen, and a man to order bearers on the way, and off I set.

"It was weary work crawling out of the country, but at last we reached the place (Magila) where I had leave to build. The chief is a son of old Kimweri, and quite a young lad. $\mathrm{He}$ was very much startled at the idea, and took me to his uncle, a man of considerable importance, about a day's march off. Here I had to wait whilst a messenger was sent to Vuga, who brought back a favourable reply. When I returned to the young chief's village, I found that he had gone to Vuga, and his people were not willing to let me enter the town. So after a day or two, fever coming on, I thought I had better get on to the coast and wait there. I could only manage to 
crawl along, but I reached the coast on Easter Eve, thoroughly worn out. I wrote at once to Zanzibar for supplies.

"After some days' delay, suffering more or less from fever every day, I started afresh. I took with me only two men. Feeling that I was too weak to walk, I had bought a donkey, and very serviceable this help proved, for the paths were in a very bad state. On the second day I reached Magila. I found the little chief quite disposed to help me in every way. I went up to the top of the mountain to look for a site, but I found it so desolate that I could not make up my mind to build there. At last I pitched upon a little hill close by the village, and near to a lovely stream of delicious water.

"I made a bargain with the chief to build for me, and we soon had men hunting for poles in the forest. I placed the first post on the eve of Trinity Sunday, setting it up in the name of the Holy Trinity, with prayer to God that His blessing might be with us, and the light of His truth go forth from the house now building. I was very ill most of the time I was at the place, hardly ever free from fever.

"At last came a message from Kimweri to our town, saying that all the able men must go to help him in war against Simboja.*

"This put a stop to my building; however, I had managed to get up a skeleton roof, enough to show them how I wished the hut to be made; and so I left for the coast, hoping to return in a short time with various things that I wanted. But while at Tangata I was taken very ill again, and all my strength left me. At length my friend Khatibu, in whose house I occupied a room, insisted that I should go to Zanzibar, and he put me on board a dhow with some rice and a couple of fish. After three days' voyage I reached home, and was hauled up the steep stairs in a lamentable state."

On July $\mathrm{I}$ th, Bishop Tozer, accompanied by the Rev. R. L. Pennell, the Rev. L. Fraser, and a young layman named S. Speare, arrived at Zanzibar from England.

By this time the house at the Shamba was nearly completed.

* Old Kimweri was not dead, and Simboja was another of his sons who eventually became chief of the Wakalindi tribe. 
It was built ${ }^{\circ}$ on rising ground close to the sea, and was surrounded by an enclosure of nearly twelve acres. The first intention was to make the Shamba the head-quarters of the boys; but this idea was abandoned, and the girls were sent there.

On July 3 Ist, the Bishop wrote :- "The school is just now almost solely in my hands (Mr. Lea being invalided). The boys are now thirty-three, not counting S. Speare. The girls are nine. Then we have as day boys Harry Churchill, and some half dozen biggish lads from the town. My four boys (who had accompanied him to England) are veritable sturgeons among these minnows, and promise to be of great use.

"I shall give up for the present all idea of building a church at the Shamba, and make one of the down-stair rooms a chapel. Then if the Mission purchases this house, and a native service which we mean to start at once at all attracts, we may hope to build here, either in the garden or on the other side of the house. There are many advantages in having the School of the Prophets here in the town instead of in the country.

"I have removed the boys' dining-table to the roof, Steere having boarded in the space in front of the kitchen with a wooden lean-to roof. This makes a famous refectory for them."

A suitable opportunity offering, the house was bought. But before this transaction was completed Dr. Steere sailed for England on August 9th, and Mr. Alington returned to the mainland the same day.

Dr. Steere had volunteered to go with Bishop Tozer in 1863 for two years, but he remained well nigh six. His services to the Mission in all its works were very great, and with reference to the Swahili and other languages invaluable. He had reduced the Swahili to writing, and found out its grammatical rules, so that, even before leaving England, missionaries might make themselves, in some degree, familiar with it; and he had made and printed, in Zanzibar, a vocabulary and sketch grammar of the Shambala and Nyamwezi languages, and a rather fuller work on the Yao (Ajawa) language. His translations comprised some of the Old Testament histories, the 
Psalms, the Gospel of St. Matthew, and the Catechism, and other parts of the Prayer-Book.

In giving an account of the Mission at this period, the Bishop wrote:- "Now that Alington is gone, we have converted his room into a vestry. A service for the clergy is said there daily, immediately after dinner. The youngest boys who do not go to evening chapel, also have their evening prayers there in Swahili. The chapel services are beginning to be really nice and hearty ; we have started a practice for the choir every morning before school at 8.30 .

"William Jones and Owen Makanyassa are our head printers, and a proof of some new Swahili private prayers for the household is lying on my table."

Sunday, August 23d, was fixed for the confirmation of the four elder boys-George, John, Connop, and Francis. On St. Bartholomew's Day it was arranged that they should receive their first Communion, and that a batch of new-comers should be baptized. The day was chosen specially as being the anniversary of the first baptism at Zanzibar three years before.

A decided step forwards in the religious condition of the protégés of the Mission had thus been made, and the foundations of a mission amongst the people of Usambara had been laid. 


\section{CHAPTER XI.}

I IFE generally at the Mission house at Zanzibar was not 1 eventful. One day passed much like another, with its customary round of duties and occupations, and beyond the arrival of a ship, or a bag of letters from home, there was little to cause excitement, or to vary the tenor of the daily course.

In September Mr. Lea was sent off to Seychelles for a change, and the Bishop suffered from a short attack of fever. A letter dated Magila, August 23rd, was received from Mr. Alington, in which he said:- "War has been going on for some time between Kimweri and Simboja. The latter made a strong attack upon Vuga and has destroyed the town altogether. Kimweri escaped, but lost all his clothes and valuables.

"I had a more favourable voyage this time, better weather and a better boat. I went over to Pangani to see the Governor, and as my donkey was dead I had to walk a long journey of six hours, returning the next day. The worthy man gave me another donkey, rather a small creature, but good for its size. After a short stay on the coast I set off for these parts. Such a wet journey I had. The paths were so slippery that the donkey could not keep its feet, so I had to drive it on before me.

"The people were very civil to me when I arrived, but nothing more had been done to the hut, and the villagers were many of them gone to the war. I set to work with my own three men to build a small hut. In spite of their laziness we have in two days got a good deal of the framework done. I hope to finish it before I go to the coast, so that I may have a hut of my own when I return with more baggage. The neighbouring villages are all friendly. 
"An old chief with whom I stayed the other day asked me if I could give him medicine for his well. It was dry, and the people had to go a distance for water. I suggested that he might dig it a little deeper and try what that would do, as I had no medicine for such a case.

"August 3oth.-I am thankful to have a day of rest after one of the hardest working weeks of my life. Early and late I have been occupied clearing ground, and building. I am more and more satisfied with the site I have chosen. Though it is close to several villages, it is yet quite separate from them, and on its own hill.

"The Massai, a warlike tribe, and the terror of all this country, crossed my path the other day on their way to lay waste the Wadigo country. We hear many rumours about them.

"The oxen that I left here when I went to Zanzibar, I found on my return represented by three skins. The men said they died; I think they wanted meat.

"After four more hard working days I was able to finish the two huts after a fashion, making walls of rushes tied on over the woodwork. They look very comfortable; and I have cleared a good patch of ground round them, so as to make all safe in case of a bush-fire.

"September $5^{\text {th. }}$-I left Magila by moonlight, and made a long day's journey in order to reach the coast without sleeping in a native village. Thanks to the donkey, that carried me bravely, I was able to reach my own room in Khatibu's house by sun-down.

"September 7th. - I am beginning to think of getting ready for another journey to Magila, with some articles wherewith to furnish the huts, - pots and pans, chair and table."

Mr. Alington remained on the mainland until October, during which time he had no return of fever, and kept in good health.

Early in November another expedition to Magila was made, the party consisting of Mr. Alington, the Bishop, Mr. Fraser, William Jones, a layman then working at the mission, and two of the boys, Connop and Francis.

The account of this journey was written by the Bishop. 
When the party landed they were met by Khatibu, who was the proprietor of the only stone building of which the little town of Morongo could boast. At that time only two of the rooms of this house were completed, and of one of them Mr. Alington was regarded as the tenant. "Alington's room," says the Bishop, "was fitted up with all sorts of ingenious devices, and contained everything that was needed to make us comfortable, only the absence of windows made it feel extremely close and stuffy. As the night was likely to be fine I decided on establishing myself in the courtyard, in spite of Khatibu's anxieties on the score of leopards.

"We rested all Wednesday, and the actual start did not come off till latish on Thursday afternoon. We left in two canoes, the bearers having gone on in front earlier in the day.

"Besides ourselves we had now Kifungiwe, Alington's little chief, who had come down to the coast with him, and had waited to escort us, and Khatibu our good friend.

"In about a quarter of an hour we were set down on the other side of a creek, where the bearers and Alington's donkey were awaiting us. Staying only so long as ordinary politeness required, and making ourselves amiable by drinking 'madafu,' we began our journey, almost every one in the village turning out and accompanying us for some way, with every expression of kindness and good-will. This first day's march was not to be a long one, but it was very pleasant, and just at sunset we came to our halting-place.

"Often as I have camped out, I think I never was so much struck with the exceeding picturesqueness of the scene as on this night. The entrance to the village, through double gates in a sort of stockade fence, and the lofty trees on either side, and banks of shrubs and creepers, gave the effect in the twilight of our passing into some rustic Petra by a bowery kind of defile, and then the opening out of the place itself kept up the illusion. We quickly were cooking, and making our beds; and the bright fires on every side-our large one in the centre, and many others inside the huts-produced an effect of light and shade which I shall not easily forget. We had a little service before turning in, and sang: 'As now the sun's declining rays.' 
"We were up decidedly before the lark, and got away somewhere about four o'clock, with a lovely moon shining down on us and turning night into day. About nine we gained the summit of a stiffish hill, and came to a halt just outside a stockaded village. Here we cooked and rested.

"In an hour and a half we were off again; and now the country became more hilly, and the grand mountain-range was continually in sight. We had fears how Fraser would stand the long trudge, so he was put upon the donkey for this stage. At last we reached a village, the chief of which is called Dawa (medicine), and we were beguiled into resting for nearly two hours by our host's great hospitality.

"Our road now for some miles lay through well-cultivated shambas skirting the little river which in time was to conduct us to Magila itself. On the ground above the shambas we could see peeping out here and there quite a line of villages, each with its stockaded entrance. The whole lóok of the country hereabouts was very striking; on the right the Vuga range, with magnificent clefts and gullies, and covered with luxuriant forests; between, a broken rolling stretch of country, full of underwood, and intersected by the little stream in the valley; while the path itself was leading us along the side of a slanting hill, planted, as I have said, with numberless shambas, and studded with mhozo and bananas, papais, and here and there a few cocoa-nut trees.

"The length of the day's march now began to tell on us all. Punda (the donkey) was evidently weary; the bearers were nowhere in sight; the path appeared interminable, and its ceaseless turnings and windings almost provoking. At last the river was reached, and we threw ourselves down on one of its banks, while the outpouring of a neighbouring town, which had been rushing before, with, and after us, for the past quarter of a mile, had an opportunity of gazing at us to their hearts' content.

"Now for the final push forward. 'About half an hour,' says Alington, and on we go; bearers all far behind.

" Had we been in better heart and spirits, I think we should have been much struck with Magila itself. The huts of the 
station are built on the top of a round hill, itself low ; on every side rise higher well-wooded hills, while right in front stands the first of the Vuga ranges, with a little valley lying between, across which, as it seems, you might easily shoot an arrow, though, of course, in reality it is much wider.

"We arrived a little before sunset. I was so tired that I could only think of bed.

"The next day was spent in various ways, according to the taste and capacity of the individual. Alington devoted his morning to killing and cutting up an ox.

"The following day, Sunday, was spent very quietly." I almost felt the fatigue of Friday more on this day than on Saturday. Many people drop in and chat pleasantly enough at the door of one's hut. They call themselves Washenzi.

"Next morning we started early on an excursion to the top of the opposite mountain, our pleasant little chief Kifungiwe acting as guide.

"Tuesday, we visited Kifungiwe's village, and walked about in the neighbourhood, and made our preparations for the return journey.

"Wednesday, we were up betimes, and got away somewhat before sunrise. Alington came with us as far as Dawa's village, and there we parted, he proposing to go once more as far as Vuga.

"On the following day we left Morongo with a pleasant breeze and came to an anchor soon after dark under the lee of an island called Masiwa. The next morning it was a dead calm, and there we lay and tossed and rolled for many a weary hour. In the evening we anchored off the north end of Zanzibar (island), within sight of Kogotone, and the following afternoon (Saturday, November I4th) we landed just outside the Mission house. We were not expected back so soon. Thank God, we found every one well."

On November 3 oth, the Bishop reporting upon the condition of the Mission, says:- "We have had fourteen more boys made over to us, bringing up the total number to fortyone, the girls remaining at fourteen. Alington is still on the mainland; Lea at Seychelles; Pennell has had a slight touch 
of fever, but is quickly recovering. I am myself quite well, except as far as my hand is concerned, which is becoming each day more absolutely useless."

The weakness in the Bishop's right hand was the result of the illness, thought to have been produced by sunstroke, which compelled him to leave Zanzibar in 1866, and it increased so much at times that he was unable even to sign his name.

Towards the end of the year Mr. Lea returned from Seychelles, apparently much better in health. On Christmas Eve the Rev. S. Davis, who was ordained by the CoadjutorBishop of Edinburgh for the work of the Mission, arrived at Zanzibar. Early in January Mr. Alington, who had received a summons from home which could not be resisted, left Zanzibar for England. Before the month was out Miss Jones was brought in from the Shamba very ill; and in connection with her illness the name of an old friend of the Mission, Dr. Kirk, who had been appointed Consul at Zanzibar, once more appears as the good physician to whose unremitting care it was owing that a valuable life was again saved. Soon after Miss Jones was taken ill, the lady who was her companion in work, unable to bear the solitude of her position at the Shamba, broke down also, whereupon the Bishop resolved somewhat suddenly that boys and girls should change houses, and he, Pennell, and Davis, migrated with the boys, forty-one in number, to the Shamba, Lea remaining in charge of the mission house.

"Nothing," writes the Bishop, "can exceed the beauty of this place (the Shamba). We are all charmed with it, and while lessons go on with due regularity, the making of various little improvements gives us ample and pleasant employment during our leisure hours. The abundance of good spring water in a country like this is a great luxury. We spent a quiet but very happy Easter out here. Strange to say, no one had sent us an almanack, and there was not one to be had in the town, so that we had to calculate Easter by the PrayerBook!"

The great want of the Mission was more clergy, and this want was making itself felt very keenly at this time; for Dr. 
Kirk had given an opinion that the state of Mr. Lea's health did not allow of his remaining at Zanzibar; and though he could ill be spared, it was decided that he should return to England. The Leas, accompanied by Miss Jones, left Zanzibar in June 6th, but fortunately Mrs. Packe, a lady who came out as a relief to Miss Jones, arrived at the mission on the 14 th of the same month. The boys then returned to the mission house, and the girls to their old quarters at the Shamba.

About the end of March Mr. Fraser had left Zanzibar to take charge of the mainland station. Kifungiwe gave him a cordial greeting. After being some time at work there, Mr. Fraser says :- "Kifungiwe has been regular in coming almost daily to be taught; and Sago-sago, from Kisiwani village, attends also. They have been pretty often to morning prayers on Sundays. Sago-sago is a sleepy, good-tempered creature, rather slow at learning. It is not easy to get an evening congregation just now, the people mostly working till late at their shambas. The mahindi is ripe, and the rice is coming on. It is plainly rather a busy time. One or two other people show signs of a wish for regular instruction, but as yet I have no children."

Towards the close of June the Bishop suffered from a very severe attack of fever, but soon rallied, and then went for a week's cruise in H.M.S. Daphne.

Mr. Fraser returned to Zanzibar in July in such excellent health, and in such good heart about his work, that a special thanksgiving service was held. On August 3 oth he started on his return to Magila, taking with him Mr. Davis and S. Speare, and the materials for putting up a small house, of corrugated iron. The house was 20 feet long by ro broad.

Shortly after the erection of this house, which was fitted up to serve as chapel as well, Mr. Davis and Speare returned to Zanzibar, and Mr. Fraser resumed his work amongst the Washenzi. He says of them:- " They are quiet, peaceable, agricultural, and probably rather feeble in character. They keep no large cattle, only a few sheep and goats. As far as I have been able to ascertain, their religion consists simply in a belief in God, whom they call Mulunga, and in evil spirits and 
charms. If mission stations could be vigorously worked at Morongo, Magila, and at Vuga, some effect might really be made; but one man alone feels that the work he can do must of necessity be but very little.

"With regard to language, we labour, of course, as yet, at this early stage, under great disadvantages. The Kiswahili goes a good way with many, but they do not understand it as they do their own vernacular, which is a dialect between Kiswahili and Kishanbala, and which the people call Killionde.

"The children are wild and do not show much inclination to submit to be schooled, though they are less afraid of me than they were; and the parents cherish a lingering suspicion that we want to carry them away and sell them."

In October all were well at the mission house at Zanzibar with the exception of S. Speare, who was consigned for a month to the Shamba. Of the work being done there, the Bishop writes :- "I have now for some time been giving a daily lecture to George, John, and Francis, in the Acts of the Apostles, as a specific preparation for their future work. Yesterday I began a fresh confirmation class, consisting of Arthur, Vernon, Philip, and Preston, all four nice promising fellows. At Christmas we intend to baptize thirteen more boys. And so the work goes on.

"Watching everything as I do, it is satisfactory to notice how now this little addition or improvement, and now that, tend to the more steady working of the machine. Things in this house are now so orderly that the whole establishment is like a piece of clockwork. Pennell is my right hand, and we cannot estimate too highly the value of his labours, or the influence of his self-devotion.

"Our party, alas! is terribly small for the work in hand; and yet it is important to push on with the view of preparing the mainland ground for our elder boys, who will soon have enough feathers to leave the nest."

Some days later, he adds :- "George and John have, after due consideration, chosen the better part, and will, D.V., be solemnly appointed subdeacons at Christmas. Of the two, George has, I think, more character, but they are both good, 
steady, and devout boys; and will, I trust, exercise their office well. I set them down as being about eighteen years of age, so that in five years more we may hope to have them ordained to the Diaconate itself. I feel in this as though the first milestone on the road were in sight."

But a great and terrible trial was impending; the cholera visited Zanzibar, and by the beginning of December the number of deaths had risen frightfully, chiefly amongst the African slaves and the Comoro people.

Processions singing Litanies constantly perambulated the town by order of the Sultan, and, of course, at the mission the Prayer for times of Pestilence was daily used. It must have been very sad to have to sit still and be able to do nothing for those who were dying, but the Bishop felt that he could not attempt anything, as the number of his workers was only just sufficient for the absolute needs of the Mission, and he did not know what might be in store for them.

On Saturday, December 4th, Mr. Fraser arrived from the mainland, and though tired after his journey he seemed bright and well. He and the Bishop spent almost the whole of the afternoon talking over all that had happened since they parted. He agreed to take the service at the Shamba next day, but says the Bishop :- "At ro o'clock (the same evening) he was seized with what proved to be an attack of cholera. Eventually I remained up the whole night with him. Next morning the doctor thought badly of the case. Throughout his illness, which lasted six days, he was restless, but complained of no pain, and appeared to be never quite conscious. He passed away to his rest on Friday, December roth, at four in the morning.

"During Fraser's illness one of our little boys, Peter Chingama, after eating his dinner as usual at one o'clock, came to my room not quite the thing, was speedily attacked, and was a corpse at half-past eight.

"The evening of Christmas Day itself was saddened by the seizure of a second little sufferer, Usuf M'junga. He died next day, just at noon; and some little while after we had said the Commendatory Prayer for him, his large full eyes looking 
at us very peacefully, he left us for Paradise. It was in a way sad, but yet very sweet; the sun shining so bright; the day, the First Martyr's Festival ; and the whole house looking on in silent awe.

"The silence presently was broken; the little boys said, 'M'junga has gone up to Jesus,' pointing with their fingers to the sky. How could any one sorrow much?

"We went down to chapel at $4.3 \circ$, and sang, after the lesson, 'When our heads are bowed with woe.' And then the funeral procession went through the town (to the Christian cemetery), singing, 'O Paradise.' The effect was marked on all whom we met or passed. As we were coming back a kind old neighbour rushed out and seized me with both hands. It was his way of showing sympathy with us in our sorrow. So true it is, 'One touch of nature makes the whole world kin.'"

By the $25^{\text {th }}$ of January, however, the cholera had so far ceased at Zanzibar, that that day, the Festival of the Conversion of St. Paul, was appointed for a day of special thanksgiving, and almost every European in the town came to the service at the Mission chapel.

On the Feast of the Purification, the anniversary of Bishop Tozer's consecration, George Farajallah and John Swedi were appointed sub-deacons.

Upon this the Bishop says :-- "It may be well to state briefly why we have here revived the ancient order of sub-deacons, and what duties we propose to assign to such as from time to time are admitted to it.

"We believe that the solemn admission of our elder boys to a subordinate order of the ministry, is likely to be attended with the happiest results to themselves: for such an office will be a preparation for higher service in the Church; it will bring the candidate's daily life into harmony with his future calling; and it will supply both his superiors and himself with a ready test of his fitness for advancement in the sacred ministry."

The exhortation with which the Bishop addressed those about to be ordained sufficiently sets forth the duties which the sub-deacons are to discharge. It is as follows-

"Brethren beloved, ye are about to undertake the office of 
sub-deacon, for which you are now presenting yourselves to the Lord. Know, then, the duties pertaining to this dignity : for the sub-deacon has not only committed to him the care of the sacred vessels of the church, but, like Samuel of old time, he is the servant of the altar of God, and is appointed to wait on those who minister in the sanctuary. Moreover, to you will pertain the reading of the Holy Scriptures in the Church, the interpretation to the people of the godly admonitions of the clergy, as well as the care and instruction of the young. See, then, that what ye utter with your lips ye believe in your hearts, and fulfil in your daily lives. Let your light so shine before men, that they may see your good works, and glorify your Father which is in Heaven. And, as the Apostle says, 'Be blameless and harmless, the sons of God, without rebuke, in the midst of a crooked and perverse nation. '"

Towards the end of February the cholera again broke out in the town, and again the hand of death was felt in the Mission house. George Farajallah, one of the sub-deacons, and the senior of the house, was attacked on March 2oth, and died the following day. On April $\mathrm{I} 3$ th, another of the boys died of the same disease, and others were seized by it, but recovered.

In this time of heavy trial the Bishop was left with only Mr. Pennell, for the Rev. S. Davis sailed for England on March Ist. But in April Mr. Morton, a schoolmaster, accompanied by a missionary pupil, arrived at Zanzibar, and proved a pleasant and useful fellow-helper.

The panic about the cholera was great, and ships avoided the port of Zanzibar; but on May I8th, by which time the epidemic had really ceased, and the weather was delicious, cold at night and fresh all day, a small schooner came in from Seychelles bringing a mail, which informed the Bishop that another clergyman, the Rev. O. Handcock, was coming out to the Mission.

Soon after this the Bishop made a flying visit to Magila, which he reached on Ascension Day. The ravages of the cholera had been great on the coast and in some other parts of the country, but Magila had been free from it. Kifungiwe had been superseded as chief, but the Mission house and 
property had not been interfered with. On the return passage from Morongo the Bishop had a slight sun-stroke, and was carried by night from Kokotoni to the Mission house. He was for a time very ill, but by the middle of July had regained strength.

Early in August the Rev. O. Handcock reached Zanzibar, accompanied by a lady who was to assist in the management of the girls' school. It was intended that he should have for his charge the station at Magila. But before occupying Magila it was determined that a visit should be made to Kimweri's successor, who had sent a friendly invitation, accompanied by a present, to Mr. Fraser to visit him. Accordingly Mr. Handcock with Mr. Pennell left Zanzibar on September ist for the mainland.

On their arrival at Magila on September 6th, the people flocked in from all quarters to welcome them; Mr. Pennell preached to them, and felt sure from their eagerness to hear him that Mr. Fraser must have made a great impression on them. "After I had finished," says Mr. Pennell, "an old man, who lived in a village four hours distant, told me I should do better to say fewer words, and to repeat them over and over again, that they might be able to remember them. I saw several of the children who had been under Fraser's teaching; one of them knew the Lord's Prayer perfectly, and a great part of the Creed, and assured me that he said it every day when the sun was there and there, pointing to east and west. Several others knew them more or less perfectly. When I had them in our little chapel to pray with them, they all joined very intelligently in the responses. The service was a short one in Swahili which Fraser had used."

On September 9 th the party left Magila for the headquarters of Chengenzera, the chief of Usambara, and on the I 5 th they reached their destination. Next day the chief paid the missionaries a visit of ceremony. According to Pennell, he was a pleasant-looking man, about twenty years of age, and dressed in the present Alington had made him three years before. $\mathrm{He}$ gave the missionaries a hearty welcome, and also permission to go about his country just as they liked, but owing to the con- 
stant wars in the hill country he would not allow them to build anywhere up there; they might, however, build to any extent at Magila, which was always at peace; and if they could collect children there, they were free to do so.

On their return journey they retraced their steps till they crossed the Rengera river, then they followed a shorter route to Magila, which they reached on the Igth, towards evening.

Handcock was very ill when he arrived at Magila, and all the symptoms of his illness seemed to indicate sunstroke. After remaining at the station over the 2 oth, the missionaries pressed on to the coast, Handcock being carried the first day and part of the second. He arrived at the Mission house at Zanzibar on the 26 th much exhausted, and entered on his rest early in the morning of the 29 th. The death of Mr. Handcock was a great shock to all at the Mission; upon Mr. Pennell especially the blow fell very hard indeed.

The remainder of the year 1870 and the year $187 \mathrm{I}$ were comparatively uneventful. The number of the children supported by the Mission steadily increased; the few workers at Zanzibar upon the whole kept fairly well, and though trials and difficulties were not wanting, still the work progressed steadily, and without painful interruptions.

In April Bishop Tozer wrote :- "In many ways my present lot is a very happy one, but the suspension of work on the mainland is an ever-pressing sadness ; and yet I cannot see my way to advance. Our clerical force is too weak; we could do anything-God helping us-if we had but more clergy. Pennell is not quite the thing just at this time, nor, indeed, am I; were we merchant clerks we should be packing up for a furlough either in Europe or elsewhere."

In July he thus reviews the work of the Mission:- "In September 1864, we were two workers with five boys, all small and young enough to be always spoken of as children, of whose different languages we knew nothing. Now, in $\mathrm{I} 87 \mathrm{I}$, two of these are sub-deacons, and working very satisfactorily; and behind are ranged nearly a hundred boys and girls, all more or less advancing along the same road, and giving generally fair promise for a future; while we have a daily 
service in one of the native tongues-the Swahili-conducted by one of our sub-deacons. Surely, herein, is cause for much thankfulness and encouragement; and if we can only wait patiently for seven or ten years we may fairly expect a good return upon our expended capital, that capital being not larger than the parochial staff of one parish at home."

In September he adds :- "During the past few months our printing press has again been set in motion. By its help we have made a beginning of a Mission prayer-book, and some authorised prayers will very shortly be distributed. But the first really great work, which is being got ready for the press, is the Gospel of St. Luke in Swahili. The translation is now complete, and after undergoing a careful revision, already in progress, it will be put into the printer's hands.

"Dr. Steere's 'Hand-book of the Swahili Language' has arrived, and I believe it has already secured for itself a wide circulation. It is pleasing to know that the ships of H.M. Squadron on this station have been ordered to supply themselves with copies.

"We began to be rather overcrowded at Kiungani, and our ground there is not productive. It is like Jericho: the situation is pleasant, but the ground is barren. We have again and again wished to get some better spot on which we could exercise our boys' labour more satisfactorily, and with some profit.

"This led to our looking at what we have come to call the Point Shamba, which the owner was willing to sell. It is beyond Kiungani, farther from the town, stretching down to the beach, and with a small house upon it. The extent may be some thirty acres, and it is unusually well stocked with fruittrees. It is really a lovely spot. The house is just what we wanted, with one exceedingly nice room upstairs and three down. We have been able to purchase this property with some private means at our disposal, and without trenching on the income of the Mission.

"My plan is to fix here all new-comers, and so gradually move them on to Kiungani as they exhibit progress in their schoolwork. I have hopes that it will work in well with our other places, and give completeness to the whole system of schools; and, what is important, it will provide a field of useful employ- 
ment for such of our elder boys as grow up decent and respectable, but whose vocation is not that of the ministry."

The next information of importance is under the date of November 6th, and it runs thus :- "At last, I am glad to say, we have finished and opened the Shamba Chapel, and very nice and religious it looks and feels. It is about eighty feet long by twelve, and we have dispensed with chairs and seats of every kind.

"'The event of the opening was dear good Sam Speare's ordination as sub-deacon, than which nothing has given me more pleasure and satisfaction for many months. He is now installed at Bweni, in the New Shamba, with all the smaller and newer boys, sixteen in number; and that part of our scheme seems to be everything that is nice and promising.

"The chapel-opening was on St. Luke's Day. The service was a solemn celebration of the Holy Communion, with the ordination coming in after the collect.

"We could not get the cemetery ready for consecration, so that stands over for another time."

The cares and anxieties of his position told about this time very severely upon Bishop Tozer's health, and Mr. Pennell was suffering also. It was then that Dr. Steere resolved to go out again, and this time he resigned his English living. In company with Miss Tozer, who proposed to stay a few months with her brother, Dr. Steere left England for Zanzibar in the Abydos, the ship which took out the Livingstone Search Expedition Party, and on the I 7 th of March rejoined the Bishop.

Writing on March 25th, Miss Tozer says :- "We arrived at the very nick of time, when every one was worn and harassed by a wet season, and by the utter absence of home news. The rains are still constant, and we have thunder and lightning every day.

"We came in on Sunday morning, and till we passed his windows, the Bishop had no idea that I was on board; he never even thought of Dr. Steere till he came out to the ship. I think the joy was almost too much for him."

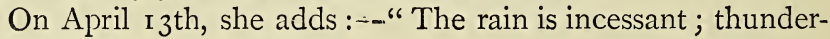


storms daily and no sun; quite curious weather, and it has been going on so for the last two months."

This weather was the prelude to a terrible hurricane on the I5th, which wrought fearful desolation in the town and throughout the island of Zanzibar. This was the more extraordinary, as Zanzibar is out of the ordinary line of hurricanes : they seldom come so near the equator, and in Zanzibar none had ever been known.

In the harbour, before the storm began, there were the Sultan's fleet, some European vessels, and a hundred and fifty dhows, many of them loaded ready for their voyage to Bombay, but of all these ships when the storm ceased only the Abydos remained afloat. The dhows had been broken into pieces, the Sultan's ships were wrecked, and the European vessels were driven ashore. On land things were, if possible, even worse. In the town, the larger houses were unroofed, and battered about as though they had been bombarded, and the sea-walls which protected them from the sea were washed away; the smaller houses and native huts were almost all destroyed, and the streets were blocked up with their ruins and contents. In the country, the clove-trees, the chief source of wealth, were killed, and the cocoa-nut and other fruit trees were almost all blown down.

The Mission suffered severely. The house was unroofed, the out-buildings ruined, the wall and entrance-gate thrown down, the front rooms, including the chapel, were filled with sand and water; the garden, which the day before had been filled with cocoa-nut palms, bananas, and stately rows of aloes, was swept bare of every tree, and filled with planks, stones, and wreck of all kinds.

Towards the evening the storm began to abate, and Miss Tozer says :- "We had just assembled in the least exposed room, and were trying to arrange some plan of sleeping after what seemed to have been a week of watching and labour, when a boy came to say the sea-wall was down. This proved to be true, alas! and nearly the whole of our terrace was washed away, the tide rising and beating against our house in a way to threaten its foundations. There was a hurried consultation, 
and it was decided that we must leave instantly. In the darkness and storm the Bishop carried our invalid (Mr. Pennell, who was prostrated with fever) downstairs through the ruins and into the neighbouring house of Mr. Rieck, which being farther inland was safe, although only one room in the whole house was habitable. We all followed by degrees, and were made welcome by the hospitable German merchants, who gave up sofas and easy-chairs, and did all they could to ensure us a little rest.

"All the consulate houses, which, like our own, are built close to the beach, were so much injured and endangered by the high tide that nearly all their inhabitants followed our example, and sought safety in more sheltered houses during this night.

"I think we feel the ruin of our chapel most. So many beautiful things had just come in time for Easter, the gifts of various friends. The Sultan's steamship had brought us a new Persian carpet, which, of course, had been devoted to the chancel; the corona had been up but a few days; and the organ had just been put together on its return from England. New hangings, frontal, and cushions, all had looked so festive last Sunday; and now the chapel is not only empty, but the very access to it is cut off by the fall of the sea-wall, and it must be months before we can look forward to rebuilding this."

Describing the effects of the storm, the Bishop says :- "The scene of desolation on every side is the most piteous sight I ever beheld. I suppose a cannonade would have more utterly destroyed the larger buildings, but it could not have so entirely left thousands and thousands of poor creatures so wholly without house or home. It is marvellous that we are as we are, all mercifully spared in life and limb. The Mission losses are heavy, and, of course, it throws us back in many ways ; but yet it is not well to speak as though God's work were at all circumscribed by events such as these, and I daresay, as days go on, we shall see some merciful purpose in what has happened."

After this terrible hurricane there naturally followed a period of great depression. All the Europeans fell ill, Dr. Steere had 
the worst attack of fever he ever experienced, the children connected with the Mission were so sickly that many of them died. Mr. Pennell, one of the saintliest of men, whose life was an exemplification of self-sacrifice for Christ's sake, died, Bishop Tozer's health broke down completely, and he left Zanzibar. For a time he stayed at Seychelles, from thence he came to England, and finding that his health did not sufficiently improve to warrant him in returning to Zanzibar, he resigned the headship of the Mission in April 1872. 


\section{CHAPTER XII.}

$\mathrm{B}^{\mathrm{Y}}$ the death of Mr. Pennell and the departure of Bishop Tozer, Dr. Steere, who was now the only clergyman left at Zanzibar, was in charge of the Mission. "It seemed," to use his own words, "as though we were come to the last extremity." But he set to work vigorously to repair the damages caused by the hurricane; and in October 1872 , he wrote :- "We are looking anxiously forward to the time when our new buildings shall be ready for occupation, and the dormitories swept away by the hurricane shall have been replaced. At present we are dreadfully overcrowded.

Khatibu came across from Morongo the other day. $\mathrm{He}$ asked me eagerly when we were going to reoccupy Magila. He told me that the wars in the Shambala country consequent upon the death of Kimweri were at an end, all parties having given up fighting from sheer exhaustion. Magila does not seem ever to have been the scene of actual war, and our house and goods have been scrupulously respected. One effect of the desolation of the interior has been an increase of the population round Magila.

"The people, who cherish a vivid recollection of Mr. Alington, and who had evidently a great love for Mr. Fraser, are all asking when the white men are coming back to them. You will readily imagine how much I longed to do something, especially as our sub-deacons are now old enough and men enough to be sent to actual mission work. It seems also desirable to move off the elder scholars, so that little offices of trust may be given to the younger lads, who are rapidly following them. Francis Mabruki had expressed a strong desire to be sent to Magila, the Bishop having always laid before the sub-deacons the prospect of their going sooner or later to some station on the mainland. 
"I could not, however, send him alone; so I asked Mr. Speare, our English sub-deacon, in whose solidity and steadiness I feel the utmost confidence, whether he would be willing to go. He told me that he should like very much to do so, especially if he might look upon it as his own sphere of work, so that if he goes home, as before long he ought after five years' residence here, he might consider Magila as the home to which he was to return, and the Shambala Mission as the work for which he was specially to qualify himself.

"Under the circumstances I could not have desired anything better than this. Then I found that John Swedi, the other native sub-deacon, would like to go also. Thus a plan seemed to shape itself that Speare and Francis Mabruki should go up first, and look at the land, and get the house and place in order, and when they reported all ready, that John should follow with the wives and children. (Francis and John were married to two of the young native Christian women that had been trained by the Mission.) Thus the two native subdeacons would permanently occupy Magila, and Mr. Speare would spend most of his time there."

It was determined to put this plan into execution, and all preparations being completed by October 8th, on the morning of that day all the Europeans and five of the native African lads came in to an early celebration of Holy Communion, when Dr. Steere gave an address to those about to leave; after which they sailed for Morongo; from whence news soon came of their safe arrival at Magila.

Little by little the Mission work at Zanzibar began to revive. "And then," says Dr. Steere, "came the event which will be a turning-point, not only in the history of our Mission, but in that of East Africa-I mean the embassy of Sir Bartle Frere. England had heard of what Livingstone had seen, and so many others had described, and the nation was moved to do something. At first the Arabs refused to make any change. As they put it, their fathers had had slaves, and their grandfathers had had slaves, and Ishmael had slaves, and Abraham had slaves, and society was inconceivable without them; so there must be slaves, and if so, there must be a slave-trade. 
"The Sultan of Zanzibar holds no legal position in the State, but is merely the strongest chief, who represents the whole body to the outer world so long as he does not offend his great men, and, as he truly said, without their consent he could do nothing. So Sir Bartle Frere left the work to another messenger-the English admiral-who came to Zanzibar with six men-of-war, and to show that we were all of one mind, the French sent two men-of-war, and the Americans one.

"Then the Arabs had another meeting, and looked upon the ships; and some said they would go back to Arabia, but at last they agreed that it would be best to consent to whatever the English wanted, and the treaty was signed.

"This treaty put an end to all juggling with passes, by forbidding all carriage of slaves by sea, and it ordered the closing of all the open slave markets in the coast towns. Thus a very heavy blow was dealt to the slave-trade in East Africa; what its whole effects may be we have not yet had time to see, but they are great already."

Sir Bartle Frere, however, did not confine himself to his negotiations with the Arabs; he examined the country himself, and amongst other things, he made himself personally acquainted with the work of the Mission.

The following information with respect to the Mission was given to Sir Bartle Frere by Dr. Steere :- "The Universities Mission has had under its care, since its arrival at Zanzibar, 78 boys and 32 girls, in all I Io children; of these, all except five boys were released slaves, fourteen of the boys were taken out of the dhows by Seyid Majid (the previous Sultan), and put by him under the care of the Mission; two boys and one girl were procured by Europeans (not British subjects) residing at Zanzibar, and given by them to the Mission; the rest were all taken by English men-of-war. Nineteen children have died; three of the girls are married; two of the boys are subdeacons-one is at Nagila station, the other is preparing to go there ; one old scholar is chief assistant in the printing office, another is employed about the Mission premises, one is engaged as servant to Bishop Tozer, four are in service in the town of Zanzibar, three are engaged as pupil-teachers in the school, 
four have in various ways turned out badly. Forty-two boys and twenty-two girls are now in the schools."

In an official report on the subject of liberated slaves Sir Bartle Frere remarks:-_"The missionaries have laboured at Zanzibar to train selected lads for school teaching and for pastoral missionary work, giving for this purpose, a good deal of attention to both English and the native languages.

"In both respects they have been successful; a fair proportion of the pupils have a useful knowledge of English, and all have learned to read and write their own language, or at least Swahili, the general language of the coast, in English character, in a manner which has hardly been attempted by other missions, and which leaves little to be desired.

"This is mainly due to the labours of Dr. Steere. He has furnished any one who can read English with the means of thoroughly mastering Swahili, the most generally useful of East African languages, and greatly facilitated the acquisition of three others commonly spoken by slaves.

"Very excellent work, in these languages and in English, is turned out at the Mission press, the whole being composed, set up, and printed by regro lads and young men.

"It is difficult to over-estimate the value of Dr. Steere's labours in these two branches of mission work; and nothing seems wanting in either, than to continue and extend what has been so well begun.

"In the benefits of both, as most important auxiliaries in the suppression of the slave-trade, and in the general civilisation of East Africa, the government partly participates. It is to this Mission also that we must, for the present, mainly look for a supply of well-educated interpreters, able to read and write both English and Swahili.

"Judged as a whole, for secular purposes, such as the disposal of liberated slaves, the main defect of the Mission seems to me to be the want of more industrial teaching in mechanical arts or agriculture ; many even of the best selected lads have absolultely no capacity for intellectual acquirement, by means of reading and writing ; and I have heard of 'lamentable failures,' so called, simply because a boy who was quite willing to work 
in the fields for his living, but had no capacity for any but bodily exercises, ran away from his lessons.

"If I might presume to advise the Bishop * and his missionaries, I would introduce a far larger industrial element into their schools. Every one should learn a trade, a mechanical art of some kind, or sufficient of agriculture to support himself. The teaching might be such as a good native artisan, or mechanic, or cultivator could impart; to which might be added, tentatively and with caution, instruction in European methods, and the use of European tools, which are not invariably adapted to African habits and necessities. Every boy should, I think, be taught to make himself useful in building a hut, in cultivating, in managing a boat, and mending his own clothes and shoes, and nets and fishing-tackle, \&c., after the native fashion, with European improvements only when clearly seen to be better than native ways.

"Elementary instruction, sufficient to read and write in their own language, might probably be imparted to all; but only the apter pupils should be required to learn English."

Sir Bartle Frere's hope was to find in the Mission the means of disposing of liberated slaves, and he saw that Bweni, or Mbweni, might be utilised for that purpose, to the extent at least of providing for the temporary reception of any batch of liberated slaves which might be brought in, pending adjudication or awaiting decision - a hope that was destined shortly to be realised.

A few extracts from Dr. Steere's journals and letters will carry on the history of the Mission to the time when he was called to succeed Bishop Tozer as chief pastor thereof.

"March 1873.-Mr. Karn's arrival is an immense advantage to the Mission. He is working well (as a schoolmaster), and is taking a warm interest in the boys.

"Speare is come down from Magila. He seems to be doing very well, and looks to a school for children, and conversations with the natives who gather round him wherever he goes, as his chief present objects. Benjamin Hartley (a young layman

* At this time the fact of Bishop Tozer's resignation was not known to Sir Bartle Frere. 
who had not long before joined the Mission) is to go back with him.

"April.-I think we may reckon that for $£ \mathrm{I} 500$ a year spent here we could keep the two schools going, and two mainland stations. Of course there will be proportionate expenditure at home, which will raise the amount to $£ 2000$;

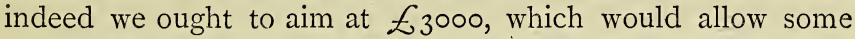
margin for growth. The Kiungani establishment may be set down at sixty mouths, all told ; that at Shangani at twenty-five, and that at Magila at about ten. This last is now being put upon its permanent basis. The sub-deacons are to feed and clothe themselves and their families out of their salaries, the Mission paying passages, house-building, and items not of a personal nature.

"We have finished printing Mr. Pennell's translation of St. Luke's Gospel, and have now in hand the Book of Kings.

"May roth.-Our new recruits, Revs. J. Midgley and A. N. West, have arrived, and we are as yet in the first joys of meeting."

Since the departure of Bishop Tozer from Zanzibar up to this time, Dr. Steere had been without any clerical coadjutor. A little later he writes:- "Do not hesitate to send out any one who is at all promising, and we will make the best of him. My thoughts are full of Kiswara or Lindy as a starting-point for the Yaos and the Nyassa. Gilbert $M^{6} G$ Genda came back in the Natal mail with a very good character from his master; and as they wanted another, Vernon Baruti has gone down this voyage with him. The Natal people seem so eager for labourers that they would carry off the whole town if they could to work on their sugar plantations.

"Now that the slave-trade is become more and more a matter of small smuggling, we must look to the mainland stations for our supply of scholars, and this makes me increasingly anxious to multiply them.

"We must also, I think, be content with a class of Mission priests in whom self-devotion takes the place of learning. If I were bishop I would offer special facilities to earnest men wishing to join us; admit them at once as sub-deacons; then 
make a thorough knowledge of the Bible and a good acquaintance with some native language the conditions of deacon's orders; and so after scme years, during which a few sound standard theological works had been thoroughly digested, admit them to priest's orders. We want all the well-taught men we can get, but we want a great many more besides. We are also in great need of some ladies who would really master the language, and lay themselves out for the benefit of the townspeople.

"July $23 r d$. - Mr. Midgley left us on the 7 th to take charge of the station at Magila. There remains one thing that we must do here, and as speedily as may be, and that is to set up a mission church in the town with regular vernacular preaching. For this purpose I am trying to secure the site of the old slave-market, now closed. We shall then cover the ground here well, though spread out very thinly.

"At Magila there is just now an accumulation of force which only waits for the coming of another priest to divide itself and form another station."

Mr. Midgley's first impressions of Magila seem to have been very good. He writes:- "Anything more charming than the site of this station it is, I think, impossible to imagine."

The people gathered together in crowds to welcome the missionaries, and there were many natives listening during their first service. They found the country along their route much more populous than it had been, and fresh cultivation going on everywhere, especially about Magila. The people gave them most readily the best accommodation they had to offer.

"Our work is going on very briskly. The boys are visibly improving under Mr. Karn's teaching, and Miss Fountain and Mr. West are taking good care of the girls. S. Speare leaves by this mail. $\mathrm{He}$ is of the greatest value to the Mission, especially as the first-fruits of Bishop Tozer's mission pupil scheme. I hope very great things from him, if he gets well through his two years in England.*

* S. Speare never returned to Zanzibar. He was preparing himself to do so, but died before his preparation was finished; but he was fully prepared for the "inheritance of the saints in light." 
"I have just bought rooo young palm-trees for Mbweni. If they do well they will be very profitable. At Kiungani I am planting orange-trees along the paths.

"I find that they are beginning to use our words, and to study our translations, at the French Mission (at Bagamoyo, on the coast of the mainland). I came upon Frère Marcellin the other day, sitting under a bush and working away at our St. Matthew, and Père Etienne was most glad of a copy of our hymns which I showed him. I always make a point of sending them copies of what we print, and so I hope in time to get them more and more for fellow-workers.

"August 28th.-We held our feast on the 25 th. Mr. West is just returned from a trip in H.M.S. Shearteater. They found Kilwa a small poor place, and all about it full of bones and skulls. The slaves were being marched thence up along the coast. He had a day's walk along the shore, and was everywhere treated with the greatest kindness."

The site of the old slave-market was purchased by Mr. West, and made over to the Mission. Dr. Steere was not long before he made use of this site as the place of all others from which to preach deliverance to the captives, as the following details show :-

"December.-Last evening, the First Friday in Advent, I held our first preaching at the slave-market in a mud-house. The boys and girls came in. I preached, and we sang the Advent Hymn and said the Litany all in Swahili. The townspeople were shy and did not come inside till we had well begun the Litany, when twenty or more entered in a body headed by the Imam of a mosque, who is a neighbour of ours, and by way of being friendly. He said they were very good words that he had heard, and not so very different from what he himself thought."

"Our preachings in the mud-house prosper. The arrangements are primitive, and necessarily as simple as possible. Two large poles prop up the ridge of the roof, and we have put some mats on the floor. The east wall is marked by a large print of the Crucifixion nailed up in the middle of it. A good deal of light comes through the thatch as well as by the 
door and light-holes. Last Friday, when we arrived, we found a good many people waiting for us, and while we were singing the hymn they came in and filled the lower part of the room. Miss Fountain counted eighty of the townspeople, so that if I can only hold them we promise very well.

"I am making a little mud bench under the eaves in front, which are very deep, so as to be able to sit there and talk to all comers. I hope to arrange to spend Fridays there, and, if it can be managed, that the boys and girls should meet there on Sunday afternoons; I should then be able to speak to them and the people both at once. I should hope that Mr. West's zeal for a church will rouse everybody to do more in other ways for us."

The congregation of eighty soon grew into one of one hundred and fifty, which included the representatives of many nationalities,-Indians, Persians, Comoro men, Swahili of the coast and of the town, and some pure Arabs, as well as pure up-country negroes.

In the meantime the building of a permanent church was taken in hand and prosecuted with such energy, that on Christmas Day the first stone was laid by Captain Prideaux, acting Consul-General, amid a great concourse of natives, and most of the European population.

"We sang," says Dr. Steere, " 'Jerusalem the Golden,' and I said some prayers and made a short address. The church is to be named Christ Church. There was some slight fear of a row among the Mohammedans, and certainly the way in which they came to hear us, and the interest they manifest in what I say, is most unlike what we might have expected from them. One cannot help feeling how much mission work is really thrown upon England by the marked way in which the people here prefer an Englishman, and listen to him rather than to any other European. Standing almost alone, as I do here just now, the Epiphany epistle was strangely affecting when it came to me to read.

"In connection with the church we propose to establish day schools for the townspeople, who are very anxious to have their children taught, many adults also offering to pay liberally for 
instruction. In addition to this we hope to have a dispensary, of which the consular surgeon is willing to undertake the management."

The New Year, I874, opened auspiciously with a wedding, for on New Year's Day Vincent M'kono was married to Elizabeth Kidogo, and went, to live at Kiungani, where he acted as a sort of usher out of school and general superintendent.

Early in the year also Juma (or Chuma, as he is now called), who had accompanied Dr. Livingstone throughout his last travels, and to whom it was owing that the doctor's body was brought down to the coast, who also was a protégé of the Mission when it was in the Zambesi districts, was added to the number of those connected with the Mission at Zanzibar.

The events of February were some of them sad. Mr. Midgley suffered so much from fever at Magila that he much feared he would have to give up - a fear that was soon after unfortunately realised. Francis Mabruki, one of the sub-deacons, lost his infant child, he being at Zanzibar when it died. Writing upon this to a friend who had been kind to him when he was in England with Bishop Tozer, he says :- "I thank you, indeed, for your kindness in sending poor Flory the things. She is not now with us, but gone up, and has been called by God who made her. Poor child! When I was in Zanzibar spending the Christmas a letter came to me, and I read it, and saw the sad news of the death of my child. Whenever I think of her last little hand-shaking with mine, and her last loving kiss, my tears flow down. God bless the little thing. It is good that God has taken her away from this sinful world into a glorious kingdom."

Mr. Hartley, a schoolmaster, also came down from Magila to spend the Christmas at Zanzibar, and near to Morongo on his return journey he met some Arab slave-dealers who were on their way from Kilwa with two gangs of slaves. Some words seem to have passed between him and them, and then shots were fired on both sides, and Hartley was severely wounded. The people at Morongo put him on board a dhow; which happened to be in the harbour, and sent him across to Zanzibar. At the end of a week he was going on so well, in 
spite of the number and severity of his wounds, that Dr. Steere hoped to be able to send him home by the steamer in March, but lock-jaw supervened, and he died on the $5_{5}$ th of February.

Then came an offer of thirty-four slaves-men, women, and children-that had been taken from a dhow by H.M.S. Briton. The offer was accepted, though Dr. Steere wrote upon this occasion:- "I am so overwhelmed that I know not how to turn. The females are unfortunately all grown women, who must have work now, and husbands as soon as may be. I am very glad to have prepared the way for a settlement of girls at Mbweni, where there will be work for all.

"The house at Mbweni is nearly ready. It stands on the top of a gentle rise from the sea. The upper floor has two long rooms over the schoolroom and temporary chapel, and two small ones over the stores and porch. We have a good water-tank, which will be an inestimable benefit. We begin our village with seven grown men and fifteen women."

At this time Dr. Steere was again alone at Zanzibar, for Mr. West had not intended to work permanently at the Mission, and, after staying at Zanzibar a few months, returned, as had been arranged, to England. Nevertheless, it will be seen from the records of this chapter, that the Mission had not only recovered from the state of prostration in which it was at the time of Bishop Tozer's departure, but that its sphere of operations had been greatly enlarged.

The number of children connected with the Mission had been greatly increased; an asylum for released slaves at Mbweni, which is about four miles from Zanzibar, had been established; religious services and preaching in the town of Zanzibar itself had been commenced; the old slave-market had been purchased for the site of a church, and the church was so far advanced that at Easter it was completed to the first stage of eight feet all round; and finally, the work at Magila had been carried on without any break in the operations for many months.

It was most fitting that when Bishop Tozer's resignation was accepted, the bishopric should be offered to Dr. Steere, for no one had rendered such great and valuable aid to the 
Mission as he, and of all men he was best qualified for the post. For some time, however, he hesitated to accept it, but ultimately he gave way, and having arrived in England on August 4th, he was consecrated in Westminster Abbey on St. Bartholomew's Day.

While in England Bishop Steere was actively engaged in pleading the cause of the Mission. During the last three months of 1874 he was almost every day preaching or speaking in its behalf, setting forth what was being done at Zanzibar, and what his plans and aims were for the future. When at Oxford, after describing the efforts that were being made for the children, he said:- "But then, when one feels that something has been done, there naturally arises a longing to do more ; and the first thing that suggested itself was the desire to do for the adult slaves what we had been doing for the children. Now, the Arabs say of our efforts to suppress the slave-trade, that we are in want of hands for our sugar plantations at Natal and Mauritius, and, being strong at sea, we find it the cheapest plan to take the slaves and send them to work for our planters. What is done, is far too much of this sort ; for to take an African away to a strange country, and apprentice him for a term of years to an Englishman, for whom he will be compelled to work much harder than he ever would have worked for an Arab master, is the strangest possible way of giving him his liberty; yet this is what we do. It is a reproach to our English Government that we give five pounds a head to the men-of-war's men for every slave seized by them, and then refuse one penny for the benefit of the released people. Children, infirm, sick, whatever they be, no schools, no refuge, no hospital, not even a temporary allowance, scarcely any food, are provided. No wonder the Arabs disbelieve our talk about philanthropy.

"But what the State will not, the Church must do ; and I should be ashamed to hint that this Church of England was not rich enough and liberal enough to do all that is required. Many individuals, many congregations, many schools have come forward to help us in our work for the children by maintaining each one or more of our orphan scholars. In like way for the 
adults-we must feed them, and clothe them, and maintain them until they get strength and heart enough to work for themselves. An Arab always reckons the first year of a newcome slave as a loss. At first body and mind are so broken that there is not strength if there were will, nor will if there were strength. We must teach them to trust us, and we must try to set, not the body only, but the spirit free also. Nothing yet has ever uprooted slavery except Christianity. Nothing else will destroy it in Africa. Nothing else will destroy it in a man's heart. You may knock off his fetters, but ships of war and soldiers can never make him really free.

"Just as the outward life of an African is full of fear and uncertainty, so his inward life is all fear and uncertainty too. The East Coast Africans are not idolaters ; they all believe in God, but they think of Him as too great and too far-off to care individually for them. Their whole thoughts are full of evil spirits and malicious witchcraft. A man gropes his way through his life, peopling the darkness round him with fearful shapes, and on the continual look-out for some omen, or for some man who, as he supposes, knows more than he does of the invisible world, to give him some faltering guidance. His life is dark, his death is darker still. His friends dare not even let it be known where his body is laid, lest some evil use should be made of it. No man in the whole world has more need of inward strengthening and comfort, and no man in the whole world has less of it. To talk of giving such a man what he wants most, by getting a few years of work out of him, and then sending him adrift among the dregs of a colonial town to die, as he very often does prematurely, of some disease engendered by the change of climate, is surely ignorance, or folly, or worse.

"If, on the other hand, we can give him a new home in his own land, in which his freedom will be assured to him, and he will be taught lovingly to use it as a Christian, and so in the very face of his oppressors to be a living witness of our charity and our faith-a Christian freeman instead of a heathen slave -then we need never fear that our motives will be misconstrued, or our good intentions perverted. It was with the 
thought of founding such a home that Bishop Tozer bought our land at Mbweni, and when we began to recover from the effects of the hurricane I bought more, and Mr. West, out of his own means, added more; and we have now the beginnings of our Christian village of freedmen there, not more than fifty perhaps as yet, but waiting only your approval and your liberality to expand into its due proportions.

"Then again, when we found that the old slave-market in Zanzibar, the last in the world, was to be used no longer for its old abominable purpose, for what should it be used? The evil spirit was driven out, what spirit should dwell there? The English State had done its part, it remained for the Church to do hers. What place could be so appropriate for the preaching of the gospel of liberty as this, where liberty had been so long unknown? So our good friend West came forward and purchased it for God. There is now the church, already showing its fair proportions, and the schools, already filled with scholars, and the hospital waits only for English alms to build it.

"We did not begin to raise the material church without laying first the foundations of the true Church. I began my vernacular preaching in the old slave-market, and soon the room was filled to overflowing with listeners, and the tracts and papers we were able to print were eagerly snatched from my hands. Africa is ready, if only England be ready too. Look on the two pictures-rows of men, women, and children, sitting and standing, and salesmen and purchasers passing in and out among them, examining them, handling them, chaffering over them, bandying their filthy jokes about them, and worse scenes still going on in all the huts around; and then, in the same spot, see instead the priest and preacher, the teacher, the physician, the nurse, the children crowding to be taught, the grown men coming to hear of God and Christ, the sick and suffering finding help and health. Look at these two pictures, and is it not a blessed and a glorious change, and is it not worth a life to have made it possible?

"But all this is only on the very edge of our work. Bishop Mackenzie's grave is some three hundred miles inland, and he only touched the coast regions. Beyonđ and beyond lie nation 
after nation, until the mind is overwhelmed by the vastness of the work before us. How are these nations ever to hear the good news that we have to tell them? The first starting of this Mission seemed a great undertaking, but its scale was altogether inadequate to the work. We want such a Mission to each of the great nations, and why should we not send one? Because Englishmen are poor? Or are English Churchmen too few? Be it so, then here are our native scholars-the cheapest and the best helpers that we could have for this work. Some of them are now preaching and catechising, some are busy in our school-work, and many more would be able to help in our inland mission.

"My plan is to cut up our work into manageable portions. I think we may take it for certain that we have not to do with broken fragments of tribes, or with little petty groups of people isolated either by distance or language one from another. There seem to be nations, it may be several millions each, speaking the same language, and occupying countries which are to be measured hundreds of miles in either direction. Our East Africans are not nomads, dwelling in a wilderness or a desert, but settled cultivators who would gladly remain for many generations in one place. Each of these nations ought at least to have its own church, and its own bishop and clergy.

"As our preparation for this, we propose to send up first a small party of a few men of good judgment, to make acquaintance with the chiefs, and look through the country, to find the healthiest, most acceptable, and most central spot on which to make our chief settlement. As Africa is now we shall have to fix the site of future cities, as the monks did in England, and the English missionaries in Germany. People will soon gather round us, and, if we choose our place well, there they will remain.

"First of all, we will set up a great central school for the people of that language, and then whilst preachers go out from it to reach every part of the tribe, we will send up, as they can employ them, artificers and workmen who will teach the ratives all that our civilisation can give them. Thus a centre 
of light and life will be formed, and from it that whole people may be enlightened.

"We have such a centre begun at Magila for the Shamba. We are forming a party to go up and work amongst the Yaos, the Ajawa of the early days of the Mission, who now hold all the country in which Bishop Mackenzie made his first attempt.

"Between the Yaos and the coast there is one great nation - the Gindos, who are for the present altogether disorganised by the ravages of the Maviti. We must try to plant a station amongst them. Then there are the Zaramos and the Zegulas, near the coast, the Nyassas and Bisas on the other side of Lake Nyassa, and the various tribes up to and beyond the Nyamwezis, all and each ready to receive us, and would gladly have us amongst them.

"But how is such a work as this to be done? It is a question which you and I can well answer if we will. The question is not how can it be done, but, who will join in it? We have had hitherto four or five workers, we want twenty or thirty at the very least. We have raised hitherto some $£ 2000$ a year, we want $£ \mathrm{Io}, 000$ for such a work as we ought to do. I do not think money will be wanting where work is actually being done, but I mean to leave the raising of money entirely to those in England who desire the good of Africa. I have very much more upon my mind than I can well attend to, of actual mission work. I shall render a full account of how all moneys are spent, and will take care that they are made to go as far as possible; but I will not accept the post of head collector, or attempt to organise a scheme for supporting the Mission. If we are starved for lack of funds, the fault will lie with those who stay at home, and not with those in Africa. Every one, whose heart is touched, is, by that very fact, bound to help and gather help. The Propagation Society will receive money for us, and those who write to me in Zanzibar will have an answer. I do not ask people to help me, I ask them to feel the call from God to do something for Africa, and by me, or by any other agency they like, to do it.

"We have a continent to work upon where chaos still reigns, both in the social and the spiritual world. We have 
the reproach of ages of cruelty and neglect to wipe out. We have the key of the gate of heaven, and millions are waiting for us to open to them. Christian men and women, come yourselves and help them. If you cannot come, seek out and send your best and dearest, that their glory may be yours. If you have money, give it; and that not in little driblets, but as God has given it to you. Do not wait to be canvassed, but canvass others yourselves. Above all, send your hearts with us, and, as you stand in spirit on the edge of that great continent of darkness, do for it with all your might whatever the whispers of God's Spirit may suggest." 


\section{CHAPTER XIII.}

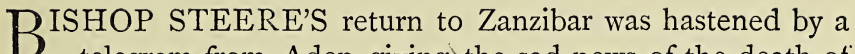
B telegram from Aden giving the sad news of the death of the Rev. A. N. West on Christmas Day, the anniversary of the laying of the first stone of the church with which his name will ever be associated, for to his liberality the Mission is indebted for the acquisition of the site of the old slave-market on which the church is built.

Shortly after his return from Zanzibar, Mr. West offered himself to the Mission for a period of three years, but he was not a strong man, constitutionally unfitted, therefore, for a life in the tropics, and consequently his offer could not be accepted. But when the bishopric was offered to Dr. Steere, Mr. West went out to take charge of the Mission for six months. Till within a fortnight of his death, he had been remarkably well, though there can be no doubt he was overtaxing his powers by the work he undertook. A letter written in November was full of pleas for the extension of the operations of the Mission, and although he said that he should be glad when the time came for his release from the headship, he yet expressed the hope that he might be allowed to remain in the service of the Mission.

Bishop Steere left England on Thursday, February IIth. On the previous Thursday the Rev. E. S. L. Randolph, and a lady worker, Miss Bartlett, sailed for Zanzibar, and these were followed on the 25 th of February by the Rev. J. P. Farler and five laymen. It was also arranged that the Rev. C. A. James, who had offered himself specially for the intended Nyassa mission, the Rev. W. Forbes Capel, some laymen, and a staff 
of nurses for the hospital work, should leave England for Zanzibar as soon as possible.

The same mail which brought the details of Mr. West's illness and death, also brought the news that, pending the arrival of the Bishop, a committee consisting of the Rev. E. L. Penny, chaplain of H.M.S. London, a member of the Consulate, and Mr. Morton, had been formed to administer the affairs of the Mission, and that Mr. Penny had undertaken the chapel services both at Kiungani and Zanzibar, and was rendering most valuable help in many other ways.

Bishop Steere reached Zanzibar early in March, his arrival being preceded by that of Mr. Randolph and Miss Bartlett, and he had scarcely settled himself to work when he was offered a cargo, which he accepted, of forty-eight slaves of all ages.

In April Mr. Farler and his people arrived, in May Mr. James and another lay helper, and in June Mr. Capel. The Bishop was now surrounded by a staff more numerous than had yet been mustered at Zanzibar-a staff sufficient to enable him to strengthen and extend the work of the Mission, though still insufficient for all the branches of work which he desired to see in active operation.

A visit to Magila, with the view of placing Mr. Farler in possession of that station, was first determined upon. But previous to this being carried out, a service was held at Kiungani for the appointment of five readers, three English and two Africans. Matins were said by the sub-deacon, John Swedi, and after prayer for special grace for the candidates, the Bishop gave to each one a Bible, and authority publicly to read the same in the church.

Next day, July 7 th, the Bishop, the Rev. J. P. Farler, and Messrs. Bellville, Beardall, and Moss, with Acland (one of the native readers), Litala, Zebilo, Kelembera, Hallal, Gainsborough, and Chuma, started for Magila. Francis Mabruki, the sub-deacon, had been sent on in advance to get things in order, the station having been for some months unoccupied.

"We made a good passage," wrote the Bishop, "spending the first night at Kokotini; and so across to Morongo. The day after our arrival here we made a start about two miiles to 
Tongoni; the next brought us after some eighteen miles of uninhabited country to Umba. The question every one on the road asked was, 'Is it peace?' Next day we reached Magila. We had had the mountains in sight all the way, and very pleasant they were to look upon after the continual flat of the coast. The whole country around our station is teeming with population, and the greater part is under cultivation.

"As soon as our arrival was known we had swarms of visitors. Kifungiwe, who was head of the district in Alington's time, came and brought us a sheep as a present, while some other head men offered smaller gifts.

"We found Mr. Midgley's large house quite habitable, with a well-filled woodshed, a capital fowl-house and cow stable; and the main road up to the house, which he made, in good order still. The house has a noble verandah terrace, paved with huge stones, which Mr. Midgley moved and placed chiefly with his own hands.

"The day after our arrival, Farler and I climbed up to the top of the nearest mountain, and surveyed the country, and talked over our plans. We saw villages too many to be counted, and in all nooks of the mountain-side little groups of huts and plots of cultivated ground."

Having established Mr. Farler and those who were to be associated with him at Magila, the Bishop returned to ZanziDar, and began to make preparations for a journey to the Nyassa country, with the view of finding suitable positions, among the Yaos, if possible, for mission stations.

In the meantime a confirmation was held at Kiungani on the rgth of August, when nine of the elder lads and nine girls were confirmed.

Great preparations were made for the anniversary festival of the Mission, St. Bartholomew's Day, when the baptisms were more numerous than even in the preceding year, being thirtyeight in all.

A large 'party sat down to dinner in the dining-hall; John Swedi and Owen Makanyaka presiding; Chuma and Susi* being among the guests.

* Susi was Chuma's companion during Dr. Livingstone's last years of travel. 
The Europeans dined in the schoolroom, the dining-hall not affording sufficient accommodation for all the party.

After dinner the children received presents, and the freed slaves were assembled in the large court, and each man and woman received a gift.

Shortly before sunset the cemetery was consecrated. Hymns were sung in procession round the ground,- "When our heads are bowed with woe," at starting, and "Jesus lives," at the conclusion.

Flowers had been placed by loving hands on the graves of the dear departed ones.

Three or four days after this, the Nyassa expedition left Zanzibar in one of the Union Company's mail steamers, and was landed at Lindi on the second day afterwards. The Bishop was accompanied by the Rev. C. A. James, Mr. A. Bellville, and Mr. Beardall, the party whom he hoped to place in a permanent station at Mataka's town (Mataka being the principal chief of the Yaos), or elsewhere near the Lake, with about twenty Zanzibar porters under Chuma and Susi.

The Bishop and party were well received by the Governor of Lindi, and set to work to collect a sufficient number of bearers for the journey. It was soon found, however, that instead of aiding them the people of Lindi were putting hindrances in their way, not openly, but by vexatious delays, and by promises that were never intended to be fulfilled.

Dreading the effect of inaction on his companions, and also having some reason to fear that they might not be able to stand the hardships of the journey, the Bishop sent them on two little exploring journeys-Mr. James to see something of the Mweras and their country, and Mr. Bellville to look for a navigable river said to fall into the sea between Kilwa and Lindi.

On Mr. Bellville's return, the Lindi men being slow to come forward, and standing out for extravagant rates of payment, the Bishop sent him to Zanzibar, with Susi as interpreter, to hire porters.

Mr. James returned so seriously ill from his little exploration that the Bishop could only send him on to Zanzibar, 
accompanied by Mr. Beardall, for advice, and feel thankful that he had not exposed him to the fatigues and risk of a long journey. On Mr. James' arrival at Zanzibar he was moved on board H.M.S. London, and growing worse, was eventually sent off by the Natal mail as affording the best hope of recovery. He reached Natal, but died soon after of the effects of fever.

The party being thus broken up, and the season rapidly advancing, the Bishop had to determine what to do himself. He says:- "I thought it due to our friends at home that I at all events should see the country, and open the way for another expedition. I was anxious, too, that the coast men should not have a triumph over us, as that would have made any future journey still more difficult. Even so, it was not till the Ist of November, a full month too late, that I was able to make a real start. I had about forty men as porters under the command of Chuma as captain of the expedition, and two coast men, said to have great experience as guides. These last turned out to be merely expensive ornaments, but Chuma was throughout the soul of the expedition, and success without him would have been all but impossible."

The Bishop left Lindi with the hope that Mr. James' illness would prove but temporary, and that he and the others would follow in his track; but he nevertheless left instructions that, should Mr. James be permanently invalided, his party was to break up.

Continuing his narrative, the Bishop says:- "The coast settlements end at Ching'ong'o, some ten or twelve miles from Lindi. Thence we plunged into a thickly grown forest, and after a long morning reached Lake Lutamba, a fine sheet of water about five miles long and two or three wide, with high wooded hills all round. We were now fairly in the Mwera country, and stopped at a village close by the Lake.

"We were nine days of slow travelling in passing through the Mwera villages, which lie along a fine range of high hills, with many spurs and subridges, in general direction north and south. Thence we passed to our first stretch of uninhabited forest, and were six days before we emerged upon the belt of villages near the Rovuma. 
"The Mwera forest is very level, and most part of it wet at the wet season, and very scant of water at the dry. We were passing just at the driest time, and had to arrange our marches so as each night to encamp near water.

"There is something very solemn in these huge forests. The men have a superstition against shouting and singing as they do at other times, and the bare feet make no tramp, so that the only sounds one hears are when they pass the word to avoid a stump, or a stone in the path, or an elephant's footmark, which means a round hole a foot or so across, and deep as may happen, or, most to be shunned of all, a line of ants across the path.

"The approach to the Rovuma is marked by the sudden rising of enormous masses of granite rock, often of grotesque shapes, and seemingly strewed about by accident. The country we had passed had not always been so bare of people; it forms part of the great waste made by the raids of the Maviti and Gwangwaras. We found the first village we came to inhabited by Gindo fugitives from near Kilwa, who, being timid folk, are terribly bullied by an otherwise insignificant Yao chief named Golilo. They begged us to make him a present, lest he should revenge our not doing so on them.

"As we passed on we heard that a coast caravan had kidnapped one of the villagers-the first trace of the slavetrade.

"By the roadside I saw an iron furnace, hollowed out of an ant hill. It was not at work, but there was some ore close by prepared for melting, of which I got specimens. The melters are Makuas, but the Mweras are the best smiths.

"We had just crossed a broad dry river-bed, when we met what we took at first for a caravan, but it turned out to be a fugitive chief and his followers who had fled from the other side of the river. They told us that the Gwangwaras were out on a raid before us, that some hunters in searching for game had seen them and given the alarm, so they were fleeing they could not tell whither.

"We went on to a village of some three hundred houses, under a Makua chief. Livingstone had seen the same people 
on the other side of the Rovuma; their chief Makochero had moved to this place.

"From Makochero's we came to the Rovuma. It was then at the lowest, and at the spot without much current, the whole bed studded with rocks and sandbanks and reedy islands. It was fordable in many places and nowhere deep. A more unpromising stream for navigation could hardly be; for some distance a little higher up no water was visible, only a waste of rocks and the sound of water rushing between them. We were three days more passing up the north bank, and crossed two large rivers, still flowing very low, which drain respectively the forest wastes that were once the Gindo and the Donde territories. We crossed at a place where the river was broad and still, but covering its whole bed, and looking more like the great river it really is. The water was nowhere more than three feet deep, and mostly but little above the knee. The men walked straight across, and I was cleverly ferried over a little higher, where there was more current, in a very small canoe."

Having crossed the Rovuma, the Bishop entered the Yao forest, and pursued his journey unmolested, but through a country from which the alarm of war seemed to be rarely absent. After journeying for several days, a large caravan, exporting tobacco and slaves, was met, the leaders of which informed the Bishop that he was five days from Mataka's, his destination, that the road was clear, but that he would find no more villages. This was serious news, for his provisions were nearly exhausted; so that before he and his followers arrived at Mataka's, they were not only very tired but very hungry also.

When nearing his journey's end the Bishop writes:- "The night after crossing the Luatize we soon got good fires and a plentiful supper, and woke the next day on a good specimen of a May morning, bright and fresh and sparkling. This beginning of the rains is the spring of the tropical year, the trees are coming into fresh leaf, flowers are everywhere showing themselves. Among the brightest at this time were the gladiolus, scarlet, white, lilac, puce, lemon, and orange. No one in Yao land need fear to want flowers about Christmas. 
"We were now close to Mataka's villages, and slept in one of them on the night of the 8th of December, having made twentyseven full days of travelling, the remaining eleven being days and half-days of rest and provision-seeking. The approach to Mataka's country on this side is well marked by a mountain called Savinga, which shows from a distance a flat summit and a pointed one joined by a kind of saddle. We rounded a great mass of granite rising some five hundred feet nearly perpendicularly, and were immediately in cultivated land.

"The men preferred to rest the next day, but I was anxious to see the chief himself, so I compromised by paying native bearers to carry their loads. We stopped at midday at a village on the brow of a hill, where lived Nyenje, sister's son to Mataka, and, therefore, by Yao customs of inheritance, his next heir. He gave us a goat, and we revelled in abundance.

"The view from Nyenje's house is very fine; it looks down a broad valley, from five to ten miles wide, fringed by fantastic craggy hills, and studded with villages and towns, several of them with three or four thousand inhabitants. All these are Mataka's subjects.

"The morning after our arrival at Nyenje's, we were all refreshed and in good spirits, and started early for Mataka's own town, with flags flying, a small gong making its music, and every man's gun loaded, to fire in honour of the chief. Besides, the evening before they had all had their backs straightened-a necessary operation at the end of every job in Africa-by a present of a red cap each.

"We crossed two narrow valleys, and round the shoulder of a great hill came upon the broader one in which, in a town called Mwembe, Mataka has now for a good many years resided. One saw the effect of this prolonged residence in the more careful cultivation, and the utter absence of trees. The Mwembe valley is as bare as any part of England, and the great hills around are largely cleared. Everything here is planted in ridges, which enables the people to bury the grass and rubbish as a sort of manure, and prevents the plants from being stunted by the baking of the dry season, during which the clayey soil becomes dry and hard as a stone. 
"We were not destined, however, to make a dignified entrance into Mwembe, for a drizzling rain came on, and as we had to cross several spans of the main ridge, with steep descents and ascents, ending by the ascent into the town itself, the rain made the clay path so slippery that we slid and staggered on as best we could in sad disorder. However, we blazed away a good deal of powder, and the town turned out in force to look at us. It was a new thing to me to see a genuine town crowd in Africa. Livingstone reckoned about a thousand houses in Mwembe, and it has not since diminished. I could not count the houses myself, but I think there was probably quite as many as Livingstone stated.

"The people have made a curious compromise with their old custom of moving away from the place when any one dies. They build a new house close to the old one, and ridge up the clay and rubbish of the old walls into a small plantation of Indian corn. Every spare plot is planted, so that after the rains the town must look like a sea of green, with house-roofs floating upon it."

A steep road through the thickest part of the town led to Mataka's house, which stood in the midst of a large yard surrounded by trees. In the broad space under the eaves of the house there was a sort of earthen throne three steps high on one side of the door for the chief himself, and a lower bench on the other side for his visitors. There the Bishop was placed, and then Mataka came out and sat upon his throne. He understood Swahili, but would not talk it, preferring to use Chuma, himself a Yao, as an interpreter. He made the Bishop very welcome, and offered him the choice of two houses; and afterwards sent him presents of food and pombe. He professed to be quite willing to let missionaries settle at Mwembe, but afterwards got a little frightened at the idea of their doing so, and preferred that they should settle nearer the Lake Nyassa, at Losewa. This was not to be wondered at as he got most of his wealth by the sale of slaves, and he well knew the English to be the enemies of the slave-trade. He declared that he only sold criminals, but it was certain that he sold his own slaves, and, when he could get them, the people of 
Makanjila, his great enemy, whose territory was south of Mataka's kingdom, and who, though with less energy, was richer than Mataka, and possessed many more subjects.

The Bishop stayed at Mwembe about a fortnight, when the continual rains and the recollection of the rivers to be passed made him think that it was high time to return.

"I had explained our plans and wishes," says he, "as widely as possible, and spoken as I could about our great work. Some evidently believed not a word of what I said, some heard with more or less of interest, all promised me a welcome if I returned. I found that I could make myself understood very frequently in Yao, and that, though full of deficiencies, the collections for a handbook of the language printed for us by the Christian Knowledge Society was as a whole very correct and useful. Mataka's women guessed all the enigmas at the end, and brought their companions again and again to hear them.

"It seems to me morally certain that the Yaos will be Christians or Mohammedans before very long, and I think the question will turn a good deal upon which is the first to write and read their language. The Mohammedans have the advantage now, and we must work hard to win it from them. Makanjila has already adopted Mohammedanism and coast usages ; the enmity of Mataka with him makes his people more open to Christian teaching. The old man himself abhors Mohammedanism."

Having left part of his goods with Mataka, in case $\mathrm{Mr}$ James, of whose death he was of course unaware, and his party might yet arrive, the Bishop hoped to have gone down to the coast lightly burdened and very quickly, but his men, finding that he had but few burdens, bought such a quantity of tobacco for themselves that they were more heavily laden than before. The Yaos use their tobacco almost exclusively in the form of snuff, but in Zanzibar it is specially valued for chewing, and commands a higher price than any other sort. There is no legitimate commerce between the Yaos and the coast except in tobacco and bhang, and a very little ivory, the elephants being nearly all killed off. This want of other trade is probably 
the chief reason why the Yao chiefs cling so firmly to their slave traffic; the opening up of some new commerce would be the surest way of destroying the trade in human beings.

The final start from Mataka's villages was made on December 2 nd, and the Rovuma was reached on the rst of January. The river was unusually high, and overflowed all the adjacent lowlands; but it was crossed on January 7 th at a place where the river flows in one channel, and is in breadth and current like the Thames at Westminster when the tide has begun to run out strongly. Two days more brought the party to the Mwera forest.

"It rained now," says the Bishop, "nearly every night and a few days, and we rushed through the Mwera forest, making two days less than in going up, chased by thunder-storms, which generally burst upon us just before sunset, by which time we were hutted in and prepared for them.

"Here we saw some of the horrors of the slave-trade, as we were close behind a caravan which had left in each day's journey one or more of its number cruelly murdered by the roadside, and the very last day before reaching the villages we came upon a man lying in the path in the very act of dying of hunger and fatigue. He was far beyond all help, and we could only watch his last sighs.

"Surely if there can be a holy war it would be one against a traffic which bears such fruits as these. If we had the means to hire and feed some hundred or two of men, to clear and plant, and build, and defend themselves if necessary, I think this line of trade at least might be finally closed, but it would be madness to attempt force unless one had ample means, and at least the passive support of the English Government."

In his journey the Bishop met nine caravans representing from I 500 to 2000 slaves, and possibly some ro, 000 for the whole year.

On January I6th the party was again among the Mweras, for whom the Bishop confesses a great liking, and who are a simple, quiet people, scarcely touched at all by coast influence, but no stay was made among them, as food was scarce and rain plentiful; and on January 2 Ist the party walked again into 
Lindi, in very good condition, having been thirty-one days on the road from Mataka's, twenty-five of which were full days of marching, and the remaining six, days of resting and buying of food.

The Bishop's observations led him to conclude that the road he pursued required but little clearing to make it easy for a waggon. He heard, however, of a shorter route to the Rovuma from Lindi which was even more level, but the coast men did not use it for fear of Machemba, a Yao chief, who was said to be a bloodthirsty, treacherous captain of a band of robbers, and who had made the country south of Lindi harbour a tangled wilderness, and blocked up the way to the inland Makondes, a race which lies south of the Mweras, and occupies the coast country between Lindi and the Rovuma.

The country through which the Bishop passed has been the scene of terrible destruction during the last twenty years, and whole nations have practically disappeared. The Yaos are now in every sense the strongest in mind and body as well as in numbers. None of the tribes have a common head; but Mataka, Makanjila, and Mfonda, who is established at the outlet of the Shire, are really great chiefs.

The Mweras are even less united, every little group of huts being independent.

The Matambwes on the lower or middle Rovuma are almost overwhelmed by refugee Gindos, Dondes, Yaos, and Makuas.

Concluding the account of his remarkable journey-remarkable in the way it was undertaken and carried out, and remarkable also in its results - the Bishop says :- "Old traders say that the road from Kilwa to the Nyassa used to lie entirely through an inhabited country where food of all sorts was fabulously abundant. East of Kilwa lay the Gindos, and south of them the Mweras; east of both these the Dondes, and then, on the lower Rovuma, Matambwes, and on the upper and along the Lake, Yaos. South and east of the Lake, Nyassas, and east of them again the Bisas, who were ardent traders, and used to send down caravans of their own to Kilwa.

"The great disturbers of this state of things were the Maviti or Mazitu, a Zulu army sent on an unsuccessful expedition, 
which, instead of returning to be decimated, went north, and found a new home round the north end of the Nyassa, where they plundered and burnt in all directions, even sending an army against Kilwa itself, and for the time stopping all trade. They were not great slave-dealers, but used to cut off the left hand of such captives as they did not kill. I saw many were thus mutilated.

"It is said that during the suspension of trade, some people called Magwangwara, from near Lufiji, came to Kilwa to ask why no cloth now came to them, and being told of the Maviti, promised at once to clear them out of the way, which they did so effectually that the Maviti are no longer dreaded. But the Gwangwaras, having felt their power, became still worse destroyers than the Maviti had been, and all the more so because they found that slaves were valuable merchandise in the eyes of Kilwa men. Their custom is to incorporate the more likely of their captives into their own tribes, the rest they offer for sale, and if they cannot get a good price they kill them. The scattered remnants of the Gindos and Dondes were an easy prey, and for a time the Zanzibar market was full of Gindo slaves. The smaller Yao chiefs could offer but little resistance, and though the Gwangwaras have never ventured to cross a large river, or to attack a village in the mountains, they soon found they could easily cross the upper Rovuma in the dry season, and su the country to the north as well as that to the south of the river lay open to them. The few remains of the Gindos flee backward and forward as they hear of the approach of their dreaded enemies, and the few Dondes left have generally taken to the trade of thieving.

"The stoppage of the Kilwa slave-trade would take away the motive of these Gwangwara raids, and the existence of a city of refuge under men bold enough to give them two or three crushing defeats, would teach them not to treat their neighbours as cattle to be driven at their will. Badly handled, ill-made flint guns are not much better than old spears and shields, but a few modern rifles would soon teach them a different lesson. Now, however, strong thieves get gunpowder 
as the price of slaves, and the peaceable are deprived of their only means of defence.

"The coast trade itself, in anything like its present dimensions, seems to be scarcely twenty years old, corresponding, in fact, to the growth of Zanzibar as a centre of commerce. Yet it must have been once of great extent, or Kilwa could not have been the important city which the Portuguese found it.

"In the Yao language there are a few words which point to the old commercial relations with the coast, especially the name for coast people, which is merely the Arab name for Christians; this seems to show that at the coming of the Portuguese there was Arab influence enough among the Yaos to give them an Arab name. The trade died in their hands, and only in our own days is returning to its former importance. The same conclusion may be drawn from the vague acknowledgment of one God by all the nations between the great lakes and the sea. This is just the remnant of Mohammedan teaching which might be expected to survive, when that teaching was first forcibly suppressed at the fountain-head by a professed Christianity, and then allowed to wither away into forgetfulness, nothing really remaining except a distaste of visible idols.

"It is only on the young men of the present generation that Mohammedanism is beginning to exert a powerful influence, and this just in proportion as they are struggling into some kind of civilisation. It is therefore much more felt by the principal Yao chiefs than by the smaller, or by the less advanced Mweras."

The Bishop returned to Zanzibar early in February, having been detained some days at Lindi. We found that of his clerical staff only two remained, Mr. Randolph at Zanzibar, and Mr. Farler at Magila.

During his absence another death besides that of Mr. James had occurred. Miss Marsh, who had not long joined the Mission, and who was proving a most valuable worker amongst the girls, died of fever.

In the midst of the trouble caused by these deaths, $\mathrm{Mr}$. 
Farler came to Zanzibar very unwell, but after some weeks of rest and medical care was able to return to Magila.

The work of the Mission, under the direction of Mr. Randolph, had, nevertheless, flourished in all its branches, and with the arrival of Miss Allen, a daughter of Archdeacon Allen, hospital work was begun.

Industrial occupations were largely developed in 1866 . Laundries were established. at Kiungani and Mbweni. At the carpenter's shop the quantity of work done had greatly increased, and gardening operations were commenced.

In April the Sultan of Zanzibar, influenced thereto by the observations which the Bishop had made in his journey to Mataka's, and the vigorous efforts and representations of Dr. Kirk, the English consul, issued two proclamations, one forbidding the sending of slaves by land from Kilwa to the north, and the other prohibiting the bringing down of slaves from the Nyassa districts.

"These," remarked Bishop Steere, "are the first steps towards a complete destruction of slavery itself. We have printed these proclamations in Arabic, English, and Swahili for distribution, and our work (i.e., the printing) gets much praise from all quarters."

Some attempt at rebellion against these decrees was made at Kilwa by the people engaged in the slave-trade, but with the assistance of H.M.S. Thetis it was promptly suppressed, and the chief instigators of it were brought prisoners to Zanzibar. It must not, however, be supposed that the slave-trade was suppressed by these measures; it was diverted and made much more difficult, but many years may probably pass before the exportation of slaves from the coast will cease altogether.

It was not long before the Bishop's need of more clerical aid was supplied. In March the Rev. Chauncy Maples, accompanied by two laymen, Mr. C. Yorke and Mr. J. Williams, sailed for Zanzibar; and a few months afterwards Mr. W. P. Johnson, a graduate of University College, Oxford, who had gained distinction both in the schools and on the river, joined the Mission. Mr. Johnson was ordained soon after his arrival at Zanzibar. 
In June, in company with Mr. Maples, the Bishop paid another visit to Magila ; and found that a great deal of work had been carried on there. Mr. Farler had not only shown great zeal and wisdom in bringing the truths of our holy religion to bear upon the people committed to his care, but had developed a power of giving medical help to them, which had raised him high in their favour.

The Bishop and Mr. Maples reached Magila about eight o'clock on Trinity Sunday morning. They found all well, and arrangements just being made for morning service in the corridor round the house.

"The chapel," writes the Bishop, "is a small building, or rather room of corrugated iron, with a thatched roof overhead to protect it from the sun. The house is a large square mud and stud erection, standing in a sort of terrace made of large stones, which Mr. Midgley collected and arranged with a strength and skill which is very wonderful. How he moved some of the stones we could scarcely imagine. The deep eaves make a wide cool corridor all round. Here morning prayers were said, and I preached. In the afternoon the Dies Irce was sung as a Litany, and Francis Mabruki catechised and addressed the people.

"We had many and long talks about the work, and saw Mr. Farler's patients, who came in crowds daily for medicine and advice; and heard his classes, which he conducts with the help of Francis Mabruki and Acland Sehera. Mr. Farler is very skilful in employing them as interpreters and exponents, and so they themselves are immensely benefited by their share in the work.

"He pays daily visits to the neighbouring villages, and makes long excursions as he has opportunity. The reputation of his cures and his preaching has extended far and wide. He has been invited by a man of some power, a good half-day to the north, to establish a station among the villages under his influence; and the people at Umba, a frontier village towards the coast, have sent to ask for teachers. They have a Mohammedan, but they cannot understand his prayers, and would much prefer an English teacher. Among the catechumens are 
several men of importance, and all the rest are friendly. Persons coming from a distance often tell of the attention with which the whole country re rards him."

While at Magila the Bishop confirmed five lads from the school at Zanzibar, only one of the six who had come up with Mr. Farler having failed to satisfy him of his earnestness, and admitted eleven catechumens, who had all given up wearing charms and using spells, and were already known as followers of the Mission teaching.

One old man named Nyunga, the chief of a neighbouring village, who had been very much looked up to for his supposed knowledge of medicine and magic, or rather fetish and witchcraft, came and listened to Mr. Farler, and began to believe, and wished to be admitted as a catechumen, but he could not at the last moment dare to face what might befall him if he took off the charms which he had always worn. Nevertheless he continued to attend the classes and preachings, and at length told Mr. Farler that he would renounce all charms for himself. "But," said he, "you must let me go on making them for other people. I don't believe in them, but they do, and they bring me oxen, and goats, and presents, and listen to me, and I am a great man among them because they believe in them, and all this influence of mine will help you, you know." He was told that he must not play with his conscience and go on deceiving others when he had been undeceived himself. So he went away, but at last came back fully pre. pared to make the sacrifice required of him; for when he was asked if he renounced all spells and witchcraft, instead of merely answering that he did, he told all the people that they were worthless.

The sequel of this man's conversion had better be told here:-After one more lapse through the opposition of his children and relations, he was baptized by the name of Soloman, and continued most earnest in denouncing the folly of trusting to charms and of believing in witchcraft. All this has had so much effect upon the people that a large part of the population of Magila have become hearers or catechumens, 
and many are baptized, including one of Nyunga's sons, his wife, and all their children.

In $1878 \mathrm{Mr}$. Farler had to return to England on furlough, and from the account which he himself gave of his mission in a letter to Canon Liddon the following illustrations of his work are taken :-

"Before we had been working a year at Magila, our influence had extended far beyond our own country.

"One day two men came to see me from Bamba, a country two or three days' journey to the north of Magila, to inquire about our God. Their brother, who had been ill for many years, had lately had a relapse, and when they brought the medicine-man to beat the spirit-drum to frighten away the evil spirit which was supposed to be tormenting him, he protested, and said he only wanted to know the true God, which the white men preached. We told them the story of the Cross, and asked them to keep Sunday holy, and pray every day to God through Jesus Christ. They replied, 'It is good news, this love of God for us poor people; our sick brother will be very happy.'

"Shortly afterwards, a messenger came from the king of Usambara, whom I had never seen, saying that he and his half-brother the king of Ukalindi had been fighting since the death of Kimweri, their father, ten years ago; they were tired of war, and both wished for peace; but naturally distrusting each other, they did not know how to meet and arrange the terms of peace. They both trusted the missionary; and if I would come and meet them, my presence would be a guarantee against treachery on either side. I appointed to meet them at Masasa, a border town of Usambara. We arrived in the evening after a long day's walk, but, from the beauty and variety of the scenery and flora, a delightful one. On all sides towered the mountains from 3000 to 4000 feet above us, and dotted with trees to their very summits; down their sides dashed waterfalls sparkling in the sunlight, and strewing the air as though with diamond dust. Through the valleys rushed the rivers with waters clear and cold; and on their hanks were fields of yellow rice and golden maize. Here and 
there were villages embowered in graceful palm-trees; and everywhere we saw beautiful ferns, trees, and flowers, unknown to Europe. We found Masasa situated on the top of a high mountain; the view was magnificent, and the sharp mountain air was invigorating, while the scent from the blossoms of the numerous orange-trees was very sweet.

"Next morning the grand council was held. In a circle outside of it, great numbers of people assembled to know whether at last they were to have the blessing of peace. After a little conversation, I made a speech to the chiefs. I said that God must be very angry to see brother fighting with brother, and spoke about the wickedness of war and the misery it caused. The people shouted, 'True! most true!' After the terms of peace had been settled, the chiefs shook hands, and then every one sat down to a feast. Later, I preached to them of the life to come, and the love of God.

"Before leaving, Kibanga, the king of Usambara, asked us to send a mission to his people, and invited us to go a tour through the country with him, and select a suitable place for a mission station. I was obliged to tell him that we had neither the man to send, nor the funds to support a mission to his country. He is still ready to receive a missionary.

"At one time we were constantly annoyed by some Mohammedans who lived at a large frontier town called Umba, between us and the coast, in which they had built a mosque.

"As our people went backwards and forwards to the coast, these Mohammedans insulted them, and mocked at Christianity. We determined therefore to hold a three days' mission there. So we went and pitched our tent in the middle of the town, and announced our intention of staying there three days, and preaching to them in the evening. The old chief, who was very friendly, said we might do so ; but as it was the full moon, every one would be dancing, and he did not think we should have any one to listen to us.

"In the evening we lit a fire before the tent, and commenced by singing a hymn. This attracted a few people, and we preached to them on the immortality of the soul, the judgment, and the life to come. The numbers gradually 
increased, even the Mohammedans listened attentively, and after we had finished, several remained until eleven o'clock asking questions.

"The next evening many more attended, and we preached on the Fall and the Redemption. The statement that 'Christ is God,' created quite an uproar on the part of the Mohammedans, but the elders ordered them to be silent. At the end of the sermon many said they believed our words. Upon being asked whether they only said this with their mouths, or whether they believed it with their hearts, they replied, 'With our hearts.' A large number remained for several hours asking questions about the life of Jesus.

"On the last evening no dancers were left, all came to the preaching. The interest was intense, many people having come from other towns; for we had announced as the subject, 'A Contrast between the Lives of Jesus and Mahomet.' Whilst the evil and impure life of Mahomet was being contrasted with the holy and blessed life of Jesus, not a sound was heard. When we had finished, a man stepped forward and said, 'We became Mohammedans because we had no religion, and the beach people came and taught us theirs; but we don't like them, for they cheat us, and if Christianity is better than Islam we will follow it.'

"Acland Sehera, my young native catechist, and myselt remained until past midnight answering questions, for nearly the whole of the people had remained to hear more.

"The next morning, before leaving, the chief and principal men came to us and begged that we would send a teacher to live with them, and instruct them in the faith of Christ. One of our English laymen, Mr. Yorke, volunteered. At the present moment the mosque is in ruins, and near it stands a Christian church, where prayers and praises to our Saviour daily ascend, and where on Sundays a devout congregation assembles to hear the Word of God.

"Several Mohammedans have become Christians. In fact, our first two converts were Mohammedans, sons of a Swahili Arab father and a native mother. These young men had to undergo persecution whenever they met their father's relatives 
on the coast. They were called apostates, and threatened with imprisonment until they recanted. They both stood steadfast in the faith of Christ; and the younger, Laurence Kombo, boldly preached Christ to his people, and argued with such effect with the Mualim, or leader of the prayers, that the Mualim was silenced, and had to retire defeated, while, strange to say, the relatives of Laurence were even proud of his knowledge.

"Khatibu, one of the principal men, told me afterwards, 'That boy Kombo knows more of Islam, and the religion of Isa ibn Miriam, than our Mualim, and is evidently a Christian from conviction." "' 


\section{CHAPTER XIV.}

T $\mathrm{T}$ was not until the end of September (1876) that the Bishop 1 was able to take up the work connected with his expedition to the Nyassa country; then he ?;egan to make preparations for another journey with the view of finding a suitable position for some of the freed slaves living at Mbweni.

On the I6th of October he left Zanzibar, accompanied by the Rev. W. P. Johnson, Mr. Beardall, four of the old scholars from Kiungani, Chuma, seventy porters, and fifty-five of the Mbweni people, viz., thirty-one men and twenty-four women, including two girls who accompanied their mothers. Some of these last people were baptized, all had been under Christian instruction, and they had as native leaders John Almasi and Sarah Lozi, one of the best of the baptized couples.

Besides the necessary personal luggage, and food for the journey, the Bishop took with him five draught oxen, a donkey, and a cart that had been made in the Mission workshop. He carried on also towards its original destination the portable altar table taken out by Bishop Mackenzie, but left by him at Capetown, and which was brought on to the Zambesi and Zanzibar by Bishop Tozer. Captain Crohan of the Flying Fish kindly towed the dhow in which the Mission party had stowed themselves to Lindi, where they arrived on the $\mathrm{I} 8$ th.

It took nearly a week to hire the necessary additional men, to buy food and to get it prepared for use on the way, and to distribute the guns and axes and hoes, and so forth. Everybody from Mbweni had a hoe, and every man an axe, in view of the clearing that it would be necessary to do.

This was a very different party from that of the year before, when the Bishop's companions broke down, and the people of 
Lindi did all they could to hinder his journey. Now all seemed equal to the occasion, porters offered themselves in any numbers, and a caravan of nearly two hundred was formed.

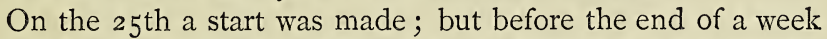
it was found necessary to leave the cart behind, for though the oxen pulled well, and the men worked well, the forest was so thick, and so matted together with old thorny creepers, that it would have taken months to clear a road through the first belt of woods, beyond which the way is clearer. So the animals only were taken on, to make sure whether the tsetse fly, whose bite is fatal to them, was in the path.

"I had satisfied myself," says the Bishop, "in my first journey, that there was an easier way through the hill range, and so we now followed up the line of a small river, the Ukeredi, which flows into Lindi harbour. We walked on for ten days through a famine-stricken country, and then emerged upon a district of plenty. On one of the most inland spans of the coast range, some eighteen hundred feet above the sea, lies a mountainous district called Masasi, well watered, fertile, untouched by war, which seemed to us all a paradise in comparison either with what we had passed, or with what lay beyond it. More than a hundred and fifty fowls and a great number of pigeons were killed in our camp the night of our arrival.

"Directly I got to Masasi I had a sort of deputation from the Mbweni people to say :- 'Here we are among our own people, here is no fear of war, here is food in plenty, here let us stay.'

"Not to decide rashly, I made all the inquiries I could about the road in front, and having satisfied myself that the famine before us would make a forward journey scarcely possible, I accepted this as the voice of God, and determined to plant the colony at Masasi.

"We found that our party was consuming food at a rate we should find it difficult to supply. We sent off, therefore, first the packages we had in charge for Livingstonia (the station of the Scotch Mission established at the south end of Lake Nyassa), and our present for Mataka, to keep alive an interest with him.

"A party was next sent to the coast to fetch up the fifty 
loads we had been obliged to leave behind. This reduced us to our Mbweni people and a small working party from among the porters, including a mason who had often worked for us in Zanzibar.

"I had a very interesting visitor the day after our arrival at Masasi. Very early in the morning a man came with a fowl, who said he had come to see us because long ago he had been set free by the English, and they treated him so well that when he heard of our arrival he took a fowl as the best thing at hand for a present, and set out to come and see us. As he was more at home in Yao than in Swahili, I called Chuma, and we made out that he had been in one of the parties set free by Dr. Livingstone and Bishop Mackenzie at the same time with Chuma himself. He had wandered about a good deal, and was now settled on the mountain. He afterwards brought his little daughter to see us, and said that as soon as he could, he would come and join us altogether.

"Next day came another man, who owed his freedom to our consulate at Zanzibar; so we had some friends already.

"We determined upon the site of a new station, and then get permission from a chief named Namkumba, who is a great smelter and worker in iron, to settle on the place we had chosen. We made presents of calico and brass wire and ornamental cloths to Namkumba and to a number of his relatives, and then began to clear.

"We marked out first a site for our own house on the top of a rising ground looking out in three directions between great rocky hills over the plain country beyond. Then we marked out a road forty feet wide, leading directly down to the water. Along each side of this road we marked out lots, fifty feet wide, running back to the rocks on either hand, so as to contain something less than half an acre each, and gave our people their choice of them. This was a trial for the temper of the men who had come up with us. We had not been altogether without a fear that they might scatter off among the native villages, or perhaps sit down and expect to be fed; but our fears vanished in a moment. They at once entered into the spirit of the village, and began without delay to build and 
to cultivate. In little more than a fortnight every couple had a house up on their allotment, a house for fowls, and perhaps for pigeons also; and before I left most of them had completely cleared and planted their home closes, and were at work in the adjoining forest clearing fresh ground for their chief grain crops.

"We wanted to make the church something better than our houses. The granitic rocks round us scaled off in such conveniently flat pieces, that the idea of building with them, using the earth from an old ant-hill for mortar, immediately occurred to us. Among our porters was a mason who had worked for us in Zanzibar, and he soon set to work. So we put up a chancel, or rather sanctuary, of stone, with a great thatched nave before it, and our village was then complete.

"Let us try to describe the spot as it is now. Our own house is laid out as an oblong, with circular ends, twenty feet wide, and seventy-six feet from end to end. One end, which commands no view, is walled round as a store-room. There are three bedrooms, each twelve feet by ten, and the other circular end is half open and used as a dining-room. A passage leads through to a back-yard and kitchen, and a large verandah, about forty feet by ten, is to serve as a public room in front.

"Standing in the verandah you look down a road, forty feet wide, to the water. This is about 500 yards long, and falls at first gently, but afterwards more rapidly. This is the High Street of the village, and the cottages lie in order on either side. Looking across the water the land rises again, and one can see a village on the slopes about a mile off. Still farther, rise two great mountains of granite blocks, with a sort of saddle between, over which a higher peak appears, probably rooo feet above us; the level of our house, so far as we could judge by the barometer, being about I 800 feet above the sea. The base of this great peak is about four miles away. Turning to the left, the clearings now enable us to look out (nearly to the east) over a wide plain, to the far-off coast ranges. Still farther to the left, our gardens are bounded by a well-wooded rocky ridge, about roo feet high, and per- 
haps 300 yards long, with a bold cliff to the eastward. Behind the house, to the south, is a wide opening, showing the great rocks near the Rovuma, some near and sharp, others fading away into distant shadows, the flat forest horizon bounding all. Due west is the grandest of all our rocksthree great masses, lying, as it seems, loosely one on another, each nearly a hundred feet thick, and broken masses beside them fringed with trees, all crowned by one huge block, enamelled with orange and grey lichen. The morning and evening effects on these great rocks are strikingly beautiful. Then a rather narrow cliff, shut in by broken rocks and trees, opens a view to the north-west of the endless forest, with its sea-like horizon. Some great single blocks, perhaps forty feet high, bound our gardens to the north, and then a glimpse, showing us the sides of the various summits of the mountain itself, brings us round to the door again.

"When the men came back from Lindi they brought us, as a present from the chief Arab there, a great many young plants of orange, lemon, mango, guava, and jack fruit-trees, besides some choice cocoa-nuts for planting. Thus we were able at once to fringe our roads with the best fruit-trees of the coast.

"I stayed a month at Masasi, till all matters had arranged themselves, and in returning to the coast I had the opportunity of opening a fresh work, by which I hope we may hereafter supply our central schools with the best possible material for raising up our future native ministry. Several of the sons of chiefs along the road asked me to take them down to Zanzibar, to see something of our work, and learn something of what we had to teach. They came down, and they were very attentive, and learnt much in a short time. Two of them did us good service on their return; for when I had gone down, the neighbouring chiefs had been wondering much among themselves what could have induced us to come and settle in the country; and some suggested that I was to return soon with soldiers and enslave them. Then some said,-Let us burn their village before they get too strong. Just at this moment the two young men came back, and not only did they give up 
all thought of burning our houses, but they sent down a fresh party of pupils."

When the Bishop reached Lindi, on his way back to Zanzibar, he was greatly fatigued, and was attacked by fever. While still suffering, and really in great danger, he left Lindi in a dhow, and was four days in getting to Kilwa, where, happily, he fell in with H.M.S. Philomel, and was at once taken on board by her commander, Captain Boys, from whom he received such assiduous care and attention, that when he arrived at Zanzibar the worst danger was passed. But as any attempt to engage in the work of the Mission brought on a fresh attack of fever, he yielded to the advice of the medical authorities at Zanzibar, and left for England in February 1877. He arrived in England, after a short sojourn by the way at Algiers, in April, and was so much invigorated by the voyage that he soon began to speak and preach for the Mission, in which employment he was almost constantly engaged until he returned to Africa in September.

During his stay in England the Bishop was able to recruit his staff of workers, but not to the extent required. He was preceded in July by the Rev. F. N. Hodgson and his wife, Miss M. Hinton, and Mr. F. J. Williams, a student from St. Boniface, Warminster; he was accompanied by Miss Thackeray, and followed in October by Mr. C. S. Newham and Mr. H. Woodward, who had done a period of service at Zanzibar, and returned after a necessary rest and change in England.

The Bishop arrived at Zanzibar early in November, and the Rev. E. S. H. Randolph, whose health had been sorely tried by the responsibility of the superintendence of the Mission during his absence, soon after sailed for England.

Under the care and management of Mr. Randoiph, there had been no falling off from the high standard of work which Bishop Steere maintained at Zanzibar; and it is a gratifying testimony of the regard in which the Mission was held, that when it was known in Zanzibar that the Mission was short of money, the Europeans of the town subscribed $£_{\mathrm{I} 2 \mathrm{O}}$, and sent it with a note to the effect that it was offered lest, in face of the wants of those dependent upon them, the missionaries might 
be led to stint themselves of necessaries and comforts essential to their own health.

Among the events of the year, besides those already mentioned, there are some that should be recorded as illustrating the position and growth of the work of the Mission.

I. On March 26th the London's boats came in with a batch of one hundred and sixty-five slaves captured off Pemba. Mr. Randolph felt that it was grievous to refuse them, but fifty were as many as the accommodation and the means of the Mission could allow him to receive, and he begged for Yaos and Nyassas only. Fresh buildings had to be put up for these people at Mbweni.

The number of natives then under the charge of the Mission was $4 \mathrm{r} 9$, about half of whom were baptized, and $\mathrm{r} 70$ of whom had been received as children.

2. Nurse Jones died at the infirmary. She had been ailing for some time, but sank suddenly at last, and was taken to her rest on April I Ith. She was a great loss to the Mission. And as Nurse Durham left shortly after for England, and Miss Allen was unable to carry on the hospital by herself, it was closed to the townspeople till the arrival of Miss Hinton in August.

In the meantime Miss Allen commenced a sort of Zenana Mission to the Mohammedan ladies of the town, which the Bishop regards as the foundation of a great work.

3. A party of nine men came down to Zanzibar from Mataka, the Yao chief, as an embassage to ask for the missionary whom Bishop Steere had promised. He had heard of the establishment of the Masasi station the previous autumn, and was much disappointed at the party not having come on to his own country, so he had sent these men as an escort, that there might no longer be any excuse for delay.

They were entertained at the Mission some weeks, and then the Rev. C. Maples and Mr. J. Williams, with a party of seventeen natives who were going to reinforce the station at Masasi, accompanied them thus far on their way back.

In the narrative of his journey to Masasi, Mr. Maples dwells on the practicability of a mission being established at Lindi 
itself. The Arabs are few in number, and devout men, for the most part, in their own religion, and they are favourably disposed towards the English, not misunderstanding our motives in planting mission stations in the country. They seem to be singularly free from bigotry, and it is probable that a missionary who did not denounce indiscriminately all that Mohammed did and taught, would meet with a ready hearing at Lindi, when he set before the people the infinite purity and holiness and love of Jesus.

Mr. Maples thus describes his arrival at Masasi :- "It was soon sufficiently evident that we were arriving. The gun-shots fired in salute came echoing down to us amongst the hills, and our own in answer mingling with the noise, told us to keep a sharp look-out for two well-known white faces not yet upon the scene. But now upon the path came rushing to greet us one well-known form after another; we were shaking hands with and making eager inquiries of William and Zamedi and Mark, and then came the Mbweni men and their wives, all gay in their bright clothes and beads donned for the occasion. The path now took a sharp turn, and there, just down by the water, stood Johnson and Beardall patiently waiting for us. We were soon grasping their hands, and as we walked up the spacious road which leads to the mission-house itself, we eagerly exchanged the news of the past nine months. All had gone on well since the Bishop's departure in December. The people had behaved in quite an exemplary manner, while the natives had learned to trust the new-comers and to show other signs of friendship.

"I could not admire too much all that had been done in so short a time, the substantial buildings that had been begun and completed, the extent of ground that was under cultivation, the sprouting fruit-trees, the flourishing cassava, and above all, the pretty little church with its stone chancel-the first church in these parts, and for a distance round which can be counted by thousands of miles. But the place itself and the surrounding country are like a scene of enchantment. Certainly we are situated on a most glorious spot, where nature has been lavish of her beauties, and where the earth with a loud voice showeth His handiwork." 
4. Mr. Beardall took advantage of Mr. Maples' arrival to go on to Mwembe with Chuma, who, with some of the Mission porters, accompanied Mataka's people to their destination. He found Mataka ill, and that the slave-trade in his country was as vigorous as ever. The traffic coastwise had been to a great extent stopped, but large caravans were being despatched westwards into the Beisa country, where a ready market was, found, ivory being given in exchange for slaves.

5. Mr. Beardall reached Zanzibar early in November, and shortly afterwards sailed for England, having completed the term of service for which he volunteered. In him the Mission lost an admirable lay superintendent, first at Mbweni, and afterwards at Masasi, where his judgment, discretion, and hold upon the Mbweni settlers did much to guide the new Christian settlement through the difficulties and trials of its first year.

6. The Rev. W. P. Johnson, who had been spiritually in charge of Masasi till Mr. Maples arrived, was compelled by serious illness to go down to Zanzibar in November, where careful nursing and good diet did much to restore him to his former state of health.

7. Masasi was left in the care of the Rev. C. Maples and Mr. J. Williams, who early in November made a tour of over 200 miles in the vicinity, with the threefold cbject of getting boys for their school, making friends with that much-dreaded and powerful chieftain Machemba, and obtaining permission to have a mission station at Newala, a large populated district about fifty miles from Masasi, that was under a well-disposed Yao chief, named Matola.

They succeeded beyond their expectations. Machemba not only received them gladly, but allowed them to take back to Masasi two of his most promising slave-boys and his own son for the purpose of being taught in the school, and Matola freely gave them permission to build, open a school, and settle a party from Mbweni at Newala.

"Matola," wrote Mr. Maples, "saw the advantage of a European living with him as an almost certain safeguard against the Wagindo, and generally as likely to bring to an end the petty warfare that goes on around him; but I had a 
long talk with him on the main subject of our sojourn in Africa, and told him plainly what I wanted; and what he said afterwards made me full of joy, for it seemed to give such hope of his own future conversion."

8. On Easter Monday it was Mr. Farler's privilege to baptize at Magila fourteen converts-twelve men and two women. The baptism took place in the river, which is about a quarter of a mile distant from the church.

"There was," says Mr. Farler, "a solemnity about our act which communicated itself to the spectators. Many strangers who had come for the great market next day, stood on the opposite bank and were very talkative at first, but they soon became quiet. When the baptisms were finished I came up out of the river, and we returned in procession, singing Hymn 208, Ancient and Modern :-

'O Father, Thou who hast created all,'

and other hymns. (The whole of the office, with the hymns and addresses, were in Swahili.) On arriving in the church the neophytes were received, one by one, into the visible body of the Church of God. At the end of the office Ackland Sehera exhorted them with great earnestness to stand firm to their vow, and fight the good fight of faith.

"At noon all sat down to a feast, and as they were fasting they thoroughly enjoyed it. Amongst them there are two sons of old Kimweri, the chief who welcomed Mr. Alington years ago, Mkande being the family name. When shall we be able to send missions to the countries ruled over by their brothers? Kibanga has asked for one for Usambara, and I don't think Símboja would decline one for Vuga.

"Phillips is working well at Umba, and has the natives under Christian instruction. These, with my people here, make over one hundred native Africans now receiving Christian teaching at the Magila station. Now I have come to the conclusion that I could not have done this in such a short time but fur the work of Fraser and others; for although there was nothing to show for their work, no converts to be counted, yet still a 
most useful work had been done in familiarising the people with our presence and object. So that when I arrived here, I was received by many as an old friend rather than as a stranger.

"Our English friends must not think that because no con verts can be counted for the first years of a mission, that it is a failure, or that no work is being done. I intend next week to go to Bamba; the people have sent so many times to beg me to come and preach to them. It is a beautiful country, very mountainous and rugged. I think the rest and change will do me good. From thence I shall try and penetrate into the Wadigo country, if they will receive me, and then back to Magila, through Tanga, Morongo, and Umba."

Later on in the year Mr. Farler held a most successful harvest thanksgiving. The district had suffered much from the failure of the early summer crops, and the ingathering of the autumn harvest afforded him a good opportunity for inviting the people to return thanks to God, the great giver of all good things, instead of to evil spirits, to whom they had been wont to offer first-fruits. Many accepted the invitation; and in the course of the next few days seven men who had been present came forward and asked for Christian instruction, with a view to baptism.

Towards the end of September, Dr. Kirk and Captain Wharton, R.N., visited Magila, and were so much pleased with what they saw, that the latter gave a harmonium for the use of the Mission and $£ 20$ towards the building of a permanent church.

9. Mr. Hodgson and his party arrived at Zanzibar in time for the anniversary of the Mission, when there were nine baptisms, and shortly afterwards the Rev. F. Capel left for India, having handed over to Mr. and Mrs. Hodgson the girls' school at Mbweni, of which he had been in charge for a year and a half. For nine years Mr. Capel acted as Honorary Organising Secretary for the Mission in England. In 1875 , as previously mentioned, he visited Zanzibar, and in the following year he resigned his secretaryship, and returned to take a more direct share in the work he had so long striven to uphold.

ro. The Bishop signalised Christmas Day by having a service in the yet roofless church in the old slave market, 
concerning which he wrote:- "A considerable number of townspeople came to listen; I preached to them on the great event of the day, and strangers listened most attentively. One felt the size of the church when about two hundred of us were packed into the shady side. The canticles and the hymns went gloriously. The whole was in Swahili. One could not but think of the first Christmas Day, when Captain Prideaux would not let me speak to the people for fear of a riot amongst the Mohammedans." 


\section{CHAPTER XV.}

THE Mission has now, at the close of $188 \mathrm{I}$, four great fields 1 of labour, viz., the Island of Zanzibar, the Usambara country, Masasi on the Rovuma, with the adjacent districts, and Mwembe, the capital of the Yaos or Ajawa.

I. The various operations of the Mission at Zanzibar include a girls' school, a girls' infant school, a farm, and a settlement for adults (freed slaves) at Mbweni; a boys' school at Kiungani; and a church, an hospital, a school for the children of the townspeople, and a Zenana mission to Mohammedan ladies at Mkunazini, or the old slave-market.

The original mission-house has been given up.

2. "Mbweni," says the Rev. F. R. Hodgson, "is certainly a very beautiful spot, planted out all over, as it is, with young cocoa-nut, clove, and other useful trees, with grass growing between them pasturing a herd of oxen.

"The girls' school at Mbweni is a large flat-roofed stone house, from which there is a look-out through palms and bananas to the sea. The rooms are long but narrow, as is usually the case at Zanzibar, because of the shortness of the native timber.

"The day is begun with service in the little chapel at 6.30 . At seven o'clock there is breakfast, all in one room, the Europeans sitting at the high table at one end, and the girls at two very long ones.

"After breakfast the girls go off to their different tasks of house-work; some to make the beds and sweep the dormitories, some to prepare the hall for school, some to the kitchen. At nine o'clock they go into school till $\mathrm{I} 2.3 \mathrm{O}$, with a quarte1 
of an hour's run at I0.30. The under-mistress and three monitors are all natives who have been rescued from slavery.

"There are thirty-seven boarders of all ages and sizes, some quite little things, and some almost of marriageable age, according as they have come from the slave dhows. This makes it rather hard to maintain discipline, and some of the bigger girls are gradually taken out of school if they show no aptitude for learning, whilst especial attention is given to the brighter and smaller ones, some of whom it is hoped may some day serve as teachers for mainland schools.

"Then there are twenty scholars, mostly children of the Christian farm-people, and a few heathen from the neighbouring villages.

"At 12.30 comes dinner; after which the names are called over, and the girls go down to bathe if the tide serves; if not, they bathe before morning chapel. At 2 they go into school again till 4.30. Supper for all comes at 6.30. Evening service at 7.20 , and then to bed. Saturday of course is a whole holiday."

Concerning the infant school for girls, Miss Thackeray writes :- "For several months I had a small class of day scholars on the landing outside the schoolroom door, the threshold of a doorway serving as a seat for the teacher, and the children sitting on the ground. However, when the numbers began to increase, they got beyond this not very magnificent accommodation, and I thought the best plan was to make a move into the corridor below the schoolroom, and try to get up a separate infant school, which, finding the Bishop approved, I did. We have now about twenty scholars in this school, who are taught chiefly by one of the native pupilteachers, with a little help and a good deal of superintendence from our native mistress, Kate Kadamweli, and myself. The corridor where they are taught is just at the foot of the schoolroom stairs, so it is easy for me to go up and down and look after both; and as it is my great object to make the Mbweni school a training-place for teachers, I am very glad to have an infant department attached to it." 
Concerning the settlement for the adult freed slaves, the Rev. S. Randolph writes :-

"We begin work here in this village of freed slaves at 6 A.M., when we all meet for prayers, and immediately after that the hiring of day-labourers commences by giving out tin tickets, which are worth so much when presented at the end of the day. The carts are then brought out, loaded, and despatched to town; and when this is all done, then I am free to go into the house for school, or reading, or doctoring, or anything else that comes to hand. With all kinds of interruption I stay in the house till 4 P.M., when once more to horse and superintend the last hour of work, and see what has been done. At 5 p.M. a bell rings, work stops, I tie up my horse to a tree, and go in with some of the people for the prayers which end the day's work-short and simple, and to which they all respond. Later in the evening there is a service for the more advanced Christians ; regular evening prayer in Swahili.

"I have often in England spoken of Mbweni, the freed slave village, its Christian pattern, i.e., the outward form, church, school, working days, and its Sundays, all calculated to represent to the mind of the individual a life better than the one he has lived before, and now I find myself set here to fill in the picture.

"During the last year a sufficient nucleus has been formed of good simple Christians, to justify the hope that it will not be in vain that the attempt is made, and the idea be realised of a village outwardly and inwardly Christian in the very heart of the misery and vice for which East Africa is famous."

There are upwards of one hundred married couples with nearly fifty children at Mbweni, and nearly fifty unmarried people. All these were taken from the slave dhows by English cruisers. Of the above, fifty adults are baptized, each one having had some months of careful Christian instruction, and fifty-four others are catechumens. A permanent stone church is being built at Mbweni.

Concerning the boys' school at Kiungani the Bishop reports favourably. The last examination showed a great improvement upon that of the previous year, and the tone of the boys" answers was healthy. 
There are nearly one hundred boys here who are taught reading and writing and arithmetic in Swahili. The most promising boys are taught English, and by degrees are made pupil-teachers, teachers, catechists, readers, and sub-deacons. One of the first five given to Bishop Tozer, John Swedi, has been admitted to holy orders, as deacon. For those boys who show no capacity for learning, there are various workshops, where English mechanics teach them useful trades.

The great event connected with this school was the ordination of John Swedi, which took place on Trinity Sunday, I879. The chief portion of his probation was spent in Zanzibar and at Mbweni, where he made himself both respected and beloved by the freed slaves. When such were first brought in, it was John Swedi's business to receive them, and to make them understand by word and deed the difference between their condition there and that which seemed to await them when they were in the hands of the slave-dealers. The settling down of these new-comers, and the providing them with food and shelter, was always his work, and he attended to their wants in a way which sometimes entailed great self-denial on his part. $\mathrm{He}$ constituted himself at once doctor and nurse in the care of many who were ill ; and when the time came for him to go to Masasi, where since his ordination he has principally worked, the sick lamented his departure with tears. It was remarked, however, that when he went away there were but very few who came to say a last "good bye ;" and when one of the missionaries expressed some surprise at this, the answer given was, that the "good-bye" had been said the day before, and they would not come out to see him leave, for they could not bear it.

The church erected on the site of the old slave-market has been in regular use since Christmas I880. It is a handsome building, capable of holding about rooo persons. There needs that much more should be done to it,- the great arch of the roof is to be covered with sheet zinc, but at present it is only thatched, and the fittings and adornment of the interior are far from complete.

The services are daily Matins and Evensong, with an address 
on Friday evenings in Swahili, and on Sundays a celebration of the holy communion in the early morning whenever the Bishop is not celebrating elsewhere, Matins with sermon in Swahili, and a Litany and catechising, also in Swahili, in the afternoon. The congregations are frequently large, an'd as an illustration of the effect which is being produced by the public services held in this church, Dr. Kirk, the Consul, when passing through the town on one occasion, heard a number of the natives discussing the doctrine of the holy Trinity with a good deal of intelligence and interest, and discovered that they had been to the church.

It is the great aim and desire of the Bishop to make the old slave-market in every way the centre of a living Christianity, and that round the church, hospital, and schools there should grow up a Christian quarter of the town, that houses should be built that may be let to old pupils of the Mission who are now engaged in various trades in the town, for there is an increasing number of such who would readily pay a fair rent for them. Many of these old pupils have been exposed to great temptations because of their faith; they have been unable to get lodgings near the church, and have been obliged to live amongst those who do all in their power to lead them astray.

In furtherance of this aim, sites for houses have been purchased, and some houses have been built, and are occupied by converts who are thus protected from persecution and saved from temptations to which they would otherwise be exposed. Concerning this feature of his work the Bishop says :- "It touches our very existence here. It is forming a parish round our church; and what is a church without a parish ?"

In March I 878 Mr. Farler came down from the Usambara country on his way home for a well-earned rest. He left behind him as the result of three and a half years' labour the three stations of Magila, Umba, and Pambili ; a body of native Christians, and a considerable number of catechumens.

The missionaries had won the confidence and affection of the people. They were regarded as the protectors of the persecuted, the refuge of the oppressed, the healers of the sick, 
and the dispensers of good in every form. They not only possessed but they used the power of mitigating sentences of death for petty crimes. They had opened a market for Manchester goods, and had introduced Indian coinage in the place of beads, \&c. They had created a desire for a higher standard of social life amongst the natives, which had led to an export trade of grain, in order that the means to enable them to live up to that standard might be obtained. They had, in fact, kept before them the object which the Universities' Mission originally had in view, and had done much to realise it.

The surrounding chiefs, seeing the improvement in the outward condition of the Wabondeis, the people amongst whom the missionaries laboured, desired teachers for themselves; and even the renowned Mirambo, the king of the Unyamwezi, who is said to have at command an armed force of 40,000 men, and who has again and again successfully resisted the attacks of the Arabs at Unyanyembe, offered to support a missionary if one were sent to him, and promised to do his best to introduce Christianity amongst his people.

The absence of Mr. Farler was a very severe test of the stability of his work. The stations were left in the charge of a young deacon, the Rev. O. Phillips, a lay-reader, Mr. Yorke, and the native catechists, Ackland Sehera, Preston Mabruki, and Arthur Solongo. For ten months they were without a priest, and consequently without a celebration of the holy communion. It is not therefore to be wondered at that there were some backsliders, and that the classes were not so largely attended; but no considerable loss was sustained, and at Umba, which was under the care of Mr. Yorke, much progress was made.

In February 1879 the Rev. P. Johnson went up to Magila, and his visit of nine weeks did much good in many ways. $\mathrm{He}$ was indefatigable in looking up every Christian and catechumen, so that classes and church were again well attended. He went about at all times and in all weathers to the neighbouring villages, and he preached to the people on market-days. Whenever he heard the "pepo drum" at night, he went to the house where it was used and endeavoured to show the people the folly of their proceedings. The 
"pepo drum," be it said, is used in connection with cases of so-called possession by evil spirits. When any one is supposed to be thus affected, and various forms of illness are attributed to this cause, the medicine-man brings his drum and beats it before the patient. The pepo (evil spirit) is thought to come out of his victim in order to listen to the drum, and the drumming is continued by one and another, until the pepo forgets, it is said, out of whom he came, and flees away, or takes refuge in the drum and is carried off by the medicine-man.

The superstitions of the Africans have a powerful hold upon them, and even among the converts it is not an unusual thing for some of them to resort in times of difficulty and sickness to practices connected with their old heathenish beliefs. It would be remarkable if it were not so. Nevertheless, as the years pass, they will not less surely than other races emancipate themselves from their influence.

In October 1879 a great alarm was caused at Magila by a raid of the Masai, a tribe living farther inland, on the coast people, because the latter had killed the Masai king's son. Their revenge was sanguinary, for they killed over two hundred people.

Daudi, the head porter of Magila, was at that time on his way up from Zanzibar with letters, stores, and money, and his bearers, thinking that the Masai were upon them, threw their burdens to the ground and fled, consequently everything was lost.

The stations, however, were not molested, though communications were for a time cut off, and supplies ran very low.

On his return to Zanzibar, it having become clear that the church in Usambara country should have a recognised head, the Rev. J. P. Farler was appointed Archdeacon of Magila, which place he arrived at on November $3 \mathrm{rd}, 1879$.

On St. Andrew's Day he reopened the church at Umba, which, owing to increasing congregations, had been enlarged to nearly twice its original size.

On December 2nd, Mr. Yorke, who had been ordained deacon, reported:- "I have had many invitations from a 
neighbouring chief named Sehira to go and teach him, and last week he came himself and reproached me for so long delaying to come; so on Thursday we started, and after a walk of about two hours reached Zunga, the chief town of the district.

"Sehira called his people together, and I preached to them on the Fall and the Redemption. They then asked for a teacher to live with them. I said none could live with them, as we English were so few in the land, and I had already built at Umba, but I would come from time to time to visit them. They saw the force of what I said, but still wanted a resident teacher. So I told them that I would ask Archdeacon Farler to send a black teacher, but that he could only come on condition that they built him a house and gave him food. To this, after again expressing a wish for an English teacher, they consented, and Sehira said that he much wanted to be taught about God, and that when a teacher came all his children should also be taught."

Mr. Yorke adds:- " This is a good beginning, and I do hope we shall be able to find some one to send. Besides Zunga, there are eleven other towns in this district. The water is very good, and much more plentiful than at Umba."

This was the last message of the writer to the church, for soon after it was written, Charles Yorke, one of the most lovable, and certainly the most successful, of the younger members of the Mission, was called to his rest. He had not been well during the latter part of November, and spent the greater part of December at Magila, where he so far recovered that he was permitted to return to Umba two days after Christmas. It would seem that in his anxiety' to arrive there he pressed on through the heat of the day, and exposure to the sun produced a return of fever in an aggravated form. He died on the evening of the festival of the Epiphany,- the first clergyman in the service of the Mission who had died on the mainland since the death of the Rev. H. C. Scudamore at Chibisa's.

At the present time the stations in the Usambara country are Magila, Umba, and four new sub-stations at Mfunti, Mdili, $\mathrm{K}$ wamagoda, and Lunguza, which are all within fifteen miles 
of Magila or Umba, and are served by resident native readers under the supervision of European clergy. The number of natives that have been baptized is over one hundred and fifty, and new converts are constantly coming in and being admitted as catechumens.

Nevertheless the good work here does not proceed without many lets and hindrances. In March I880, the Rev. E. H. Sayers, who had been working some time in Magila and its neighbourhood, was seized with a violent attack of fever and jaundice, and carried down to Zanzibar in a dangerous condition, where it was thought necessary that he should without delay return to England.

At the close of $\mathbf{I} 880$ another difficulty presented itself. A serious political complication arose amongst the native chiefs, and an armed party marched to Magila and ordered Archdeacon Farler to leave the country, or at least not to teach any more, which, of course, he refused to do ; so they contented themselves with stopping all his building operations, and for a time cutting off his communication with the coast. But such trials as these are inevitable. Moreover, it is not to be expected that no opposition will be offered by the fanatical adherents of the old condition of things when they find that their faith is being successfully assailed and their power sapped. Such opposition, however, is a tribute paid to the advantageous position gained by the Church.

Mr. Woodward, who succeeded Mr. Yorke at Umba, incidentally alludes to an attempt at opposition that might have been serious, had not the missionaries gained the confidence and good-will of the inhabitants. He says :-

"An Arab who had been away hunting three years returned, and having taken offence said he would pull down the bell if he heard it ringing, and the church too, for it interrupted his view. The old chief Semkali heard of this, and said the bell was to be rung as much as we liked, and went into the church to ring it himself, but he could not find how to do it. Eventually the Arab had to humble himself in a way which must have gone much against the grain. We found out that he was simply a freed slave, and had received his paper of freedom 
from a former British Consul. Directly this was known he was ready to do anything; from being a somebody he became a nobody, and could find none to aid him in his design of rebuilding the mosque."

At the beginning of I88 I a mission-house at Kaule was burnt down, involving a considerable destruction of Mission property, and exposing the missionaries in charge, Mr. and Mrs. Williams, to much loss and discomfort.

Soon after this fire the Bishop came to the conclusion that he should now take steps to plant a mission in the Zaramo country, which he himself had visited some time before, and he selected Mr. and Mrs. Williams for this venture. But while Mr. Williams was away in order to find a suitable site for a station, and to build a house in the country that was to be his sphere of work, Mrs. Williams was taken ill at Zanzibar, and died. She was a most effective worker, and the first lady connected with the Mission that had been personally engaged in the efforts that are being made to speed the gospel on the mainland.

With reference to the work of the Mission at Magila, the Bishop says it is the one "which has hitherto been the most successful in forming a real native church, and it has developed into its present form since Mr. Farler has taken charge of it."

Masasi, in the Rovuma district, is about 400 miles south of Zanzibar, and 130 miles inland on the road from Lindi to the Lake Nyassa. It will be remembered that the first detachment of freed slaves was settled there in 1876 . For some time after their arrival at Masasi these people worked for the mission for three days in each week in return for a daily allowance of food. On the other working days they employed themselves in their own gardens, and gradually brought many acres of forest land under cultivation. In course of time they were able to provide for themselves from the produce of their own gardens, and the daily rations were discontinued. When in need of clothes or anything else that they cannot otherwise procure they work for the Mission, there being always some building, or clearing, or planting to be done. Their wages are 
paid either in money or in cloth. The number of people at Masasi is about 250, and most of the adults are married.

The comparative healthiness of Masasi has been clearly proved. Fever is of rare occurrence, the rate of mortality is very low, and no epidemic or severe sickness has been known there. The Europeans who have lived there agree in thinking it far more healthy than Zanzibar, and believe it to be as free from malaria as any place that can be found in East Central Africa.

The fertility of the soil at Masasi seems to be extraordinary. Cassava grows to an unusual size, and almost every cereal and vegetable common to tropical Africa flourishes abundantly. The rice, maize, and millet grown there have the reputation of being superior to anything of the kind grown in the neighbouring country.

For the first nine months of its existence the freed-slave village at Masasi was placed under the care of the Rev. W. P. Johnson, then in deacon's orders, and Mr. Beardall, a layman. Of the original sixty natives who were taken there, only three of them were baptized, and Mr. Johnson's first care was to provide regular Christian instruction and worship for the village. Many of the people had been but a short time in the Mission before they left Zanzibar, and were very imperfectly acquainted with Swahili, consequently there was much to be done before they could be admitted into the catechumens' class. They were, however, instructed in the simple truths of the Gospel by the aid of an interpreter, and exhorted, though not compelled, to attend the daily religious services.

At the same time a foundation for future work amongst the Yaos was laid by the study of the Yao language, in which Mr. Johnson made, such progress, that before a year had passed he was able to preach to the people of a Yao village close by in their own tongue.

In August 1877, the Revs. C. Maples and Mr. J. Williams took the places of the Rev. W. P. Johnson, who was obliged to return to Zanzibar on account of ill health, and of Mr. Beardall, whose term of service with the Mission had expired.

In April 1878 the Rev. W. Clarke started from Zanzibar 
with a party of forty people from Mbweni to occupy the newly planted station at Newala on the Rovuma, about sixty miles distant from Masasi. With him went back three boys, sons of chieftains near Masasi, who had been in the schools of Zanzibar for some time.

Mr. Clarke and his party were hospitably received by all the chiefs on the route, more than one of whom wished that their sons might go down to the Mission at Zanzibar on the first opportunity. After a three weeks' stay at Masasi, the journey was made to Newala, where Mr. Clarke and his companions were heartily welcomed by Matola, the chief. Finding that the site offered at Newala was unsuitable, being too far away from water, they selected another between that place and Kilonda. This station lies moderately high, has good water near at hand, and is in the midst of a well-peopled district, close to the lower road from the Nyassa to the coast. The natives are Makuas and Yaos, the former predominating. House-building was proceeded with without delay, and Matola built a hut for his four sons to live in, under the charge of one of his wives, that they might have the instruction of the missionaries.

On Whitsunday I $878 \mathrm{Mr}$. Maples baptized eight men and eight women at Masasi ; and he thus reports of them and his work generally some time afterwards :-

"The behaviour of the newly baptized is really excellent. One seems to see in them every outward sign of the inward regeneration. Their baptism has had a great effect upon many in the village, who are all looking forward to becoming catechumens, and I may tell you joyfully that really the people are improving.

"The new nakoas (overseers) are most useful in bringing to light the evil that goes on, and so from day to day the bad people are driven more and more into a corner, and wickedness can certainly no longer triumph in our midst. Yakobo continues steady and useful to a degree; never in all my life have I had any one doing work under me who has done it so thoroughly, satisfactorily, and well as he; if his influence in the village cannot strictly be called spiritual, it is at least a very high moral influence for which I cannot be too thankful; 
and if we have been able as yet to do little spiritually for our neighbours, we have made great friends with most of the chieftains, especially the Makuas, and this is certainly something. Our expenses now are very small; we have any amount of cloth, and very little in the way of wants to spend it on, as all our people are now self-supported. I feel being without flour or any substitute for bread rather a trial. I do the greater part of my own cooking myself, and am expert at making rice cakes."

In July i $878 \mathrm{Mr}$. J. Williams was compelled to go down to Zanzibar for change of air, and from that time till the middle of November, Mr. Maples was the only European at Masasi, though occasionally Mr. Clarke came over from Newala.

It is impossible to give details of the work of these good missionaries, but a letter written October 8th, I878, by Mr. Clarke, will serve to show the character of their influence in the land. He says :-

"On Friday last I left here (Kilonda), by Mr. Maples' request, to attend a meeting of the Maviti, Makuas, and Seyed Kanghash's agents on the Rovuma, and returned to-day. I am glad to say we have been able to arrange matters satisfactorily, to overcome the difficulties of the Seyed's agents, and to establish a basis of peace between the Maviti and the Makuas.

"There were about sixty Maviti present, and I suppose one hundred Makuas. The Maviti chiefs were Mkumba of Mchichira, Leosi, and Mkuwra; the Makuas, Mawa, chief of Newala district, Mjorumbi, Chimaluja, and Matola, as representing this district.

"Peace was agreed upon between the Maviti and Makuas, and they shook hands, \&c., \&c. The future disputes between them are to be settled by the agent of the Seyed. They promise to discontinue the system of enticing and catching each other's people; they will put no difficulties in the way of the Seyed's project of a road to the coast ; the flag of the Seyed is to be erected at M.jari, at Mchichira, and at the town of Mawa. Arrangements were also made as to the return of runaways from Matola to Mkunla, and the giving up of a man whom Matola has in custody. 
"We stopped with the Arabs on a little sandbank in the middle of the river, where we built ourselves the usual grass huts. The Maviti had their camp some distance farther off, but came nearer to us on the Sunday night to be ready for the conference in the morning. I had visited them on the Sunday afternoon and found them looking very gay in their coats of skin, with their bright spears, \&c., \&c.

"I got a capital Makua congregation on the Sunday, a not very satisfactory interpreter, but they were all reverent, and seemed attentive. In the middle of the night they came to us, however, and said they would run away, they were afraid ; a little "moral suasion" reassured them, and they came well up to the scratch.

"The Arabs had some of our Mohammedan tracts, which they certainly studied : we talked them over together.

"We had some very wild Maviti war-dances on the conclusion of the business; their get-up is certainly very savage.

"I was glad to have an opportunity of making friends with Mawa, the greatest Makua chief of these parts. On my return journey I spent the last night at his village, and was well received."

Up to the present date, be it said, this treaty has been loyally observed.

In March I879 Mr. Maples came down to Zanzibar with eighteen candidates for confirmation, and the Makua chieftain, Matola, came with him also to beg from the Bishop a resident missionary. Of his own accord this chief, before he left, asked for a method of calculation by which he might be able to observe the Sunday's rest as it occurred ; and finding, that in accordance with the system of the Bishop, which affords a complete change of air to his European missionaries once every four years, Mr. Maples was going to England, he said :"Till you come back to us we have no one to teach us about God and Jesus Christ." For Mr. Clarke, on Mr. Maples' departure, had to withdraw from Newala to take charge of Masasi.

Mr. Johnson returned to Masasi in May 1879, taking with him over fifty freed men and women from Mbweni, besides 
a flock of sheep, a few oxen, and some fowls. With his wonted energy he was soon immersed in work of all kinds.

On December 3rd, I879, the Rev. A. Goldfinch and the Rev. John Swedi arrived at Masasi after a quick journey of eight days from Lindi, and brought with them several women and children.

Mr. Goldfinch thus records his impressions of the place:- "I was delighted with the grandeur of the scene as we came round the base of the mountains ; a more pleasant spot could scarcely have been chosen for our settlement. At the sound of our guns people came thronging out in all directions. As we went up the street such numbers of smiling happy-looking men and women came eagerly running to shake hands and exchange 'jumbos,' that we were puzzled to know where they all came from. At last, on nearing the house, I met Mr. Johnson and Mr. Clarke. The latter looked remarkably well, the former was pale and thin, but gave a good account of himself.

"They have built three new houses quite recently, and a bargain is being struck for some more land at a cheap rate. All our own buildings, being of bamboo without mud, are particularly light and airy-looking; privacy is out of the question, as every wall can be seen through, but what we lose in that way we gain in coolness.

"All the fruit-trees look remarkably healthy, and some of the bananas and pawpaws are bearing fruit. The English garden too has some promising crops of vegetables shooting up. There is quite a large flock of sheep-sixty-four, I thinkand we shall soon be able to eat fresh meat every week.

"The church seems to me rather too small for our needs, judging by yesterday morning's attendance. I trust it will be found necessary to enlarge it ere long. The services are hearty, wonderfully so, considering that so many of the congregation, being adults, are not able to read.

"I expect that one of my duties will be the charge of a new school in a neighbouring village, where there are numbers of children. The boys in out-of-school hours are doing some really useful work.

"The carpenters have made numbers of big, rough, but really 
strong bedsteads, some useful ladders, \&c., and are now making some chairs. The smiths are actually making an iron railing to go round the churchyard, and the lengths that are finished do them credit."

Later news tells of the expansion of work at Masasi, notably the opening of a new school in a neighbouring village under the charge of the Rev. John Swedi.

Of the future operations in this district the Bishop thus writes:- " We are in all our mainland stations between two enemies, the heathenism of the interior and the Mohammedanism of the coast, and these two are ready enough upon occasion to join hands against us. If, therefore, we can find the great point of communication between the coast and the interior, we mean to put a force there to bar the progress of the coast enemy. This is what has been done with great effect in our Mambara mission at Umba. On the Masasi line a somewhat similar post offers itself at Abdullah Pera's. Nothing has been done yet for the Mweras, who have a fine country, very accessible from the coast, and are untouched by any propaganda or any civilisation.

"We should not be led away by the desire to get all at once a long way into the interior; it involves enormous difficulties, and leaves Mohammedanism a free track behind it. I am not in favour of the scheme of making many small stations. I would rather have a compact station made as comfortable as possible, in a plain way, in food and lodging, and the ordinary details of life. All this is more likely to be attained in a well-ordered central station than in a small location. Many men want change, and for this a six months' stay at an out-station, varied by a month at the chief place, would often serve well. It is very desirable that more than one man should know something about the people at each place, and be known, more or less, to them; occasional changes of men are therefore a gain to all. This is why I should wish to see the station at Masasi enlarged and improved in every possible way.

"I should like to see permanent sub-stations at Abdullah Pera's, Machemba's, Mayeye, and Newala, each of them occupied by a man from Masasi, but not always by the same 
man, and, as soon as possible, a native catechist and schoolmaster put in charge, and the European to spend a week from time to time with him, as an evangelist rather than a pastor. As our men increase in number, and as our native catechists improve, it would be easy to enlarge our operations, and almost immediately evangelistic tours might be made among the Mweras to the north, and among the Yaos on the west, as far as the Lake itself.

"In these journeys endeavour should be made to bring back to Masasi for definite instruction, not boys, but young men, and, after awhile, their wives with them. Boy-teaching is eminently unsatisfactory in its ordinary results. Youths and adults are much better worth the labour of instructing. By these means chapels may be built, and public worship, in some form, maintained over a much larger extent than European work purely could hope to reach to.

"Of course there are other places opening to us. Thus the proposed Uzaramo mission might probably enough extend itself in a south-westerly direction, along the line of the proposed road to the Lake and Mr. Thompson's explorations. The Ubena people seem to be a fine race, and on the high plateau near the Lake (Nyassa), and onward, are many others -some, I hear, very hospitable, and neat and orderly in their ways. All these in time we may hope to reach; but we must not beat out our gold too thin, and it is to the work of the young men of the land itself that we must look for permanent progress."

But though the Bishop would not be led away by the desire to get all at once a long way into the interior, when it appeared that time and opportunity favoured the advance, he did not object to Mr. Johnson making an effort to extend his work to $M$ wemba, the capital of the Yao tribe, which lies nearly $25^{\circ}$ miles beyond Masasi, and not far from Lake Nyassa. The return of Mr. Maples to Masasi, after a visit to England, with a considerable party of clergymen and lay helpers, enabled Mr. Johnson to make this effort. So, taking with him five freed men, and two lads who had been educated at Zanzibar and emnloyed as sub-teachers at Masasi, he set out on his long- 
contemplated journey to Mwemba, Mataka's town, which he reached on All Saints' Day, I880. In his letter to the Bishop concerning his journey and his first experience at Mwemba, Mr. Johnson says:- "We spent a long time getting here, stopping ten whole days at various places. These were, however, I hope, profitably employed in becoming acquainted with the country and the people.

"Close to this I halted two days, and have come to know several that I may now regard as members of my charge.

"I spent this morning at Mataka's baraza. It is not on an imposing scale, but he seems to be a sensible man, and not to aim at show. (This man, be it said, was heir-apparent at the time of Bishop Steere's visit.) He came out quite the coastman in his dress, and was very civil.

"He soon had a house ready for us, and sent a goat, milk, pombe, and a little sugar (as a present). Abdullah took him a chief's cap and a joho (a long Arab coat), which we brought, and told him what we wanted. His answer was very favourable.

"I. He would send me some youths to cook for me.

"2. I might preach to the people at all times.

" 3 . On Sundays he would summon the people to a service in the baraza.

"4. He would give me porters to go down to Masasi, for whom he would answer.

"I have sent down to Mr. Mapies tor some sheep and money, and about seven loads of goods, which will, I think, carry us through the rainy season.

"I have also written to the European in charge of the Scotch mission at Livingstonia (on the Lake Nyassa), as they say that Lutonde, a place near Mponda's, is but five days from this by land.

"It is of no use to speak over-confidently, but I hope to get some sort of a beginning at Mtaliki's, Mpelemlie's, and Kandulu's, all which places could be covered by a ten days' circuit.

"The Gwangwera have been marauding here in great force, and Mataka and his people suffered from them severely.

"There is a great deal of slave-trading going on here. I 
have sent some notes of it to Dr. Kirk, but I feel that here I am sent to the slaves, and hope that Christianity will root it out, especially if external pressure could root out the villanous Kilwa agents and the women they bring."

Later on he says:- "I held a service at Mataka's baraza to-day. It is a great day with them in honour of the Mataka who preceded this one. Mataka killed an ox and some goats. I was glad to get a piece of the former, as it is a long time since I had tasted beef. At 9 A.M. I went with Abdullah to Mataka's baraza; a large number of people were assembled, and after a little waiting, during which an official made sallies to drive away the little boys who ventured to come too close to stare at me, Mataka came out. We had already had a chat together. He speaks Swahili-the French of the coastfluently. He listened attentively, and I think grasped the great news of our Lord's resurrection from the dead.

"People swarm outside the house I am living in, and from time to time I go out and speak to them. I have already got a few boys to live with me, and have begun to teach them the A B C.

"There are some 3000 houses in the place, and many villages near. Dr. Livingstone counted 5000 in the old town. Perhaps this is owing to war, perhaps also to the speed with which this place has been run up, as they were only driven here by the Gwangwara last year. I shall thus have plenty of scope for my preaching."

Subsequent information from Mr. Johnson told of his efforts to bring home to the Yaos the message of salvation, and of his personal experience at Mwemba. As he was unaided by the presence of any European, in the midst of a multitude of the heathens, always hearing of wars and rumours of wars, and not unreasonably expecting that the Gwangwara, the dreaded foe of the Yaos, would again attack them, his position was one to try the faith and the patience as well as the courage of the strongest. But he was moved by none of these things, and went on day by day with his work, forming classes for children, and for men and women, endeavouring to gain more and more the confidence and attention of Mataka, and making 
provision for his own wants. This continued for some time, when he became almost incapacitated by ulcerated hands, and he determined to go to Livingstonia to get, if possible, a cure for them. He says of the result of his experience there, writing from Mwemba on May 25th, I88I :- "Dr. and Mrs. Lawes, not to mention junior members of the mission, set me up again, and sent me back here rejoicing some two months ago. I was enabled then to send Barnabas Mwatuka, my fellow-Christian here, to get more cloth from the Livingstonia Company, and to try to get sheep from the Maviti beyond. I wrote fully by him to the Bishop and others, and shall be interested to learn how letters go via the Zambesi. We are now daily expecting his return. Meanwhile four men have come from Masasihow welcome! News of home, but even now six months old, and the last coast letter is dated January $20 t h$. They bring delightful things, parcels and letters, and good things for food, but no stores for purchase.

"Mataka has promised to build a church, and looking at all circumstances I think it is right to wait to build till he takes an active part. From my letters it may appear that he has delayed till there is no assurance that he will do anything, but it is the fact that till now people have done nothing for lack of food; and since they have got in some of the harvest, Mataka has been seriously ill, and has not yet recovered. He has marked out a place quite in the middle of the town, and at the worst I can build there myself."

With reference to his daily work he says :- "First as to most days, there are entries of sick people, with rheumatism, head and stomach aches, sore places, chiefly sore eyes, \&c., \&c. School every day twice. There are three boys getting on slowly with reading and writing, but many picking up something of counting, catechism, and scripture, and such facts of geography as that 'the coast is not a town about parallel to Mwemba, where all the Wazungu (white men), \&c., live together.' The school is of course carried on at great disadvantage; nobody here does the same thing two days running, and so no boy comes twice in three days. Then we have nowhere to read but the house, and twenty boys in the tiny 
room soon elicit cries of discomfort, and the interruptions are countless. The men's class is on Wednesdays and the women's on Fridays. Both are well attended, though the attendance varies within certain limits. One man, however, has come every time without missing, and on Sundays also. This attendance is the more cheering, as Mkumlumba and most of his following have been away at Nyassa. Mkumlumba was appointed by Mataka to be my host, and at first I feared the effect of his absence ; but probably, as with most other things, it has turned out to the furtherance, and not to the hindrance of the work. In holy week I marked the time as best I might by readings at the hours, in the baraza, on the events of the day. I trust many carried away something. At least many know that faith in the Son of God is the way of following God.

"Sunday attendance has been increasing. Yesterday there were at least seventy adults, and twice as many children. This was more than usual. A big plate is beaten to tell the people the day before, but how sadly we want a church (the people can't get into the gathering place) and a big bell. Men from the coast often expatiate on the charms of Masasi, and by no means the least on the bell.

"It was a real treat outwardly, as well as, I trust, in spirit, to have three fellow-Christians from Masasi to finish the services yesterday, i.e., the regular psalms, the Te Deum, the Creed, and some of the prayers. The boys know the rest well enough to respond, but singing I do not attempt. Certainly the service is not too long, and the adults are pleased with the boys' responses; but singing is one of the multifarious things for which I long for a fellow-communicant, not to dwell on what is implied in the very name.

"Need I dwell on the sore want of a fellow-Christian to share in spiritual life, as well as to help outside! With such an one, I think, we might preach the Word in a large tract of country, and yet keep up an energetic work here-care for the sick, welcome, and so teach, strangers that pass here, have a good school, regular classes and services, and get through much outdoor work. 
"Please, plead with English churchmen to send freely, and fight here for freedom through our Lord and Master."

With the foregoing appeal this narrative of the Universities' Mission fittingly closes, but a few more words are needful to describe other ventures of faith which have been made during the past twenty years in Central Africa, i.e., since the Universities' Mission commenced its operations.

r. The Church Missionary Society has greatly enlarged the field of its operations. Thirty-seven years ago it planted a mission at Mombasa, a coast town which lies $\mathrm{r} 20$ miles north of Zanzibar, of which Dr. Krapf and Mr. Rebman were the first missionaries. By their many journeys and constant preaching they were able to obtain considerable information about the country and its inhabitants for several hundreds of miles into the interior, and to make the object of the missionary more or less familiar to all the leading tribes; and when Bishop Tozer visited Mr. Rebman, who had for twenty-five years borne the burden of the work at Mombasa, he found him surrounded by a small but earnest body of native believers belonging to the Wanika tribe, and who were the fruit of his life's work. But a freed slave settlement, called Frere Town, was established in 1875 at Mombasa, where there are now nearly 500 freed slaves who are more or less under religious instruction.

In 1876 the Society responded to the appeal of Mr. H. W. Stanley, the African traveller, to send missionaries to Uganda, a region lying on the north-west of the great Lake, the Victoria Nyanza, of which when the Universities' Mission was projected little or nothing was really known in England, and it now has stations not only at the town of Mtesa, the king of Uganda, but also at Mpwapa, Rubâga, Uyui, and Mamboia.

2. In 1862 the United Methodist Free Churches of England established a mission at Ribe, which is not far from Mombasa, and only a few miles from the sea.

3. Within the last ten years the London Missionary Society has taken the region of Lake Tanganyika, which lies 700 miles inland, as its sphere of labour.

4. When the news of Dr. Livingstone's death reached England, Scotland felt anxious to do honour to his name, and the 
Free Kirk decided to give effect to this feeling by establishing a mission in the neighbourhood of the Lake Nyassa, which should bear his name; and the Established Kirk also resolved to send a mission to the Shire Highlands, to be called Blantyre, after the place where he was born. In the choice of these localities the promoters of these missions were influenced by the representations of Dr. Stewart, who visited the country in which the Universities' Mission was first placed in 1862 , and Mr. E. Y. Young, of the Royal Navy, who was for some time in charge of Dr. Livingstone's ship, the Pioneer, and who commanded the Livingstone Search Expedition. Both these gentlemen had personal experience and considerable knowledge of the country vacated by the Universities' Mission, and they joined in recommending it as most suitable for missionary purposes. The experience of these missions has shown that this recommendation was sound; and at Livingstonia on the Lake Nyassa, and at Blantyre on the Shire Highlands, in the Kujireka district, which adjoins that of Magomera, there are now more than twenty missionaries, some of whom have their wives and children with them.

It may not be too much to say that these Scotch missions have been greatly aided by what was done by the Universities' Mission. When Mr. Young first revisited the country in which that Mission had worked, he found at Chibisa's and elsewhere a cordial welcome from the people, who were ready to do all he required of them. Everywhere indeed a grateful memory of the missionaries was found to exist, and the freed slaves and others that became adherents of the Mission had kept together and in union with the Makololo, who are now the chiefs of the greater part of the Lower Shire valley, were safe from re-enslavement. When Mr. Young in 1875 went forth to find a suitable locality for the Livingstonia and Blantyre missions, and took with him a little steam-ship for the navigation of the Upper Shire and the Lake Nyassa, he received aid from the people in the neighbourhood of Chibisa's, without which his venture must have failed. At the Murchison Cataracts the Ilala, the steam-vessel, was taken to pieces; Ramakukan, Malouri, and the rest of the Makololo, offered to give any help 
in their power ; Chimlolo and others of our old friends placed themselves heartily at Mr. Young's service, and he thus records the result:- "Let this ever stand to the African's credit, that eight hundred of these men worked, and worked desperately for us, free as air to come and go as they pleased, over a road which furnished at almost every yard an excuse for an accident, or a hiding-place for thief or deserter, but yet at the end of the sixty miles we had everything delivered up to us unmolested, untampered with and unhurt, and every man merry and content with his well-earned wages."

5. The Roman Catholics now have missions at Bagamoyo, Ujiji, and at Uganda.

6. The Société des Missions Evangéliques, of Paris, have begun to occupy the Barotse Valley, which is the region about the head waters of the Zambesi, above the Victoria Falls, and about 1200 miles from the mouth of the river.

7. Another organisation now at work is the International Association for the Suppression of the Slave Trade and Opening of Central Africa, which was inaugurated in September 1876 at Brussels, under the presidency of the King of the Belgians.

Corresponding religious and philanthropic efforts are being made upon Central Africa from the west, and almost all such efforts have originated within the last twenty years.

The Universities' Mission was the first to attempt the conversion of the tribes of the interior of Central Africa, and when it was withdrawn from the Zambesi district some pronounced it the most conspicuous failure of modern missionary enterprises, and others declared that any attempt to work far away from the coast must fail. Contrast the efforts that are now being made to Christianise Central Africa with those of twenty years ago, and I think that there are few who would call the Universities' Mission a failure, either in the results which it has itself gained, or in the influence which it has had in causing other ventures to be made. No mission of modern times has been more sanctified by the death of its missionaries; in none has there been exhibited greater faith, greater patience, greater endurance of hardship, greater courage in the hour of danger, or greater examples of self-sacrifice for Christ's sake. 
Compared with the expectations that were raised in connection with the Mission before it left England, the results of twenty years' work may seem to some insignificantly small, but such expectations were not warranted by the history of any previous mission, for at no time has the church in her warfare against heathenism met with a speedy success unchecked by disappointment and seeming failure. Three hundred years passed away before Rome became even nominally Christian, and thirteen hundred years passed away before the whole of Europe was converted to Christ. To the men of this generation belongs the honour of being pioneers in the effort to evangelise Central Africa, and if many generations of men pass away before that effort is really successful, it will be only in accordance with the rate of progress which the church has made in all ages. But of this we may be sure, there is present with each struggling and suffering mission in Central Africa, and with each Christian missionary, the same divine power which smote to the dust the idols of Greece and Rome, and converted to the Cross of Christ the barbarous hordes of Northern Europe. 


\section{A SELECTION}

OF

\section{WELLS GARDNER, DARTON, \& CO.'S PUBLICATIONS.}

\section{THE BISHOP OF BEDFORD.}

By the Right Rev. W. Walsham How, D.D.

PASTOR IN PAROCHIÂ. Fcap. 8vo, cloth boards, 3s. $6 \mathrm{~d}$. With the Appendix. Cloth boards, red edges, 4s. 6त.; calf limp antique, Ios. 6d. Also morocco or calf plain, and best flexible morocco, red under gold edges. [Fifteenth Edition.

DAILY FAIIIY PRAYER. Fcap. 8vo, cloth boards, Is. $6 \mathrm{~d}$.

[Twelfth Edition.

A Sixpenny Edition, in large type, cloth boards, is now ready. This volume will be found most suitable for parochial distribution, and is the cheapest book of Family Prayers yet published.

HOLY COMMUNION. For those who need Encouragement.

6 d. per packet of 20 .

[145th Thousand. 
WORKS BY THE BISHOP OF BEDFORD-continued.

PLAIN WORDS. First Series. Sixty Short Sermons for the Poor, and for Family Reading. Fcap. 8vo, cloth, turned in, 2s. ; cloth boards, red edges, 2s. 6d. Large-type Edition, cloth boards, 3s. $6 \mathrm{c}$.

[Forty-ninth Edition.

PLAIN WORDS. Second Series. Short Sermons for the Sundays and Chief Holy-days of the Christian Year. Fcap. $8 \mathrm{vo}$, cloth, turned in, 2s. ; cloth boards, red edges, 2s. $5 \mathrm{~d}$. Large-type Edition, cloth boards, 3s. 6 d.

[Thirty-ninth Edition.

Vols. I. and II. in one vol., cloth boards, 4s. 6d.

PLAIN WORDS. Third Series. Forty Meditations with a View to the Deepening of the Spiritual Life. Fcap. 8vo, cloth limp, 2s. ; cloth boards, red edges, 2s. 6d. Large-type Edition, cloth boards, $3 \mathrm{~s} .6 \mathrm{~d}$.

[Sixternth Edition.

PLAIN WORDS. Fourth Series. Forty Readings for those who desire to Pray Better. Fcap. 8vo, cloth limp, turned in, 2s.; cloth boards, red edges, 2s. 6 d.

[Fifth Edition.

Vols. III. and IV. in one vol., cloth boards, 4s. 6d.

PLAIN WORDS, as Tracts. Series I.-III., in Large type, 2s. 6d. each Series.

A Selection from "Plain Words," in smaller type, Is. per packet, three kinds.

PLAIN WORDS TO CHILDREN. Crown 8vo, cloth, bevelled boards, 2s. 6 d. ; fcap. 8 vo, cloth limp, turned in, 2 .

[Third Eciition. 
WORKS BY THE BISHOP OF BEDFORD-continued.

PRAYERS FOR SCHOOLS. Royal 32mo, paper covers, $3^{\text {d. ; cloth, } 6 \text { d. }}$

PRIVATE IIFE AND MINISTRATIONS OF THE PARISH PRIEST. Royal 32mo, leather, 6d.

RESOLUTIONS FOR THOSE RECOVERING FROM SICKNESS. On Card, in red and black, 12 copies in packet, $6 \mathrm{~d}$.

REVISION OF THE RUBRICS. An Historical Survey of all that has been done since the issue of the Ritual Commission in $\mathbf{1 8 6 7 .}$ Demy 8 vo, $\mathbf{1 s}$.

SCRIPTURE READINGS. The Appendix to "Pastor in Parochiâ." Selected Passages for Reading to the Sick. Fcap. 8 vo, cloth boards, Is. $6 \mathrm{~d}$.

SEVEN LENTEN SERIIONS ON PSALM LI. Fcap. 8 vo, cloth limp, turned in, Is.

[Eleventh Edition.

SUGGESTIONS FOR OBSERVING THE DAY OF INTERCESSION. Id. ; 6s. per 100.

THE EVENING PSALTER POINTED FOR CHANTING. Oblong cloth limp, 6d.

TWENTY-FOUR PRACTICAL SERIMONS. Fcap. Svo, cloth limp, turned in, 2s. ; cloth boards, red ed_es, 2s. $6 \mathrm{~d}$.

[Tweljth Eaition.

TWO ADDRESSES ON HOLY MARRIAGE. Id. 
WORKS BY THE BISHOP OF BEDFORD-continued.

VESTRY PRAYERS WITH A CHOIR. On Card, in red and biack, $\mathbf{I d}$.

A PRAYER FOR THE PARISH. On Card, in red and black, Id.

A SERVICE for the ADMISSION of a CHORISTER. In red and black, $2 \mathrm{~d}$.

CANTICLES POINTED FOR CHANTINA, with Appropriate Chants. $4^{\text {to, }}$ paper covers, $\mathbf{r s .}$

BY THE REV. J. ERSKINE CLARKE, M.A.

Vicar of Battersea, Hon. Canon of Winchester.

COMMON-LIFE SERMONS. Fcap. 8vo, cloth limp, 2s.; cloth boards, 2s. $6 \mathrm{~d}$. [Sixth Thousand.

Edited by the Rev. J. Erskine Clarke, M.A.

CHILDREN OF THE OLD TESTAICENT. With numerous Full-page Illustrations. Royal 4to, paper boards, Is. 6d.; cloth gilt, 2s. $6 \mathrm{~d}$.

GOOD STORIES. The earlier numbers, consisting of I $80 \mathrm{Com}$ plete Stories, selected and edited by the Rev. J. ErSKInE Clakke, M.A. Illustrated, in an Ornamental Cover, 3d. each A List forwarded on application. 

SMITHSONIAN INSTITUTION LIBRARIES

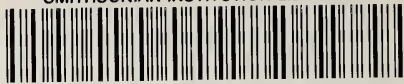

$3 \quad 908800756 \quad 3752$ 